\title{
Laila Meija
}

\section{ALKILREZORCĪNU, LIGNĀNU METABOLĪTI UN D VITAMINNS PRIEKŠDZIEDZERA VĒŽA PACIENTIEM}

Promocijas darbs medicīnas doktora zinātniskā grāda iegūšanai Specialitāte - internā medicīna

$$
\text { Rìga, } 2014
$$




\title{
ALKILREZORCĪNU, LIGNĀNU METABOLĪTI UN D VITAMINNS PRIEKŠDZIEDZERA VĒŽA PACIENTIEM
}

\author{
Promocijas darbs \\ medicīnas doktora zinātniskā grāda iegūšanai
}

Specialitāte - internā medicīna

Darba zinātniskie vadītāji:

Dr. med. profesors Aivars Lejnieks

Dr. med. asociētais profesors Vilnis Lietuvietis

Zinātniskais konsultants:

Dr. med. emeritētais profesors Herman Adlercreutz 


\begin{abstract}
ANOTĀCIJA
Uzturs ir nepieciešams visu cilvēka biolog̣isko procesu normālai funkcionēšanai. Pilnvērtīgs uzturs šūnu līmen̄̄ nodrošina visu organismu ar uzturvielām, kas nepieciešamas audu struktūras un funkcijas saglabāšanai. Turklāt uzturs ir viens no ietekmējamiem onkologiisko slimību riska faktoriem. Uzskata, ka ar uzturu var novērst trešdaļas vēžu veidošanos. Priekšdziedzera vēzis ir otra biežākā ļaundabīgā onkoloǵiskā slimība vīriešiem visā pasaulē. Latvijā tas ir pirmais biežākais vēzis un otrs biežākais nāves cēlonis starp visiem vēža veidiem vīriešiem. Augstā slimības prevalence un bieži lēnā attīstība padara priekšdziedzera vēzi par ḷoti piemērotu prevencijai. Par uzturu kā priekšdziedzera vēža risku ietekmējošo faktoru lika domāt zemā priekšdziedzera vēža incidence un prevalence Āzijas valstīs, kur protektīvo ietekmi saistīja ar fitoestrogēnu sojas produktu - iespējamo iedarbību. Rietumvalstīs galvenie fitoestrogēnu avoti ir lignāni. Ziemel̦valstīs galvenais lignānu avots ir rudzu maize, kas ir arī bagāts šķiedrvielu avots. Šķiedrvielas maizē saistītas ar daudzām biologiski aktīvām vielām, tostarp lignāniem un alkilrezorcīniem. Cits iespējamais faktors, kas var ietekmēt priekšdziedzera vēža attīstību, ir D vitamīns, kam, iespējams, piemīt ne tikai imunitāti modulējošā, bet arī antikancerogēnā aktivitāte.
\end{abstract}

Pētījuma mērḳis bija izpētīt, kurš alkilrezorcīnu metabolīts ir vispiemērotākais, lai novērtētu rudzu maizes un rudzu maizes šķiedrvielu daudzumu uzturā, kā arī izvērtēt alkilrezorcīnu un lignānu metabolītu saistību ar priekšdziedzera vēža risku. Otrs mērķis bija novērtēt pilngraudu rudzu maizes iespējamo ietekmi uz priekšdziedzera vēža progresēšanu. Cits mērķis bija novērtēt $\mathrm{D}$ vitamīna iespējamo saistību ar priekšdziedzera vēža risku.

Lai izpildītu izvirzītos mērķus, noteicām potenciāli biolog̣iski aktīvo vielu alkilrezorcīnu un lignānu - daudzumu Latvijas maizes veidos, novērtējām uzņemto uzturu, tostarp maizes, rudzu maizes, šķiedrvielu, alkilrezorcīnu, lignānu un D vitamīna daudzumu uzturā, kā arī alkilrezorcīnu metabolītu (DHPPA - 3-(3,5-dihidroksifenil) propānskābes un DHBA - 3,5-dihidroksibenzoskābes) un lignānu metabolīta (ENL enterolaktona) daudzumu asins plazmā, 12 stundu dienas un 12 stundu nakts urīnā un D vitamīna līmeni serumā priekšdziedzera vēža un kontroles grupas pacientiem. Lai novērtētu rudzu maizes iespējamo ietekmi uz priekšdziedzera vēža progresēšanu, nozīmējām rudzu maizes lietošanu un veicām izmeklējumus pirms un pēc rudzu maizes 
iekļaušanas uzturā - noteicām priekšdziedzera specifisko antigēnu (PSA), alkilrezorcīnu un lignānu metabolītus plazmā, dzimumhormonus, kāar ari tika veikti morfologiskie izmeklējumi.

Mūsu pētījuma rezultāti parādīja, ka alkilrezorcīnu un lignānu daudzums Latvijas sēklu un rudzu maizēe, kā arī uzturā kopumā ir augsts. Alkilrezorcīnu koncentrāciju maizē var izmantot par marķieri kliju un šķiedrvielu daudzumam maizē. Arī uzturā alkilrezorcīnu un lignānu daudzums ir augsts. Galvenie lignānu avoti uzturā bija sēklu un rudzu maize. Nebija atšķirību uzn̦emtā uztura datos, tostarp maizes daudzumā un veidā, kā arī alkilrezorcīnu un lignānu daudzumā starp priekšdziedzera vēža un kontroles grupas vīriešiem. Piemērotākais biomarķieris rudzu maizes un rudzu šķiedrvielu daudzuma uzturā novērtēšanai ir DHPPA 12 stundu nakts urīnā. Alkilrezorcīnu metabolītu koncentrācijas plazmā un urīnā saistība ar uztura datiem atšķīrās abās pētījuma grupās. Iespējamais atšķirības iemesls ir kavēts alkilrezorcīnu metabolisms priekšdziedzera vēža pacientiem. Analizējot lignānu metabolītu ENL, konstatējām, ka tā koncentrācija biologiiskajos šķidrumos atspoguḷo lignānu daudzumu uzturā tikai intervences pētījuma apstākḷos.

Konstatējām, ka rudzu maize, iespējams, kavē priekšdziedzera vēža progresēšanu. Potenciālie darbības mehānismi - dzimumhormonu saistošā globulīna, enterolaktona un alkilrezorcīnu metabolītu koncentrācijas palielināšanās plazmā, kā rezultātā pazeminājās PSA un tika novērota apoptozes rādītāju pieauguma tendence. Jāturpina pētījumi ar lielāku dalībnieku skaitu, tie jāveic ilgākā laika periodā, un jāizmanto rudzu maize ar vēl augstāku rudzu šķiedrvielu daudzumu.

Analizējot D vitamīna līmeni, konstatējām, ka D vitamīna deficìts un/vai nepietiekamība ir plaši izplatīta priekšdziedzera vēža grupā un kontroles grupas vīriešiem pēc 45 gadu vecuma. Atšķirības D vitamīna koncentrācijā serumā starp grupām netika konstatētas. Ar uzturu netiek nodrošināts nepieciešamais D vitamīna daudzums abās pētījuma grupās. Lai sasniegtu vēlamo D vitamīna koncentrāciju serumā un lai izvērtētu D vitamīna iespējamo protektīvo efektu priekšdziedzera vēža prevencijā, ieteicams lietot D vitamīna neaktīvās formas preparātus un uzturā vairāk lietot zivis.

Iegūtie rezultāti izmantojami kā pamats turpmākiem padziḷinātiem pētījumiem par pilngraudu produktu un D vitamīna lomu priekšdziedzera vēža prevencijā. 


\section{SUMMARY}

Food is essential in all biological processes of the human body. Food provides human body with all nutrients needed to maintain its tissue structure and run its functions. Furthermore, food is an important factor affecting the course of oncological disease one can change. There is some evidence showing that one third of all cancers can be prevented. Prostate cancer is the second most common cancer in men worldwide, while it is the first most common cancer and second leading cause of death from cancer in Latvian men. The high prevalence and often slow progression of prostate cancer makes it suitable for prevention. The low incidence and prevalence of prostate cancer in Asia suggests that nutrition may play a role in the progression of prostate cancer. It has been suggested that the protective effect found in Asia may be due to soy products rich in phytoestrogens. Lignans are the most important phytoestrogen sources in the Western countries. In North Europe, rye bread is the main source of lignans, which is also rich in fiber. Bread 'fiber complex' is linked to many bioactive compounds, including lignans and alkylresorcinols. An insufficient concentration of vitamin D is another possible risk factor of prostate cancer because vitamin D may have not only immunomodulating, but also anticarcinogenic effects.

The objective of this thesis was to find out alkylresorcinol metabolites most suitable to estimate rye bread and rye bread fiber intake and also to evaluate relationships between metabolites of alkylresorcinols and lignans and their links to the risk of prostate cancer. The second objective was to assess any possible effect of whole grain rye bread on the progression of prostate cancer. The third objective of the thesis was to evaluate any possible links between vitamin $\mathrm{D}$ and the risk of prostate cancer.

We detected alkylresorcinols and lignans, bioactive compounds, in Latvian breads while carrying out dietary assessment. This included intake of bread, rye bread, fiber, alkylresorcinols, lignans and vitamin D, concentrations of alkylresorcinols metabolites (DHPPA-3-(3,5-dihydroxyphenyl)-1-propanoic acid and DHBA 3,5-dihydroxy-benzoic acid), and lignan metabolite (ENL - enterolactone) in plasma, 12-h day and 12-h night urine and serum concentration of vitamin D in prostate cancer in the group of PC patients and the control group. Using dietary intervention of rye bread, we investigated the effects on prostate cancer progression by assessing Prostate Specific Antigen (PSA), metabolites of alkylresorcinols and lignans in plasma, sex hormones and morphological examination before and after the intervention. 
The results show that alkylresorcinol and fiber concentration are high in Latvian breads. Alkylresorcinols` concentration in bread may be used as a marker of bran and fiber amount in bread. Alkylresorcinol and lignan intake were also found to be high. Seed and rye breads were found to be the main dietary sources of lignans. There was no difference found between the prostate cancer and control groups in the dietary intake data, including bread quantity and bread types, alkylresorcinol and lignan intake. DHPPA in $12 \mathrm{~h}$ overnight urine may be the most suitable alkylresorcinol metabolite to estimate the intake of rye bread and rye fiber. Differences were found between the prostate cancer and the control group regarding associations between alkylresorcinol metabolite concentrations in plasma, urine and food intake data, possibly due to a delay in the metabolism of alkylresorcinols in the prostate cancer group. It was found that enterolactone, a lignan metabolite, is linked to the intake of lignans only under the conditions of intervention.

The results of the intervention study reveal a possible delay in the progression of prostate cancer via elevated concentration of sex hormone binding globulin, enterolactone and alkyresorcinols metabolites in the group of prostate cancer, which resulted in lower rates of PSA and presumably increased apoptosis. We suggest the future studies on this subject with longer time periods covered, with larger numbers of participants and the use of bread with higher concentrations of rye fiber.

We found that vitamin D deficiency and/or insufficiency is highly prevalent in the group of prostate cancer and in men aged over 45 in the control group. There were no differences found between the groups in the concentration of vitamin D in serum. Vitamin D dietary intake was found to be insufficient in both study groups. To assess possible vitamin D protective effect in the prevention of prostate cancer, it is advisable to reach higher concentrations of the vitamin using vitamin D supplementation, also a higher amount of fish in the diet. 


\section{SATURS}

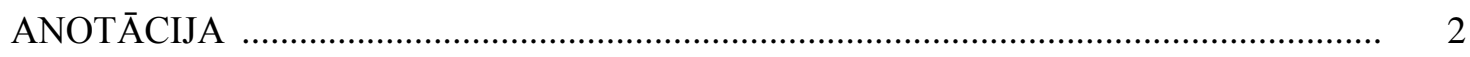

DARBĀ IZMANTOTIE SAĪSINĀJUMI .................................................................. 8

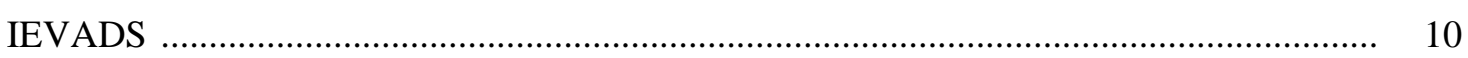

Zinātniskā darba aktualitāte

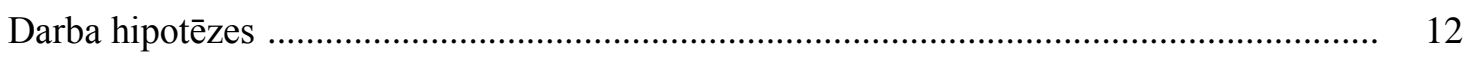

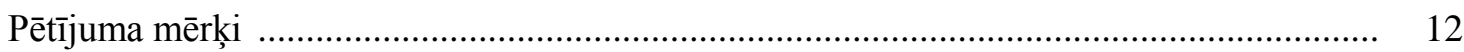

Uzdevumi mērķa sasniegšanai ................................................................................. 13

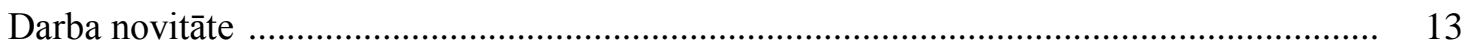

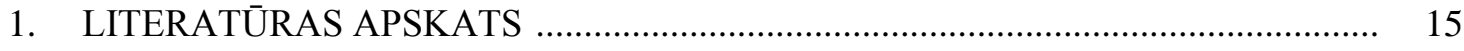

1.1. Uzturs un vēzis ............................................................................................ 15

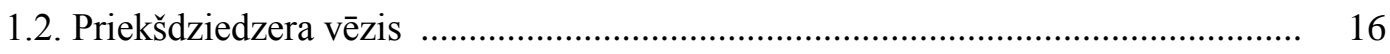

1.3. Ar uzturu saistîtie priekšdziedzera vēža attīstību ietekmējošie faktori ................ 23

1.3.1. Fitoestrogēni .................................................................................. 23

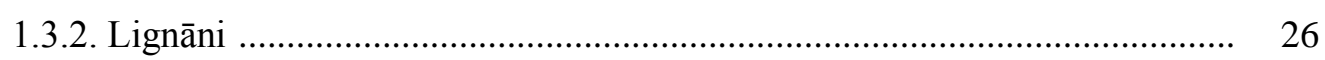

1.3.3 Pilngraudu produkti, rudzu maize un šķiedrvielas ..................................... 37

1.3.4. Alkilrezorcīni - pilngraudu marķieri ....................................................... 40

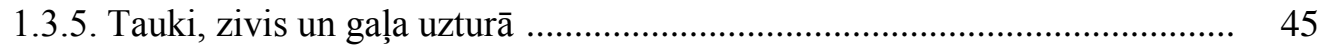

1.3.6. Sakņaugi un citi dārzeņi uzturā ................................................................. 48

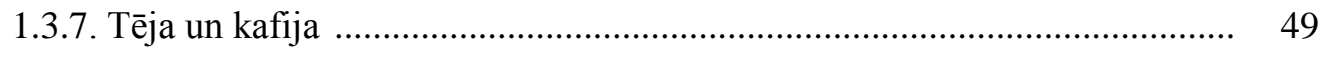

1.3.8. Piena produkti un kalcijs ..................................................................... 50

1.4. Aptaukošanās un priekšdziedzera vēzis ..................................................... 50

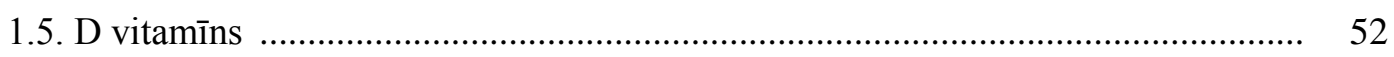

1.6. Citi iespējamie priekšdziedzera vēzi ietekmējošie faktori .................................. 61

1.7. PSA skrīninga ieviešanas ietekme uz uztura pētìjumu datu interpretāciju ............ 62

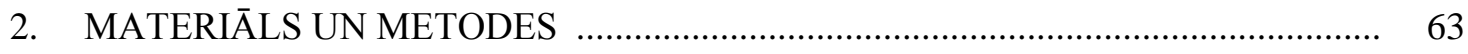

2.1. Pētījuma dalībnieki un dizains ....................................................................... 63

2.1.1. Gadījumu kontroles pētijuma dizains ............................................................... 63

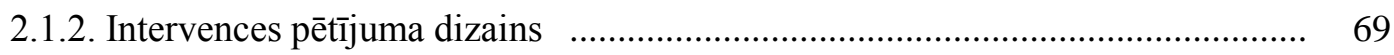

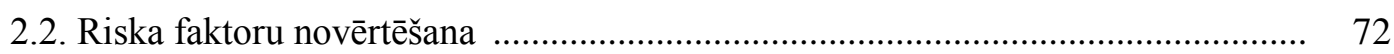

2.3. Uzņemtā uztura un uzturvielu novērtēšana ...................................................... 72

2.4. Lignānu un alkilrezorcīnu noteikšana dažādos maizes veidos ............................ 75

2.5. Laboratoriskie izmeklējumi ................................................................................ 76

2.6. Morfologiskā izmeklēšana _............................................................................. 78

2.7. Datu statistiskā analīze ................................................................................... 79 


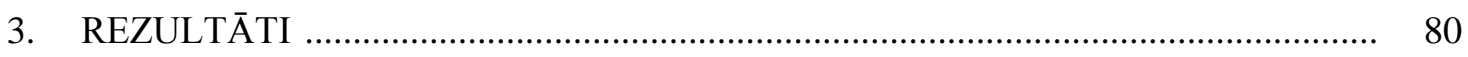

3.1. Alkilrezorcīni un lignāni Latvijas maizē ............................................................ 80

3.2. Pētījuma dalībnieku Kopējās grupas vispārīgs raksturojums ............................. 83

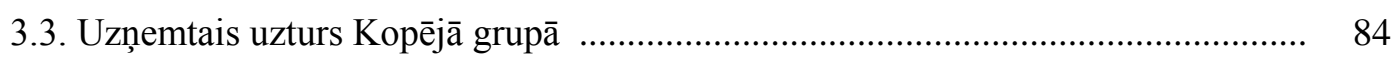

3.3.1. Uztura vispārējais raksturojums …..................................................... 84

3.3.2. Alkilrezorcīni uzturā Kopējā grupā ...................................................... 89

3.3.3. Lignāni uzturā Kopējā grupā ............................................................... 90

3.4. Laboratoriskie izmeklējumi .......................................................................... 93

3.5. Korelācija starp uztura parametriem un alkilrezorcīnu un lignānu metabolītu koncentrāciju asins plazmā un urīnā Izmeklējumu grupā ..................................... 94

3.6. Intervences pētījums „Pilngraudu rudzu maizes ietekme uz priekšdziedzera vēža progresēěanu" ............................................................... 108

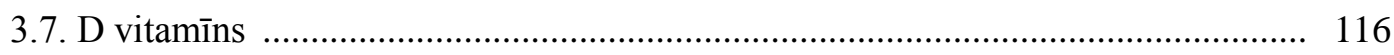

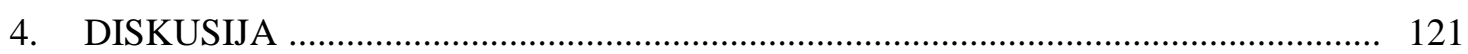

4.1. Alkilrezorcīni un lignāni Latvijas maizē ............................................................. 121

4.2. Pêtījuma dalībnieku uzņemtā uztura raksturojums .............................................. 124

4.3. Alkilrezorcīni un lignāni uzturā ...................................................................... 125

4.4. Alkilrezorcīnu metabolīti ............................................................................ 130

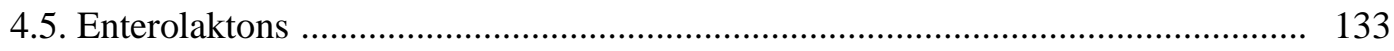

4.6. Rudzu maizes lietošana PV pacientu uzturā ..................................................... 136

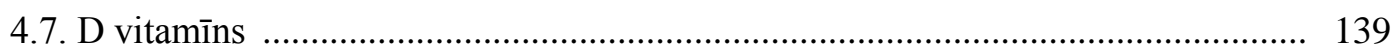

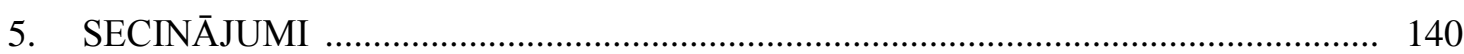

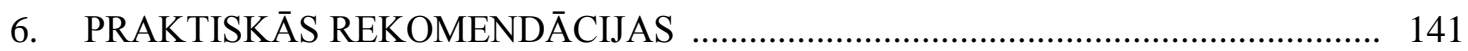

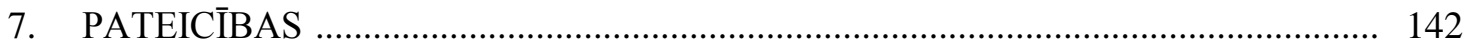

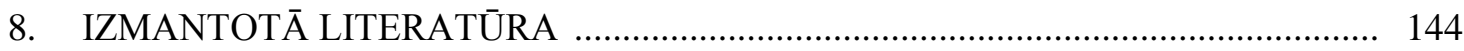

9. PUBLIKĀCIJAS PAR PROMOCIJAS DARBA TĒMU …....................................... 159

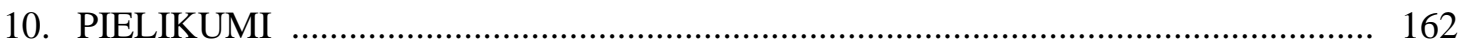




\section{DARBĀ LIETOTIE SAĪSINĀJUMI}

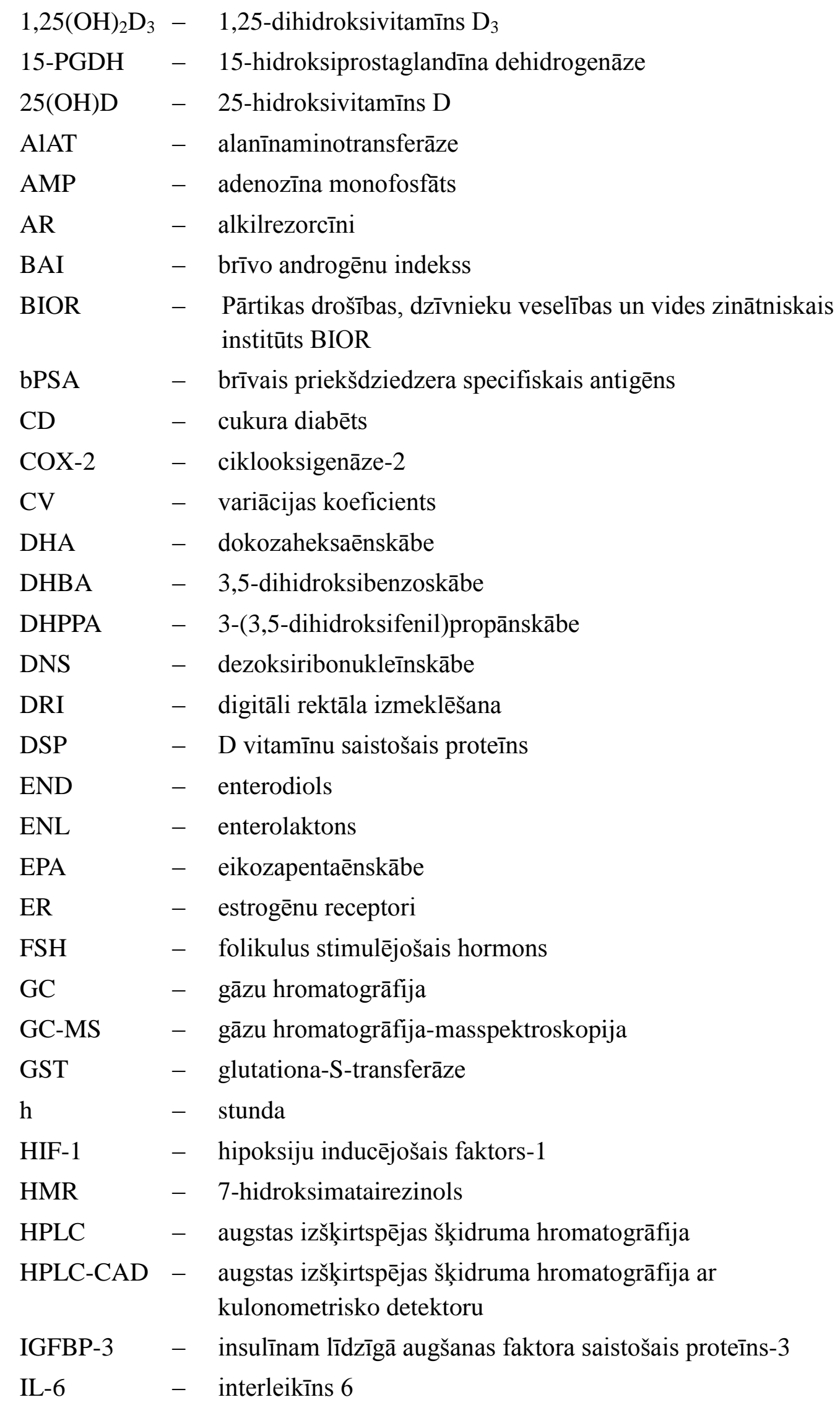




$$
\begin{aligned}
& \text { IL-8 } \quad-\text { interleikīns } 8 \\
& \text { LAR - laricirezinols } \\
& \text { LC-MS - šķidruma hromatogrāfija-masspektrometrija } \\
& \text { LH - luteinizējošais hormons } \\
& \text { LPH - labdabīga priekšdziedzera hiperplāzija } \\
& \text { MAT } \quad-\text { matairezinols } \\
& \text { MED } \quad-\text { mediorezinols } \\
& \text { MKP-5 - mitogēnu aktivētā proteīnkināze-fosfatāze-5 } \\
& \text { MMP-9 - proteolītisko enzīmu matrices metālproteināze-9 } \\
& \text { MNTS - mononepiesātinātās taukskābes } \\
& \text { NADPH - nikotīnamīda adenīna dinukleotīda fosfăta oksidāze } \\
& \mathrm{NF \kappa B} \quad-\text { nukleārais faktors } \kappa \mathrm{B} \\
& \text { NMS } \quad-\text { Nacionālais medicīnas serviss } \\
& \text { nn } \quad-\text { nav nosakāms } \\
& \text { PG } \quad-\text { prostaglandīni } \\
& \text { PIN } \quad-\text { pinorezinols } \\
& \text { PNTS - polinepiesātinātās taukskābes } \\
& \text { PSA } \quad-\text { priekšdziedzera specifiskais antigēns } \\
& \text { PTH - parathormons } \\
& \text { PV } \quad-\text { priekšdziedzera vēzis } \\
& \text { SD - standartnovirze } \\
& \text { SECO - sekoizolaricirezinols } \\
& \text { SERM - selektīvie estrogēnu receptoru modulatori } \\
& \text { SHBG - dzimumhormonu saistošais globulīns } \\
& \text { SKA } \quad-\text { starpkvartiļu amplitūda } \\
& \text { SPKC - Slimību profilakses un kontroles centrs } \\
& \text { SV } \quad-\text { starptautiskās vienības } \\
& \text { SYR } \quad-\text { siringarezinols } \\
& \mathrm{T}^{1 / 2} \quad-\text { eliminācijas pusperiods } \\
& \text { TNF- } \alpha \quad-\text { audzēja nekrozes faktors } \alpha \\
& \text { TRUS _ - transrektālā ultrasonoskopija } \\
& \text { UV-B - ultravioletais starojums B } \\
& \text { VEGF - asinsvadu endotēlija augšanas faktors }
\end{aligned}
$$




\section{IEVADS}

\section{Zinātniskā darba aktualitāte}

Pēdējos gadu desmitos pieaug zinātniskā interese par uztura saistību ar veselību un īpaši par bioloǵiski aktīvajām vielām augos, kam ir gan nozīme veselības saglabāšanā, gan arī iespējama ietekme uz slimības norisi. Līdz ar to satuvinās medicīna un uzturzinātne. Augi, kas satur fiziologíski aktīvas vielas, vienlaikus ir gan uztura sastāvdaḷa, gan zāles. Turklāt tiek radīti jauni funkcionālie produkti, kas ir pārtikas produkti, kuru sastāvs tiek pārveidots, lai pastiprinātu kādu protektīvu efektu. Tas viss kopā veido uzturzinātnes pētījumu lauku [Bacciottini, 2007].

Uztura un onkologisko slimību saistības pētīšana ir komplicēta, jo cilvēks katru dienu uzņem tūkstošiem bioloǵiski aktīvu vielu. Turklāt aktīvo vielu daudzums produktos variē. Agrāki pētījumi uzrāda, ka uztura sastāvdaļas ietekmē daudzus procesus gan veselajās, gan vēža šūnās. Būtiski, ka biologiski aktīvo vielu ietekme uz veselajām un vēža šūnām atšksiras. Bioloǵisko iedarbību ietekmē aktīvo vielu deva, cilvēka dzīves periods, kad notikusi iedarbība, un iedarbības ilgums. Ir pierādījumi, ka uztura faktori ir saistīti ar vēža attīstību, ietekmējot tādus šūnu procesus kā DNS (dezoksiribonukleīnskābes) pārmaiņas, proliferāciju, hormonālo regulāciju, dalīšanos, apoptozi, iekaisuma procesus, kancerogēno metabolismu [Syed, 2007].

Pēdējos gadu desmitos medicīnas zinātniskajā literatūrā palielinās pierādījumu apjoms, ka uzturs nozīmīgi ietekmē onkolog̣isko slimību attīstības risku. Uzskata, ka 30-40\% gadījumu vēžu veidošanās saistīta ar uzturu un citiem dzīvesveida faktoriem. Pasaules Vēža izpētes fonds/ Amerikas Vēža izpētes institūts savā jaunākajā ziṇojumā pauž, ka ar uzturu var novērst trešdaļas onkologisko slimību attīstību [World Cancer Research Fund/ American Institute for Cancer Research, 2007]. Tādējādi populācijas līmen̄̄, veicot vienkāršas pārmaiņas ikdienas uzturā, var būtiski mazināt saslimstību ar vēzi.

Priekšdziedzera vēzis (PV) ir otra biežākā onkologiiskā slimība vīiešiem visā pasaulē un pirmā biežākā l̦aundabīgā onkoloǵiskā slimība Latvijā vīriešiem, kā arī sestais biežākais nāves cēlonis starp visiem vēža veidiem pasaulē un otrais biežākais Latvijā [International Agency for Research on Cancer, 2008; Slimību profilakses un kontroles centrs, 2012]. PV uzskata par ļoti piemērotu prevencijai, jo tas visbiežāk 
attīstās lēni, displastiskas izmaiņas priekšdziedzera audos ir daudzus gadus vai gadu desmitus pirms vēža izveidošanās [Schmid, 2011]. Par apkārtējās vides, tostarp uztura, ietekmi liecina PV incidences un prevalences reǵionālās atšķirības, kā arī migrantu pētījumi: Āzijas vīriešiem ievērojami pieaug PV incidence, mainot dzīvesvietu uz Amerikas Savienotajām Valstīm [World Cancer Research Fund/ American Institute for Cancer Research, 2007]. Āzijas regiiona uztura stūrakmens ir soja un sojas produkti, kas satur fitoestrogēnus - izoflavonus. N̦emot vērā to, ka PV ir hormonāli atkarīgs audzējs, plaši pētīta sojas izoflavonu ietekme, kas kavē PV attīstību [Virk-Baker, 2010]. Savukārt Rietumeiropas valstīs galvenie fitoestrogēnu avoti ir lignāni [Zamora-Ross, 2012]. Ziemel̦eiropas valstīs, kur daudz tiek lietoti pilngraudu produkti, galvenais lignānu avots uzturā ir rudzu maize [Hedelin, 2006; Nurmi, 2010]. Turklāt rudzu maizē ir daudz Šķiedrvielu, kas saistītas ar biolog̣iski aktīvām vielām, tostarp alkilrezorcīniem (AR) un lignāniem, kurām piemīt antioksidatīva aktivitāte. Kopā to dēvē par t.s. aizsargājošo „šķiedrvielu kompleksu”. Alkilrezorcīnus, kas lokalizēti galvenokārt grauda apvalkā, uzskata par pilngraudu produktu marķieriem. Alkilrezorcīnu daudzums maizē liecina par pilngraudu produktu daudzumu tajā, bet alkilrezorcīnu metabolītu daudzums asins plazmā liecina par pilngraudu produktu patēriņu uzturā [Adlercreutz, 2010].

Latvijā pilngraudu produkti ir tradicionāla uztura sastāvdaļa, kaut arī pēdējo gadu laikā arvien vairāk to vietu uzturā aizņem rafinēto (balto, smalko miltu, kas nesatur ne grauda dīgḷa dạ̧iņas, ne klijas) miltu produkti [Pudule, 2011]. Lai izvērtētu rudzu maizes un šķiedrvielu iespējamo aizsargājošo lomu, jāzina alkilrezorcīnu un lignānu daudzums Latvijas rudzu maizē, jāizvērtē rudzu maizes un šķiedrvielu daudzums uzturā, kā arī atsevišķi alkilrezorcīnu un lignānu loma. Bioloǵiski aktīva iedarbība ir gan alkilrezorcīniem un to metabolītiem, kas veidojas aknās, gan arī lignānu metabolītiem, kas veidojas resnajā zarnā zarnu mikrofloras iedarbībā. Lai spriestu par alkilrezorcīnu un lignānu biologiskajiem efektiem, jāizvērtē to metabolisms, analizējot un salīdzinot alkilrezorcīnu un lignānu metabolītu kinētiku biologiskajos šķidrumos (asins plazmā un urīnā), PV pacientiem un kontroles grupai. Rezultāti varētu norādìt, ka PV pacientiem uztura biologiski aktîvo vielu aizsargājošā ietekme ir izmainīta. Šos jautājumus centāmies noskaidrot savā pētījumā.

Cits iespējamais PV riska faktors, kas var ietekmēt PV attīstību, ir D vitamīna līmenis serumā. Pētījumi rāda, ka D vitamīnam ir antikancerogēna aktivitāte, iespējams, D vitamīns ne tikai kavē priekšdziedzera vēža attīstību, bet arī slimības progresēšanu. Iespējams, ka D vitamīna protektīvās darbības pamatā ir iedarbība uz priekšdziedzera 
nukleārajiem D vitamīna receptoriem, kavējot vēža šūnu proliferāciju, šūnu cikla attīstību, vēža šūnu invāziju, angiog์enēzi, veicinot apoptozi, kā arī kavējot iekaisuma prostaglandīnu iedarbību [Karlsson, 2010; Krishnan, 2010]. Pievērsties D vitamīna deficīta izpētei saistībā ar PV rosināja fakts, ka Latvijā saules ekspozīcija ir zema, tāpēc ievērojamai daļai vīriešu iespējama $\mathrm{D}$ vitamīna nepietiekamība, kas varētu ietekmēt kanceroǵenēzi. Mūsu pētījumā noteicām D vitamīna līmeni serumā, kā arī tā daudzumu uzturā PV pacientiem un kontroles grupas dalībniekiem un izvērtējām tā iespējamo protektīvo darbību.

\section{Darba hipotēzes}

1. AR metabolīta DHPPA koncentrācija un kinētika asinīs un AR metabolītu DHPPA (3-(3,5-dihidroksifenil) propānskābes) un DHBA (3,5-dihidroksibenzoskābes) koncentrācija un kinētika 12 stundu dienas un 12 stundu nakts urīnā ir atšķirīga PV un kontroles grupas pacientiem.

2. Lignānu metabolīta enterolaktona (ENL) koncentrācija plazmā, 12 stundu dienas un 12 stundu nakts urīnā ir atšksirīga PV un kontroles grupas pacientiem.

3. Pilngraudu rudzu maize uzturā kavē PV progresēšanu.

4. Vīriešiem pēc 45 gadu vecuma uzturā ir nepietiekams D vitamīna daudzums. D vitamīna līmeni serumā ietekmē D vitamīna daudzums uzturā; D vitamīna nepietiekamība vai deficīts ir izplatîts vīriešiem Latvijā pēc 45 gadu vecuma; D vitamīna deficīts saistīts ar augstāku PV risku.

\section{Pētījuma mērķi}

1. Izpētīt alkilrezorcīnu un lignānu metabolītu saistību ar PV risku un iespējamo ietekmi uz PV progresēšanu.

2. Novērtēt D vitamīna iespējamo protektīvo iedarbību attiecībā uz PV risku. 


\section{Uzdevumi}

1. Izanalizēt Latvijas maizes veidus:

Noteikt lignānu un alkilrezorcīnu daudzumu populārākajos Latvijas un Somijas maizes veidos, salīdzināt ar Ziemeļu un Austrumeiropas reǵiona valstu maizi un papildināt Latvijas produktu uzturvielu datubāzi ar mūsu noteiktajiem lignānu un alkilrezorcīnu daudzumiem dažādos Latvijas maizes veidos.

2. Izanalizēt uzturu PV un kontroles grupā:

- $\quad$ izveidot uztura aptaujas anketu, kura būtu piemērota Latvijas iedzīvotāju ěšanas paradumiem, kurā tiktu iekḷauti Latvijas uzturprodukti, akcentējot pilngraudu produktus un lignānus saturošus produktus;

- $\quad$ noteikt AR un lignānu daudzumu PV un kontroles grupas dalībnieku uzturā un galvenos lignānu uztura avotus.

3. Izpētît AR un lignānu metabolītus biologiskajos šķidrumos PV un kontroles grupā:

- noteikt AR metabolītus (DHPPA plazmā; DHPPA un DHBA 12 stundu dienas un 12 stundu nakts urīnā) un izvērtēt, kurš AR metabolīts ir vispiemērotākais, lai novērtētu rudzu maizes un rudzu šşiedrvielu daudzumu uzturā;

- novērtēt, vai pastāv AR metabolītu (DHPPA plazmā; DHPPA un DHBA 12 stundu dienas un 12 stundu nakts urīnā) diennakts kinētikas atšķirības PV un kontroles grupās;

- noteikt ENL plazmā, 12 stundu dienas un 12 stundu nakts urīnā PV un kontroles grupās un izvērtēt tā saistību ar lignānu daudzumu uzturā.

4. Izpētīt pilngraudu rudzu maizes iespējamo protektīvo iedarbību, kavējot priekšdziedzera vēža progresēšanu, analizējot PSA, dzimumhormonu koncentrāciju un apoptozes aktivitāti priekšdziedzera vēža un riska grupas pacientiem.

5. Noteikt D vitamīna seruma koncentrāciju, daudzumu uzturā un uztura avotus abās pētījuma grupās un novērtēt D vitamīna iespējamo saistību ar PV risku. 


\section{Darba novitāte}

Veikta uzṇemtā uztura novērtēšana PV pacientiem un vīriešiem PV riska vecuma grupā, izmantojot divas metodes: gada uztura biežuma aptaujas anketu un 3 dienu uztura dienasgrāmatu. Līdz šim nav publicēti dati par vecāku cilvēku uzturu Latvijā.

Saistībā ar uzṇemtā uztura datiem analizēta AR un lignānu metabolītu koncentrācija plazmā, 12 stundu dienas un 12 stundu nakts urīnā atsevišksi PV un kontroles grupas dalībniekiem un izvērtēts piemērotākais izmeklējums plazmā un urīnā, kas būtu izmantojams kā biomarķieris pilngraudu maizes un šķiedrvielu daudzumam uzturā. N̦emot vērā mums pieejamo informāciju, līdz šim nav publicēti dati par AR un lignānu metabolītu koncentrāciju 12 stundu dienas urīnā, kā arī nav pētīti AR metabolīti PV pacientiem.

Pētīta pilngraudu rudzu maizes ietekme uz PV progresēšanu.

Izvērtèta D vitamīna koncentrācija plazmā un tās saistība ar D vitamīna daudzumu uzturā PV pacientiem un kontroles grupas dalībniekiem Latvijā. Līdz šim šādi dati nav publicēti. 


\section{LITERATŪRAS APSKATS}

\subsection{Uzturs un vēzis}

Vēzis nav mūsdienu civilizācijas slimība. Vēzis ir aprakstīts jau daudzus gadu tūkstošus p.m.ē. Tā 2698. g. p.m.ē. Nei Ching senākajā Ķīnas medicīnas traktātā iekḷāva pirmos vēža aprakstus reizē ar dažādām ārstniecības metodēm - spirituālo, medikamentozo un arī iekḷaujot diētas rekomendācijas [Ward, 2012]. Līdz zinātniskiem pētījumiem par uztura saistību ar vēzi pagāja ilgs laika periods. Pagājušā gadsimta 30. gados pētījumos ar laboratorijas dzīvniekiem atklāja cēlonisko saistību starp uzturu un dažādu lokalizāciju vēža veidošanos un attīstîbu [Tannenbaum, 1942a; Tannenbaum 1942b]. Pirmie epidemiologiskie pētîjumi, kas norādīja, ka cilvēka uzturam, iespējams, ir nozīme vēža attīstībā, parādījās dažus gadu desmitus vēlāk. Pirmā nozīmīgākā konference „Uztura nozīme vēža attīstībā” notika 1975. gadā Amerikas Savienotajās Valstīs, apkopojot tā laika zināšanas un izpratni par diētas saistību ar vēzi [Wynder, 1975]. Pirmais publicētais konsensus ziņojums, ko veidoja starptautiski atzītu zinātnieku grupa un kas balstīts uz laba dizaina epidemiologiskiem un eksperimentāliem pētījumiem, tika publicēts Amerikas Savienotajās Valstīs 1982. gadā [National Research Council \& Committee on Diet, Nutrition and Cancer, 1982]. Tas bija Nacionālās Zinātņu akadēmijas (National Academy of Sciences (NAS)) atbalstīts Nacionālās Pētniecības padomes ziņojums par diētu un vēzi, kurā tika pausts uzskats, ka vēža incidenci neapšaubāmi ietekmē potenciāli kontrolējami ārēji faktori, tostarp arī uzturs.

Kopš tā laika strauji attīstījās pētniecība šajā jomā: tika izveidota pētniecības bāze eksperimentu veikšanai, notika pētījumi ar dzīvniekiem un epidemiologiskie pētījumi. Zinātnieki pēta gan uztura tradīcijas, gan atsevišķu mikrouzturvielu un makrouzturvielu (pamatuzturvielu) ietekmi uz atsevišksiem vēža veidiem. Epidemioloǵiskajos pētījumos pēta atsevišķu vēža veidu incidences atšķirības dažādos reǵionos. Migrantiem, mainot mītnes zemi ar zemu vēža incidenci (Japānā un citās šī reǵiona valstīs tradicionāli bijusi zema priekšdziedzera, krūts, endometrija vēža incidence) uz zemi ar augstu vēža incidenci (rietumvalstis), strauji pieaug vēža incidence [World Cancer Research Fund/ American Institute for Cancer Research, 2007]. Šie novērojumi norāda uz apkārtējās vides un, īpaši, uz uztura lomu vēža attīstībā. Uzturs spēj ietekmēt kanceroǵenēzi dažādās tās attīstības stadijās. Sākotnējā stadijā šūna ir pakḷauta 
kancerogēnu (tādu faktoru, kas spēj pārveidot šūnas DNS) iedarbībai. Kancerogēni var būt arī specifiski uztura faktori. Nākamajā - veicināšanas - stadijā iespējama spontāna remisija, ko sekmē augšanas inhibitori, tādi kā antioksidanti vai bioloğiski aktīvas vielas augos. N̦emot vērā brīvo radikāḷu lomu kanceroǵenēzē, antioksidantiem ir nozīmīga loma vēža attīstības kavēšanā [Zariņš, 2009]. Antioksidanti tiek saukti par „radikāḷu ķērējiem” (quencher). Pēc Barija Hollivela (Barry Halliwell) un Džona Gateridža (John M.C. Gutteridge) definīcijas, antioksidanti ir ,jebkura substance, kas, klātesot mazā koncentrācijā, ievērojami aizkavē substrātu oksidēšanu vai pasargā no tās”, un zināms, ka endogēnās aktīvās skābekḷa formas piedalās kanceroǵenēzē. [Tirzītis, 2007]. Daudzi augu valsts produkti ir bagātīgi antioksidantu avoti. Dažas uztura sastāvdaļas, kā, piemēram, sojas izoflavoni, iedarbojas līdzīgi hormoniem, tāpēc var kavēt hormonatkarīgu vēžu veidošanos. Citas uztura sastāvdaḷas var kavēt vēža klīnisko manifestāciju. Un, kaut arī iespējams izdalīt atsevišķas aktīvās vielas no uztura produktiem, tomēr nav skaidrs, vai tām tiešam būs tāda pati aizsargājoša ietekme kā pārtikas produktam kopumā, jo tajā daudzas vielas darbojas sinerǵiski [Kiple, 2000].

Saistībā ar vēzi uzturam ir labvēlīga loma daudzos aspektos: vēža prevencija, labāka terapijas tolerance, uzlabots terapijas rezultāts, labāka dz̄ives kvalitāte un lielāka dz̄ivildze. Cilvēka organismu molekulārā līmen̄̄ visvairāk ietekmē gan ar uzturu, gan elpošanas procesā no apkārtējās vides uzṇemtās vielas [World Cancer Research Fund/ American Institute for Cancer Research, 2007], tāpēc neapšaubāma ir uztura potenciālā ietekme uz daudzu slimību attīstības risku, kā arī slimības norises smagumu. Uztura ietekmes pētīšana ir nozīmīga arī tik izplatītam vēža veidam kā priekšdziedzera vēzis.

\subsection{Priekšdziedzera vēzis}

Priekšdziedzera vēža izplatība. Priekšdziedzera vēzis (PV) ir viens no visbūtiskākajiem vīriešu nāves cēloņiem, tā izplatība joprojām pieaug gan pasaulē, gan Latvijā. 2008. gadā pasaulē diagnosticēti 899000 jaunu PV gadījumu, kas ir 13,6\% no visām vīriešu onkolog̣iskajām slimībām [International Agency for Research on Cancer, 2008]. Pēc Slimību profilakses un kontroles centra (SPKC) datiem, Latvijā priekšdziedzera vēzis starp vīriešu onkologiskajām slimībām 2011. gadā ien̦ēmis pirmo vietu incidences ziņā ar 984 jauniem diagnosticētiem gadījumiem [Slimību profilakses un kontroles centrs, 2012] un otro vietu aiz bronhu un plaušu ļaundabīgajiem audzējiem 
mirstības ziṇā (2011. gadā miruši 372 vīrieši) [Slimību profilakses un kontroles centrs, 2012]. SPKC dati norāda, ka 2011. gadā PV veidoja 18,5\% no saslimstības ar visām onkolog̣iskajām slimībām vīriešiem, uzskaitē ar PV atradās 5583 vīrieši, mirstība bija 39,5 uz 100000 vīriešu, rēķinot uz Latvijas standartpopulāciju [Slimību profilakses un kontroles centrs, 2012].

Pēc skrīninga testu atklāšanas deviņdesmito gadu sākumā vairākumā valstu, ieskaitot Latviju, tika novērots straujš PV incidences pieaugums (1.1. attēls) [Kukulis, 2010].

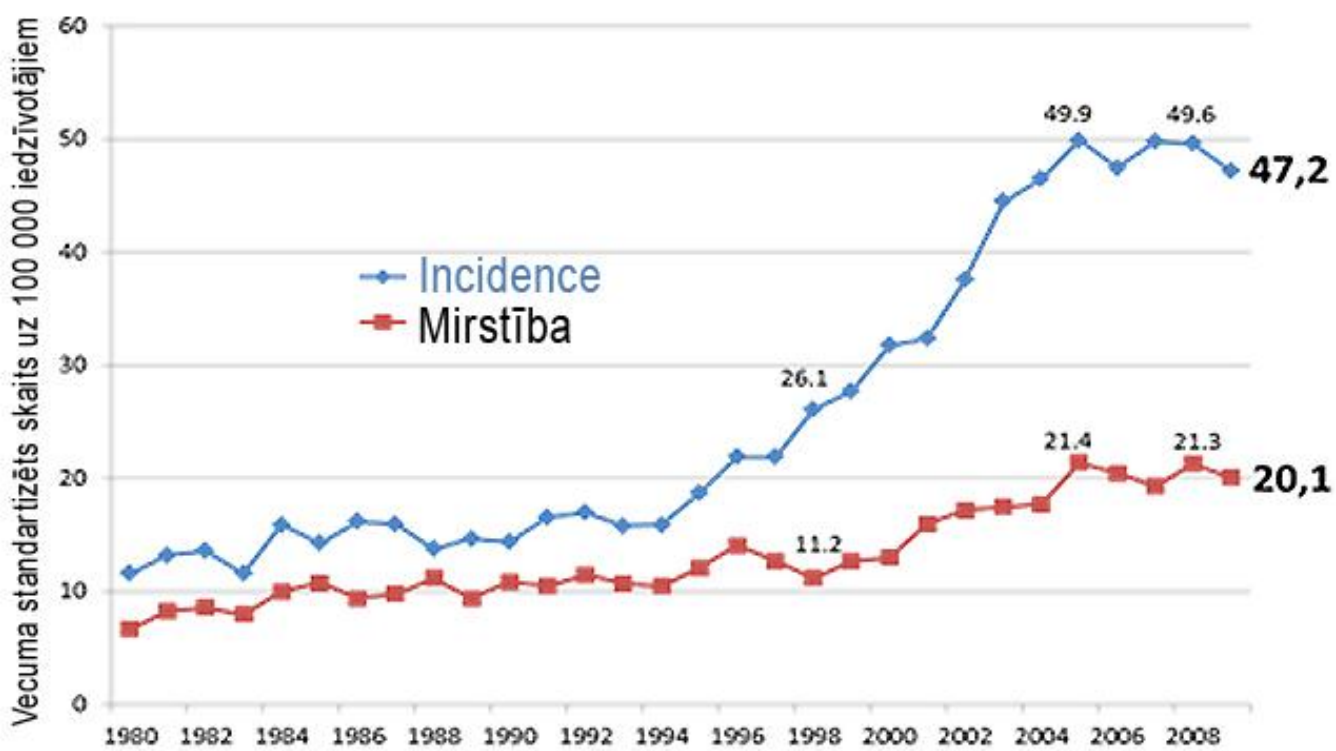

1.1. att. Priekšdziedzera vēža incidence un mirstība Latvijā 1980.-2009.g. [Kukulis, 2010]

Analizējot pasaules populācijas vecuma standartizētos rādītājus, PV mirstība Latvijā saglabājās 20-21 uz 100000 iedzīvotāju, ieņemot trešo vietu Eiropas kontekstā (1.2. attēls) [Bosetti, 2011]. 


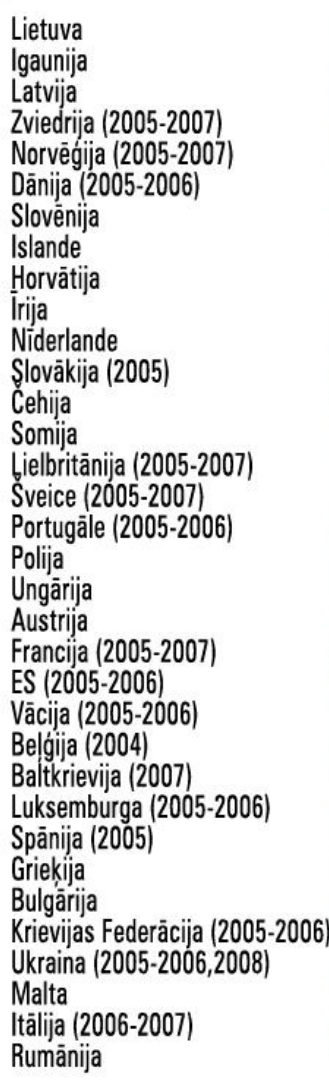

Itälija (2006-2007)

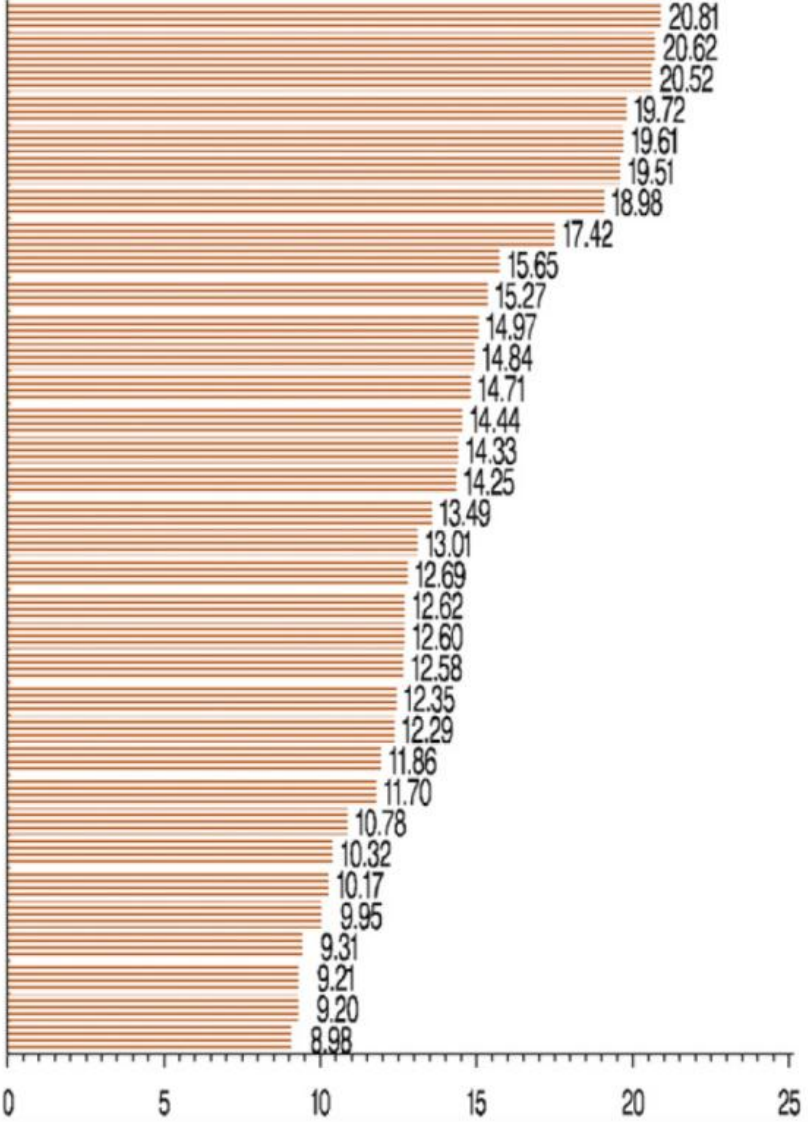

25

\section{2. att. Vecuma standartizēta (pasaules populācija) mirstība no priekšdziedzera vēža 33 Eiropas valstīs 2005.-2008. g. [Bosetti, 2011]}

Priekšdziedzera vēža izplatības reǵionālās atšķirības. Lai gan priekšdziedzera vēža globālā izplatība ir l̦oti augsta, tomēr gan incidencei, gan prevalencei un mirstībai pastāv izteiktas reǵionālas atšķirības. Gandrīz trīs ceturtdaļas PV gadījumu reǵistrē attīstîtajās valstîs. Incidences rādītāji pasaulē variē, atšķkirības sasniedz pat 25 reizes, sasniedzot visaugstākos rādītājus Austrālijāa/Jaunzēlandē, Rietumeiropā, Ziemel̦eiropā un Ziemeḷamerikā. Daḷejji tas skaidrojams ar plašu priekšdziedzera specifiskā antigēna (PSA) un tam sekojošu priekšdziedzera biopsijas lietošanu. Viszemākā vecuma standartizētā incidence ir Dienvidāzijā un Centrālajā Āzijā [International Agency for Research on Cancer, 2008]. Mirstības rādītāji pasaulē atšķiras mazāk, tomēr atšķkirība ir desmitkārtīga. Visaugstākā mirstība ir melnādaino populācijā, vidēja - Eiropā un viszemākā - Āzijā (1.3. attēls) [International Agency for Research on Cancer, 2008]. 


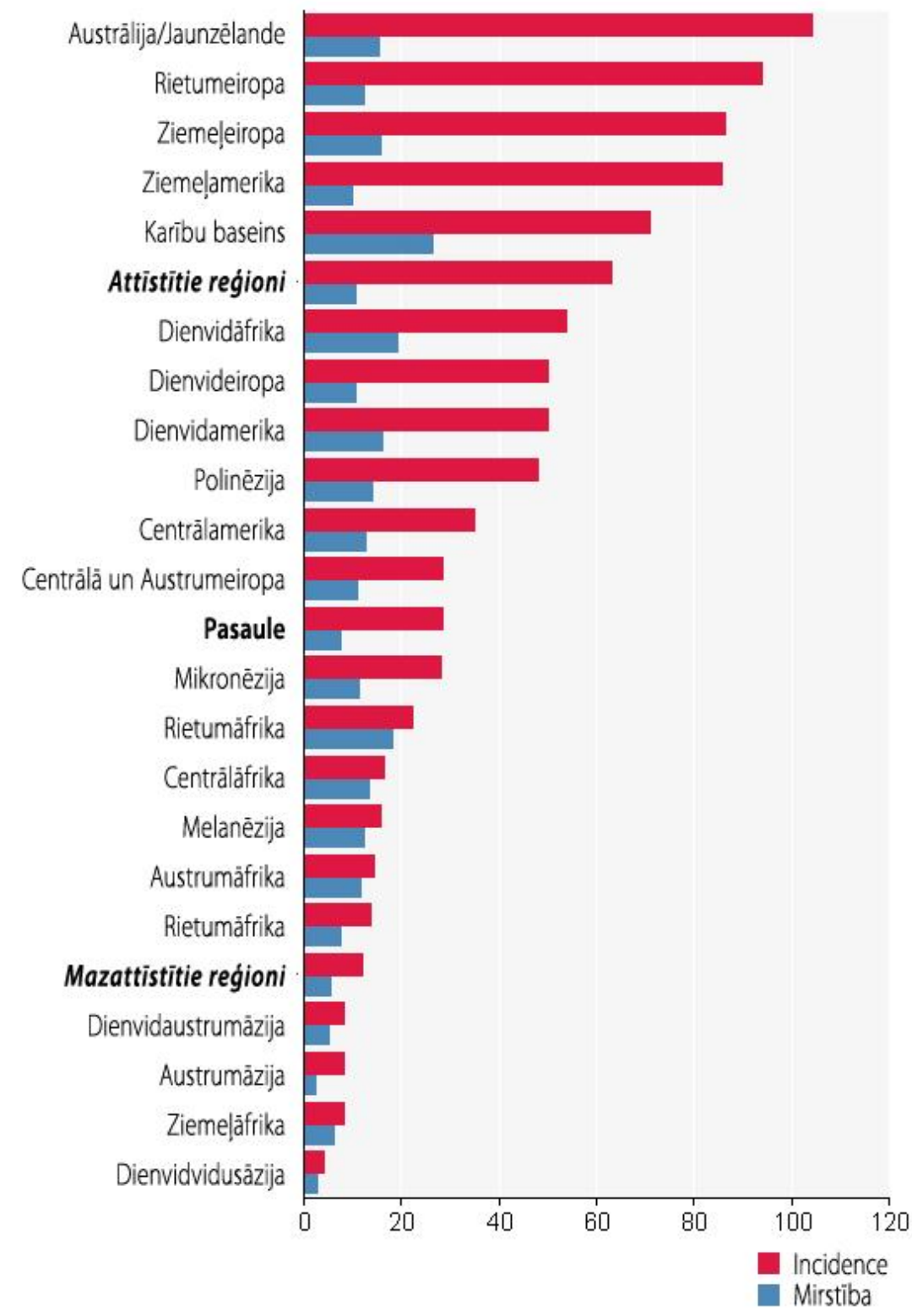

\section{3. att. Vecuma standartizētie rādītāji (pasaule) - incidence un mirstība - uz 100000 iedzīvotāju. GLOBOCAN 2008 Starptautiskā \\ Vēža izpētes aǵentūra, Vēža informācijas nodą̧a \\ [International Agency for Research on Cancer, 2008]}

Izteikti atšksirīgie incidences un mirstības rādītāji dažādos pasaules reǵionos un riska pārmaiṇas migrācijas rezultātā (PV risks pieaug, cilvēkiem migrējot no valstīm ar zemu incidenci uz valstīm ar augstu PV incidenci) norāda, ka PV etiologijā liela loma ir apkārtējās vides un dzīvesveida faktoriem, ieskaitot uztura faktorus [Lichtenstein, 2000; World Cancer Research Fund/ American Institute for Cancer Research, 2007; Lee, 2007; Rastogi, 2008]. Tradicionālā diēta Japānā un Ķīnā ir balstīta vairāk uz augu valsts produktiem, satur daudz graudaugu un pākšaugu. Taukskābes šajā uzturā pārsvarā 
ir nepiesātinātās. „Āzijas diēta” satur daudz biologiski aktīvu vielu, tostarp fitoestrogēnus. Savukārt par t.s. Rietumu diētu tiek uzskatīti uztura paradumi, ko nosaka industrializēts uzturs, kas radās Amerikas Savienotajās Valstīs (ASV), vēlāk to sāka lietot Eiropā, kā arī baltādaino populācija Dienvidāfrikāa, Austrālijā, Jaunzēlandē, un tā joprojām izplatās visā pasaulē. Šiem uztura paradumiem raksturīgs augsts enerǵijas blīvums (attiecība: kcal/ēdiena masa), daudz rūpnieciski pārstrādātu ēdienu, daudz gal̦as un piena produktu, daudz produktu ar augstu tauku un cukura daudzumu, graudaugu produkti no rafinētiem miltiem, kā arī mazāks graudaugu, sakņaugu, citu dārzeņu un augḷu daudzums. Rietumu diētā ir maz fitoestrogēnu un citu bioloǵiski aktīvo savienojumu [World Cancer Research Fund/ American Institute for Cancer Research, 2007].

Priekšdziedzera vēža prevencijas aspekti. Ir konstatēti trīs vispārzināmi PV riska faktori: vecums, etniskā izcelsme un hereditāri faktori [Heidenreich, 2011]. PV incidences un mirstības geogrāfiskās atšķirības, kā arī migrācijas pētījumi norāda uz eksogēno faktoru ietekmi uz PV risku. Eksogēnie faktori ietver dzīvesveidu (fiziskā aktivitāte, smēķēšana), alkohola lietošanu, ultravioletā starojuma ekspozīciju, seksuālo uzvedību, apkārtējās vides ietekmi, kā arī uzturu. Ir dati, ka minētie eksogēnie faktori var ietekmēt t.s. latentā PV progresēšanu par klīniski manifestu PV [Heidenreich, 2011].

PV ir piemērots prevencijai vairāku apsvērumu dēḷ:

1) augsta slimības prevalence [International Agency for Research on Cancer, 2008];

2) PV ir hormonatkarīgs audzējs, to var ietekmēt gan ar farmakologiskām, gan uztura aktīvajām vielām;

3) PV var būt dažāda klīniskā norise - gan agresīva gaita, gan arī nereti tas ir lēni progresējošs audzējs ar ilgstošu latentu periodu. Ir jāpaiet vidēji 10 gadiem, lai no histologiskā prekursora (priekšdziedzera intraepiteliālā neoplāzija) izveidotos invazīvs audzējs, kura klīniskās izpausmes parādās vēl 3-4 gadus vēlāk. Vecākiem vīriešiem, kas miruši dažādu cēloṇu dẹl, autopsijā $60-70 \%$ gadījumu histologiski atrod vēža šūnas priekšdziedzerī, kuras nav progresējušas [Heidenreich, 2011]. PV patoǵenēze sākas 30-40 gadu vecumā un sniedz iespējas preventīviem pasākumiem;

4) PSA ir labs seruma marķieris slimības klīniskai monitorēšanai [Arlen, 2008];

5) pieejams histoloǵiskais prekursors: priekšdziedzera intraepiteliālā neoplāzija [Moore, 2005]. 
Pat mērena slimības kavēšana var būtiski ietekmēt pacientu dzīves kvalitāti. Viens no būtiskākajiem vēža risku ietekmējošiem līdzekḷiem ir hemoprevencija, ko definē kā specifisku vielu lietošanu, lai bloķētu vai kavētu kanceroǵenēzi [Syed, 2007]. Hemoprevencijā izmanto gan medikamentus, gan uztura faktorus, kas var būt gan pārtikas produkti, gan bioloǵiski aktīvi savienojumi uzturā. Uztura faktoriem var būt nozīme gan primārajā, gan sekundārajā PV prevencijā. Primāras prevencijas mērķis ir pasargāt veselus cilvēkus no onkologiisku slimību attīstības, sekundārās prevencijas mērķis - ietekmēt specifiskus riska faktorus augsta riska populācijā (piemēram, mērḳtiecīgas izmaiņas uzturā) [Blackburn, 2010].

Priekšdziedzera vēzis un dzimumhormoni. Estrogēnu loma saistībā ar PV ir pretrunīga. Estrogēniem ir liela nozīme PV attīstībā, un tie tiek arī izmantoti PV terapijā. Vīriešiem estrogēni producējas aromatāzes iedarbībā no androgēniem galvenokārt sēkliniekos, virsnieru garozā un perifērajos audos.

Estrogēni ir iesaistīti enterohepatiskajā cirkulācijāâ, tāpēc uzturs, īpaši tauki un šķiedrvielas, ievērojami ietekmē estrogēnu sadalījumu un koncentrāciju organismā. Enterohepatiskās cirkulācijas mehānisms ir šāds: endogēnajiem estrogēniem nonākot aknās, 50\% tiek izvadīti ar žulti konjugētā formā (pārsvarā konjugēti ar glikuronskābi un nelielos daudzumos ar sulfātiem). Zarnās hidrolīzes rezultātā glikuronskābe un sulfātu grupas tiek atdalītas. Tad brīvie estrogēni absorbējas, bet uzreiz zarnas mukozajās šūnās atkal savienojas ar glikuronskābi un pa vārtu vēnu nonāk aknās. Neliela daļa estrogēnu nonāk vārtu vēnā brīvā formā. Daļa estrogēnu caur aknu vēnu nonāk asinsritē, un daḷa - žultsceḷos. Visa cirkulācija ilgst apmēram sešas stundas [Adlercreutz, 2010].

Estrogēni vīriešiem modulē brīvo androgēnu līmeni plazmā, paaugstinot dzimumhormonu saistošo globulīnu (SHBG), un, iedarbojoties uz hipotalāmu, mazina testosterona sintēzi. Ir identificētas divas galvenās estrogēnu receptoru (ER) izoformas: ER $\alpha$ un ER $\beta$ [Cornwell, 2004]. Lai gan abu veidu receptori var būt lokalizēti vienā šūnā, tomēr ER $\alpha$ vairāk lokalizēti dzemdes, sirds, nieru, aknu audos, bet ER $\beta$ - vairāk olnīcu, plaušu, kuṇgga un zarnu trakta, centrālās nervu sistēmas un hematopoētiskajā sistēmā [Moutsatsou, 2007]. 1.4. attēls atspoguḷo estrogēnu un androgēnu ietekmi uz priekšdziedzera šūnām. Priekšdziedzerī ER $\alpha$ pārsvarā lokalizēti stromas šūnās, bet ER $\beta$ vairāk lokalizēti epitēlijāa Ir norādījumi, ka ER $\alpha$ aktivācija veicina proliferāciju, savukārt ERß aktivācija - apoptozi. Iedarbojoties uz aromatāzi stromā, var veicināt priekšdziedzera šūnu apoptozi [Ho, 2011]. 


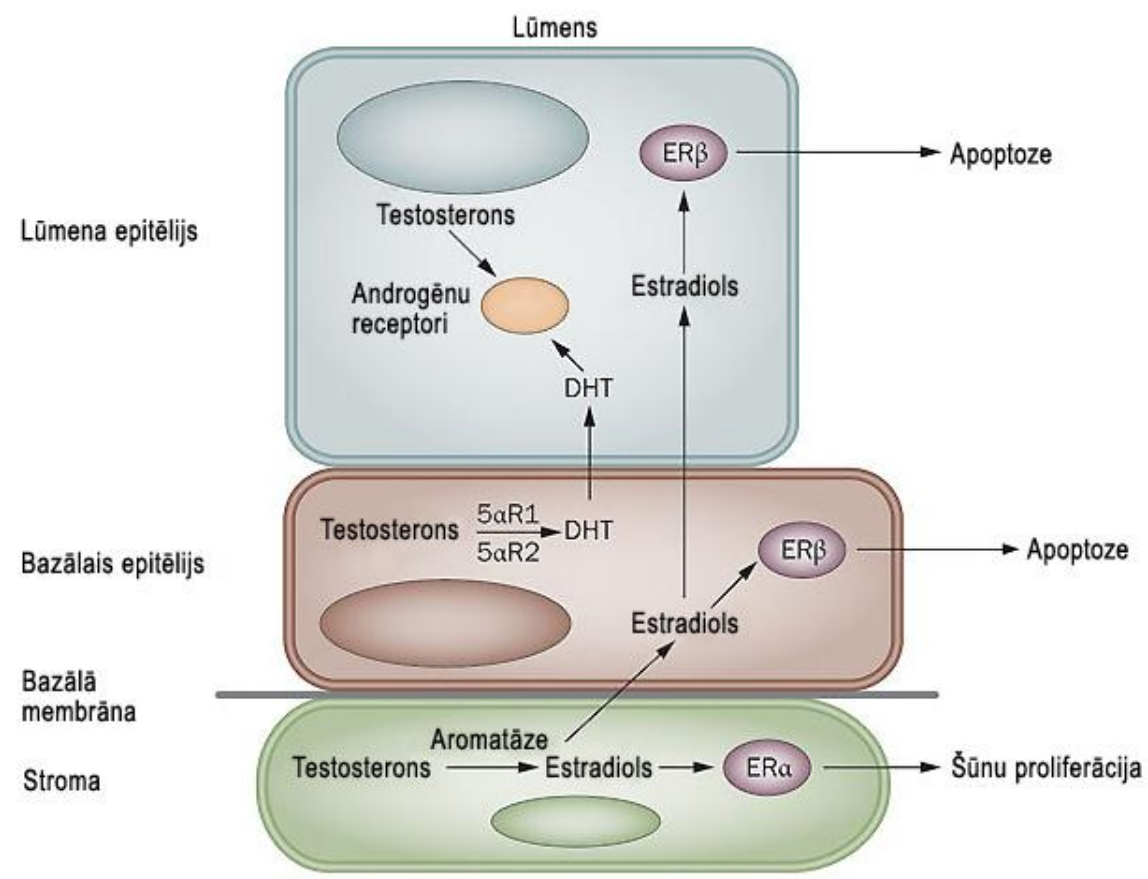

\section{4. att. Estrogēnu un androgēnu iedarbība uz priekšdziedzera vēža} šūnām [Ho, 2011]

$5 \alpha \mathrm{R}-5 \alpha$ reduktāze; DHT - dihidrotestosterons; ER - estrogēnu receptors

Estrogēnus izmanto PV terapijā, tie ar atgriezeniskās saites mehānismu nodrošina kastrāciju, jo kavē hipotalāma-hipofĩzes ass funkcijas un mazina luteinizējošā hormona (LH) atbrīvošanos, kā rezultātā mazinās testikulārā testosterona producēšana un PV palielināšanās. Tajā pašā laikā estrogēni ir saistīti ar labdabīgas priekšdziedzera hiperplāzijas (LPH) un PV attīstību. Tomēr zināms, ka japāņu vīriešiem, kas uzturā lieto daudz sojas produktu, priekšdziedzera masa ir mazāka nekā tāda paša vecuma rietumvalstu vīriešiem. Tāpēc var teikt, ka estrogēniem saistībā ar priekšdziedzera slimībām ir divējāda - gan protektīva, gan slimību veicinoša - loma [Adlercreutz, 2002].

PV saistība ar androgēniem ir kompleksa. Priekšdziedzeris ir no androgēniem atkarīgs orgāns, kurā ir daudz androgēnu receptoru. Ja vīrietis ir kastrēts pirms pubertātes, tad PV neattīstās. Tāpat kā normālu priekšdziedzera šūnu, PV šūnu proliferācija ir atkarīga no androgēniem, tāpēc PV ir atzīts par androgēnu atkarīgu malignitāti [Grossmann, 2012]. Tāpēc PV gan medikamentozās, gan ķirurgisiskās ārstēšanas mērķis ir mazināt androgēnu līmeni. Ar laiku vēža šūnas var kḷūt neatkarīgas no androgēniem un proliferēt bez androgēnu iedarbības. Androgēnu loma kanceroǵenēzē vēl nav izzināta - nav skaidrības, vai tie iniciē PV veidošanos. Androgēnu deprivācijas terapija, ko izmanto PV terapijāa, paaugstina cukura diabēta (CD) risku 
[Grossmann, 2011], bet dzīvildzes prognozes ir labas [Grossmann, 2012]. Abu faktoru metabolo pārmaiņu un cirkulējošo androgēnu pārmaiṇu - mijiedarbība ietekmēe priekšdziedzera biologiju. Nav iegūti dati par PV saistību ar seruma testosterona līmeni [Roddam, 2008].

\subsection{Ar uzturu saistītie priekšdziedzera vēža attīstību ietekmējošie faktori}

\subsubsection{Fitoestrogēni}

Fitoestrogēnu definīcija. Fitoestrogēnus definē kā jebkuru augu valsts substanci vai metabolītu, kas izraisa bioloǵisku atbildes reakciju mugurkaulniekam un var imitēt vai mainīt endogēnā estrogēna darbību, turklāt pastāv strukturāla līdzība ar zīdītāju estrogēnu - 17ß-estradiolu [Knight, 1996]. Cita fitoestrogēnu definīcija par fitoestrogēniem dēvē nesteroīdus polifenolu klases augu metabolītus, kas izraisa biologisku atbildes reakciju un var imitēt vai mainīt endogēno estrogēnu darbību, bieži saistoties ar estrogēnu receptoriem [Committee on Toxicity of Chemicals in Food, Consumer Products and the Environment, 2003].

Fitoestrogēnu struktūra un klasifikācija. Visu fitoestrogēnu molekulās ir bifenola fragments, tāpēc tie ir strukturāli līdzīgi 17ß-estradiolam, kas ir dominējošais estrogēns organismā (1.5. attēls) [de Kleijn, 2001].

Salīdzinājumā ar endogēnajiem estrogēniem fitoestrogēni ar ER saistās zemās koncentrācijās. Fitoestrogēnu ķīmiskā struktūra nosaka to afinitāti, selektivitāti un efektivitāti saistībai ar ER, kas pārsvarā lokalizēti šūnas kodolā. Tāpēc arī dažādiem fitoestrogēniem var novērot dažādus klīniskos efektus. Estradiolam ir vienāda afinitāte uz ER $\alpha$ un ER $\beta$, bet fitoestrogēni vairāk saistās ar ER $\beta$ [Moutsatsou, 2007]. 
<smiles>COc1ccc(-c2coc3cc(O)cc(O)c3c2=O)cc1</smiles>

Biohanīns A<smiles>O=c1c(-c2ccc(O)cc2)coc2cc(O)cc(O)c12</smiles>

Genisteīns<smiles>COc1ccc(-c2coc3cc(O)ccc2c3=O)cc1</smiles>

Formononetīns<smiles></smiles>

Kumestrols<smiles>COc1cc(CC(CO)C(CO)Cc2ccc(O)cc2)ccc1O</smiles>

Sekoizolaricirezinols<smiles>O=c1c(-c2ccc(O)cc2)coc2cc(O)ccc12</smiles>

Daidzeīns

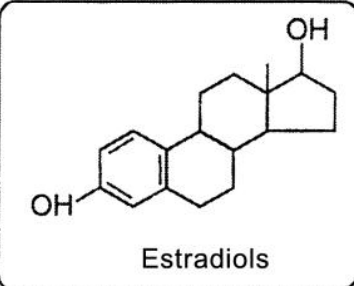<smiles>COc1cc(CC2COC(=O)C2Cc2ccc(O)c(OC)c2)ccc1O</smiles>

Matairezinols

\section{5. att. Fitoestrogēnu un endogēnā estradiola ķīmiskā struktūra}

[de Kleijn, 2001]

Galvenās fitoestrogēnu klases ir izoflavoni, kumestāni un lignāni. Nozīmīgākie izoflavoni ir genisteīns, daidzeīns un to prekursori - formononetīns un biohanīns A. Augos izoflavoni atrodas konjugēti glikozīdu veidā. Cilvēka organismā enzimātisku procesu rezultātā tie tiek hidrolizēti, un zarnu mikrofloras iedarbībā veidojas aktīvie aglikoni. Ekvoli zarnu mikrofloras iedarbībā veidojas no daidzeīna. Nozīmīgākie izoflavonu avoti uzturā ir sojas pupiņas un citi pākšaugi [Cornwell, 2004; Moutsatsou, 2007]. Nozīmīgākais kumestāns ir kumesterols, kura galvenie avoti uzturā ir pākšaugi. Visizteiktākā estrogēnā darbība ir genisteīnam, ekvolam un kumestolam. Lignānu estrogēnā aktivitāte ir mazāka, tomēr Ziemel̦eiropas populācijā tie ir galvenais fitoestrogēnu avots [Boker, 2002; Moutsatsou 2007; Cotterchio, 2008; Carmichael, 2011; Zamora-Ros, 2012], jo daudz tiek lietoti lignānu saturoši produkti, kā, piemēram, pilngraudu produkti. Tāpēc šajā darbā galvenā uzmanība ir pievērsta lignānu ietekmes pētǐšanai. 
Fitoestrogēnu iedarbība. Augu valsts produktu spēju radīt estrogēnu ietekmi pirmoreiz novēroja 1940. gadā, kad aitām, kas ēda daudz sarkanā āboliņa (kas satur daudz fitoestrogēnu), radās fertilitātes problēmas [Bennets, 1946]. Cilvēkiem šāda iedarbība nav novērota. Āzijas valstīs, kur lieto fitoestrogēniem bagātu uzturu, cilvēkiem nav novērota negatīva ietekme uz reproduktīvo sistēmu, un epidemioloǵiskie pētījumi apstiprina fitoestrogēnu lietošanas pozitīvo ietekmi [Moutsatsou, 2007]. Fitoestrogēnu labvēlīgā iedarbība pētîta saistībā ar vēzi, sirds un asinsvadu slimībām, osteoporozi, vīriešu neauglību, aptaukošanos, 2. tipa cukura diabētu (CD) un menopauzes simptomiem. Zināms, ka šo slimība incidence daudz zemāka ir tādās valstīs kā Japāna, kur uzturā lieto daudz fitoestrogēnu [Kuhnle, 2008a].

Tā kā fitoestrogēni darbojas gan kā receptoru agonisti, gan antagonisti, tos arī uzskata par selektīviem estrogēnu receptoru modulatoriem (SERM) [Cornwell, 2004; Virk-Baker, 2010;]. Šīs vielas dažos audos (krūts dziedzeris, dzemde) darbojas kā estrogēnu antagonisti, bet citos (kauli, smadzenes, sirds un asinsvadu šūnas) - kā estrogēnu agonisti. Tāpēc ar tām varētu mazināt postmenopauzes osteoporozes un kardiovaskulāro slimību risku, nepalielinot krūts dziedzeru un dzemdes vēža risku [Moutsatsou, 2007].

Ir pētīta šāda fitoestrogēnu iedarbība un priekšrocības vēža terapijā [Virk-Baker, 2010]:

1) iekaisuma kavēšana;

2) angioǵenēzes kavēšana;

3) metastazēšanās kavēšana;

4) staru terapijas efektivitātes palielināšana;

5) rezistences pret pretvēža medikamentiem mazināšana;

6) nav blakusiedarbības, pat lietojot lielās devās;

7) vēža recidīvu un vēža pacientu mirstības mazināšana.

Fitoestrogēni un priekšdziedzera vēzis. Norādījumi par fitoestrogēnu iespējamo preventīvo ietekmi, mazinot vēža, īpaši hormonatkarīgu vēža veidu, risku, parādījās 20. gs. 80. gadu sākumā Setchell and Adlercreutz publikācijās [Setchell, 1980]. Kopš tā laika turpinās pētījumi par fitoestrogēnu ietekmi uz dzimumhormonu atkarīgu audzēju (īpaši krūts un priekšdziedzera vēža) attīstību. Aprakstīti šādi mehānismi, ar kuru palīizību fitoestrogēni var kavēt PV attīstību [Kuhnle, 2008b; Virk-Baker, 2010; Schmid, 2011]: 
1) antiestrogēnais efekts, darbojoties uz estrogēnu receptoriem;

2) kavē dzimumhormonu receptoru ekspresiju;

3) paaugstina SHBG līmeni, kā rezultātā pazeminās androgēnu (galvenokārt brīvā testosterona) līmenis;

4) negatīvās atpakaļsaistes mehānisms uz gonadotropīnu un nozīmīgu steroīdu biosintēzes enzīmu kavēšana (17ß-hidrosterō̄du dehidrogenāze, $5 \alpha$ reduktāze);

5) testosterona intraprostatiskā metabolisma kavēšana, ko nodrošina $5 \alpha$ reduktāzes kavēšana;

6) kavē PV augšanu, iedarbojoties uz augšanas faktoriem;

7) nomācot tirozīnkināzi un topoizomerāzi, samazina DNS sintēzi;

8) antioksidatīva darbība, kā rezultātā samazinās brīvo radikāḷu ietekme;

9) veicina PV šūnu apoptozi;

10) kavē neoangioǵenēzi un metastazēšanos;

11) citohroma $\mathrm{P} 450$ aktivācijas kavēšana;

12) ietekmē gēnus, kas iesaistīti audzēja progresēšanas procesā.

Sojas produkti. Sojas produkti satur daudz biologiski aktīvu vielu, bet par visefektīvāko tiek atzīti fitoestrogēni - izoflavoni (daidzeīns un genisteīns). Āzijas valstīs daudz tiek lietoti sojas produkti un PV incidence ir mazāka. Metaanalīze rāda, ka sojas produktu lietošana ir negatīvi saistīta ar PV risku Āzijas valstīs, bet saistības nav rietumvalstīs [Jian, 2009]. Skaidrojums varētu būt saistīts ar to, ka rietumvalstīs patērētās sojas daudzums ir par mazu, lai sasniegtu protektīvu iedarbību. Turklāt sojas produkti ir daḷa no Austrumu tradicionālās diētas, un, iespējams, ietekme ir arī atšķirīgām zarnu baktērijām un to aktivitātei, metabolizējot izoflavonus. Savukārt rietumvalstīs uzturs, kas satur daudz gaḷas un maz dārzeņu, nodrošina atšķirīgu zarnu mikrofloru un līdz ar to arī neefektīvāku izoflavonu metabolizāciju un tāpēc arī bioloǵisko ietekmi [Cheetham, 2011]. Sojas lietošana saistīta arī ar mazāku mirstību no PV [Schmid, 2011].

\subsubsection{Lignāni}

Lignānu struktūra. Lignāni ir biologiski aktīvi augu valsts fenoli, kam nav enerḡètiskās vērtības [Peterson, 2010]. Lignāni augu valsts produktos atrodas pārsvarā glikozīdu veidā (1.5. attēls). Lignānu loma augu valstī ir piedalīšanās augu aizsardzības 
procesos (darbojoties kā antioksidantiem, biocīdiem), nodrošinot aizsardzību pret slimībām un kaitēkḷiem un, iespējams, piedaloties augu augšanas procesu kontrolē [Saleem, 2005].

Tiek uzskatīts, ka augu valsts lignāniem nepiemīt hormonāla aktivitāte, toties tāda piemīt to metabolītiem, t.s. enterolignāniem - enterolaktonam (ENL) un enterodiolam (END), kuru struktūra ir līdzīga estrogēnu struktūrai. Pastāv ievērojamas atšķirīibas starp indivīdiem lignānu metabolismā (enterolignānu veidošanās procesā) un biopieejamībā.

Lignāni uztura produktos. Lignāni sastopami pārsvarā augu valsts produktos. Tie noteikti ļoti plašā produktu klāstā, ko lieto rietumvalstīs. Analizējot augu valsts produktus, lignānus var noteikt 95-100\% augu valsts produktu [Milder, 2005; Thompson, 2006]. Pētot biežāk lietotos ēdienus un produktus Lielbritānijā un Kanādā, atzīts, ka lignāni bijuši visnozīmīgākie fitoestrogēni lielākajā daḷā produktu (izņemot pārtikas produktus, kas satur soju) [Thompson, 2006; Kuhnle, 2008a]. Sākotnēji pieņēma, ka vienīgie enterolignānu prekursori ir sekoizolaricirezinols (SECO) un matairezinols (MAT). Produktos tika noteikti tikai SECO un MAT, un šie dati iekḷauti fitoestrogēnu datubāzēs [Horn-Ross, 2000a; Boker, 2002; Valsta, 2003]. Vēlākos gados, kad kḷuva zināmi citi enterolignānu prekursori, tika veidotas jaunas lignānu datubāzes, iekḷaujot arī laricirezinolu (LAR) un pinorezinolu (PIN) [Milder, 2005; Thompson, 2006] un turpmāk pat sešus lignānus, ieskaitot siringarezinolu (SYR) un mediorezinolu (MED) [Moreno-Franco, 2011]. Lignānu daudzums augu valsts produktos variē no $0 \quad$ līdz $300000 \mu \mathrm{g} / 100 \quad \mathrm{~g}$. N̦emot vērā četru lignānu vērtību summu, kopējā lignānu koncentrācija lielākajā daḷā produktu pārsvarā nepārsniedz $2000 \mu \mathrm{g} / 100 \mathrm{~g}$ [Peterson, 2010]. Izņēmums ir linsēklas (301 $129 \mu \mathrm{g} / 100 \mathrm{~g})$ un arī sezama sēklas (29 $331 \mu \mathrm{g} / 100 \mathrm{~g}$ ), kas satur lignānus ievērojami augstākā koncentrācijā nekā citi augi [Milder, 2005]. Lignāni vērā n̦emamos daudzumos ir arī citās sēklās (lignāni pārsvarā lokalizēti sēklu apvalkos). Lignānu koncentrācija graudaugos ir no 7 līdz 764 mg/100 g. Nozīmīgākie lignānu avoti ir pilngraudu produkti, jo lignāni pārsvarā lokalizēti grauda apvalka - klijas daļā. Daudz lignānu ir rudzos, miežos, griķos, auzu pārslās, kviešos, pākšaugos, riekstos. Mazākos daudzumos lignāni sastopami augḷos, ogās un dārzeņos, piemēram, vīnogās, kivi, citronos, apelsīnos, zemenēs. Īpaši daudz lignānu (185$232 \mu \mathrm{g} / 100 \mathrm{~g}$ ) satur krustziežu dzimtas dārzeņi (galviņkāposti, ziedkāposti, rāceņi, kāḷi, redīsi). Lignānus satur arī dzērieni: sarkanvīns (91 $\mu \mathrm{g} / 100 \mathrm{~g})$, tēja, kafija [Milder, 2005; Thompson, 2006]. 1.1. tabulā parādīts lignānu daudzums dažādos produktos. 
Lignānu daudzums produktos $(\mu \mathrm{g} / 100 \mathrm{~g}$, dzērienos $-\mu \mathrm{g} / 100 \mathrm{ml})$ Nīderlandes lignānu datu bāzē [Milder, 2005]

\begin{tabular}{l|c|c|c|c|c|c}
\hline \multicolumn{1}{c|}{ Uztura produkts } & LAR & PIN & SECO & MAT & Kopa \\
\hline Sēklas un rieksti & 3041 & 3324 & 184219 & 553 & 301129 \\
\hline Linsēklas & 9470 & 29331 & 66 & 481 & 39348 \\
Sezama sēklas & 496 & 0 & 133 & 0 & 629 \\
Indijas rieksti & 10 & 0 & 0 & 0 & 10 \\
Zemesrieksti & 220 & 383 & 11845 & 26 & 12474 \\
\hline Graudaugi & 122 & 172 & 13 & 14 & 320 \\
\hline Pilngraudu maize ar linsēklām & 38 & 28 & 17 & 0 & 83 \\
Rudzu maize & 7 & 0 & 0 & 0 & 7 \\
Kviešu maize &
\end{tabular}

Sakṇaugi, citi dārzeņi un pākšaugi

\begin{tabular}{l|c|c|c|c|c} 
Lapu kāposti & 559 & 1691 & 19 & 12 & 2321 \\
Ziedkāposti & 124 & 58 & 4 & 0 & 185 \\
Ķiploki & 286 & 200 & 50 & 0 & 536 \\
Sīpoli & 19 & 0 & 18 & 0 & 36 \\
Burkāni & 60 & 19 & 93 & 0 & 171 \\
Gurḳi & 59 & 1 & 8 & 0 & 67 \\
Konservētas brūnās pupas & 13 & 3 & 10 & 0 & 26 \\
\hline
\end{tabular}

Augli

\begin{tabular}{l|c|c|c|c|c} 
Zemenes & 117 & 212 & 5 & 0 & 334 \\
Plūmes & 4 & 74 & 4 & 0 & 82 \\
Āboli & 1 & 0 & 0 & 0 & 1 \\
Gaišăs rozīnes & 153 & 0 & 9 & 19 & 181 \\
\hline
\end{tabular}

Tauki

\begin{tabular}{l|c|c|c|c|c} 
Olīvelı̣a, nerafinēta, auksti spiesta & 4 & 243 & 0 & 0 & 248 \\
Rafinēta olīveḷıa & 5 & 101 & 0 & 0 & 106 \\
Saulespuķu elı̣ı & 0 & 0 & 0 & 0 & 0 \\
Margarīns & 7 & 0 & 32 & 0 & 39 \\
\hline
\end{tabular}

Citi produkti

\begin{tabular}{l|c|c|c|c|c}
\hline Tomātu pasta & 107 & 70 & 9 & 0 & 187 \\
Šokolāde & 20 & 23 & 0 & 0 & 44 \\
\hline Dzērieni & 15,9 & 6,3 & 61,3 & 7,8 & 91,3 \\
\hline Sarkanvīns & 11,9 & 3 & 7,6 & 3 & 25,5 \\
Baltvīns (Francijas) & 9 & 21,7 & 1 & 0 & 31,6 \\
Alus (Heineken) & 30,4 & 40,6 & 5 & 1,1 & 77,1 \\
Melnā tēja, Ceilonas & 9 & 0,4 & 9,4 & 0 & 18,7 \\
Kafija & 7 & 7,5 & 2,7 & 0 & 17,2 \\
Apelsīnu sula & 0 & 0 & 0 & 0 & 0 \\
\hline Kola &
\end{tabular}

SECO - sekoiziolaricirezinols, MAT - matairezinols, LAR - laricirezinols, PIN - pinorezinols, MED - mediorezinols, SYR - siringarezinols 
Atsevišķu lignānu saturs atšķiras arī dažādos produktos. Dominējošais lignāns linsēklās un graudaugos ir SECO, sakņaugos, citos dārzeņos un auglos - LAR un PIN [Milder, 2005].

Lignānu daudzums produktos variē atkarībā no daudziem faktoriem: augu šķirnes, augšanas apstākļiem, novākšanas sezonas, ǵeogrāfiskajiem faktoriem, pārstrādes veida. Lignānu daudzuma variācijas koeficients ir 33\% [Kuhnle, 2008a].

Atšķirībā no augu valsts produktiem lignānu gandrīz nav dzīvnieku valsts produktos. L,oti nelielos daudzumos dzīvnieku valsts produktos (pārsvarā piena produktos) ir enterolignāni (ENL un END), kas rodas dzīvnieku zarna traktā baktēriju iedarbībā (vidēji $6 \mu \mathrm{g} / 100 \mathrm{~g}$ ), kā arī neizmainīti lignāni (arī vidēji $6 \mu \mathrm{g} / 100$ g). Ir noteikts lignānu un enterolignānu daudzums piena produktos, olās, gaḷā un zivīs [Kuhnle, 2008a].

Par produktu pārstrādes ietekmi uz lignānu daudzumu nav daudz datu. Zināms, ka, vārot produktus, ievērojami mazinās lignānu daudzums, jo lignāni no produkta nonāk ūdenī, kurā tiek gatavots ēdiens [Thompson, 2006]. Savukārt termiskā apstrāde bez ūdens (cepšana, mikroviḷnu krāsns) lignānu daudzumu mazina tikai nedaudz, šīs vielas gatavošanas laikā saglabājas stabilas[Milder, 2005]. Izžāvējot produktus, lignānu daudzums palielinās, jo mazinās ūdens daudzums produktā. Mizošana mazina lignānu daudzumu sakņaugos, citos dārzeņos un augḷos [Kuhnle, 2008a]. Sēklu pārstrāde būtiski nemaina lignānu daudzumu [Strandas, 2008]. Lignānus produktos nosaka ar gāzu hromatogrāfijas-masspektroskopijas metodi [Penalvo, 2005a; Milder, 2004].

Lignānu daudzums un avoti uzturā. Lignānu daudzumu uzturā dažādu valstu iedzīvotājiem ir sarežğìti izvērtēt, jo dažādos pētîjumos izmantots atšķirīgs lignānu veidu skaits, un lignānu datu bāzes tika pilnveidotas pakāpeniski. Sākotnēji pētījumos, novērtējot uzṇemto lignānu daudzumu, ņēma vērā tikai divus lignānus - SECO un MAT, jo tie bija vienīgie identificētie lignāni un nebija zināms par citu lignānu esamību [de Kleijn, 2001; Boker, 2002; Kilkkinen, 2003a; Valsta, 2003]. Arī daudzos jaunākajos pētījumos tiek izmantoti tikai SECO un MAT, jo izveidota ļoti plaša šo lignānu datubāze, kas ietver 500 produktu un ēdienu [Kuhnle, 2008a; Carmichael, 2011]. Šo pētījumu rezultāti rādīja, ka uzṇemto lignānu daudzums ir 150-578 $\mu \mathrm{g} / \mathrm{d}$ (mediāna). Ja uzņemto lignānu daudzums tiek novērtēts, ņemot vērā četrus lignānus (SECO, MAT, PIN, LAR), tad tas ir no 857 līdz $1258 \mu \mathrm{g} / \mathrm{d}$ [Milder, 2005]. Savukārt, ieskaitot sešus lignānus (SECO, MAT, PIN, LAR, SYR, MED) [Milder, 2005; Touillaud, 2007; 
Cotterchio, 2008; Nurmi, 2010; Zamora-Ros, 2012], uzņemto lignānu mediāna ir no 1632 līdz 3045 g/d [Hedelin, 2006; 2008].

Dažādās valstīs lignānu uztura avoti ievērojami atšķkiras:

- Zviedrijā vīriešiem - rudzu maize (39\%) un linsēklas (36\%) [Hedelin, 2006];

- Somijā vīriešiem - rudzu miltu produkti, ogas, kafija, sakņaugi (47\%) [Nurmi, 2010];

- Nīderlandē - dzērieni (37\%), no tiem tēja un kafija (30\%), dārzeņi (24\%) [Milder, 2005];

- $\quad$ Francijā sievietēm - aug̣̦i un dārzeņi (66\%) [Touillaud, 2007];

- Amerikas Savienotajās Valstīs sievietēm pirms dzemdībām - augli un dārzeņi (69\%) [Carmichael, 2011]; postmenopauzē - apelsīnu sula un kafija (40\%) [Horn-Ross, 2000a; b];

- Kanādā sievietēm - linsēklas (88\%) [Cotterchio , 2008];

- Vidusjūras valstīs - aug̣̣i (31\%), dārzeņi (26\%) un vīns (8\%) [Zamora-Ros, 2012];

- Eiropas valstīs, kas neietilpst Vidusjūras reǵionā, - dārzeṇi (23\%) un graudaugi (20\%) [Zamora-Ros, 2012].

\section{Lignānu metabolisms}

Lignānu metabolisms gremošanas trakta augšējā daḷā. Augu lignānus cilvēks uzņem ar uzturu. Tādiem procesiem gremošanas trakta augšējā daļā kā èdiena košļāšanai, siekalu iedarbībai, ķīmiskai hidrolīzei kuņĝ̣̄, mukozo šūnu fermentatīvajai aktivitātei, iespējams, ir ietekme uz lignānu biopieejamību, bet šo procesu būtiskuma pakāpe nav līdz galam noskaidrota [Clavel, 2006a; b]. Baktērijām mutes dobumā nevar būt liela nozīme, jo uzturs tur atrodas īslaicīgi, kunģa vide nav piemērota baktēriju kolonizācijai. Lignānu glikozīdi no tievajām zarnām neuzsūcas vai uzsūcas slikti, jo tiem ir hidrofoba struktūra, un, tā kā tie ir $\beta$ glikozīdi, tos slikti hidrolizē cilvēka enzīmi, bet efektīvi - baktēriju enzīmi. Tomēr nelielos daudzumos lignāni uzsūcas no zarnu trakta neizmainītā veidā, un tos var noteikt urīnā. Cēlonis, iespējams, ir nepietiekama zarnu baktēriju kapacitāte vai pārāk liels lignānu daudzums uzturā [Clavel, 2006a]. 
Metabolisma procesi zarnu baktēriju iedarbībā. Lignāni tiek metabolizēti resnās zarnas proksimālajā daḷā par END un ENL zarnu mikrofloras iedarbībā. Ilgu laiku bija zināmi tikai divi enterolignānu prekursori: SECO un MAT. Tagad ir identificēti daudzi citi lignāni: PIN, LAR, mediorezinols (MED), siringarezinols (SYR), 7-hidroksimatairezinols (HMR), sezamīns. Zarnu baktērijas producē katalītiskos enzīmus, un tām ir izšķiroša loma lignānu metabolismā. Zarnās notiek enzimātiska augu lignānu pārvēršanās par ENL un END. Lai no uztura lignāniem veidotos enterolignāni, zarnu baktērijas katalizē secīgas reakcijas: glikolīzi (glikozidāzes atdala glikozes daḷu un atbrīvo biologisiski aktīvus aglikonus), demetilěšanu, dehidrogenēšanu, dehidroksilēšanu [Clavel, 2006a]. Pinorezinols (PIN) tiek pārvērsts par laricirezinolu (LAR), kas tālāk tiek metabolizēts par sekoizolaricirezinolu (SECO) un matairezinolu (MAT), kas attiecīgi tiek pārvērsts par ENL un END. END tiek oksidēts par ENL. (1.6. attēls) [Clavel, 2006b].

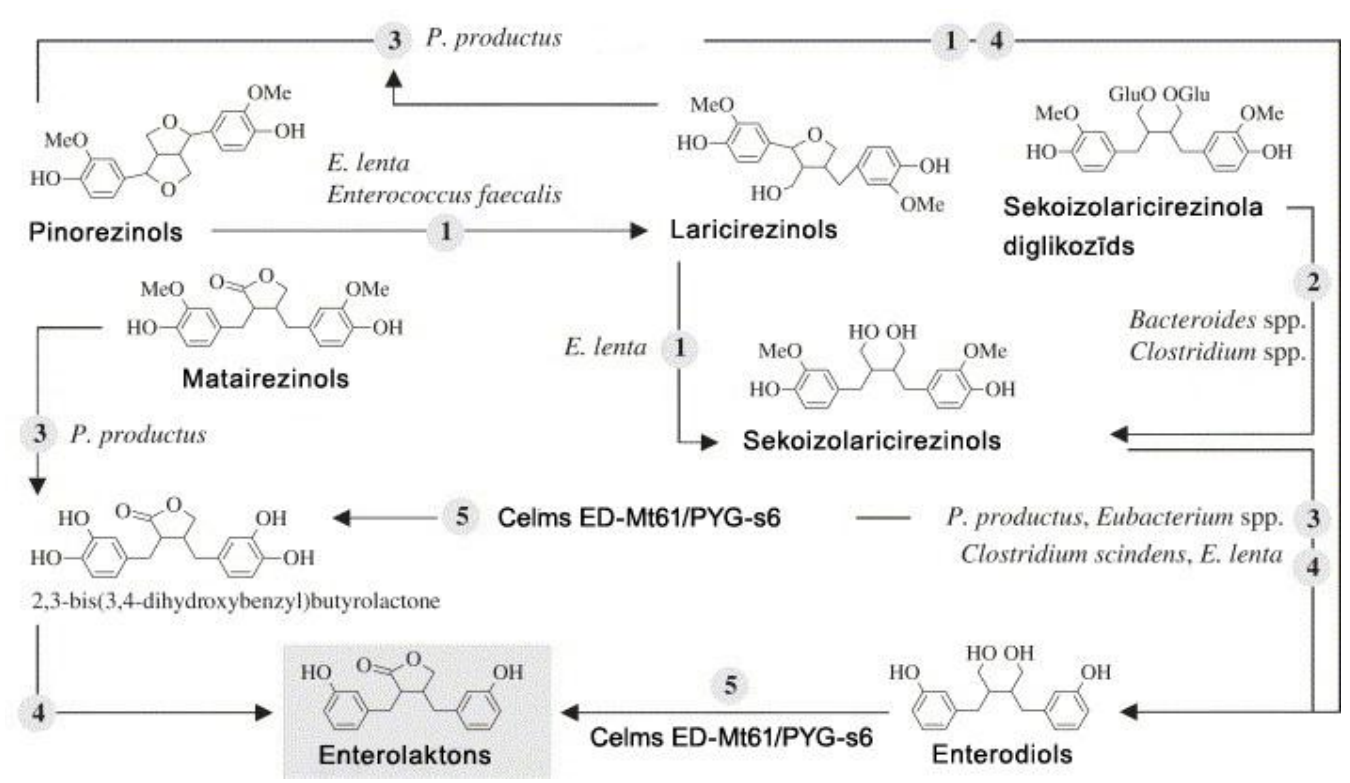

1.6. att. Enterolaktona veidošanās no dažādiem augu lignāniem.

Cilvēka zarnu baktēriju katalizētās reakcijas: 1 - reducēšana; 2 - glikolīze;

3 - demetilēšana; 4 - dehidroksilēšana; 5 - dehidrogenēšana. [Clavel, 2006b]

Lai zarnā sekmīgi noritētu lignānu pārveidošanās, nepieciešama funkcionāli atbilstoša anaerobā mikroflora katrā metabolisma ķēdes posmā (1.6. att.). Dominējošā loma ir Lactobacilli, Bacteroides un bifidobaktērijām. Lignānu metabolismam nepieciešamās baktērijas ir normālas zarnu mikrofloras sastāvā. Jādomā, ka individuālās atšķirīibas enterolignānu veidošanās procesā nosaka arī lignānus pārveidojošo baktēriju daudzums zarnu saturā [Clavel, 2006a]. 
Visi lignāni nekad nepārveidojas 100\%. MAT metabolizējas tieši par ENL. In vitro fekālās mikrofloras metabolisma sistēmā konstatētas dažādas lignānu pārveidošanās pakāpes 24 stundu laikā. LAR pārveidojas pilnībā, citi lignāni tikai daļēji: MAT 62\%; SECO 72\%; PIN 55\%; SYR 4\% [Heinonen, 2001].

Enterolignānu uzsūkšanās un koncentrācija asin̄̄s. Kad zarnu baktēriju iedarbībā izveidojušies enterolignāni (ENL un END), tie pārvar zarnu barjeru. Enterocītos enterolignāni tiek absorbēti, konjugēti ar glikuronīdiem un tad izvadīti laukā (in vitro pētījumi ar cilvēka zarnu šūnu kultūrām) [Jansen, 2005]. Neliela daļa lignānu tiek ātri absorbēti un nonāk asinsritē vienas stundas laikā [Penalvo, 2005b]. Konjugēěana un ekskrēcija asin̄̄s notiek 8-10 stundu laikā [Kuijsten, 2005a], ENL tiek metabolizēts un izvadīts ātrāk nekā END [Clavel, 2006a], ENL koncentrācija ir 5-10 reižu augstāka par END koncentrāciju.

Plazmā var noteikt gan neizmainītus lignānus, gan to metabolītus. Vidējā enterolignānu koncentrācija (ENL plus END) asin̄̄s cilvēkam ar ierasto ikdienas uzturu ir no 10 līdz 270 nmol/L [Lampe, 2003; Stattin, 2004; Hedelin, 2006]. Sievietēm enterolignānu koncentrācija plazmā ir augstāka, un tos var noteikt ātrāk (ātrāks metabolisms) [Kuijsten, 2005a].

Enterolignānu koncentrāciju plazmā nosaka daudzi faktori [Kilkkinen, 2001; Kuijsten, 2005b; Adlercreutz, 2007; 2010]:

1) lignānu daudzums un veids uzturā;

2) lignānu pārveidošanās \% par enterolignāniem;

3) produkta veids uzturā (piemēram, maltām linsēklām ir augstāka biopieejamība nekā veselām sēklām);

4) zarnu mikroflora, ko ietekmē:

- individuālas atšķirības enterolignānus producējošo baktēriju daudzumā;

- antibiotiku lietošana, kas iznīcina baktērijas, kuras ir atbildīgas par enterolignānu veidošanos zarnās. Normālas zarnu mikrofloras atjaunošana ilgst līdz pat 1 gadam;

5) zarnu slimības, zarnu rezekcija, zarnu motilitāte, kuņǵa $\mathrm{pH}$, mucīna, žults sekrēcija, zarnu tranzīta laiks.

6) tauki uzturā mazina un šķiedrvielas palielina ENL veidošanos ar nosacījumu, ja ir normāla zarnu mikroflora.

7) smēķēšana un aptaukošanās mazina ENL līmeni plazmā. 
Lignānu enterohepatiskā cirkulācija un uzkrāšanās audos. Enterolignāni, tāpat kā endogēnie estrogēni, arī iesaistās enterohepatiskajā cirkulācijā vai tiek izvadīti ar urīnu. Pirms nonākšanas cirkulācijā enterolignāni un lignāni (aglikoni) tiek konjugēti ar glikuronskābi un mazākā mērā ar sērskābi zarnu mukozajās šūnās vai aknās [Kuijsten, 2005a]. Tālāk tie iesaistās enterohepatiskajā recirkulācijā vai tiek eliminēti ar žulti vai urīnu [Jan, 2009].

Lignānu metabolīti uzkrājas audos. Augstā koncentrācijā - aknu audos, zarnās (pārsvarā caecum), nierēs un dzemdē. Lignāni ir noteikti arī ejakulātā, priekšdziedzera audos, krūts dziedzera audos, aspirātā no krūts dziedzera, mātes pienā, nabassaites plazmā, aug̣̦a ūden̄̄ [Lampe, 2003]. Priekšdziedzera audos enterolignānu koncentrācija bija 2-3 reizes augstāka nekā plazmā. Ir pētījumi, kas norāda, ka lignānu uzkrāšanās audos var veicināt lignānu protektīvo ietekmi - iedarbību uz audzēja nekrozes faktora $\alpha$ (TNF $\alpha$ ) producēšanu, sterō̄dus metabolizējošo enzīmu kavēšanu [Adlercreutz, 2007].

Lignānu ekskrēcija. Lignāni pārsvarā tiek izdalīti ar urīnu, bet nelielā daudzumā arī ar fēcēm. ENL eliminācijas pusperiods ir 12,6 stundas. Urīnā var noteikt gan neizmain̄itu lignānus, gan to metabolītus. Tāpat kā plazmā, urīnā ENL koncentrācija ir augstāka (100-5000 nmol/d) nekā END koncentrācija (10-1000 nmol/d). ENL koncentrācija urīnā korelē ar ENL koncentrāciju plazmā. Urīnā konstatē 40\% no ar uzturu izņemtā lignānu daudzuma. Divu dienu laikā no organisma tiek izvadīti gandrīz visi lignāni [Kuijsten, 2005a]. Ar fēcēm tiek izvadīti gan neizmainīti augu lignāni, gan enterolignāni (100-1500 nmol/d) [Clavel, 2006a].

\section{Enterolaktons - biomarķieris lignānu daudzumam uzturā}

ENL - plazmā, urīnā nosaka ar gāzu hromatogrāfiju-masspektroskopiju un ar augstas izšķirtspējas šķidruma hromatogrāfiju [Adlercreutz, 2007]. Novērtējot uzņemto lignānu, tāpat kā citu uzturvielu daudzumu uzturā, rodas neizbēgami ierobežojumi. Uzņemtais uzturs (gan kvantitatīvi, gan kvalitatīvi) tiek novērtēts, izmantojot dažādas metodes -uztura biežuma aptauju, uztura dienasgrāmatu, 24 stundu atcerēšanās aptauju. Vienmēr rodas zināma kḷūda, jo respondenti bieži nesniedz objektīvu informāciju, arī porciju izmēri bieži tiek novērtēti neatbilstoši [Lampe, 2003]. Tiek izmantotas dažādas uztura produktu datubāzes, kurās ir atšksirīgas uzturvielu, tostarp arī lignānu, koncentrācijas. Lignānu daudzums uzturproduktos variē (dažādi auga ǵenētiskie, 
ǵeogrāfiskie u.c. faktori). Lignānu daudzums noteikts tikai daļai no produktiem, datu bāzes mainās, tiek pilnveidotas. Dažādos pētījumos izmanto dažādas datubāzes. Patērētāji lieto daudzus funkcionālus produktus un uztura bagātinātājus, kas arī var saturēt lignānus. Veicot uzņemtā uztura novērtēšanu, ne vienmēr iespējams fiksēt šos produktus vai arī nav zināmas lignānu vērtības šajos produktos un tos nevar ietvert kalkulācijā.

Nosakot lignānus un to metabolītus biologiskajos şķidrumos, iespējams precīzāk novērtēt lignānu ekspozīciju cilvēka organismā. Biomarķieru lietošanai ir ievērojamas priekšrocības:

1) biomarķieri ir objektīvi mērījumi, tie nav atkarīgi no uztura datu iegūšanas metodēm un to nepilnībām uzturproduktu datubāzēs, tāpēc ievērojami mazinās iespējamā kḷūda, novērtējot uzturvielas saistību ar slimību [Jenab, 2009];

2) biomarķieri labāk atspoguḷo lignānu koncentrāciju audos un iespējamo protektīvo ietekmi nekā to daudzums uzturā, jo ir lielas atšksirības starp indivīdiem absorbcijā un metabolismā;

3) biomarķierus var lietot pētījumos, kad lignānu daudzumu uzturā nav iespējams noteikt [Pérez-Jiménez, 2010]. Enterolignānus plazmā un urīnā uzskata par vispiemērotāko rīku, kas var būt lietojams kā uztura lignānu biomarķieris cilvēku populācijas pētījumos. To koncentrācija ir daudz pētīta dažādu pasaules reǵionu populācijās, kā arī saistībā ar dažādu slimību risku.

\section{Lignānu iedarbība}

ENL un mazākā mērā END kavē 5 $\alpha$-reduktāzi, enzīmu, kas pārvērš testosteronu par 5 $\alpha$-dihidrotestosteronu, biologiski visaktīvāko androgēnu. ENL un END kavē arī 17ß-hidroksisteroīdu dehidrogenāzi. Maisījums no septiņiem komponentiem, kas satur gan izoflavonus, gan lignānus, katru $10 \mu \mathrm{M}$ koncentrācijā, kavē $5 \alpha$-reduktāzi par 77\% un 17ß-hidroksisteroīdu dehidrogenāzi par 94\%. Fitoestrogēnu maisījums kavēja

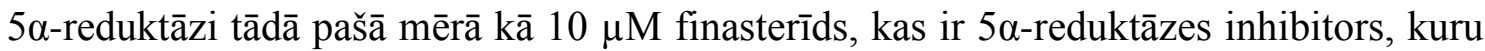
lieto labdabīgas priekšdziedzera hiperplāzijas (LPH) ārstēšanā [Adlercreutz, 2007].

ENL palielina plazmas androstandiola glikuronīda līmeni vīriešiem, un šajā procesā iespējama mijiedarbība ar CYP19 gēnu [Low, 2005]. Teorētiskais mehānisms varētu būt tāds, ka lignāni aizņem 5 $\alpha$-dihidrotestosterona vietu SHBG, un $5 \alpha$-dihidrotestosterons tiek pārveidots ādā un aknās par androstandiola glikuronīdu. 
Pētîts, ka cilvēku preadipocītos lignāni kavē 17ß-hidroksisteroīdu dehidrogenāzes 1. tipu (enzīmu, kas mazina estrogēnu veidošanos) dažādās pakāpēs. Visspēcīgāk kavēja didemetoksimatairezinols. Lignāni ir vāji inhibitori, tomēr uzturs, kas bagāts ar pilngraudu produktiem, sakņaugiem, citiem dārzeņiem, ogām, aug̣̦iem, nodrošina pietiekamu koncentrāciju, piemēram, taukos un vēža šūnās, lai mazinātu androstēndiona pārvēršanu par estronu, tādējādi mazinot hormonāli atkarīgu vēžu risku [Adlercreutz, 2007].

Tiek pētīti arī citi iespējamie lignānu darbības mehānismi. Lignāniem ir antioksidatīva aktivitāte in vitro, kas var kavēt DNS bojājumu. Sezama sēklu lignāni paaugstina tokoferola līmeni asinīs [Saarinen , 2010].

Lignāni un priekšdziedzera vēzis. Apkopojot minēto lignānu iedarbību, tiek izveidota uztura lignānu protektīvo darbības mehānismu shēma (skat. 1.7. attēlu) [Adlercreutz, 2002]:

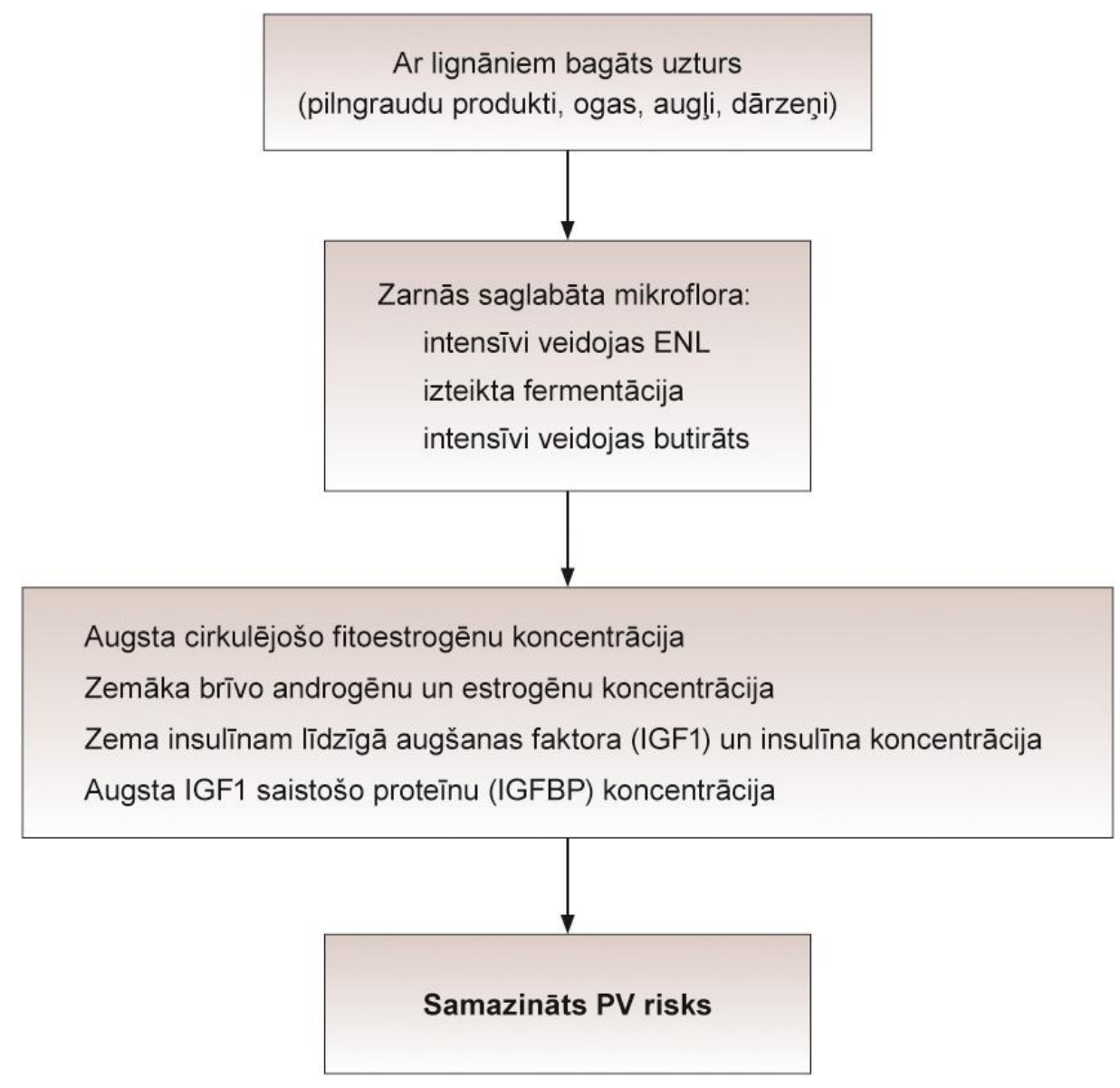

1.7. att. Lignānu protektīvo darbības mehānismu shēma [Adlercreutz, 2002] 
Pēdējos gados pētīti vēl citi lignānu antikancerogēnās darbības mehānismi, tādi kā apoptozes veicināšana; $5 \alpha$ reduktāzes aktivitātes kavēšana; antioksidatīva iedarbība, pasargājot DNS no skābekḷa un slāpekḷa radikāḷu iedarbības, tokoferola koncentrācijas paaugstināšanās. Lignānu darbība nav kā tiešiem estrogēnu agonistiem, koncepts par selektīvu estrogēnus modulējošu darbību (SERM) vēl jāturpina pētīt [Saarinen, 2010].

Epidemiologisko pētījumu rezultāti ne vienmēr apstiprina lignānu protektīvo darbību. Gadījumu kontroles un prospektīvos pētījumos analizēta PV riska korelācija ar seruma vai plazmas ENL koncentrāciju, ENL koncentrāciju urīnā vai specifisku lignānu daudzumu uzturā. Rezultāti bija heterogēni. Lielākajā daḷā pētījumu neatrada statistiski ticamu korelāciju starp ENL koncentrāciju serumā, plazmā, urīnā vai lignānu daudzumu uzturā un PV risku vai progresēšanas pakāpi [McCann, 2005; Hedelin, 2006; Heald 2007; Travis, 2009a; Park, 2009]. Lignānu daudzums uzturā bija no 500 g/d līdz 3000 $\mu \mathrm{g} / \mathrm{d}$ atkarībā no ietverto lignānu veidu skaita (no diviem līdz sešiem lignānu veidiem) [Strom, 1999; Hedelin, 2006]. Visos pētījumos ENL koncentrācija serumā vai plazmā bija mazāka par 20 nmol [Stattin, 2004; Heald, 2007; Travis, 2009a]. Iespējams, ka saistību nevarēja konstatēt, jo bija pārāk zema ENL koncentrācija, kā arī pārāk mazas uzturā esošo lignānu daudzuma atšksirības, salīdzinot populāciju kvartiles. Turklāt vienreizēja ENL noteikšana var neatspogulot lignānu daudzumu uzturā ilgstošā laika periodā. Zināms arī, ka ENL koncentrācija serumā vai plazmā nav atkarīga tikai no lignānu daudzuma uzturā, bet arī no citiem faktoriem, kas ne vienmēr tika ņemti vērā (piemēram, antibiotiku lietošana). Intervences pētījumos, lietojot linsēklas, sezama sēklas, rudzu pilngraudu maizi, ENL koncentrācija palielinās ievērojami vairāk, pat pārsniedz 300 nmol [Kuijsten, 2005a; Penalvo, 2005b]. Vienreizēja 50 g sezama sēklu deva palielina ENL koncentrāciju virs $1 \mu \mathrm{M}$ (no nanomolekulārām līdz mikromolekulārām koncentrācijām) [Peñalvo, 2005]. Tāpēc, iespējams, epidemioloǵiskie pētījumi nenorāda, ka lignāniem nav protektīvas iedarbības, bet gan to, ka lignānu daudzums uzturā ilgstošā laika periodā ir pārāk niecīgs [Saarinen, 2010].

Lignānu iedarbība ir pētīta intervences pētījumos gan attiecībā uz PV primāro, gan sekundāro prevenciju. Linsēklu lietošana (30 g/d) pētīta kopā ar diētu ar samazinātu tauku daudzumu (tauku enerḡêtiskā vērtība $\leq 20 \%$ no kopējā kcal daudzuma). Pētīta šāda uztura ietekme uz nemalignu priekšdziedzera epitēliju ar priekšdziedzera intraepiteliālās neoplāzijas izmaiņām pacientiem, kam plānota atkārtota priekšdziedzera biopsija, un tika konstatēta PSA līmeņa un proliferācijas pakāpes mazināšanās [DemarkWahnefried, 2004]. Pacientiem ar diagnosticētu PV diēta ar linsēklām (30 g) un zemu 
tauku saturu $(\leq 20 \% \mathrm{kcal}) 34$ dienas pirms operācijas samazināja testosterona, brīvo androgēnu līmeni, audzēja proliferācijas indeksu, holesterīna līmeni, kā arī paaugstinājās apoptozes indekss [Demark-Wahnefried, 2001]. Citā pētījumā tika konstatēts, ka linsēklu lietošana (30 g 30 dienas) mazina audzēja proliferācijas pakāpi, bet neietekmē apoptozi, kā arī seruma PSA, SHBG, testosteronu un IGF-1 [DemarkWahnefried, 2008]. Kopsavilkumā - intervences pilotpētījumi liecina par lignānu potenciālu, ietekmējot PV norisi, bet visos šajos pētījumos ir mazs dalībnieku skaits (starp desmit un dažiem desmitiem), kas prasa piesardzību rezultātu interpretācijā un turpmākus pētījumus.

\subsubsection{Pilngraudu produkti, rudzu maize un šķiedrvielas}

Epidemiologiskie pētījumi rāda saistību starp lielāku pilngraudu daudzumu uzturā un samazinātu risku saslimt ar tādām ar uzturu saistītām slimībām kā koronārā sirds slimība, arteriālā hipertensija, aptaukošanās, 2. tipa cukura diabēts, kā arī samazinātu dažu lokalizāciju vēžu, tostarp arī priekšdziedzera vēža risku [Slavin, 2004; Flight, 2006; Malik, 2007; De Munter, 2007; Anderson, 2009]. Šo protektīvo iedarbību nodrošina tieši t.s. šķiedrvielu komplekss un protektīvo vielu sinerǵiskā darbība [Slavin, 2003; Adlercreutz, 2007; Anderson, 2009].

Pētīti vairāki iespējami šķiedrvielu antikancerogēnās iedarbības mehānismi. Šķiedrvielām bagāta diēta palielina feču apjomu, atšksaida fēču saturu un tādējādi ietekmē estrogēnu enterohepatisko cirkulāciju, jo mazina to enzīmu koncentrāciju (baktēriju producētās $\beta$ glikuronidāzes aktivitāti), kas veic estrogēnu konjugātu hidrolīzi (aprakstīts nodaḷā: Priekšdziedzera vēzis un androgēni, estrogēni). Tā kā estrogēni nevar zarnā reabsorbēties konjugētā veidā, šķiedrvielas mazina estrogēnu līmeni plazmā un palielina estrogēnu ekskrēciju ar fēcēm. Aprakstīta arī saistība starp šķiedrvielām bagātu uzturu un augstāku SHBG koncentrāciju. SHBG savukārt saista brīvos estrogēnus, regulē estradiola biopieejamību un ir saistīts ar mazāku PV risku [Roddam, 2008]. Šķiedrvielu ietekme uz enterohepatisko cirkulāciju atkarīga arī no šķiedrvielu veida. Apmēram 50\% no konjugētajiem estrogēniem no aknām tiek izdalīti žultsceḷos un reabsorbēti zarnu traktā. Tieši graudaugu nešķīstošās šķiedrvielas paaugstina estrogēnu fekālo ekskrēciju. Augḷu, dārzeņu šķiedrvielas, kas pārsvarā ir šķīstošās šķiedrvielas, estrogēnu enterohepatisko cirkulāciju ietekmē mazāk [Aubertin-Leheudre, 2008a]. Tas ir būtiski, jo dažādās valstīs šķiedrvielu avoti atšķiras. 
Vēl cita šķiedrvielu ietekme - šķiedrvielas sekmē estrogēnu elimināciju no zarnu trakta, jo saistās ar estrogēniem, kā arī šķiedrvielas paātrina intestinālo tranzītu [Monroe, 2007; Aubertin-Leheudre, 2008a].

Šķiedrvielām bagāts uzturs arī satur daudz lignānu, kas, iespējams, arī mazina PV risku [Adlercreutz, 2002]. Pilngraudu rudzu produkti satur daudz lignānu, to lietošana uzturā palielina ENL producēšanu un stimulē butirāta veidošanos zarnu traktā. Sviestskābei ir pretvēža aktivitāte, un tā piedalās pilngraudu (rudzu) šksiedrvielu kompleksa darbībā.

Iespējamas arī, ka pektīns, polisaharīdu šķīstošais komponents, palielina apoptozi PV šūnās [Jackson, 2007].

Apkopojot pētījumu datus par uzturu, kas satur daudz pilngraudu un šķiedrvielu, var konstatēt iespējamo darbības mehānismu - šksiedrvielām un og̣̦hidrātiem bagāts uzturs nodrošina izteiktus fermentācijas procesus un butirāta, ENL veidošanos zarnās, kā arī kancerogēno žultsskābju esterifikācijas palielināšanos. Rezultātā plazmā paaugstinās SHBG, kas samazina brīvo, biologiski aktīvo dzimumhormonu daudzumu cirkulācijā. Antibiotiku lietošana izjauc normālo mijiedarbību starp uzturu un zarnu mikrofloru un līdz ar to arī saistību starp šķiedrvielām uzturā un slimību risku. Vienlaikus ar SHBG līmeņa palielināšanos samazinās insulīna un IGF1 koncentrācija, paaugstinās IGFBP un samazinās taukskābju oksidācija. Viena no nozīmīgākajām lignānu ietekmēm ir iedarbība uz intracelulāro steroīdu hormonu metabolismu, konkurējot ar steroīdiem par saistību ar sulfatāzēm.

Rudzu maize, salīdzinot ar citiem graudaugiem, satur daudz šķiedrvielu un citu biologiiski aktīvu vielu: lignānus, alkilrezorcīnus (AR), fitīnskābi, E vitamīnu, tiamīnu ( $\mathrm{B}_{1}$ vitamīnu), riboflavīnu ( $\mathrm{B}_{2}$ vitamīnu), niacīnu ( $\mathrm{PP}$ vai $\mathrm{B}_{3}$ vitamīnu), folātus, cinku, dzelzi, mangānu, magniju un selēnu. Visas šīs aktīvās vielas graudā atrodas galvenokārt apvalka dạ̦ā, kā arī dīglī (1.8. attēls).

Rudzu graudi satur 15-17\% šķiedrvielas sausnā. $20 \%$ no šķiedrvielām ir šķīstošās šķiedrvielas, pārējās - nešķīstošās. Nešķīstošās šķiedrvielas pārsvarā ir celuloze un lignīns, šķisstošās - arabinoksilāni un $\beta$ glikāni. Rudzu maize satur 6-15 g šķiedrvielu 100 g produkta, Latvijā 5-9 g šķiedrvielu 100 g produkta. Latvijā ražotajai maizei šķiedrvielu daudzumu visbiežāk nenosaka, bet aprēķina. Latvijā rutīnā nosaka tikai nešķisstošo šķiedrvielu daudzumu. Tā kā bioloǵiski aktīvās vielas (tostarp lignāni, AR) ir pārsvarā lokalizētas grauda apvalka daḷā un cieši saistītas ar šķiedrvielām, runa ir par rudzu šksiedrvielu kompleksu. Tieši šim kompleksam piemīt nozīmīgākā bioloǵiskā 
ietekme uz veselību. Dienā apēdot 150-200 g rudzu maizes, mēs saņemam 10-20 g šķiedrvielu (kas ir puse no nepieciešamā daudzuma dienā) un ievērojamu daļu no minētajiem vitamīniem un minerālvielām, kā arī lignānus.

\section{Grauds un tã bioaktivie komponenti}

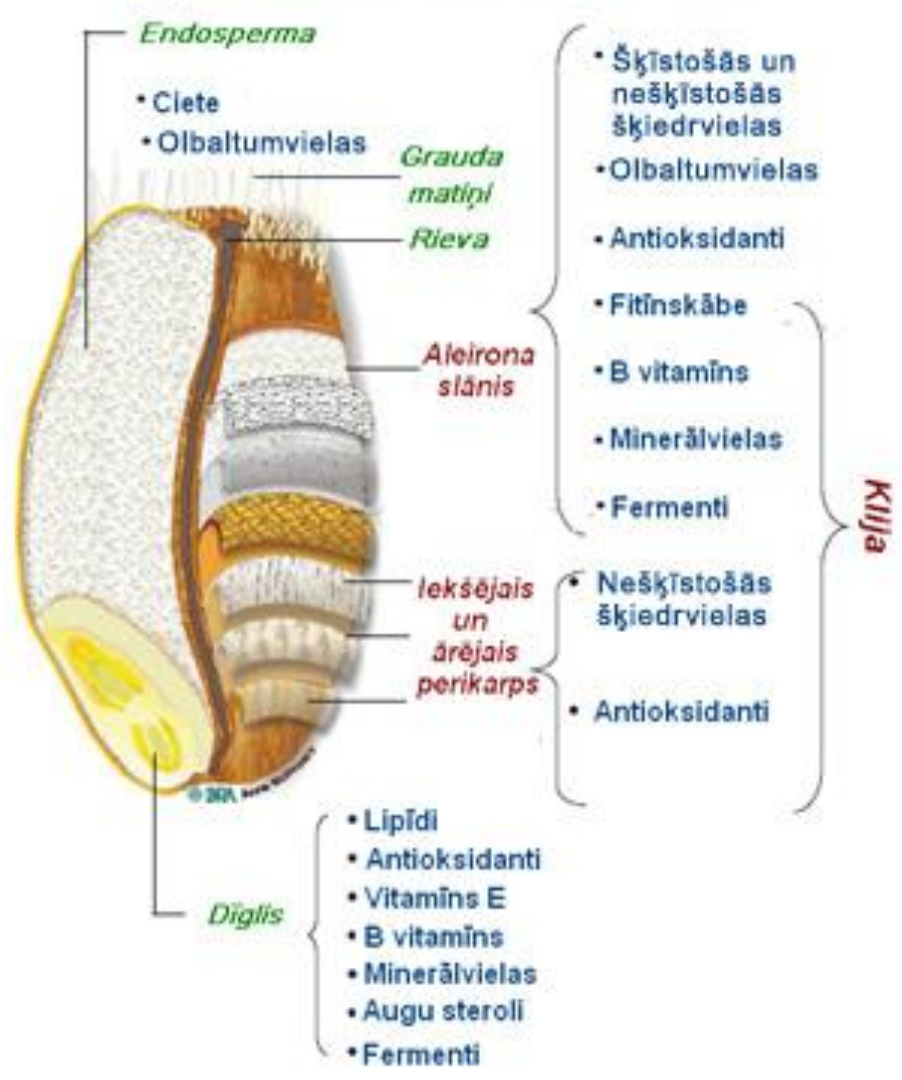

1.8. att. Grauda uzbūve [Van der Kamp, 2012]

PV riska saistība ar šķiedrvielām uzturā pētīta gan gadījumu kontroles pētījumos, gan prospektīvos pētījumos [Pelucchi, 2004; McCann, 2005; Walker, 2005; Suzuki, 2009]. Tiek pētìta arī dažādu produktu šķiedrvielu ietekme. Dati ir pretrunīgi, daḷa pêtījumu saistība nav atrasta. Ir pētījumi, kas rāda saistību starp mazāku PV risku un sakṇu dārzeņu şķiedrvielu lietošanu [Pelucchi, 2004 ] vai augḷu šķiedrvielu lietošanu [Suzuki, 2009]. Nesen liels pētījums apstiprināja, ka PV riska mazināšanā svarīga nozīme ir rudzu maizes lietošanai tieši pusaudža gados [Torfadottir, 2012].

Ir bijuši arī daži nelieli intervences pētījumi ar rudzu maizi. Vienā pētījumā priekšdziedzera vēža pacienti trīs nedēlas saņēma 275 g rudzu maizes ar augstu šķiedrvielu saturu (16 g/100 g maizes), kontroles grupa saṇēma kviešu maizi. 
Rudzu maizes grupā konstatēja apoptozes indeksa palielināšanos [Bylund, 2003]. Citā intervences pētījumā PV pacienti saņēma pilngraudu rudzu maizi un produktus ar rudzu klijām, kontroles grupa saṇēma kviešu maizi un tā produktus ar pievienotu celulozi. Rudzu maizes grupā, salīdzinot ar kontroles grupu, samazinājās PSA, insulīna līmenis plazmā un C peptīda līmenis urīnā [Landberg, 2010].

\subsubsection{Alkilrezorcīni - pilngraudu marķieri}

Zināms, ka epidemioloǵiskajos pētījumos par uzturu nav iespējams izvairīties no problēmām, kas saistītas ar precīzu uzṇemtā uztura novērtēšanu. Novērtējot pilngraudu produktu daudzumu uzturā, rodas papildu problēmas, piemēram, l̦oti plašs produktu klāsts, dažādas pārstrādes metodes. Tas rada problēmas novērtēt pilngraudu daudzumu produktos gan patērētājam, gan zinātniekiem [Seal, 2006]. Lietojot biomarķierus, var ievērojami mazināt šīs nepiln̄̄bas, novērtējot pilngraudu produktu daudzumu uzturā. Biomarķieru lietošana ļauj novērtēt pilngraudu daudzumu uzturā, izslēdzot subjektīvo faktoru. Biomarķierus var lietot pētījumos saistībā ar uzņemtā uztura datiem vai pat bez tiem gadījumos, kad uzņemtā uztura dati ir ar mazāku ticamību (piemēram, vecāka gadagājuma cilvēki bieži nespēj adekvāti sniegt datus par savu uzturu) vai nav pieejami (asins preparātu lietošana no asin̄̄m, kas uzglabātas asins bankās) [Wild, 2001]. Turklāt pilngraudu produktu biomarķierus var lietot arī ar mērḳi novērtēt līdzestību intervences pētījumos (kad uzturā tiek palielināts pilngraudu produktu daudzums ilgākā laika periodā). Alkilrezorcīni (AR) tiek uzskatīti par biomarķieriem pilngraudu produktu daudzumam uzturā.

AR ir vieni no nozīmīgākajiem fenoliem graudaugos. Ķīmiski AR ir 1,3-dihidroksibenzola atvasinājumi, kam benzola gredzena 5. pozīcijā ir alkilgrupa ar nepāra skaitu oglekḷa atomu (1.9. att.). Graudos tie galvenokārt satur piesātinātās alkilķēdes ar 15-27 oglekḷa atomiem [Ross, 2004].

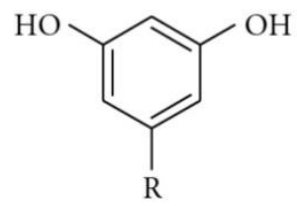

(a)

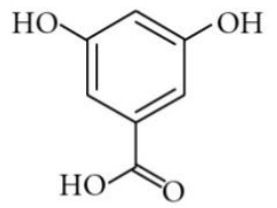

(b)<smiles>O=C(O)Cc1cc(O)cc(O)c1</smiles>

(c)

1.9. att. Alkilrezorcīnu pamatstruktūra (a) un to metabolītu struktūra:

3,5-dihidroksibenzokābes (DHBA) (b) un 3-(3,5-dihidroksifenil) propānskābes (DHPPA) (c) struktūra [Ross, 2012a] 
Alkilķēes pārsvarā ir piesātinātas (>80\%) [Ross, 2003a], lai gan rudzos nepiesātinātie AR veido 10-15\% [Ross, 2003b]. Dažādu piesātināto homologu proporcijas atšķiras dažādiem graudaugiem, un tos lieto, lai diferencētu attiecīgo graudaugu ipatsvaru produktos [Chen, 2004]. Attiecība C17:0/C21:0 kviešiem ir aptuveni 0,1 , bet rudziem 1 . Šo attiecību lieto kā metodi, lai noteiktu, vai graudaugu produkts satur vairāk rudzu vai kviešu, vai maisījumu no abiem graudiem [Chen, 2004; Landberg, 2006]. AR daudzums uzturā pētīts pārsvarā Eiropas valstīs, un tas variē no 12 mg Lielbritānijā līdz 40 mg Somijā [Ross, 2005].

AR ir lokalizēti graudu ārējā apvalkāa (iekšējā perikarpā, hialīna slānī un aizsargājošā apvalkāa - plēksnē), bet nav sastopami endospermā (grauda iekšējā dal̦ā) [Landberg, 2008a]. Tāpēc AR ir sastopami tikai pilngraudu produktos vai šo graudu klijās, bet gandrīz nav atrodami rafinētajos miltos un izstrādājumos no rafinētajiem miltiem. Galvenie AR avoti uzturā ir kvieši un rudzi. AR vēl sastopami tritikālē (rudzu un kviešu hibrīds), ko cilvēki uzturā parasti neizmanto, un ļoti nelielos daudzumos arī miežos, citos produktos to gandrīz nav [Ross, 2003a; Chen, 2004]. AR daudzums produktos ievērojami variē (1.2. tabula). Produktu apstrāde nemaina AR koncentrāciju [Ross, 2003a].

AR bioloǵiskā aktivitāte vairāk pētîta in vitro, to nosaka AR spēja integrēties membrānās un kavēt enzīmus [Stasiuk, 2010]. Aprakstīta AR antikancerogēnā ietekme in vitro [Ross, 2004] un antioksidatīva efektivitāte in vivo [Kozubek, 1995]. Jaunākie pētījumi rāda, ka AR varētu būt vienas no aktīvajām substancēm zarnu vēža prevencijā [Zhu, 2011]. Gadījumu kontroles pētījumā konstatēts, ka pacientēm ar krūts vēzi ir zemāka AR metabolītu koncentrācija plazmā un urīnā nekā kontroles grupai [AubertinLeheudre, 2010a].

AR var noteikt graudos un graudaugu produktos [Ross, 2003a; Chen, 2004], kā arī plazmā intaktus, saistītus ar lipoproteīniem [Ross, 2004; Linko-Parvinen 2007], un eritrocītu membrānās [Linko, 2005]. AR metabolītus 3,5-dihidroksibenzoskābi (DHBA) un 3-(3,5-dihidroksifenil)propānskābi (DHPPA) var noteikt urīnā [AubertinLeheudre, 2008b; Guyman, 2008] un plazmā [Söderholm, 2009; Aubertin-Leheudre, 2010b] (1.2. tabula).

AR tiek uzskatīti par pilngraudu pakāpes marķieriem rudzu un kviešu produktos [Ross, 2003a; Chen, 2004; Landberg, 2006; Kulawinek, 2008]. AR var arī lietot, lai pārbaudītu bezglutēna graudaugu produktu iespējamo piesānnojumu ar glutēnu saturošajiem graudaugiem (kviešiem, rudziem, miežiem), jo pat baltie rafinētie milti 
satur nelielu AR daudzumu $(20-50 \mu \mathrm{g} / \mathrm{g})$ un tos var konstatēt ar jutīgām izmeklēšanas metodēm (GC-MS; HPLC). Arī AR noteikšanu plazmā var lietot, lai pārbaudītu, vai celiakijas slimnieki ievēro bezglutēna diētu [Ross, 2012a].

AR uzskata arī par biomarķieriem pilngraudu rudzu un kviešu produktu daudzumam uzturā [Linko, 2002; Ross, 2004; Aubertin-Leheudre, 2008b; Landberg 2008b]. 1.2. tabulā atspoguḷoti galvenie biomarķieru kritēriji un AR atbilstība tiem.

1.2. tabula

Alkilrezorcīnu kā biomarķieru validēšana (adaptēts no [Ross, 2012a])

\begin{tabular}{l|l}
\hline $\begin{array}{l}\text { Kvantitatīvās analītiskās metodes } \\
\text { AR noteikšanai graudos un ēdienos }\end{array}$ & GC \\
KPLC \\
Kalorimetrija
\end{tabular}

DHBA un DHPPA var noteikt plazmā un urīnā

\begin{tabular}{|c|c|}
\hline Farmakokinētika & $\begin{array}{l}\text { Tmax 1: 2,6 h; Tmax2: } 6,7 \text { h; T1/2: 4,8 h } \\
\text { Metabolīiti plazmā: Tmax: } 6 \text { h; T1/2: 10-16 h } \\
\text { Metabolīiti urīnā: Tmax: } 6 \text { h; T1/2: 10-12 h }\end{array}$ \\
\hline $\begin{array}{l}\text { AR koncentrāciju plazmā } \\
\text { ietekmējoši faktori }\end{array}$ & $\begin{array}{l}\text { Dzimums: vīriešiem augstāka koncentrācija } \\
\text { Triglicerīdi, lipoproteīni }\end{array}$ \\
\hline $\begin{array}{l}\text { Lietojums klīniskajos un } \\
\text { epidemiologiskajos pētījumos }\end{array}$ & $\begin{array}{l}\text { Surogātmērījums pilngraudu produktiem uzturā } \\
\text { Uzṇemtā uztura datu validācija } \\
\text { Biomarkịieris līdzestībai intervences pētîjumos }\end{array}$ \\
\hline
\end{tabular}

HPLC-CAD - augstas izšķirtspējas šķidruma hromatogrāfija ar kulonometrisko detektoru

GC-MS - gāzu hromatogrāfija-masspektrometrija 
Tā kā AR sastopami galvenokārt tikai kviešu un rudzu graudu ārējā apvalkā, tie var būt labi biomarķieri pilngraudu kviešu vai rudzu produktiem uzturā vai tikai šo graudu kliju daudzumam uzturā (gadījumos, kad rafinēto miltu izstrādājumiem pievieno klijas). Turklāt pārtikas ražošanas procesi nemazina AR koncentrāciju. AR cilvēkiem labi uzsūcas - tievajās zarnās, izmantojot limfātisko sistēmu, uzsūcas 60\% [Ross, 2003b], kaut zināms, ka augstākas AR koncentrācijas gadījumā uzsūkšanās pakāpe ir zemāka [Landberg, 2009a]. Pēc absorbēšanās AR tiek iekļauti eritrocītos un tiek transportēti plazmas lipoproteīnos (pārsvarā augsta blīvuma lipoproteīnos) [LinkoParvinen, 2007] un uzkrāti taukaudos [Jansson, 2010]. AR tiek metabolizēti, oksidējoties alkilksēei par diviem galvenajiem metabolītiem DHBA un DHPPA, kas arī var būt izmantojami kā biomarķieri [Ross, 2012a]. AR eliminācijas pusperiods ( $\left.T^{1} / 2\right)$ plazmā ir aptuveni 5 stundas, bet līkne var variēt atkarībā no tā, vai AR uzturā tiek uzṇemti regulāri vai tā ir atsevišksa deva pēc perioda, kura laikā AR nav lietoti uzturā (anglu val. - „washout”) [Ross, 2012a]. AR metabolītiem T1² plazmā ir 10-16 stundas [Söderholm, 2009] un urīnā 10-12 stundas [Söderholm, 2011]. Regulāri lietojot AR saturošus produktus uzturā, tukšas dūšas AR koncentrācija ir augstāka, savukārt tā ātri mazinās, ja uzturā ir maz vai nav nemaz AR saturošu produktu [Ross, 2012a]. Tāpēc neregulāra pilngraudu produktu lietošana varētu mazināt AR kā biomarķieru lietošanas nozīmīgumu, tomēr visbiežāk graudaugu lietošanas paradumi cilvēkiem ir stabili. Risinājums varētu būt AR noteikšana taukaudos [Jansson, 2010].

Pētot AR kā pilngraudu produktu uzturā biomarḳiera atbilstîbu, konstatēta cieša korelācija starp graudaugu šksiedrvielu daudzumu uzturā un AR koncentrāciju plazmā, kā arī AR metabolītu koncentrāciju plazmā un urīnā [Aubertin-Leheudre, 2008b; 2010 Guyman, 2008; Söderholm, 2009]. Visos intervences pētījumos tika konstatēts, ka plazmas AR un AR metabolītu koncentrācija pieaug, palielinot pilngraudu kviešu/rudzu daudzumu uzturā, kaut arī pastāv individuālas variācijas [Ross, 2012 a,b] (1.10. att.). 


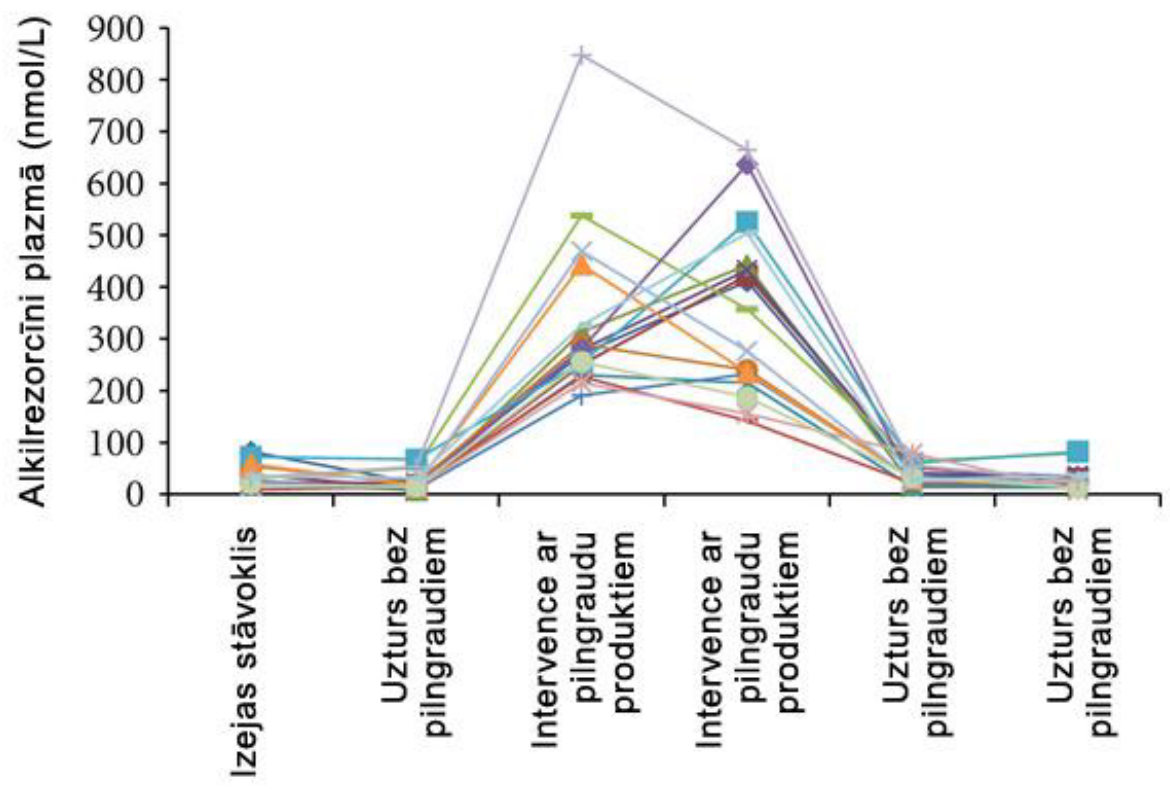

\subsection{0. att. Plazmas AR individuālās variācijas kontrolētos apstākḷos. Intervences pētījumā pilngraudu produkti nodrošina $62 \mathrm{mg}$ AR. Katrs posms aizṇēma 1 nedēlu [Ross, 2012a]}

Vairākkārt konstatēts, ka intervences apstākļos, ar uzturu uzņemot noteiktu AR daudzumu, starpklašu korelācija bija cieša $(0,88-0,9)$, bet, saņemot ikdienas uzturu, korelācija bija vidēja $(0,42-0,48)$.

Pêtījumos, kur tika pētīta korelācija starp AR un to metabolīitiem bioloǵiskajos šķidrumos un uzṇemtā uztura datiem (AR daudzums uzturā, pilngraudu produktu daudzums uzturā, graudaugu šķiedrvielu daudzums uzturā), korelācija bija robežās no 0,25 līdz 0,58 atkarībā no metodēm, kas tika lietotas, lai novērtētu uzņemto uzturu. Lietojot standarta uztura biežuma aptaujas anketu, korelācija bija $<0,4$, lietojot uztura dienasgrāmatas (izmantojot svarus, lai novērtētu uztura daudzumu - 0,32-0,52, un, izmantojot uztura biežuma aptaujas anketas, kas speciāli izveidotas, lai novērtētu pilngraudu produktus uzturā, $-0,5-0,58$ [Ross, 2012a].

AR lietoti arī kā surogātmarķieri pilngraudu produktu daudzumam uzturā [Landberg, 2011] un arī kā līdzestîbas rādītāji intervences pētījumos, kad nereti ir loti sarežǵîiti izsekot dalībnieku līdzestībai [Ross, 2012a]. Pētīta AR koncentrācijas paaugstināšanās plazmā pēc pilngraudu produktu (vai AR daudzuma) pievienošanas uzturā. Dāṇu populācijā konstatēts, ka pēc $100 \mathrm{~g}$ rudzu maizes (vai $70 \mathrm{mg} \mathrm{AR}$, tos aprēķinot, zinot to daudzumu dāņu rudzu maizē) lietošanas AR plazmā pieaug par 85 nmol/L [Landberg, 2011]. 
AR homologu C17:0 un C21:0 attiecība ir indikatīva, izvērtējot rudzu un kviešu produktus, un to var izmantot, arī izvērtējot AR cilvēka biologiskajos šķidrumos [LinkoParvinen, 2007], kaut gan arī pēc rudzu lietošanas š̄ attiecība ir ievērojami mazāka par 1. Parasti tā ir ap 0,3. To var skaidrot ar garāko ķēžu ātrāku metabolismu. Dati rāda, ka C17:0/ C21:0 attiecība ir indikatīva, lai izvērtētu AR avotus intervences pētījumos. C17:0/ C21:0 attiecība, lielāka par 0,15, norāda uz rudzu produktu lietošanu uzturā [Ross, 2012a].

Par citiem faktoriem, kas ietekmē AR un to metabolītu koncentrāciju, ir maz datu. Zināms, ka vīriešiem ir augstāka AR un to metabolītu koncentrācija [Ross, 2012b], par korelāciju ar lipīdu līmeni dati ir pretrunīgi [Landberg, 2011].

Izmantojot AR kā biomarķierus, jāṇem vērā vairāki nosacījumi, lai rezultāti būtu vērā ņemami [Ross, 2012a]:

1) novērtējot $\mathrm{AR}$ daudzumu uzturā, jānosaka AR daudzums lokālajos produktos, jo vērtības var atšksirties no paredzamām vērtībām;

2) jāreǵistrē pēdējās maltītes laiks. Lai novērtētu pilngraudu produktu daudzumu uzturā, vēlams izmeklēt tikai paraugus, kas savākti tukšā dūšā;

3) AR relatīvi ātri reaǵē uz izmaiṇām uzturā (pilngraudu kviešu/rudzu produktu lietošana), izmaiņas diētā vienu nedēḷu kardināli maina plazmas AR koncentrācijas. Var secināt, ka pastāv cieša korelācija starp vidējo AR daudzumu uzturā un vidējo AR metabolītu koncentrāciju bioloǵiskajos šķidrumos. AR koncentrācija biologiskajos šķidrumos ir piemērota, lai novērtētu pilngraudu produktu daudzumu uzturā atsevišş̧iem indivīdiem, bet augstāka ticamības pakāpe ir, novērtējot pilngraudu kviešu un rudzu daudzumu uzturā lielākā populācijā.

\subsubsection{Tauki, zivis un gaḷa uzturā}

Tauki uzturā arī pieder pie iespējamiem PV riska faktoriem. Lielākā daḷa gadījumu kontroles pētījumu norāda pozitīvu saistību starp tauku kopējo daudzumu uzturā un PV risku, savukārt vairāki lieli prospektīvi pētījumi rāda, ka saistība nepastāv [Moyad, 2002; Bostwick, 2004; Chan, 2005; Tewari, 2012].

Tiek pētīts, ka ne tikai kopējais tauku daudzums, bet tieši tauku veids ietekmē PV attīstību. Polinepiesātinātās taukskābes (PNTS), iespējams, paaugstina PV risku. Tiek pētīta atsevišksu taukskābju ietekme. Iegūt objektīvus datus par to, kādus taukus 
uzturā lieto vecāki vīrieši, ir sarežǵīti, jo ļoti bieži viņi nezina, kādi tauki izmantoti ēdiena gatavošanā un kādu margarīnu ziež uz maizes. Par linolskābi (C-18 $\omega-6)$, kas tiek plaši izmantota rietumvalstu diētā (saulespuķu, kukurūzas u.c. augu ellıās), ir pretrunīgi dati. Daži pētījumi norāda risku mazinošu, citi - risku palielinoši efektu, citi pētījumi - saistības trūkumu [Laaksonen, 2004; Leitzmann, 2004a; Wallström, 2007].

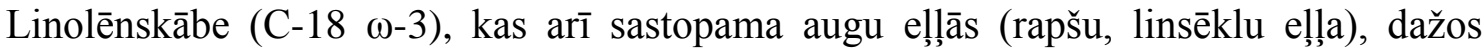
pētījumos palielina PV risku, citi pētījumi rāda saistības trūkumu [Astorg, 2004;

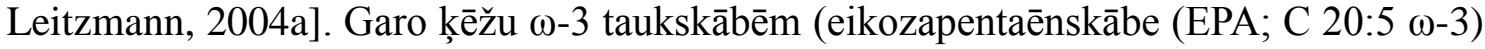
un dokozaheksaēnskābe (DHA; C 22:6 $\omega$-3) ir pretiekaisuma ietekme, tās ir iesaistītas prostaglandīnu sintēzes procesos un ietekmē arī proliferācijas un angioǵenēzes procesus. To galvenais avots uzturā ir treknas zivis, un dažos pētījumos zivju lietošanai per se vērojams protektīvs efekts [Astorg, 2004; Leitzmann, 2004a]. Savukārt liels prospektīvs pētījums Zviedrijā rādīja pozitīvu saistî̉bu starp EPA un DHA uzturā un PV risku [Wallström, 2007]. Skaidrojums varētu būt Baltijas jūras piesārņojums ar polihlorbifeniliem, kas tiek uzskatīti par endokrīnās sistēmas „sagrāvējiem”, ietekmējot androgēnu un estrogēnu ietekmi organismā [Brouwer, 1999; Sjödin, 2000]. Nesenā metaanalīzē konstatēts, ka zivju lietošanai ir nulles vai vāja saistība ar kopējo PV incidenci, bet pastāv cieša negatīva korelācija starp zivju lietošanu un agresīvu PV [Szymanski, 2010].

Atsevišşu pētījumu rezultāti rāda, ka piesātinātie tauki uzturā ir saistīti ar palielinātu PV incidenci [Taille, 2001]. Tieši dz̄ivnieku tauki uzturā, iespējams, palielina PV risku [Schuurman, 1999]. Tauki uzturā, iespējams, palielina tieši agresīva PV risku [Tewari, 2012].

Gaļa ir viens no būtiskākajiem piesātināto tauku avotiem uzturā, bet gal̦as ietekme uz PV risku tiek pētīta arī citos aspektos. Daži pētījumi norāda, ka gaḷas lietošana, īpaši sarkanās gaļas lietošana un pārstrādātas gaļas (žāvēta, cepta, kūpināta) lietošana, palielina PV risku. Tomēr citi pētîjumi to neapstiprina [Alexander, 2010; Leitzmann, 2012]. Ir pētīta arī ēdiena gatavošanas veida ietekme. Gaļu (arī zivis) grilējot un cepot, veidojas policikliskie aromātiskie ogḷūdeņraži un heterocikliskie amīni [Shirai, 2002]. Ražojot gaḷas izstrādājumus (šķiņķus, desas), kā konservējošo vielu un sārtās krāsas nodrošināšanai pievieno nātrija nitrītu, no kā organismā veidojas nitrozamīni. Šīs vielas koncentrējas priekšdziedzerī, kur palielinās brīvo radikāḷu veidošanās, un var veicināt kancerog̣enēzi [Cheetham, 2011]. Marinējot gaḷu etiķ̄î, olīvellıāa, pievienojot protektīvās garšvielas (ķiploku, kurkumu, rozmarīnu), tiek 
mazināta kancerogēno vielu veidošanās cepšanas laikā. Arī kāpostu dzimtas dārzeņu lietošana neitralizē heterociklisko amīnu iedarbību uz organismu [Cheetham, 2011]. Iespējamais tauku darbības mehānisms, iedarbojoties uz PV attīstības procesu, ir ietekme uz hormonu metabolismu. Tauki palielina endogēno estrogēnu uzsūkšanos zarnā, it īpaši uzturs ar lielu tauku daudzumu un mazu šķiedrvielu daudzumu palielina estrogēnu koncentrāciju urīnā un asin̄̄s un mazina koncentrāciju fēcēs [AubertinLeheudre, 2008a]. Savukārt uzturs ar zemu tauku saturu samazina seruma estradiola līmeni [Tsuji, 2012]. Ir pētîjumi, kas rāda, ka pārmaiņas uzturā (no augsta tauku satura un zema šķiedrvielu satura uztura pārejot uz zema tauku un augsta šķiedrvielu satura uzturu) mazina cirkulējošo androgēnu līmeni, SHBG, nedaudz arī estradiola līmeni, kas, iespējams, ietekmē arī androgēnu metabolismu priekšdziedzera audos [Wang, 2005].

Tauki uzturā ar̄i mazina lignānu ekskrēciju ar urīnu, arī tad, ja ir identisks graudaugu šksiedrvielu daudzums uzturā. Tātad - ENL mazina PV risku, bet tauki netieši to paaugstina, mazinot ENL producēšanu [Adlercreutz, 2010].

Ir pētìta arī tauku/šksiedrvielu attiecības ietekme uz dzimumhormonu līmeni. Dati rāda, ka diēta ar augstu tauku saturu un mazu šksiedrvielu daudzumu palielina

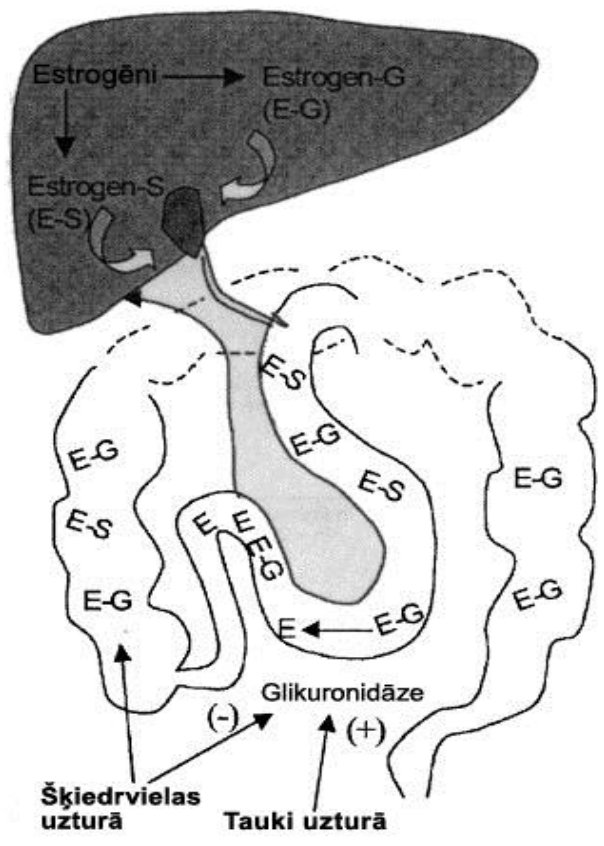

1.11. att. Tauku un šķiedrvielu ietekme uz enterohepatisko cirkulāciju, ietekmējot enzīmu aktivitāti. G - glikuronīdi; S - sulfāti [Horner, 2000] estrogēnu līmeni, un, iespējams, taukiem uz estrogēnu metabolismu ir lielāka ietekme nekā Šķiedrvielām [Aubertin-Leheudre, 2008a]. Biliārie estrogēni ir konjugēti, un pirms absorbēšanās tiem jātiek hidrolizētiem. Palielināta $\beta$ glikuronidāzes aktivitāte fēcēs ir saistita ar uzturu, kas satur daudz tauku un maz šķiedrvielu, un tā sekas ir palielināta estrogēnu reabsorbcija [Aubertin-Leheudre, 2008a] (1.11. att.). 
Tiek pētīta arī lipīdu profila asin̄̄s saistība ar PV attīstību un progresēšanas straujumu. In vitro pêtījumi rāda, ka PV šūnas tiešā veidā izmanto lipīdus kā enerǵijas avotu audzēja proliferācijai un migrācijai [Noel, 2009], un ir ziņojumi, ka lipīdu līmeni pazeminošo medikamentu (statīnu) lietošana ievērojami mazina PV pacientu mirstību [Platz, 2006] un, iespējams, mazina arī PV risku [Murtola, 2010].

\subsubsection{Sakṇaugi un citi dārzeṇi uzturā}

Plaši pētījumi veikti arī par sakņaugu un citu dārzeņu lomu PV riska mazināšanā. Biežāk pētītie mehānismi ir antioksidatīvā protekcija, aizsargājot dezoksiribonukleīnskābi (DNS) un šūnas no bojājumiem [World Cancer Research Fund/ American Institute for Cancer Research, 2007]. Saistībā ar sakņaugu un citu dārzeņu lietošanu visvairāk kā protektīvie uztura faktori ir pētīti tomāti, krustziežu dzimtas (vai kāpostu dzimta - Brassicaceae) dārzeņi, sīpolu dzimtas (Alliaceae) augi, pākšaugi, $\beta$ karotīni, C un E vitamīni [Chan, 2009].

Tomāti un tomātu ēdieni (dažādas tomātu mērces, konservēti tomāti, tomātu zupas) satur daudz augu aktīvo vielu, kas varētu būt iesaistītas kanceroǵenēzes kavēšanā, tomēr visvairāk pētīts ir likopēns. Likopēns ir spēcīgs antioksidants, karotinoīds, ko var noteikt plazmā, daudzos audos, tostarp priekšdziedzera audos. Likopēna nozīmīgākāa protektīvā darbība ir pasargāšana no priekšdziedzera audu oksidatīva DNS bojājuma. In vitro pētījumi rāda, ka likopēns kavē PV šūnu augšanu [Khan, 2010]. Epidemioloǵiskie pētījumi norāda, ka tomāti varētu mazināt PV risku. Norādījumi par tomātu lietošanas aizsargājošo ietekmi pārsvarā tika konstatēti kohortu pētījumos, mazāk - gadījuma kontroles pêtîjumos [Kim, 2003; Chan, 2009]. Novērtēt likopēna daudzumu uzturā ir sarežḡīti, jo likopēns nav ietverts daudzās pārtikas produktu datubāzēs un tā koncentrācijas variē, piemēram, dažādu ražotāju tomātu mērcēs. Tāpēc uzskata, ka labāks rādītājs varētu būt likopēna koncentrācija asin̄̄s. Augstāka likopēna koncentrācija asin̄̄s var pasargāt no izplatīta PV attīstības [Key, 2007; Chan, 2009]. Kopumā lielākā daļa pētījumu norāda, ka tomāti uzturā un augstāks likopēna līmenis serumā, iespējams, darbojas protektīvi, mazinot PV risku [Schmid, 2011; Wei, 2012].

Krustziežu dzimtas augi (galviņkāposti, ziedkāposti, Briseles kāposti, brokoḷi, rāceņi, kāḷi) satur daudz glikozinolātu, kas degradējas par biolog̣iski aktīviem 
izotiocianātiem un indoliem. Antikancerogēnā iedarb̄̄ba izpaužas, veicinot detoksificējošo enzīmu (glutationa-S-transferāzes (GST) un NADPH-hinona oksidoreduktāzes) darbību, kuriem ir nozīme kancerogēnu metabolismā [Leitzmann, 2012]. Ir pētītas tādas krustziežu dzimtas augu fitoķīmisko vielu antikancerogēnās īpašības kā šūnu cikla bloķēšana, pretiekaisuma aktivitāte, audzēja invāzijas un angioǵenēzes kavēšana [Higdon, 2007]. Daudzo klīnisko pētījumu rezultāti rāda krustziežu dzimtas augu protektīvo ietekmi - zemāku agresīva PV risku [Kirsh, 2007]. Ir norādījumi, ka krustziežu dzimtas augiem ir protektīva loma, ietekmējot agrīnos priekšdziedzera kanceroǵenēzes procesus jaunākiem vīriešiem, kas šos dārzeņus lielākā daudzumā lieto jau ilgstoši (>10 gadus), bet nav ietekmes uz klīniski izplatīta PV progresēšanu, kad kanceroǵenēzes process, iespējams, jau sācies pirms gadu desmitiem [Giovannucci, 2003]. Pētīta arī glikozinolātu daudzuma uzturā negatīvā saistība ar PV risku [Leitzmann, 2012], tomēr rezultāti ir pretrunīgi [Chan, 2005; World Cancer Research Fund/ American Institute for Cancer Research, 2007; Bosetti, 2012].

Sīpolu dzimtas augi (ķiploki, sīpoli, loki, puravi, lakši) satur daudz flavonoīdu un organiskā sēra savienojumu. Visvairāk pētìta ir iespējamā ķiploku iedarbība. Ķiploki satur sēra savienojumu S-alilcisteīnu. Iespējamie protektīvie mehānismi ir vēža šūnu apoptozes izraisīšana, kancerogēnu detoksificēšana, šūnu cikla bloķēšana, PSA līmeņa mazināšana [Zheng, 2007]. Lai gan pētîjumi in vitro un in vivo norāda uz sīpolu dzimtas augu protektīvo iedarbību, tomēr populāciju pētījumu dati ir pretrunīgi [Chan, 2009].

\subsubsection{Tēja un kafija}

Atsevišşi pētījumi norādījuši uz kafijas saistību ar palielinātu risku [Leitzmann, 2012], tomēr pēdējo gadu pētījumi rāda negatīvu saistību starp PV risku un kafijas lietošanu, īpaši attiecībā uz izplatītu PV [Wilson, 2011]. Autori izsaka hipotēzi, ka iespējamā antikancerogēnā aktivitāte ir saistīta ar antioksidatīvo un pretiekaisuma darbību, kā arī ar insulīna sensitivitātes uzlabošanos, un protektīvie komponenti kafijā ir lignāni un hlorogēnskābe [Wilson,2011].

Tējas iespējamā iedarbība vairāk pētîta vīriešiem Āzijas regiionā, kas tēju lieto daudz vairāk nekā vīrieši Eiropā. Metaanalīzē konstatēts, ka zaḷās tējas lietošanai, iespējams, ir protektīva ietekme, kavējot PV attīstību, par melnās tējas lietošanu šādu datu nav [Zheng, 2011]. 


\subsubsection{Piena produkti un kalcijs}

Daudzi, bet ne visi pētījumi, rāda piena produktu lietošanas pozitīvo saistību ar PV risku. Metaanalīzē (ietverti pētîjumi līdz 2006. gadam) tika konstatēta pozitīva saistība starp piena produktu lietošanu un PV risku [Qin, 200]. EPIC (multicentru prospektīvs pētījums, kas ietver 23 centrus no 10000 valstīm, 153457 vīriešus) rezultāti rāda, ka piena produktu olbaltumvielu daudzums uzturā, kā arī kalcijs no piena produktiem uzturā saistīts ar PV risku [Gonzalez, 2010]. Iespējamā kancerogēnā iedarbība tiek skaidrota ar kalciju, piesātinātiem taukiem un hormoniem, ko satur piena produkti. Kalcija uzn̦emšana savukārt korelē ar IGF-1, kā arī 1,25 hidroksivitamīna $\mathrm{D}_{3}$ $\left(1,25(\mathrm{OH})_{2} \mathrm{D}_{3}\right)$ veidošanās nomākšanu. Metaanalīzēs konstatēts, ka vīriešiem, kas uzņem vairāk kalcija, pieaug PV risks [Gao, 2005; Lampe, 2011]. Tomēr citi pêtījumi neuzrāda šādu saistību [Park, 2007]. Nesenā lielā prospektīvā pētījumā konstatēts, ka piena produktu lietošana (izņemot pilnpienu) pēc PV diagnozes noteikšanas nepalielina letāla PV risku [Pettersson, 2012]. Pozitīva kalcija saistība ar izplatītu PV pārsvarā ir konstatēta gadījumos, kad uzṇemtas l̦oti lielas kalcija devas ( $\geq 2000 \mathrm{mg} / \mathrm{d})$, ko var veikt, tikai lietojot uztura bagātinātājus. Tāpēc, lietojot kalcija preparātus, tomēr jāṇem vērā iespējamais PV risks [Leitzmann, 2012].

\subsection{Aptaukošanās un priekšdziedzera vēzis}

Aptaukošanās saistīta ar dažādas lokalizācijas vēžu paaugstinātu incidenci un mirstību. Aptaukošanās ir arī PV iespējamais riska faktors, kas lielā mērā saistīts ar uzņemto uzturu. Pasaules Veselības organizācija (PVO) definē aptaukošanos, ja ķermeņa masas indekss (ĶMI) ir lielāks par $30 \mathrm{~kg} / \mathrm{m}^{2}$. Aptaukošanās negatīvi ietekmē priekšdziedzera veselību, palielinot gan labdabīgas priekšdziedzera hiperplāzijas (LPH), gan PV risku [MacInnis, 2006; Rodriguez, 2007; Tewari, 2012]. Ir zināms, ka aptaukošanās un ar to saistītā insulīna līmeņa paaugstināšanās saistīta ar PV agresīvāku norisi un nelabvēlīgāku rezultātu [Su, 2011; Grossmann, 2012], un daļa pētījumu rāda, ka mazinās mazagresīva PV risks [Buschemeyer, 2007]. Aprakstīti vairāki iespējamie darbības mehānismi. Ir zināms, ka taukaudi ir bioloǵiski aktīvi audi, kas, izdalot autokrīnus un parakrīnus faktorus, ietekmē citokīnu un hormonu profilu [Grossmann, 2012; Tewari, 2012]. Piemēram, tādi citokīni kā audzēja nekrozes faktors $\alpha$ (TNF- $\alpha$ ) un interleikīns 6 (IL-6), ko izdala taukaudi, bieži ir paaugstināti PV pacientiem, un tiem, 
iespējams, ir nozīme slimības progresēšanā [Giri, 2001], augstāks leptīna līmenis saistīts ar lielāku PV tilpumu un agresivitāti [Hoda, 2012]. Metabolie faktori un androgēni sekmē kanceroǵenēzi ar daudzu mehānismu palīdzību - nozīme ir iekaisuma reakcijai organismā, adipokīnu darbībai, taukskābju metabolismam un insulīnam līdzīgajam augšanas faktoram [Grossmann, 2012].

Kaut gan adipozitāte saistîta arī lielāku priekšdziedzera tilpumu, tā paradoksāli saistīta ar zemāku PSA līmeni [Rodriguez, 2006; Beebe-Dimmer, 2008]. To skaidro ar palielinātu plazmas tilpumu vīriešiem ar adipozitāti [Grubb,2009]. Adipoziem vīriešiem pieaug risks novēlotai PV diagnostikai, jo ir gan zemāks PSA līmenis, gan palielināts priekšdziedzera tilpums, un, veicot priekšdziedzera biopsijas, pastāv lielāka iespēja nekonstatēt mazus lokālus audzējus. Būtiskākā taukaudu un aptaukošanās iespējamā ietekme uz priekšdziedzera audiem [Tewari, 2012]:

1) zemāks PSA, kas apgrūtina diagnostiku;

2) audzējs var palikt neidentificēts, jo ir lielāks priekšdziedzera tilpums;

3) apgrūtināta ķirurğiskā pieeja, audzējs var palikt neekstirpēts;

4) perifēra androgēnu aromatizācija;

5) insulīna rezistence;

6) angioǵenēze;

7) pārmainīta adipokīnu un augšanas faktoru sekrēcija;

8) pārmainīta triglicerīdu un taukskābju koncentrācija;

9) hronisks iekaisuma process;

10) bioloğiski agresīvāka slimība.

Citas ar aptaukošanos saistītās hormonālās izmaiņas, kā samazināts testosterona līmenis un paaugstināts estrogēnu līmenis, varētu mazināt PV risku.

Tātad var secināt, ka aptaukošanās ir vāji saistīta ar kopējo PV risku. ĶMI ir saistīts ar izplatīta PV risku, bet nav saistīts ar lokalizēta PV klīniskās formas risku [Leitzmann, 2012].

Vīriešiem ar 2. tipa cukura diabētu ir raksturīga hiperinsulinēmija, kas varētu paaugstināt PV risku, veicinot audzēja šūnu augšanu. Tomēr epidemioloǵiskie pētījumi rāda pretējo - negatīvu saistību starp cukura diabētu un PV risku [Kasper,2006; Müller, 2009]. Vīriešiem ar aptaukošanos un cukura diabētu ir mēreni samazināts androgēnu līmenis, un ir dati, ka cukura diabēts, ar kuru slimo ilgāku laiku, kaukāziešu jeb eiropeīdu rases pārstāvjiem saistīts ar zemāku PV risku, to apstiprina gan kohortu pētījumi, gan metaanalīzes [Waters, 2009; Grossmann, 2012; Onitilo, 2012; Tewari, 
2012]. Atsevišķu pētījumu dati rāda, ka pēc CD diagnozes noteikšanas palielinās PV risks, bet tas mazinās vēlākos gados pēc diagnozes noteikšanas, kas, iespējams, saistîts ar sākotnēju hiperinsulinēmiju un normoinsulinēmiju vai hipoinsulinēmiju vēlākos gados [Tewari, 2012]. Iespējams, nozīme ir arī zemākam androgēnu līmenim [Grossmann, 2011]. Ir arī norādījumi, ka, kaut arī ir negatīva saistība starp CD un PV agrīnās stadijās, tomēr cukura diabēts saistīts ar slimības agresīvu norisi [Leitzmann, 2008].

Cits iespējamais mehānisms - aptaukošanās - ietekmē arī lignānu metabolismu. Konstatēts, ka aptaukošanās ir negatīvi saistīta ar ENL līmeni sievietēm [Kilkkinen, 2001]. Tā kā ENL, iespējams, ir protektīva ietekme, tad zemāks ENL līmenis biologiiskajos šķidrumos var būt saistīts ar augstāku PV risku.

\subsection{D vitamīns}

D vitamīna metabolisms. Pierādījumi liecina, ka D vitamīnam piemīt antikancerogēna iedarbība. Cilvēki saņem D vitamīnu saules ekspozīcijas rezultātā caur ādu, ar uzturu un D vitamīna preparātu veidā (medikamenti vai uztura bagātinātāji). 90\% D vitamīna veidojas saules gaismas iedarbībā [Schwartz, 2009]. D vitamīns, kas tiek uzṇemts ar uzturu un veidojas ādā saules ultravioletā starojuma B (UV-B, viḷna garums 280-315 nm) iedarbībā, ir biologiiski inerts. Tas vispirms tiek hidroksilēts aknās, kur veidojas 25-hidroksivitamīns D (25(OH)D), pēc tam nieru (un arī citi audi, ieskaitot priekšdziedzera audi) pārveido $25(\mathrm{OH}) \mathrm{D}$ par biologiski aktīvu vitamīnu, kalcitriolu: 1,25-dihidroksivitamīnu $\mathrm{D}_{3}\left(1,25(\mathrm{OH})_{2} \mathrm{D}_{3}\right)$. Renālo $\mathrm{D}$ vitamīna metabolismu regulē parathormons $(\mathrm{PTH})$ un seruma kalcija un fosfora līmenis. Kalcija renālā un intestinālā kalcija un fosfora absorbcija palielinās, palielinoties $1,25(\mathrm{OH})_{2} \mathrm{D}_{3}$ koncentrācijai. D vitamīna fiziologija atspoguḷota 1.12. attēlā.

Lai gan $1,25(\mathrm{OH})_{2} \mathrm{D}_{3}$ ir $\mathrm{D}$ vitamīna aktīvā forma, D vitamīna krājumus organismā vislabāk ataino 25(OH)D un tā noteikšanu lieto, lai izvērtētu D vitamīna līmeni organismā, jo tā ir dominējošā D vitamīna forma asinīs un tai ir ilgāks eliminācijas pusperiods nekā 1,25(OH) ${ }_{2} \mathrm{D}_{3}$ (15 dienas versus 15 stundas) [Holick, 2007; Donkena, 2011]. 


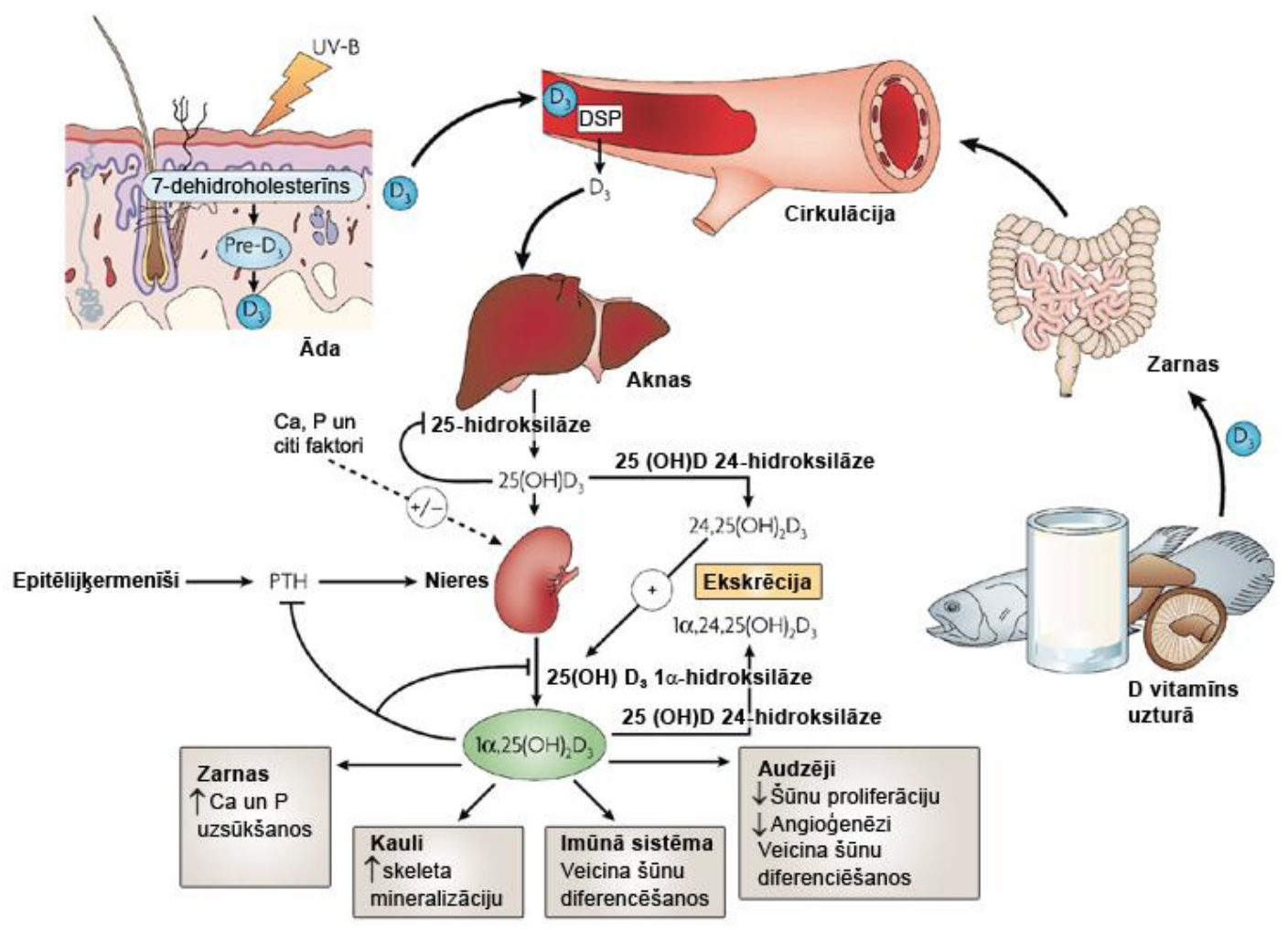

1.12. att. D vitamīna fizioloğija [Deeb, 2007]

DSP - D vitamīnu saistošais proteīns; UV-B - ultravioletais starojums B; PTH - parathormons

D vitamīna līmenis plazmā. Par optimālu 25(OH)D koncentrāciju nav panākts konsensus, tomēr visbiežāk pētījumos [Holich, 2007], kā arī ASV Endokrinologu asociācijas 2011. gada vadlīnijās (Endocrine Society clinical practical guideline [Holick, 2011]), Latvijas Osteoporozes un kaulu metabolo slimību asociācijas izdotajās Osteoporozes klīniskajās vadlīnijās [Latvijas Osteoporozes un kaulu metabolo slimību asociācija, 2011] un nesen publicētajās vadlīnijās Centrālās Eiropas iedzīvotāju D vitamīna deficīta ārstēšanai [Płudowski, 2013] tiek izmantoti šādi 25(OH)D seruma rādīiāji:

$25(\mathrm{OH}) \mathrm{D} \leq 20 \mathrm{ng} / \mathrm{mL}-\mathrm{D}$ vitamīna deficīts;

25(OH)D - 21-29 ng/mL - D vitamīna nepietiekamība;

25(OH)D - 30-50 ng/mL - optimāls D vitamīna līmenis.

Ņemot vērā šo definīciju, tiek vērtēts, ka ASV, Kanādā un Eiropā 20-100\% vecāka gadagājuma cilvēku ir D vitamīna deficīts vai nepietiekamība [Holick, 2011]. EPIC pētîjumā Eiropas valstīs PV pacientiem un kontroles grupā 39\% [Travis, 2009b], savukārt somu populācijā 50\% bija D vitamīna deficīts [Faupel-Badger, 2007]. 
Ieteicamā 25(OH)D koncentrācijai asin̄̄s - vismaz $30 \mathrm{ng} / \mathrm{ml}$ - nodrošina, lai neveidotos signāls papildu PTH sintēzei un nenotiktu kalcija mobilizācija no kauliem, kā arī lai D vitamīnam būtu arī cita protektīvā iedarbība, ne tikai uz skeleta un muskulu sistēmu [Holick, 2011]. Ir pētījums, ka Latvijā sievietēm vēlamais D vitamīna līmenis plazmā, kas pasargā no PTH palielināšanās, ir vismaz 38 ng/ml [Lejnieks, 2013]. Par vīriešiem Latvijā šādu datu nav.

\section{D vitamīna iedarbība uz priekšdziedzera vēža attīstības procesiem}

D vitamīna iedarbība uz priekšdziedzera vēža šūnām. Pašlaik uzskata, ka D vitamīns ietekmē gan PV etioloǵiju, gan progresēšanu divos veidos. Viens cirkulējošo D vitamīna metabolītu $\left(25(\mathrm{OH}) \mathrm{D}\right.$ un $\left.1,25(\mathrm{OH})_{2} \mathrm{D}_{3}\right)$ iedarbība, otrs - lokālā iedarbība priekšdziedzera audos [Gilbert, 2011]. D vitamīna sekmīgai bioloǵiskajai aktivitātei nepieciešami D vitamīna receptori. Šie steroīdu nukleārie receptori vairāk ir lokalizēti priekšdziedzera perifērajos rajonos (lokalizācija, kur pārsvarā veidojas priekšdziedzera vēzis) nekā centrālajā priekšdziedzera zonā [Schwartz, 2009].

Kā jau minēts, arī priekšdziedzeris piedalās D vitamīna aktīvās formas veidošanā. Gan veselā priekšdziedzerī, gan PV šūnās izdalās enzīms 25-hidroksivitamīna $\mathrm{D}_{3}$ 1- $\alpha$ hidroksilāze $\left(\mathrm{CYP}_{27} \mathrm{~B}_{1}\right)$, kas pārveido $25(\mathrm{OH}) \mathrm{D}$ par $1,25(\mathrm{OH})_{2} \mathrm{D}_{3}$. Ir pētījumi, kas rāda, ka PV šūnās 1- $\alpha$ hidroksilāzes ekspresija ir samazināta un tāpēc nesintezējas $1,25(\mathrm{OH})_{2} \mathrm{D}_{3}$ [Whitlatch, 2002]. Ir ziņojumi, ka tieši $25(\mathrm{OH}) \mathrm{D}$, nevis $1,25(\mathrm{OH})_{2} \mathrm{D}_{3}$ paaugstina 1- $\alpha$ hidroksilāzes aktivitāti priekšdziedzera vēža šūnās, tāpēc tiek ieteikts kā priekšdziedzera pretvēža vielu lietot $25(\mathrm{OH}) \mathrm{D}$, nevis $1,25(\mathrm{OH})_{2} \mathrm{D}_{3}$, kas draud ar hiperkalcēmiju [Lou, 2004a]. Savukārt citi pētnieki uzskata, ka PV šūnas ir zaudējušas spēju sintezēt 1- $\alpha$ hidroksilāzi, bet saglabājušas D vitamīna receptorus, tāpēc terapijā indicēts $1,25(\mathrm{OH})_{2} \mathrm{D}_{3}$ [Schwartz, 2009].

Pretēji 1- $\alpha$ hidroksilāzei enzīms 25-hidroksivitamīna D 24-hidroksilāze $\left(\mathrm{CYP}_{24} \mathrm{~A}_{1}\right)$ ir katabolisks enzīms, kas inaktivē $1,25(\mathrm{OH})_{2} \mathrm{D}_{3}$ un, iespējams, kavē antiproliferatīvos procesus. Ir pētīts, ka genisteīns, sojas izoflavons, palielina $1,25(\mathrm{OH})_{2} \mathrm{D}_{3}$ antiproliferatīvo efektu, mazinot 24-hidroksilāzes aktivitāti [Swami, 2005].

Domājams, ka D vitamīna pretvēža aktivitāte izpaužas, iedarbojoties uz nukleāriem D vitamīna receptoriem, kavējot PV šūnu funkcijas izmaiņas, ieskaitot vēža šūnu proliferācijas kavēšanu, šūnu cikla attīstību, šūnu invāziju, angioǵenēzi, var izraisīt šūnu diferenciāciju un apoptozi [Karlsson, 2010]. 
Hronisks iekaisuma process ir atzīts par riska faktoru daudzu vēža veidu, tostarp arī PV, attīstībā. Ar vēzi saistītam iekaisuma procesam raksturīgi, ka audzēja audos veidojas iekaisuma šūnas un paaugstinās tādu iekaisuma mediatoru kā citokīnu, hemokīnu, prostaglandīnu (PG) aktivitāte. Šie iekaisuma mediatori veicina ļaundabīgu transformāciju un vēža progresēšanu, kā arī angioǵenēzi, metastazēšanos un invāziju. Kalcitriols kavē iekaisuma prostaglandīnu (PG) sintēzi un biologisko iedarbību trijos veidos [Krishnan, 2010]:

1) nomāc ciklooksigenāzes-2 (COX-2 - enzīms, kas nodrošina PG sintēzi) ekspresiju;

2) pazemina PG receptoru ekspresiju;

3) paaugstina 15-hidroksiprostaglandīndehidrogenāzes (15-PGDH) (enzīma, kas inaktivē PG) ekspresiju.

Kalcitriols, iespējams, kavē PV progresēšanu, kā arī paaugstina jutību pret staru terapiju. D vitamīna molekulāro pretiekaisuma darbības mehānismu kopsavilkums ietver (1.13. att.) [Krishnan, 2010]:

1) PG sintēzes un bioloǵiskās darbības nomākšanu;

2) veicina mitogēnu aktivētās proteīnkināzes-fosfatāzes-5 (MKP-5) ekspresiju ar stresa kināzes aktivāciju, kas savukārt kavē iekaisuma citokīnus (ieskaitot interleikīnu-6 (IL-6));

3) iedarbojas uz nukleāro faktoru- $\kappa \mathrm{B}(\mathrm{NF \kappa B})$, kā rezultātā mazinās tādu iekaisuma citokīnu kā interleikīna-8 (IL-8) sintēze;

4) paaugstina insulīnam līdzīgā augšanas faktora saistošo proteīnu-3 (IGFBP3) ekspresiju, kas aptur proliferāciju un kavē NFкB aktivāciju;

5) nomācoša iedarbība uz tādiem angioǵenēzi stimulējošiem faktoriem kā hipoksiju veicinošais faktors-1 (HIF-1), asinsvadu endotēlija augšanas faktors (VEGF), IL-8;

6) regulē tādus molekulāros mediatorus kā proteolītisko enzīmu matrices metālproteināzi-9 (MMP-9) un audzēju nomācošo E kadherīnu, kā rezultātā tiek kavēta invāzija un metastazēšanās. 


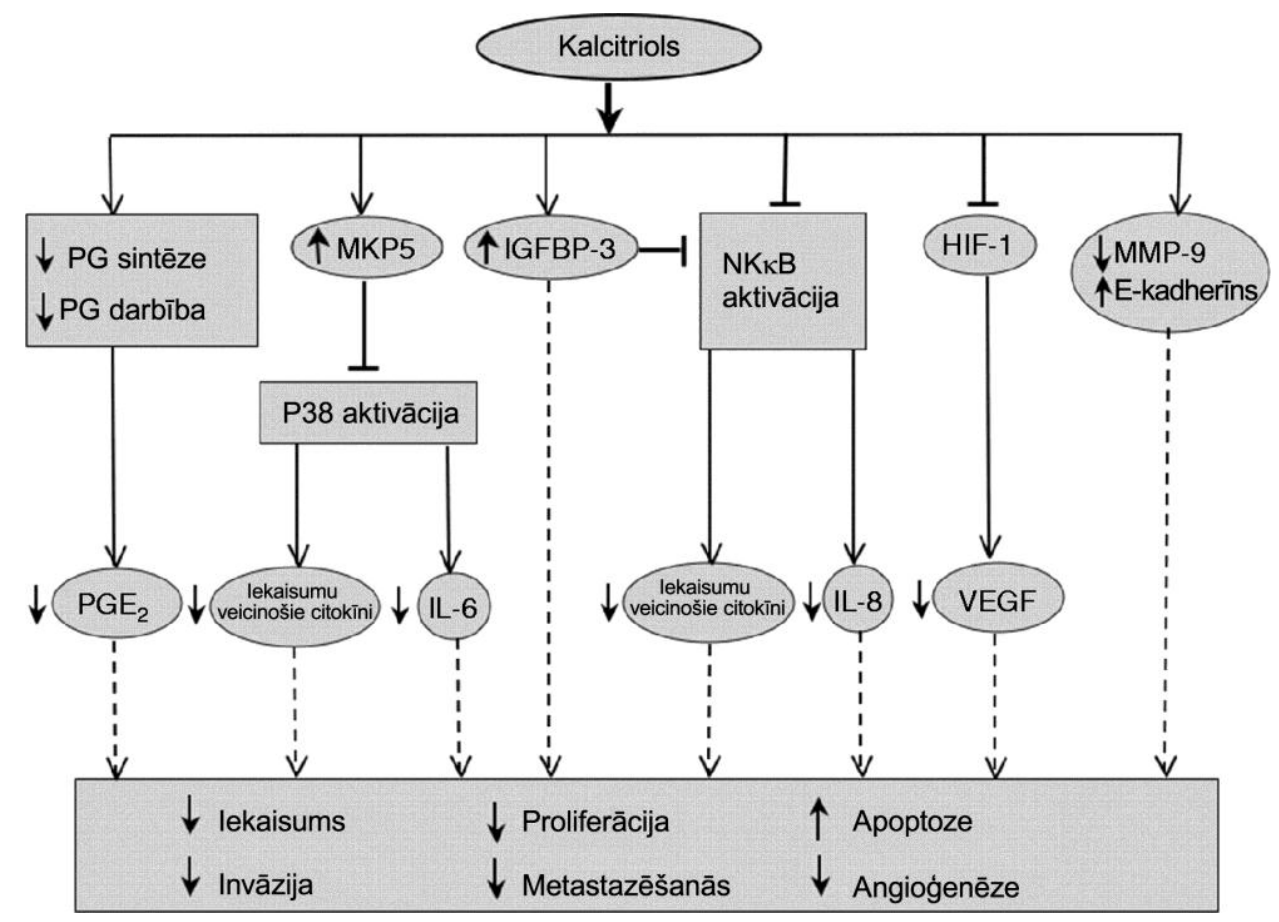

1.13. att. Kalcitriola pretiekaisuma darbības molekulārie darbības mehānismi [Krishnan, 2010]

PG - prostaglandīni; MKP-5 - mitogēnu aktivētā proteīnkināzes-fosfatāze-5; VEGF - asinsvadu endotēlija augšanas faktors; IL-6 - interleikīns 6; IGFBP-3 - insulīnam līdzīgā augšanas faktora saistošais proteīns-3 ; NFאB - nukleārais faktors $\kappa B$; IL-8 - interleikīns 8;

HIF-1 - hipoksiju inducējošais faktors-1; MMP-9 - matrices metālproteināze-9

Saules ekspozīcija un priekšdziedzera vēzis. Saules ekspozīcija ir galvenais D vitamīna avots. D vitamīns, kas izstrādājas ādā, asinīs atrodas vismaz divreiz ilgāk nekā ar uzturu uzņemtais D vitamīns. Kad pieaugušais peldkostīmā saņem vienu minimālo eritēmas devu (vieglu ādas apsārtumu 24 stundas pēc saules ekspozīcijas), tad producētais D vitamīna daudzums ir ekvivalents ar uzturu uzņemtām D vitamīna 10 000-25 000 SV. Vitamīna izstrādāšanos ādā mazina daudzi faktori, t.sk. ādas pigmentācija, vecums, saules aizsargkrēmi. Platuma grādos zem $33^{\circ}$, īpaši ziemā, D vitamīna sintēze ādā ir ļoti zema [Holick, 2011].

D vitamīna nepietiekamība un deficīts ir kḷuvis par sabiedrības veselības problēmu, jo aptver lielu populācijas daļu. Visvairāk šī problēma skar Ziemel̦eiropas valstis, Amerikas Savienotās Valstis, etniskās grupas ar tumšu ādas krāsu un tos cilvēkus, kam ir zema fiziskā aktivitāte un kas maz uzturas ārpus telpām. Par Latviju pašlaik ir dati par veselām sievietēm, kas dzīvo Rīgā (ǵeogrāfiskais platums $-57^{\circ}$ ), un, kā varētu prognozēt, sievietēm, kas nebija lietojušas D vitamīnu preparātu formā, D vitamīna līmenis statistiski ticami augstāks bija vasarā nekā ziemā, savukārt PTH 
līmenis negatīvi korelēja ar D vitamīna līmeni serumā. Jāuzsver, ka arī vasarā 59,8\% sieviešu D vitamīna līmenis serumā nesasniedza vēlamo līmeni [Lejnieks, 2013].

Zināms, ka saules ekspozīcija palielina D vitamīna sintēzi ādā, kas var mazināt vairāku lokalizāciju, tostarp priekšdziedzera vēža, risku. Vienlaikus palielināta UV-B ekspozīcija var izraisīt ādas vēzi. Ir daudz pētījumu, arī gadījumu kontroles un prospektīvi pētījumi, kas rāda, ka saules ekspozīcijas stiprums ir negatīvi saistīts ar PV risku [John, 2004; Van der Rhee, 2009]. Ģeogrāfiskos rajonos ar mazāku saules ekspozīciju novērota augstāka mirstība no PV [Schwartz, 2006]. Ir pētījumi, kas norāda, ka pacientiem, kuriem PV diagnosticēts vasarā, ir garāka dzīvildze nekā tiem, kuriem PV diagnosticēts ziemā [Lagunova, 2007]. Tiek izteikta hipotēze, ka melnādainajiem vīriešiem ir augstāks PV risks, jo ādas pigmentācijas dēl UV radiācija iedarbojas mazāk [Lagunova, 2003], tomēr konstatēts, ka melnādainajiem vīriešiem atšķirībā no baltādainajiem PV risks nav saistīts ar saules ekspozīciju [Collo, 2008]. Kaut arī daudzos pētījumos tiek norādīts, ka UV-B starojums mazina PV attīstības risku, kā arī progresēšanu, tomēr ir arī daļa pētījumu, kas neapstiprina šo hipotēzi [Waltz, 2008; Gilbert, 2009; ].

Cirkulējošais D vitamīns un priekšdziedzera vēža risks. Pētījumu rezultāti par cirkulējošā D vitamīna saistību ar PV risku ir pretrunīgi. Ir pētījumi, kas atbalsta D vitamīna protektīvo lomu [Holick, 2007; Donkena, 2011], un pētījumi, kuru rezultāti rāda D vitamīna seruma koncentrācijas negatīvu saistību ar PV risku, kā arī zema D vitamīna līmeņa saistību ar agresīvu PV [Ahonen, 2000; Gilbert, 2012] un augstāka D vitamīna līmeņa saistību ar lēnāku PV progresēšanu [Li, 2007; Tretli, 2009]. D vitamīna iespējamā PV kavējošā darbība tiek pētìta arī saistībā ar tā ietekmi uz PSA līmeni. Ir dati, kas rāda, ka PSA pieaugums PV pacientiem ir mazāks pavasara un vasaras mēnešos, kad ir augstāks D vitamīna līmenis [Vieth, 2006]. Nelielos intervences pētījumos ir norādījumi, ka D vitamīns pazemina PSA PV pacientiem [Woo, 2005].

Vienlaikus ir arī daudz pētījumu, kas parāda, ka nav negatīvas saistības starp cirkulējošo D vitamīnu un PV risku. Gan metaanalīzēs [Yin, 2009; Gandini, 2011], gan prospektīvā osteoporozes multicentru pētījumā par vecākiem vīriešiem [Barnett, 2010], kā arī lielā Eiropas gadījumu kontroles pētījumā EPIC (European Prospective Investigation into Cancer and Nutrition) [Travis, 2009b] secina, ka D vitamīna līmenim nav ietekmes uz PV risku. Konstatēta arī U veida saistība starp PV risku un 25(OH)D koncentrāciju, secinot, ka gan zema, gan augsta D vitamīna koncentrācija var būt saistīta ar PV risku. Zema D vitamīna koncentrācija pasliktina mitozes kontroles 
procesu, savukārt augsta var radīt D vitamīna rezistenci, pieaugot 24-hidroksilāzes aktivitātei, kas palielina D vitamīna inaktivācijas procesus [Tuohimaa, 2004].

Cēlonis tam, ka neizpaužas D vitamīna protektīvā darbība, var būt D vitamīna metabolisma pārmaiņas vai rezistence pret D vitamīnu. Rezistences cēloņi var būt paaugstināta D vitamīna katabolo enzīmu aktivitāte (1,25-D3-24-hidroksilāze), šo fermentu aktivitāte pieaug arī vecumā. Cits iespējamais D vitamīna rezistences cēlonis ir D vitamīna receptoru gēnu polimorfisms, kā arī endogēnie steroīdi un fitoestrogēni var modulēt D vitamīna metabolizējošo enzīmu izdalīšanos [Lou, 2004b].

Iespējams, ka seruma D vitamīna līmenis neatspoguḷo D vitamīna koncentrāciju lokālajos audos [Travis, 2009b]. Turklāt nav pietiekamas informācijas par D vitamīnu regulējošo enzīmu, kā arī D vitamīna metabolītu un $\mathrm{D}$ vitamīna receptoru aktivitāti normālos priekšdziedzera audos un PV audos in vivo apstākḷlos. Domājams, ka šos procesus lokālajos audos ietekmē ǵenētiski, epiğenētiski un citi endogēni un apkārtējās vides faktori, kas pašreizējā posmā vēl nav izpētīti [Donkena, 2011].

Intervences pētījumi ar D vitamīna preparātiem. PV lēni progresējoša norise sākotnējās slimības stadijās paver plašas pētījumu iespējas, izmantojot D vitamīna metabolītus. PV stadijas var sadalīt šādos posmos:

- vīrieši ar PV risku;

- priekšdziedzera intraepiteliāla neoplāzija;

- klīnisks PV;

- minimāla atlieku slimība.

Līdz šim lielākā daļa intervences pētījumu ir veikti pacientiem ar izplatītu, androgēnnejutīgu PV. Šādai klīniskai PV formai ir grūtāk sagaidīt pozitīvus rezultātus. Pētījumu rezultāti ir pretrun̄igi. Visbiežāk vēža augšanu nevar kavēt bez blakusiedarbības - hiperkalcēmijas. Te risinājums varētu būt mazākas kalcitriola devas vai kalcitriola analogu lietošana.

Ir daudz pacientu, kam konstatēts lokalizēts PV, kuriem terapijas taktika ir piesardzīga novērošana dinamikā (angl̦u val. watchful waiting). Šie vīrieši ar lēni progresējošu PV, kuriem tiek atlikta aktīva ārstēšana un kuri tiek novēroti, būtu piemēroti kandidāti D vitamīna metabolītu terapijai, kura, iespējams, kavētu PV attīstību.

Pašreizējā posmā ieteikumi primārajai prevencijai būtu - lietot 25(OH)D lielās devās, bet klīniski izplatīta vēža gadījumā $-1,25(\mathrm{OH})_{2} \mathrm{D}_{3}$. Šos D vitamīna metabolītus, 
iespējams, ir vēlams lietot kombinētā terapijā, piemēram, ar fitoestrogēniem [Schwartz, 2009].

D vitamīns uzturā un priekšdziedzera vēža attīstības risks. D vitamīnu satur tikai daži ikdienā lietojami uztura produkti (1.3. tab.).

1.3. tabula

D vitamīna avoti uzturā ( $D_{3}$ dz̄ivnieku valsts produktos, $D_{2}-$ sēnēs $)$ - Vācijas BLS, Maksa Rubnera institūta izveidotā pārtikas sastāva datu bāze

\begin{tabular}{|c|c|c|c|}
\hline Produkts & Daudzums & SV & $\mu \mathrm{g}$ \\
\hline Sil̦ķe, marinēta & $85 \mathrm{~g}$ & 680 & 17 \\
\hline Lasis, svaigs, mazsālīts & $85 \mathrm{~g}$ & 612 & 15,3 \\
\hline Lasis, konservēs ar asakām & $85 \mathrm{~g}$ & 520 & 13 \\
\hline Sardīnes & $85 \mathrm{~g}$ & 340 & 8,5 \\
\hline Tuncis, konservēts eḷıā & $85 \mathrm{~g}$ & 200 & 5 \\
\hline Mencas ikri & $85 \mathrm{~g}$ & 136 & 3,4 \\
\hline Siḷksu, laša ikri & $85 \mathrm{~g}$ & 68 & 1,7 \\
\hline Garneles, vārītas & $85 \mathrm{~g}$ & 34 & 0,85 \\
\hline Mencu aknu el̦̦a & $1 \mathrm{~g}$ & 118 & 2,95 \\
\hline Vistas aknas, pagatavotas & $85 \mathrm{~g}$ & 34 & 0,85 \\
\hline Liellopa aknas, pagatavotas & $85 \mathrm{~g}$ & 68 & 1,7 \\
\hline Vistas ola (dzeltenums) & $1 \mathrm{gab}$. & 40 & 1 \\
\hline Cūku tauki & $50 \mathrm{~g}$ & 12 & 0,3 \\
\hline Sviests & $10 \mathrm{~g}$ & 4 & 0,1 \\
\hline Piens $2,5 \%$ & glāze $250 \mathrm{ml}$ & 5 & 0,13 \\
\hline Kultivētās sēnes, svaigas & $100 \mathrm{~g}$ & 76 & 1,9 \\
\hline Baravikas, svaigas & $100 \mathrm{~g}$ & 124 & 3,1 \\
\hline Baravikas, žāvētas, saldētas & $100 \mathrm{~g}$ & 160 & 4 \\
\hline Baravikas, žāvētas & $100 \mathrm{~g}$ & 920 & 23 \\
\hline
\end{tabular}

ASV un Kanādā daudzi produkti tiek bagātināti ar D vitamīnu (piena, graudaugu produkti, apelsīnu sula). Eiropā pienu ar D vitamīnu bagātina tikai Zviedrijā un Somijā, bet daudzās valstīs D vitamīnu pievieno graudaugiem, margarīnam. Latvijā pieejami ar D vitamīnu bagātināti margarīni un daži jogurti.

Multivitamīni satur $400-1000 \mathrm{SV} \mathrm{D}_{2}$ vai $\mathrm{D}_{3}$ vitamīna.

Rekomendējamais D vitamīna daudzums uzturā [Holick, 2011]:

- 19-50 gadu vecumā vismaz 600 SV/d (starptautiskās vienības/dienā);

- 50-70 gadu vecumā - $600 \mathrm{SV} / \mathrm{d}$;

- $\geq 70$ gadu vecumā - vismaz $800 \mathrm{SV} / \mathrm{d}$.

Tomēr, lai 25(OH)D līmenis asin̄̄s pārsniegtu 30 ng/ml, ASV Endokrinologu asociācija iesaka $\geq 50$ gadu vecumā papildus lietot 1500-2000 SV/d [Holick, 2011]. 
Lai arī D vitamīnam uzturā ir mazāka loma optimāla D vitamīna līmeņa sasniegšanai serumā nekā saules ekspozīcijai, tomēr zināms, ka arī ar uzturu rekomendētās D vitamīna devas nesaņem liela daļa Eiropas populācijas. Vidējie D vitamīna rādītāji uzturā ir ievērojami zemāki par rekomendējamiem Austrijā, Vācijā, Lielbritānijā, Itālijāa Nīderlandē, Norvēgijāâ, İrijā [European Food Safety Authority, 2006]. Latvijas dati rāda, ka Latvijas iedzīvotāji vidēji uzṇem 68 SV D vitamīna, kas, iespējams, ir mazāk nekā reāli uzņemtais D vitamīna daudzums, jo arī citu uzturvielu un enerǵêtiskā vērtības rādītāji ir zemi [Nacionālais diagnostikas centrs, 2009]. Nesenā metaanalīzē noteikts, ka D vitamīna mediāna uzturā bija 112 SV [Gilbert, 2011].

Daudzi lieli pētījumu [Park, 2007; Kristal, 2012] un arī metaanalīzes [Huncharek, 2008a] norāda, ka nav saistības starp D vitamīna daudzumu uzturā un PV risku.

D vitamīns un fitoestrogēni. Kā zināms, $D$ vitamīna aktīvā forma $1,25(\mathrm{OH})_{2} \mathrm{D}_{3}$ (kalcitriols) veidojas ne tikai nierēs, bet arī citos audos. Arī priekšdziedzera audi spēj gan sintezēt $1,25(\mathrm{OH})_{2} \mathrm{D}_{3}$ no $25(\mathrm{OH}) \mathrm{D}$, gan noārdīt aktīvo D vitamīna formu. Citohroma C450 hidroksilāzes, kas nodrošina $1,25(\mathrm{OH})_{2} \mathrm{D}_{3}$ sintēzi (CYP27B1; 25-D3-1 $\alpha$-hidroksilāze) un katabolismu (CYP24; 1,25-D3-24-hidroksilāze), ir konstatējamas gan veselās, gan PV šūnās. Tiek izvirzīta hipotēze par $1,25(\mathrm{OH})_{2} \mathrm{D}_{3}$ iespējamu autokrīnu un parakrīnu protektīvu darbību audzēja šūnās, un CYP24 tiek uzskatīt par onkogēnu vielu, jo tas ātri katabolizē $1,25(\mathrm{OH})_{2} \mathrm{D}_{3}$ par mazāk aktīviem metabolītiem [Cross, 2004]. In vitro pētījumā soja un genisteīns palielina CYP27B1 un samazina CYP24 ekspresiju [Farhan, 2002] priekšdziedzera vēža šūnās, šî iedarbība varētu kavēt audzēja progresēšanu [Cross, 2004].

Citi pētījumi vērsti uz to, ka PV attīstību var kavēt, iedarbojoties uz PG metabolismu. Gan D vitamīnam, gan fitoestrogēniem ir antiproliferatīva aktivitāte. Tiek izteikta hipotēze, ka D vitamīna un fitoestrogēnu kombinēta lietošana var darboties protektīvi. Kalcitriols kavē PG metabolismu PV šūnās trīs veidos [Swami, 2007]:

1) mazina COX-2 koncentrāciju;

2) stimule 15-PGDH;

3) samazina $\mathrm{PGE}_{2}$ un $\mathrm{PGF}_{2 \alpha}$ receptoru aktivitāti.

Rezultātā mazinās biologiski aktīvā $\mathrm{PGE}_{2}$ koncentrācija, kas rada augšanas kavēšanu PV šūnās. Ir pētîta genisteīna (sojas fitoestrogēna) kombinācijas ar kalcitriolu iedarbība uz PV šūnām, kas būtu izmantojama gan PV prevencijā, gan ārstēšanā. Genisteīns kavē CYP24 aktivitāti, rezultātā paaugstinās kalcitriola biologiskāā aktivitāte. 
Turklāt genisteīns papildus CYP24 kavēšanai kavē arī COX-2, kā arī $\mathrm{PGE}_{2}$ un $\mathrm{PGF}_{2 \alpha}$ receptorus. Priekšrocības šāda veida kombinētai terapijai ir kalcitriola un genisteīna lietošanas relatîvais drošums, jo nesteroīdiem pretiekaisuma līdzekḷiem, kurus arī lieto, lai ietekmētu PG sistēmu, ir daudz blakṇu [Swami, 2007].

Par to, kā lignāni ietekmē D vitamīna metabolismu un biologiisko iedarbību, kā arī par sinerǵisku lignānu un D vitamīna iedarbību uz PV vēl nav veikti pētījumi. Var hipotētiski piel̦aut, ka iedarbība varētu būt līdzīga kā genisteīnam.

\subsection{Citi iespējamie priekšdziedzera vēzi ietekmējošie faktori}

Fiziskajai aktivitātei ir vāja negatīva saistība ar PV risku (metaanalīze 2011. gadā [Liu, 2011]). Iespējamie biolog̣iskie darbības mehānismi - ietekme uz specifiskiem augšanas faktoriem un hormoniem, tādiem kā insulīns, IGF-1 un D vitamīns.

Aspirīna un dažu nesteroīdo pretiekaisuma līdzekļu lietošana (propionāti, piemēram, ibuprofēns, naproksēns) var mazināt PV attīstības risku, jo kavē ciklooksigenāzes, nozīmīgākos enzīmus, kas nepieciešami prostaglandīnu sintēzei [Leitzmann, 2012].

Seksuālās uzvedības saistību ar PV risku var ietekmēt vairāki faktori. Seksuālās attiecības ar daudziem partneriem palielina seksuāli transmisīvo slimību risku, kā arī paaugstinās testosterona līmenis, kas var ietekmēt PV attīstības procesu. Metaanalīzē secināts, ka PV risks palielinās, pieaugot seksuālajai aktivitāte [Leitzmann, 2012]. Citi pētījumi rāda, ka ejakulācijas biežums ir negatīvi saistīts ar PV risku, ko varētu skaidrot ar toksīnu izvadīšanu no priekšdziedzera [Leitzmann, 2004b].

Par smēķēšanas saistību ar kopējo PV incidenci dati ir pretrunīgi. Atsevišķi pētījumi rāda, ka smēķētājiem ir mazāks lokalizēta PV risks, ko varētu skaidrot ar to, ka smēķētājiem PSA ir zemāks nekā nesmēķētājiem un, iespējams, smēķēetāji retāk veic PV skrīningu [Leitzmann, 2012]. Tomēr nesen veiktā metaanalīzē tiek secināts, ka smēķēěana tomēr ir saistîta gan ar PV incidenci, gan mirstību. PV risks ir statiski nozīmīgi lielāks tiem smēķētājiem, kas izsmēķēe lielu daudzumu cigarešu [Huncharek, 2010; Leitzmann, 2012].

Alkoholam nav pierādīta loma PV attīstībā [Huncharek, 2008b; Watters, 2010]).

Pētījumu par uztura bagātinātāju (multivitamīni, $\beta$ karotīni, retinols, tokoferols, selēns, C vitamīns) lietošanu rezultāti ir l̦oti heterogēni. Daḷā pētījumu konstatēja, ka nav ietekmes uz PV risku (E vitamīns ar selēnu; karotīni ar retinolu, C vitamīns, 
E vitamīns), daudzos konstatēja riska palielināšanos ( $\beta$ karotīns, vairāki pētîjumi ar multivitamīniem), vienā pētījumā vecākiem vīriešiem, smēķētājiem Somijā ( $\alpha$-tokoferols) konstatēja riska mazināšanos [Schmid, 2011; Leitzmann, 2012]. Jāsecina, ka kopumā uztura bagātinātājiem nav pierādīta protektīva loma PV riska mazināšanā.

\subsection{PSA skrīninga ieviešanas ietekme uz uztura pētījumu datu interpretāciju}

PSA skrīninga ieviešana pagājušā gadsimta deviņdesmitajos gados ievērojami mainīja PV incidenci. Pirms "PSA ēras" pārsvarā tika diagnosticēti izplatīti PV, bet pēc tam ievērojami biežāk tika diagnosticēta klīniski lokalizētas PV formas. Tātad pētījumos laikposmā pirms PSA ēras daudzi lokalizēti, asimptomātiski PV netika diagnosticēti. Viens pētījums tika izvērtēts divas reizes (pirms un pēc PSA skrīninga lietošanas), un tika iegūti atšksirīgi rezultāti par tomātu produktu un likopēna ietekmi uz PV risku [Giovannucci, 1995; 2002]. Tāpēc rezultāti un secinājumi par atsevišķu produktu vai uzturvielu ietekmi uz PV attīstību varēja atšķirties no pētījumiem, sākot no deviņdesmitajiem gadiem [Wei, 2012]. Minētie faktori palīdz izskaidrot, kāpēc uztura pētījumu rezultāti ir tik heterogēni. 


\section{MATERIĀLS UN METODES}

\subsection{Pētījuma dalībnieki un dizains}

Tika veikti divi pētījumi: gadījumu kontroles pêtījums un intervences pētījums. Abi pētijumi (gadījumu kontroles pētījums un intervences pētījums) saskaņoti P. Stradiņa KUS Attīstības fonda Zāḷ un farmaceitisko produktu klīniskās izpētes êtikas komitejā (ētikas komitejas atzinumi 1. pielikumā). Pētijumi reǵistrēti arī Rīgas Austrumu klīniskās universitātes slimnīcas (RAKUS) Zinātnes dạ̦ā. Katrs pētījuma dalībnieks sniedza rakstisku piekrišanu (pêtījumu dalībnieku piekrišanas veidlapas 2. pielikumā).

\subsubsection{Gadījumu kontroles pētījuma dizains}

Pētījumā tika ieklạta PV grupa un kontroles grupa. PV pacienti tika komplektēti Rīgas Austrumu KUS (RAKUS) Latvijas Onkolog̣ijas centra ambulatorajā dạ̧ā, kontroles grupas pacienti - Lailas Mikules un Irēnas Salgus gimenes ārstu praksē un uzṇēmumā „Rīgas satiksme”. Lielākā daļa no pētījuma dalībniekiem bija rīdzinieki. Pētījuma dalībnieki tika iekḷauti laika periodā no 2009. gada oktobra līdz 2012. gada februārim. Kopējā pētỉjuma shēma attēlota 2.1. attēlā. 


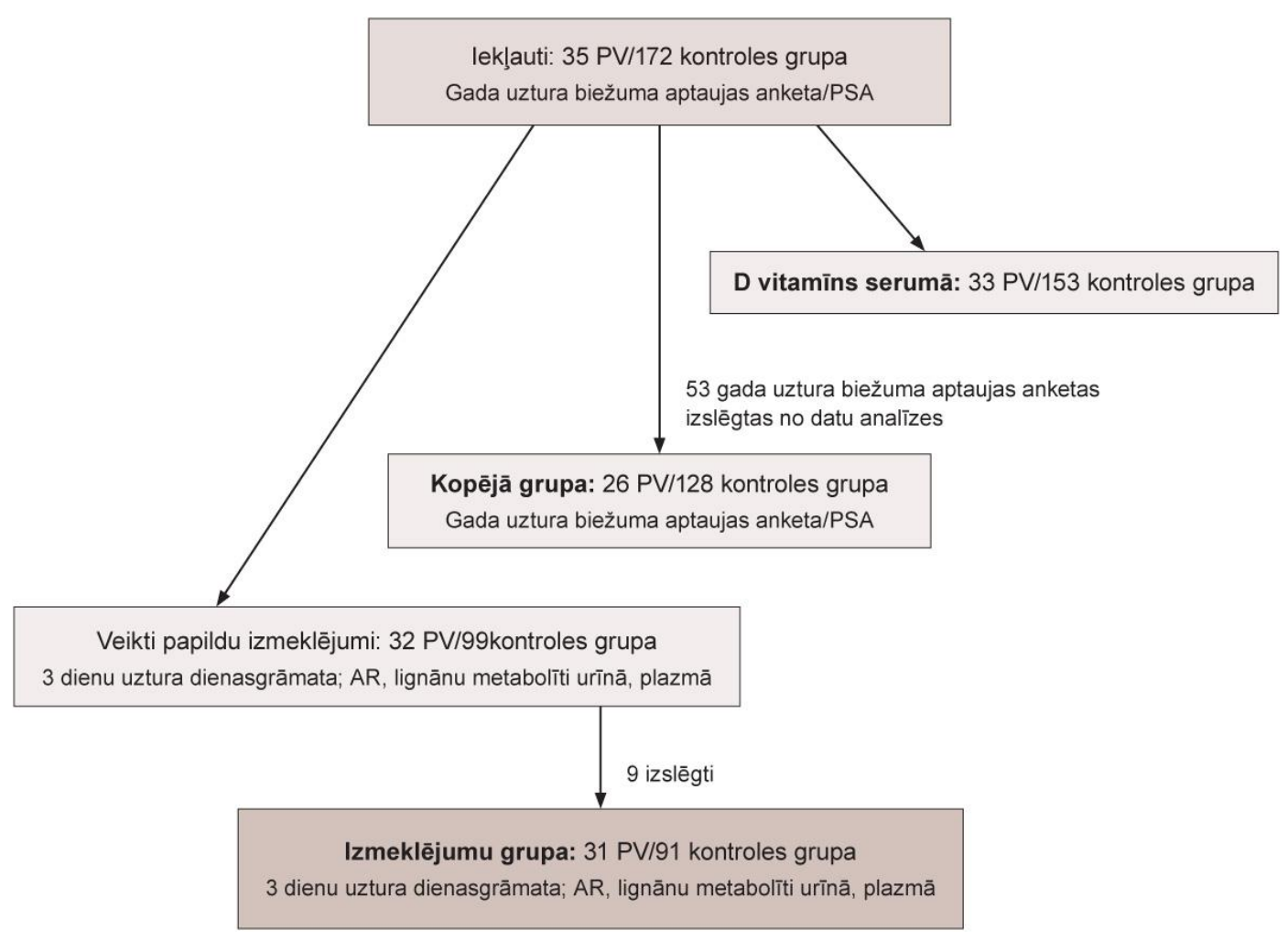

2.1. att. Gadījuma kontroles pētījuma kopējā shēma

Iekļaušanas kritēriji abām pētījuma grupām:

- $\quad$ vīrieši vecumā no 45 līdz 80 gadiem;

- dzīvo mājās, ēd parasto ikdienas uzturu.

Izslēgšanas kritēriji abām pētījuma grupām:

- $\quad$ PV anamnēze ǵimenē;

- hroniska nieru slimība;

- hroniska aknu slimība;

- 1. tipa cukura diabēts;

- $\quad$ citas lokalizācijas audzējs;

- pēdējo 5 gadu laikā mainījušies ēšanas paradumi;

- $\quad$ akūti apakšējo urīncel̦u simptomi;

- veǵetāra diēta.

Iekļaušanas kritēriji PV grupai:

- $\quad \mathrm{PV}$ - pirmo reizi diagnosticēts, diagnoze apstiprināta histoloğiski;

atbilst T1/T2/T3 N0 M0 klasifikācijai (TNM klasifikācija 3. pielikumā);

- $\quad$ PSA robežās no $2,5 \mu \mathrm{g} / \mathrm{L}$ līdz $20 \mu \mathrm{g} / \mathrm{L}$; 
- Glīsona (Gleason) skaitlis <8 (Glīsona metodika aprakstīta nodaḷā Morfologiskā izmeklēšana);

- nav sākta PV ārstēšana.

Ieklaušanas kritēriji kontroles grupai:

- $\quad$ digitāli rektālajā izmeklēšanā (DRI): nav datu par PV;

- transrektālajā ultrasonoskopijā (TRUS) - nav datu par PV;

- $\quad$ PSA līdz $20 \mu \mathrm{g} / \mathrm{L}$.

N̦emot vērā, ka risks saslimt ar PV ievērojami pieaug vecumā pēc 45 gadiem, izvēlēts atbilstošs pētījuma dalībnieku vecums. Otrs būtiskākais riska faktors ir ǵenētiskie faktori [American Cancer Society, 2012], tāpēc no pētījuma izslēgti pacienti ar PV gimenes anmnēzē, lai tas neietekmētu pētījuma rezultātus, izvērtējot uztura faktoru ietekmi uz PV risku. Tika analizēts pētījuma dalībnieku ierastais, pašu izvēlētais uzturs (netika iekḷauti dalībnieki, kuru uzturu nosaka kāda institūcija, piemēram, pansionātu iemītnieki). Veǵetārieši tika izslēgti, jo viṇu uzturs kardināli atšķiras no omnivoru uztura, tajā ir daudz vairāk fitoestrogēnu. Veǵgetārieši būtu jāpēta kā atsevišksa grupa, bet tie ir reti sastopami vecāku vīriešu vidū Latvijā. Tā kā PV attīstība visbiežāk notiek lēni - daudzu gadu vai gadu desmitu laikā, tika izslēgti dalībnieki, kas mainījuši ēšanas ieradumus pēdējo 5 gadu laikā. Netika iekḷauti dalībnieki, kam diagnosticēts citas lokalizācijas audzējs, hroniska aknu slimība, hroniska nieru slimība un 1. tipa cukura diabēts, jo šādiem pacientiem visbiežāk ir izmainīta vielmaiņa, uzturvielu biopieejamība. PSA, Glīsona skaiţ̦a un TMN klasifikācijas nosacījumi izvēlēti, lai pētītu pirmo reizi diagnosticēta PV pacientus, kam vēzis ir agrīnā stadijā, vēl nav izplatījies un tāpēc vēl neietekmēe ēšanas ieradumus (turklāt pacienti tika aptaujāti pirms diagnozes noteikšanas, tāpēc nevarēja būt mainījuši ēšanas ieradumus, uzzinot PV diagnozi), kā arī neietekmē vielmaiņu.

Sākotnēji pētījumā tika iekḷauti 35 pacienti PV grupā un 172 dalībnieki kontroles grupā.

Izmeklējumu apjoms ieklautajiem pētījuma dal̄̄bniekiem:

- gada uztura biežuma aptaujas anketa (5. pielikums);

- dzīvesveida anketa (4. pielikums);

- PSA;

- $25(\mathrm{OH}) \mathrm{D}$;

- urīna analīze; 
- urologa apskate, veicot DRI (digitāli rektālu izmeklēšanu);

- TRUS (transrektāla ultrasonoskopija) ar priekšdziedzera biopsiju:

○ $\quad$ PSA $>4,0 \mu \mathrm{g} / \mathrm{L}$;

○ $\quad$ PSA $\leq 4 \mu \mathrm{g} / \mathrm{L}$, bet nozīmē urologs pēc DRI.

Ja PSA $>4 \mu \mathrm{g} / \mathrm{L}$ vai vadoties pēc urologa indikācijām, pēc uztura datu ievākšanas un izmeklējumu veikšanas tika veikta TRUS ar priekšdziedzera biopsiju. Pēc biopsijas rezultātu iegūšanas pētījuma dalībnieks tika iedalīts PV vai kontroles grupā (2.2. attēls).

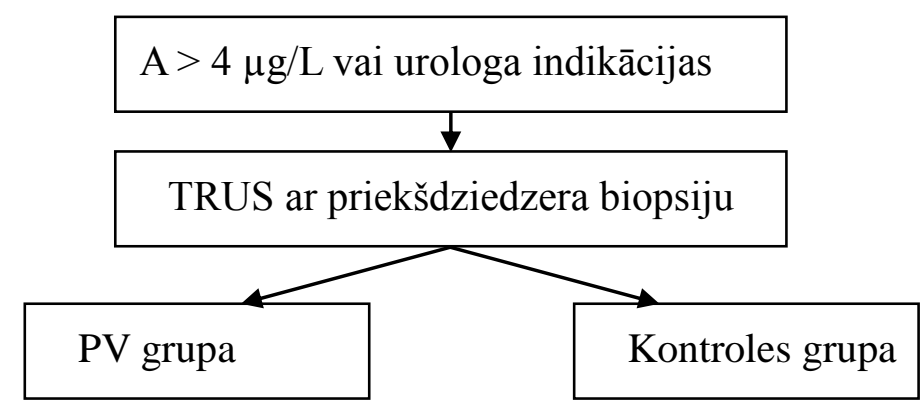

\section{2. att. Pētījuma shēma - iedalījums pētījuma grupās}

Dati par gimenes onkoloǵisko anamnēzi tika iegūti, aptaujājot pētījuma dalībniekus (sk. 4. pielikumu „Dzīvesveida anketa”). Aptauju veica Laila Meija un pētījumam apmācīta uztura speciāliste Daina Erdmane. Informācija par blakusslimībām tika iegūta no ǵimenes ārsta vai veicot pacienta aptauju, ņemot vērā viņa sniegto informāciju. PV diagnozi un TNM stadiju noteica urologs un patologs, ņemot vērā DRI, laboratoriskās izmeklēšanas, TRUS ar priekšdziedzera biopsiju rezultātus. Pētījumā piedalījās urologi Vilnis Lietuvietis, Māris Jakubovskis, Arkādijs Menis, Ivars Kukulis, Sergejs Beketovs, Samuels Gordins un patologs Māris Sperga.

Turpmākā datu analīzē tika izdalītas trīs grupas: Kopējā grupa, Izmeklējuma grupa un grupa, kam izmeklēts D vitamīns serumā.

1) Kopējā grupa: grupa ar datu analīzei atbilstošām gada uztura biežuma aptaujas anketām.

Iekḷautais pētîjuma dalībnieku skaits Kopèjā grupā: 26 pacienti PV grupā un 128 dalībnieki kontroles grupā.

Veicot datu statistisko apstrādi, saskaņā ar Willet metodiku [Willet, 2013] no turpmākās uztura datu analīzes tika izslēgtas tās gada uztura biežuma aptaujas anketas $(\mathrm{n}=53)$, kuru datos bija vecumam, ķermeņa masai, augumam un fiziskās aktivitātes 
pakāpei neatbilstoši augsts vai zems uzņemtās enerǵijas daudzums $(<700 \mathrm{kcal} / \mathrm{d}$ un $>4000 \mathrm{kcal} / \mathrm{d}$ ). Tâpēc rezultātā Kopējā grupā tika analizēti 26 pacienti PV grupā un 128 dalībnieki kontroles grupā.

2) Izmeklējumu grupa: grupa ar papildu izmeklējumiem.

Iekḷautais pētījuma dalībnieku skaits Izmeklējumu grupā: 31 pacients PV grupā un 91 dalībnieks kontroles grupā.

Papildu izslēgšanas kritēriji Izmeklējumu grupai:

- $\quad$ antibiotiku lietošana pēdējo 3 mēnešu laikā;

- paracetamola lietošana pēdējo 3 dienu laikā (ietekmē rezultātus, nosakot

DHBA ar gāzu hromatogrāfiju-masspektroskopiju (GC-MS));

- $\quad$ zarnu rezekcija;

- $\quad$ iekaisīga zarnu slimība;

- caureja.

Izmeklējumu grupā netika iekḷauti dalībnieki, kuriem zināms, ka zarnu mikroflorā ir pārmaiņas (kas lietojuši antibiotikas pēdējo 3 mēnešu laikā, kam ir iekaisīga zarnu slimība, caureja vai bijusi zarnu rezekcija), jo minētajās situācijās zarnās enterolaktona veidošanās no uztura lignāniem ir traucēta [Adlercreutz, 2010]. Tika izvirzīts papildu nosacījums - pirms izmeklējumu veikšanas 3 dienas nelietot paracetamolu, jo paracetamols ietekmē DHBA rezultātus, kas tiek noteikti ar GC-MS.

Izmeklējumu grupas dalībnieki aizpildīja trīs dienu uztura dienasgrāmatu, trešajā dienā vāca 12 stundu dienas un 12 stundu nakts urīnu un ceturtās dienas rītā nodeva asins paraugus (skat. 2.3. attēlu), lai izmeklētu arī ENL un AR metabolītu koncentrāciju asins plazmā un urīnā. Asins paraugi tika nodoti pirms priekšdziedzera biopsijas (pirms antibiotiku saņemšanas).

Grafiski pētījuma shēma Izmeklējumu grupai attēlota 2.3. attēlā. 


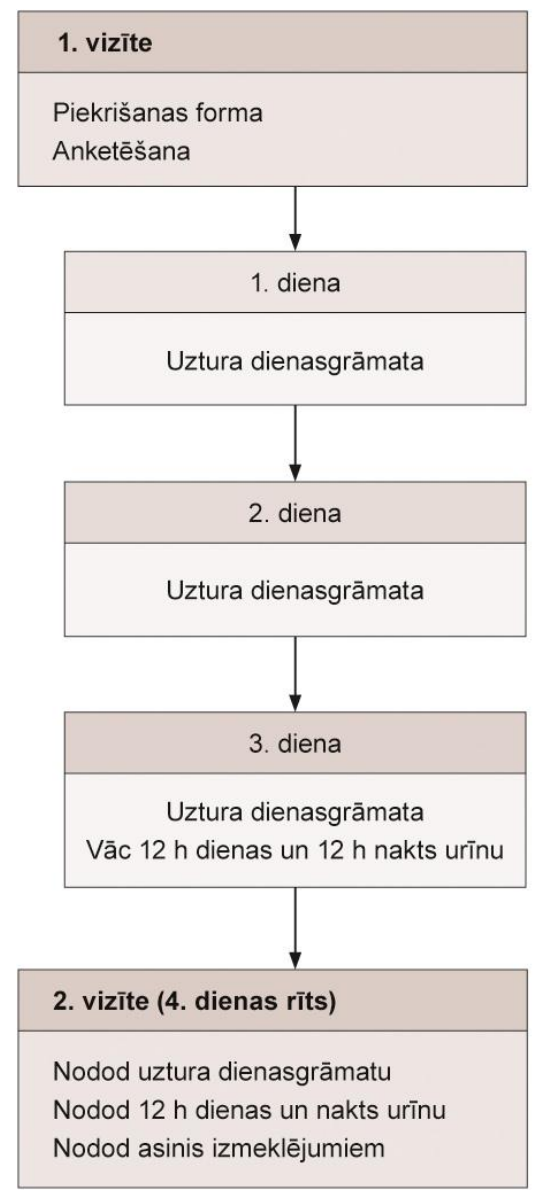

\section{3. att. Pētījuma shēma Izmeklējumu grupai}

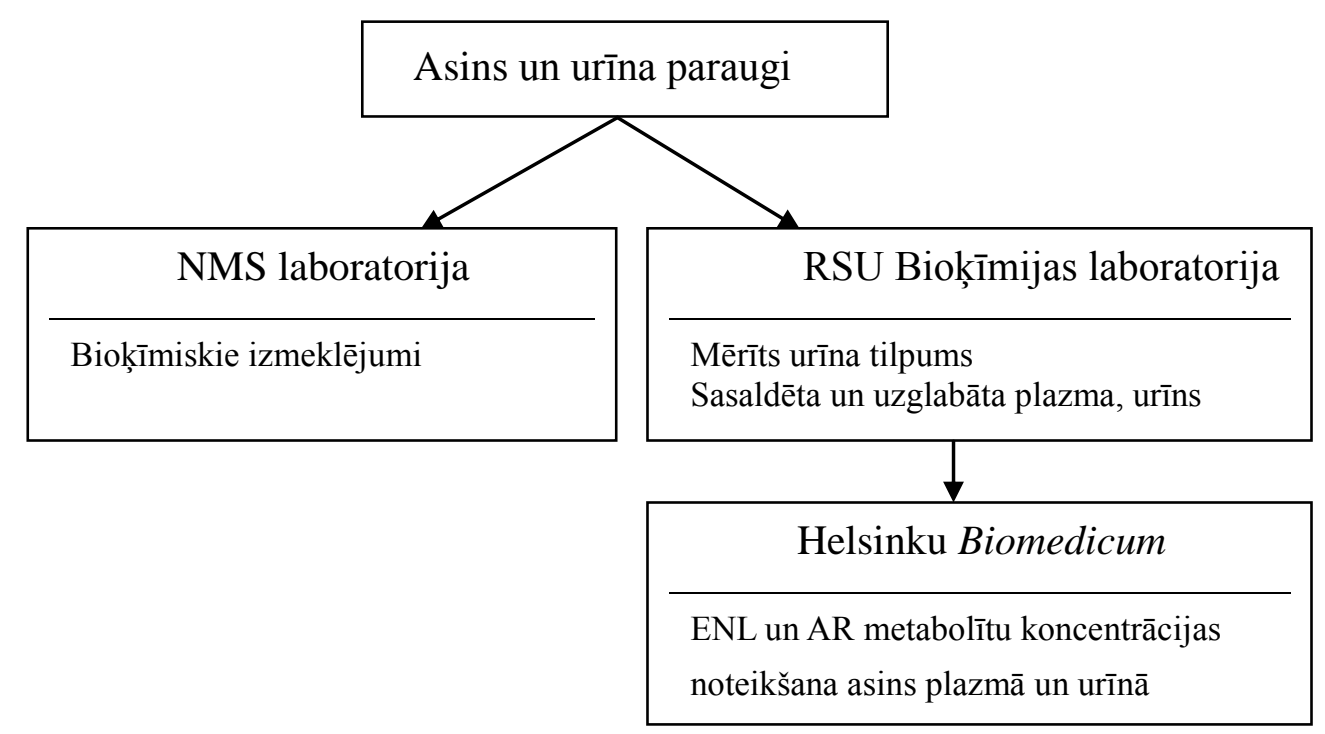

\section{4. att. Izmeklējumu veikšanas shēma Izmeklējumu grupai}

NMS - Nacionālais medicīnas serviss; Helsinku Biomedicum - Helsinku Universitātes Preventīvās medicīnas, uztura un vēža institūta Biomedicum laboratorija 
Iegūtie asins paraugi un urīns tiek nogādāts divās laboratorijās (atbildīgā par procesa atbilstību - Laila Meija, darbu veica Laila Meija un Daina Erdmane) (2.4. attēls).

Papildu izmeklējumi Izmeklējumu grupā:

- 3 dienu uztura dienasgrāmata (6. pielikums);

- Helsinku Biomedicum laboratorijā (Institute for Preventive Medicine, Nutrition, and Cancer Folkhälsan Research Center, Biomedicum Helsinki, University of Helsinki), turpmāk tekstā Helsinku Biomedicum laboratorija: DHPPA noteikšana plazmā; DHPPA 12 stundu dienas un 12 stundu nakts urīnā; DHBA 12 stundu dienas un 12 stundu nakts urīnā; ENL plazmā; ENL 12 stundu dienas un 12 stundu nakts urīnā.

- $\quad$ NMS laboratorijā: testosterons, SHBG, LH, FSH, AlAT, kreatinīns.

Sākotnēji Izmeklējumu grupā tika iekļauti 32 PV pacienti un 99 kontroles grupas dalībnieki. Veicot datu statistisko analīzi pētījumu grupai, kas rakstīja uztura dienasgrāmatu un nodeva papildu analīzes, no tālākās uztura datu statistiskās analīzes tika izslēgti tie pētījuma dalībnieki, kam uztura dienasgrāmatas datos bija neatbilstoši augsts vai zems uzṇemtās enerǵijas daudzums (< $700 \mathrm{kcal} / \mathrm{d}$ un $>4000 \mathrm{kcal} / \mathrm{d})$, izmeklējumu rezultātos bija ekstremāli augstas vērtības vai urīns tika vākts neatbilstoši pētījuma prasībām $(n=9)$. Rezultātā tika analizēti 31 pacienta dati PV grupā un 91 kontroles grupas dalībnieka dati.

Izmeklējumu grupā, analizējot rezultātus, tika izdalītas apakšgrupas gan PV, gan kontroles grupā: vīrieši, kas bija lietojuši uzturā rudzu maizi, un tie, kuri nebija lietojuši rudzu maizi uzturā trešajā uztura dienasgrāmatas rakstīšanas dienā, kā arī tie, kas bija un nebija lietojuši antibiotikas pēdējā gada laikā.

3) Atsevišķi tika analizēta grupa, kam noteikta D vitamīna koncentrācija serumā (33 PV grupā un 154 kontroles grupā). D vitamīna seruma koncentrācijas saistība ar uztura datiem tika novērtēta tikai tai daļai pētījuma dalībnieku, kam bija datu analīzei atbilstošas gada uztura biežuma aptaujas anketas (22 PV grupā un 128 kontroles grupā).

\subsubsection{Inervences pētijuma dizains}

Intervences pētījums notika, iekḷaujoties Eiropas Reǵionālā Attīstības fonda līdzfinansētā projekta 2.1.1.1. aktivitātē „Vietējas izcelsmes graudaugu sugu potenciāla 
izvērtēšana un šķirņu iegūšana izmantošanai īpašas diētiskās pārtikas produktu ieguvē" (Nr.2010/0237/2DP/2.1.1.0/10/APIA/VIAA/083).

Intervences pêtījumā iekḷauta cita atlases kopa. Pētījuma dalībnieki tika komplektēti Rīgas Austrumu KUS Latvijas Onkolog̣ijas centra ambulatorajā dạ̣ā no 2011. gada novembra līdz 2013. gada janvārim.

\section{Pētījuma dalībnieku iekļaušana intervences pētījumā}

Intervences pētījumā ar rudzu pilngraudu maizi tika iekl̦auti 38 , bet to pabeidza 37 pacienti ar histologiski apstiprinātu PV periodā pirms operatīvās terapijas vai pacienti, kuriem tika plānota cita terapijas metode.

Iekḷaušanas kritēriji:

- $\quad$ vecums - 45-80 gadi;

- dzīvo mājās, èd parasto ikdienas uzturu;

- $\quad$ PV - pirmo reizi diagnosticēts, diagnoze apstiprināta histologiski; atbilst T1/T2/T3 N0 M0 klasifikācijai;

- nav sākta PV ārstēšana (pirms operatīvās terapijas vai pacienti, kuriem tika plānota cita terapijas metode).

Izslēgšanas kritēriji:

- $\quad$ veǵetāra diēta;

- $\quad$ priekšdziedzera vēža anamnēze ǵimenē;

- antibiotiku lietošana pēdējo 3 mēnešu laikā (antibiotikas maina zarnu mikrofloru un līdz ar to arī lignānu metabolismu);

- paracetamola lietošana pēdējo 3 dienu laikā (ietekmē rezultātus, nosakot DHBA ar GC-MS);

- $\quad$ zarnu rezekcija;

- iekaisīga zarnu slimība;

- caureja;

- hroniska nieru slimība;

- hroniska aknu slimība;

- $\quad$ 1. tipa cukura diabēts;

- $\quad$ citas lokalizācijas audzējs;

- pēdējo 5 gadu laikā mainījušies ēšanas paradumi;

- $\quad$ akūti apakšējo urīnceļu simptomi. 
Pētījuma shēmu skat. 2.5. attēlā.Visiem pētījuma dalībniekiem tika nozīmēta 2 nedēlas ilga 350 g rafinētās kviešu maizes lietošana („wash out” periods), pēc tam 6 nedēlas ilga rudzu maizes lietošana $(350 \mathrm{~g})$. Pētījuma dalībniekiem tika izsniegta skaidrojoša informācija par pētījumu (7. pielikums). Pētījums notika ar speciāli izgatavotu rudzu maizi. Rezultāts tika novērtēts pēc 2 un 6 nedēḷām. Asins analīzes (no rīta, tukšā dūšā) tika nodotas pētījuma sākumā, pēc 2 un 6 nedēẹām. Šajā periodā pētījuma dalībnieki nelietoja nevienu citu maizi, izņemot pētījumam saņemto maizi. Pārējā ikdienas diēta netika mainīta. Uztura speciālists reizi nedēḷā telefoniski kontaktējās ar pêtījuma dalībniekiem, lai uzraudzītu līdzestību.

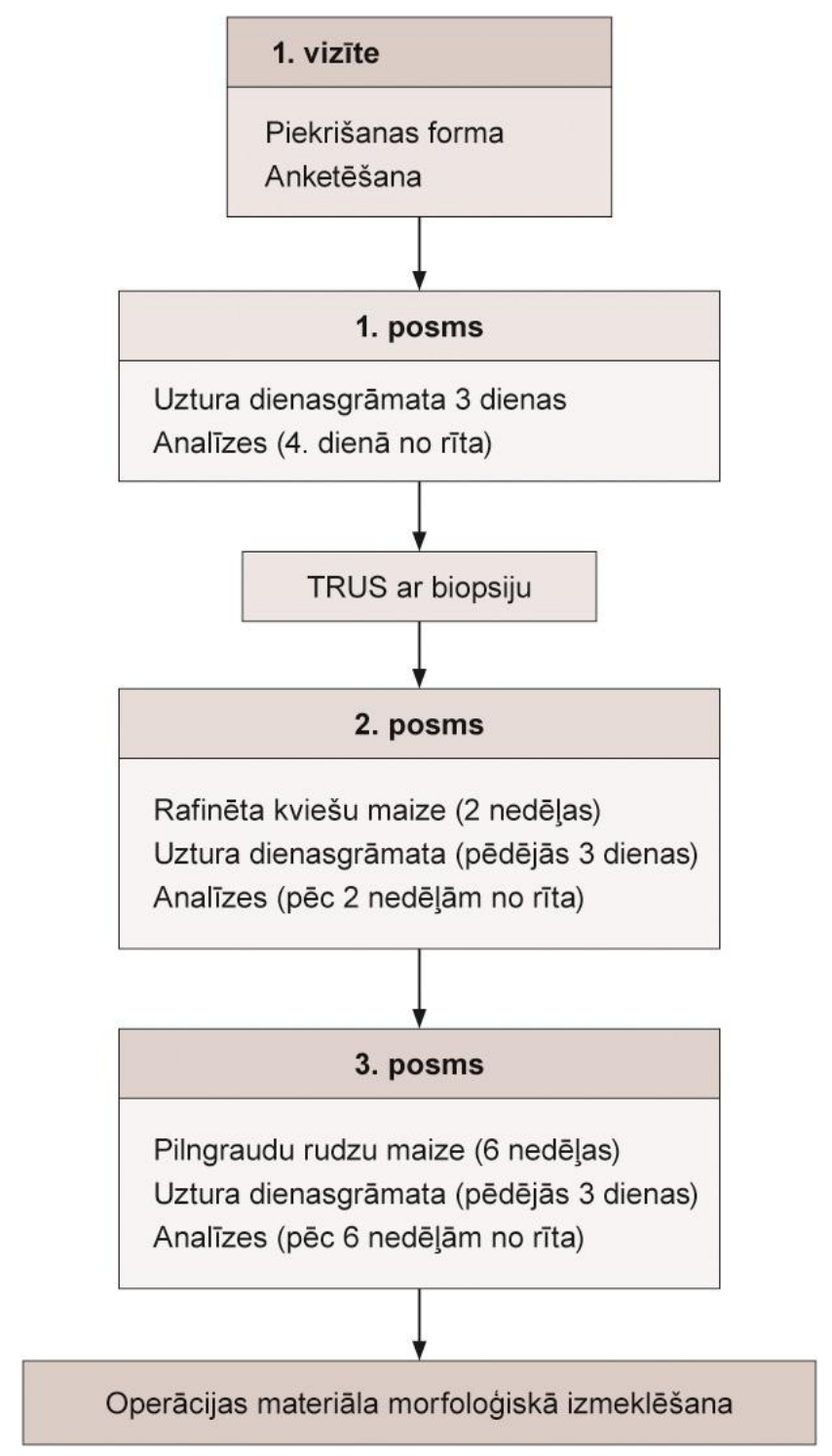

2.5. att. Intervences pētījuma shēma 
Pētījuma dalībnieki tika anketēti, lai novērtētu potenciālos PV riska faktorus, izmantojot dzīvesveida aptaujas anketu, gada uztura biežuma aptaujas anketu, un aizpildīja 3 dienu uztura dienasgrāmatu (6. pielikums) katru reizi pirms analīžu veikšanas. Morfologiiski tika izmeklēts priekšdziedzera biopsijas materiāls un operācijas (prostatektomijas) materiāls. Abos priekšdziedzera audu materiālos (priekšdziedzera vēža šūnās) tika izvērtēta apoptozes aktivitāte.

Dati par ǵimenes onkoloǵisko anamnēzi tika iegūti, aptaujājot pētîjuma dalībniekus. Informācija par blakusslimībām tika iegūta, veicot pacienta aptauju, ņemot vērā viṇa sniegto informāciju. PV diagnozi un TNM stadiju noteica urologs un patologs, ņemot vērā DRI, laboratorisko izmeklējumu, TRUS ar priekšdziedzera biopsiju rezultātus. Pētījumā piedalījās apmācīta uztura speciāliste Daina Erdmane, urologi Vilnis Lietuvietis, Māris Jakubovskis, Arkādijs Menis, Ivars Kukulis, Sergejs Beketovs, Samuels Gordins un patologs Māris Sperga.

Izmeklējumu apjoms:

- gada uztura biežuma aptaujas anketa (5. pielikums);

- dzīvesveida anketa (4. pielikums);

- uztura dienasgrāmatas (6. pielikums);

- urologa apskate, veicot DRI un TRUS (transrektāla ultrasonoskopija) ar priekšdziedzera biopsiju;

- Helsinku Biomedicum laboratorijā: DHPPA, DHBA, ENL plazmā;

- $\quad$ NMS laboratorijā: PSA; bPSA (brīvais PSA), testosterons, SHBG, LH, FSH, BAI (brīvo androgēnu indekss);

- morfologiskā izmeklēšana: priekšdziedzera biopsijas un operācijas (prostatektomijas) materiāls.

\subsection{Riska faktoru novērtēšana}

Lai novērtētu dažādus iespējamos PV riska faktorus, pētîjuma dalībnieki tika intervēti, izmantojot dzīvesveida anketu (4. pielikums). Anketa tika veidota, adaptējot Zviedrijas mamogrāfijas kohortas pētījuma (SMC87) dz̄ivesveida anketu. Anketā ietverti jautājumi par augumu, ķermeņa masu, ǵimenes stāvokli, seksuālo aktivitāti, izglītību, smēķēěanu, slimībām, medikamentu un uztura bagātinātāju lietošanu, fizisko aktivitāti dz̄ives laikā un uztura paradumiem. Dati par augumu un ķermeņa masu ir pētījuma dalībnieku pašu sniegtā informācija. 


\subsection{Uzṇemtā uztura un uzturvielu novērtēšana}

Lai izvērtētu pētījuma subjektu uztura paradumus, uzņemto pārtikas produktu un uzturvielu daudzumu pēdējā gada laikā, izmantota speciāli veidota gada uztura biežuma aptaujas anketa (5. pielikums). Anketa veidota, adaptējot Eiropas prospektīvā vēža pētījuma (EPIC: European Prospective Investigation of Cancer) uztura biežuma gada anketu [University of Cambridge, 2008a]. Izstrādes procesā pêtījuma autore konsultējās par anketas saturu un aptaujas metodiku ar Helsinku universitātes Helsinku Preventīvās medicīnas, uztura un vēža institūta Biomedicum eksperti Paivi Sēderholmu (Paivi Söderholm). Anketa veidota, ņemot vērā Latvijas iedzīvotāju uztura paradumus. Izstrādājot anketu, īpaša uzmanība pievērsta pilngraudu produktiem un tiem lignānus saturošiem produktiem, ko uzturā regulāri lieto Latvijas iedzīvotāji. Anketa ietver 159 jautājumus, iekḷaujot visas galvenās produktu un ēdienu grupas, no tiem 26 graudaugu produkti, 27 gaļas, olu un zivju produkti, 13 piena produktu veidi, 28 produkti no sakņu, dārzeņu pārtikas grupas, 13 produkti no augḷu, ogu grupas, pieci riekstu veidi, seši sēklu veidi; zupas un jaukto ēdienu grupā iekḷautas 11 sadaļas, seši saldo ēdienu veidi, dzērienu grupā ir 17 sadaļas, ieskaitot sešus alkoholiskos dzērienus, ietverti arī septiņi uztura tauku veidi. Pētījuma dalībnieki norāda, cik bieži dienas/nedēḷas/mēneša laikā lieto vai vispār nelieto attiecīgo produktu. Lai izvērtētu uzņemtā uztura daudzumu, uztura aptaujas anketa tika lietots speciāls pārtikas produktu un ēdienu porciju fotoattēlu atlants (izveidojusi Lietuvas Republikas Veselības ministrija, Pārtikas centrs un Viḷnas Universitātes Medicīnas fakultāte, latviski tulkojusi un izdevusi v/a „Sabiedrības veselības aǵentūra" [Lietuvas Republikas Veselības Aizsardzības ministrija, 2007]). Šajā bukletā ir 144 produktu dažādu lielumu porciju fotogrāfijas (8. pielikums), līdzās ir šķ̄ivja fotogrāfija dabiskā izmērā. Pētījuma dalībniekus ar aptauju iepazīstina un aptauju veic šim nolūkam speciāli apmācīts uztura speciālists.

Daļa pētîjuma dalībnieku papildus 3 dienas aizpilda speciāli izstrādātu uztura dienasgrāmatu (6. pielikums), kas adaptēta no Eiropas prospektīvā vēža pētījuma (EPIC: European Prospective Investigation of Cancer) uztura dienasgrāmatas [University of Cambridge, 2008b]. Pētījuma dalībnieki aizpildīja uztura dienasgrāmatu kopā ar ēdienu porciju lieluma novērtēšanas bukletu (8. pielikums). Uztura dienasgrāmata nepieciešama pirms asins un urīna analīžu nodošanas, jo lignānu metabolītiem ENL eliminācijas pusperiods ir 6-8 stundas, AR -5 stundas. Pētījuma dalībniekiem tika izskaidrots un izsniegta instrukcija, kā korekti aizpildīt uztura dienasgrāmatu 
(9.pielikums). Intervences pētījumā, lai novērtētu uzņemtā ēdiena daudzumu, aizpildot uztura dienasgrāmatu, katram pētījuma dalībniekam tika izsniegti pārtikas svari (Soehnle, precizitāte $1 \mathrm{~g}$ ), kā arī papildus instrukcija par ikdienas uzturu un dienasgrāmatas aizpildīšanu laikā, kad tika lietota pētījuma maize (10. pielikums).

Uztura dati tika apstrādāti Pārtikas drošības, dzīvnieku veselības un vides zinātniskajā institūtā BIOR (turpmāk tekstā BIOR) ar BIOR izveidotu programmu, kas izveidota uz Microsoft Dynamics Ax 2009 programmas bāzes. Šajā programmā izmantota BIOR Pārtikas sastāva datubāze, kas veidota ar mērķi analizēt pārtikas patēriņa datus "Latvijas iedzīvotāju visaptverošais pārtikas patēriņa pētījumā, 20072009” [Nacionālais diagnostikas centrs. PVD Pārtikas centrs, Pārtikas un veterinārā dienesta Pārtikas centrs, 2009] un šobrīd papildināta ar nepieciešamo informāciju, turpina nodrošināt datu apstrādi Latvijas iedzīvotāju pārtikas patēriņa pētījumos. BIOR Pārtikas sastāva datubāze veidota, par pamatu izmantojot Vācijas BLS, Maksa Rubnera (Max Rubner) institūtā izveidoto pārtikas sastāva datu bāzi (Bundesinstitut für gesundheitlichen Verbraucherschütz und Veterinärmedizin, Berlin, German), kas papildināta ar Latvijai raksturīgiem produktiem un receptēm. Datu bāze satur datus par 3000 produktu un ēdienu uzturvērtību. Tiek iegūts 131 uzturvērtības rādītājs. Speciāli šim pētījumam BIOR datu bāze tika papildināta ar lignānu vērtībām pārtikas produktos. Tika izmantota Kanādas lignānu datu bāze [Thompson, 2006], jo tā ir ļoti plaša un satur četru lignānu veidu (MAT, SECO, LAR, PIN) vērtības. Datu bāze tika papildināta arī ar Helsinku Universitātes Preventīvās medicīnas, uztura un vēža institūtā noteiktajām AR vērtībām [Meija, 2013a] un 6 lignānu veidu (MAT, SECO, LAR, PIN, SYR, MED) vērtībām Latvijas maizē [Meija, 2013b].

Atsevišķi tika analizētas uztura biežuma aptaujas anketa, vidējie dati no 3 dienu uztura dienasgrāmatas un trešās uztura dienasgrāmatas rakstīšanas dienas dati.

\subsection{Lignānu un alkilrezorcīnu noteikšana dažādos maizes veidos}

Izmeklējumiem tika izvēlēti visvairāk pārdotie maizes zīmoli 2008. gadā, ņemot vērā Maiznieku biedrības nepublicētus datus (personīga komunikācija ar Daigu Kunkulbergu). Maizes paraugi tika izvēlēti no katra maizes veida: rudzu, saldskābmaizes, sēklu-kliju maizes un baltmaizes. Kopā tika analizēti 9 maizes veidi. 


\section{Alkilrezorcīnu noteikšana}

Alkilrezorcīnu daudzums un homologu kompozīcija tika noteikta ar gāzu hromatogrāfiju-masspektroskopiju (GC-MS). Maizes paraugi tika sasaldēti, izžāvēti, ekstrahēti ar 1-propanololu.

\section{Izmantotie reaǵenti:}

1-propanols (Merck, Darmstadt, Germany), etilacetāts (Rathburn, Walkerburn, Scotland), trimetil-hloro-silāns (TMCS) un heksametil-disilizāns (HMDS) (Pierce, Rockford, IL, USA), piridīns (Romil, Waterbeach, Cambridge, UK), 5-n-AR standarti (C15:0, C17:0, C19:0, C21:0, C23:0, C25:0) un iekšējais standarts C20:0.

\section{Iekārtas:}

Gāzu hromatogrāfijas-masspektrometrijas iekārta, kas sastāv no Quadrupole masspektrometra Fisons MD1000, kombinēta ar Fisons GC 8000 gāzu hromatogrāfu (Fisons Instrumentation Inc., Milan, Italy). Kapilārā kolonna BP-5 (garums 12,5 m, diametrs 0,22 mm, plēves biezums 0,25 $\mu \mathrm{m}$; SGE International Pty Ltd., Ringwood, Australia).

\section{$\underline{\text { Paraugu ekstrakcija un analīze }}$}

Maizes paraugi tika saldējot žāvēti, samalti un ekstrahēti 1-propanolā [Morrisonet et al. 1984]. Kopējais AR un tā homologu sastāvs maizē tika analizēts ar gāzu hromatogrāfijas-masspektrometrijas (GC-MS) metodi, kā iekšējo standartu izmantojot AR C20:0 homologu [Ross, 2001]. Visi rezultāti iegūti, aprēķinot AR daudzumu sausnā. Katrs paraugs tika analizēts divkārši, kā rezultātu norādot vidējo lielumu.

\section{Lignānu noteikšana}

Izmantotie reaǵenti:

Lignānu standarti un to 13C3-marķētie aizstājēji iegūti no Dr. Botinga grupas (School of Chemistry, University of St. Andrews, UK), bēta-glikuronidāze (no Helix Pomatia), No G0751 (Sigma-Aldrich, Steinheim, Germany), metanols No RH1019 (Rathburn Chemicals Ltd, Walkerburn, Scotland), nātrija hidroksīda šķ̄īums No 1.09913, nātrija acetāts No 1.06268, dietilēteris No 1.00921 un etiksskābe No 1.00063 (Merck, Darmstadt, Germany), DEAE Sephadex ${ }^{\mathrm{TM} A-25 \quad \# 17-0170-02}$ (PharmaciaBiotech AB, Uppsala,Sweden), trimetil-hloro-silāns (TMCS), heksametil- 
disilizāns (HMDS) (Pierce, Rockford, IL, USA), piridīns (Romil, Waterbeach, Cambridge, $U K)$.

Iekārtas

Tika izmantota iepriekš aprakstîtā gāzu hromatogrāfijas-masspektrometrijas iekārta.

\section{$\underline{\text { Paraugu ekstrakcija un analīze }}$}

Maizes paraugi tika saldējot žāvēti, samalti un analizēti pēc modificētiem Penalvo u.c. [Penalvo JL, 2005a] un Milderes u.c. [Milder, 2004] protokoliem. Paraugu attīrīšanai pēc enzīmu hidrolīzes C18-kārtridža (Waters, Milford, MA) vietā tika izmantota ekstrakcija ar ēteri. Visi rezultāti iegūti, aprēķinot lignānu daudzumu neizžāvētā paraugā. Katrs paraugs tika analizēts divkārši, kā rezultātu norādot vidējo lielumu.

\subsection{Laboratoriskie izmeklējumi}

Pētījuma dalībniekiem asins paraugs no elkoņa vēnas (v.mediana cubiti) tika paņemts no rīta tukšā dūšā. Tika veikti šādi izmeklējumi NMS laboratorijā (atbildīgā persona: Zeltīte Rūsa). PSA tika analizēts serumā ar hemiluminiscences mikrodaļiņu imūnķīmisko metodi (Architect i2000SR, Abbott). Testosterons, SHBG, LH, FSH analizēts serumā ar imūnhemiluminiscences metodi (Immulite 2000, Siemens). D vitamīns (25 hidroksivitamīns D: 25(OH)D) serumā tika noteikts ar imūnhemiluminiscences metodi (Liaison). 25(OH)D) seruma koncentrācija $\leq 20 \mathrm{ng} / \mathrm{mL}$ tiek uzskatīta par D vitamīna deficītu, 25(OH)D) seruma koncentrācija 21-29 ng/mL par D vitamīna nepietiekamību [Holick, 2011; Latvijas Osteoporozes un kaulu metabolo slimību asociācija, 2011; Płudowski, 2013]. AlAT tika analizēts ar IFCC (International Federation of Clinical Chemistry) metodi bez piridoksāla-5 fosfāta (Architect c8000), kreatinīns tika analizēts ar Jaffes reakciju (Architect c8000).

Asins paraugi, kas paredzēti vēlākai sūtǐšanai uz Helsinkiem, tika paņemti vakuuma heparīna stobrinos (BD Vacutainer ${ }^{\circledR}, B D$, Plymouth, $\left.U K\right)$, kas uzreiz tika centrifugēti (3000 apgriezieni/min) $10 \mathrm{~min} 4{ }^{\circ} \mathrm{C}$ temperatūrā. Plazmas paraugi tika glabāti 4,5 ml kriostobriņos (CryoPure Tube, Sarstedt Ag \& Co, Numbrecht, Germany) $20{ }^{\circ} \mathrm{C}$ temperatūrā (instrukcijas 11. pielikumā).

12 stundu dienas un 12 stundu nakts urīna vākšanai un glabāšanai pētījuma dalībniekiem tika izsniegta instrukcija (12. pielikums). Urīns tika vākts 21 plastikāta 
konteineros (Sarstedt Ag \& Co, Numbrecht, Germany), kas saturēja 1 g askorbīnskābes, lai pasargātu no oksidēšanās. Urīns tika glabāts ledusskap̄ $+4{ }^{\circ} \mathrm{C}$, no rīta tika nogādāts RSU Bioķīmijas laboratorijā, kur ar cilindru tika mērīts urīna tilpums. Urīns tika glabāts 4,5 ml kriostobriņos (CryoPure Tube, Sarstedt Ag \& Co, Numbrecht, Germany) $-20{ }^{\circ} \mathrm{C}$ temperatūrā (instrukcijas 11. pielikumā). RSU bioķīmijas laboratorijā par procesu atbildēja un darbus veica Līga Lārmane. Sasaldētie urīna un plazmas paraugi tika transportēti konteineros ar sauso ledu uz Helsinku Universitātes Preventīvās medicīnas, uztura un vēža institūta Biomedicum laboratoriju.

Helsinku Universitātes Preventīvās medicīnas, uztura un vēža institūta Biomedicum laboratorijā, izmantojot augstas izšķirtspējas šķidruma hromatogrāfiju ar kulonometrisko detektoru (High performance liquid chromatography with Coulometric Electrode Array Detection: HPLC-CAD), tika noteikts DHBA, DHPPA 12 stundu dienas urīnā, 12 stundu nakts urīnā un DHPPA plazmā, izmantojot Koskelas izstrādāto metodi [Koskela, 2007; Koskela, 2008]. ENL plazmā tika noteikts šajā pašā institūtā ar laika risinājuma imunologisko fluorescences metodi (Time-Resolved Fluorescence Immunoassay method, TR-FIA), kuras pamatā ir fluorescences mērīšana [Adlercreutz, 1998; Stumf, 2000]. Intervences pētījuma dalībniekiem tika veikti tikai asins plazmas izmeklējumi (netika izmeklēts urīns).

\subsection{Morfoloğiskā izmeklēšana}

Morfologiiskā izmeklēšana tika veikta RAKUS Patologijas centrā. Priekšdziedzera biopsijas materiāls tika izvērtēts, izmantojot histologisko preparātu rutīnas (hematoksilīna un eozīna) krāsošanas metodiku. Preparāti tika mikroskopēti gaismas mikroskopā 40 x, 100 x, 200 x palielinājumos. Priekšdziedzera karcinomas malignizācijas pakāpe tika izvērtēta, nosakot to pēc Glīsona metodikas. Tā balstās uz audzēja histologiiskās arhitektūras izvērtēšanu 1-5 ballu skalā. Pēc šīs skalas tiek novērtēts gan audzēja prevalējošais komponents, gan otrs (mazāk prevalējošais) komponents. Glīsona formulā pirmais skaitlis ataino prevalējošo audzēja arhitektūru, un otrais skaitlis ataino audzēja mazāk prevalējošo (bet pēc lieluma otro vietu ieņemošo) komponentu. Šo skaitļu summa (no 2 līdz 10) ir Glīsona skaitlis [Lilleby, 2001].

Intervences pētījumā tika noteikta apoptozes aktivitāte priekšdziedzera vēža šūnās. Tika salīdzināts priekšdziedzera biopsijas materiāls ar operācijas materiālu 11 pacientiem, kuri operēti RAKUS slimnīcās. Darba posmi: 
1. Tika atlasīti reprezentatīvākie materiāli imūnhistoķīmijai. No 44 pacientiem 11 bija operēti RAKUS slimnīcās. Pēc mikroskopēšanas tika atrasti histologiskie parafīna bloki un izgatavoti jauni parafîna griezumi uz histologiskiem stikliṇiem (ar galvanizēti lādētu virsmu).

2. Imūnhistoķīmija. 3-4 mikrometrus biezi griezumi ar stikliem tika ievietoti ksilolā 10-15 min deparafinizācijai. Pēc tam slaidi tika noskaloti krāna ūdenī un veikta rehidratācija samazinātas koncentrācijas spirtos - 90\%,70\%,60\%. Pēc rehidratācijas audu paraugi tika ievietoti PBS buferī istabas temperatūrā 10 minūtes. Pēc tam preparātu pārklāja ar komplektā esošo proteināzi uz 20 minūtēm. Preparāti skaloti dejonizētā ūden̄̄ 2 reizes pa 2 minūtēm. Tad stikliṇi tika ievietoti metanola un ūdeņraža pārskābes maisījumā uz 5 minūtēm. Pēc tam preparāti tika skaloti PBS buferī uz vienu minūti. Pēc tam tika ievietoti marķējošā buferī TdT uz 5 minūtēm. Pirms reakcijas tika pagatavots marķējošā maisījuma sastāvs pēc ražotāja norādēm. Tad preparāti tika inkubēti 37 grādu temperatūrā DAKO hibridizatorā uz 5 minūtēm. Pēc tam preparāts tika apstrādāts ar reakciju bloķējošo buferi TdT. Tad preparāti tika skaloti ar dejonizētu ūdeni 2 reizes. Pēc tam preparāti tika pārklāti ar streptavidīnu - HRP kompleksu. Pirms lietošanas tika pagatavots diaminobenzidīna šksīdums (DAB) un DAB šķ̄īdums uzpilināts uz preparātiem. Pēc tam preparāti tika skaloti dejonizētā ūdenī. Piekrāsoti ar hematoksilīna krāsu un dzidrināti pieaugošas koncentrācijas etilspirtā.

3. Rezultātu izvērtēšana. Tika izvērtēta vien̄̄gi reakcija šūnu kodolos. Tika skaitītas imūnhistoķīmiski pozitīvās audzēja šūnas uz 100 kopējo audzēja šūnu skaitu 5 redzes laukos 400 x palielinājumā. Tika atzīmēts vidējais procentuālais pozitīvo šūnu daudzums. Līdztekus tam tika atzīmēts Glīsona skaitlis, audzēja T stadija, kā arī audzēja relatīvais tilpums pret priekšdziedzera tilpumu.

\subsection{Datu statistiskā analīze}

Lai aprēķinātu uzņemto uzturvielu, ieskaitot lignānu, daudzumu, uztura biežuma aptaujas anketās un uztura dienasgrāmatās iegūtie uztura dati tika apstrādāti BIOR programmā, kas paredzēta pārtikas patēriņa datu vākšanai un analīzei. Uzņemto produktu uzturvielu daudzums tika aprēķināts, ņemot vērā attiecīgā produkta porcijas lielumu (produkta patērinšs) un attiecīgo uzturvielu daudzumu $100 \mathrm{~g}$ produkta.

Uztura biežuma aptaujas anketās iegūtie dati - gan uzņemto pārtikas produktu daudzums gan uzņemto uzturvielu daudzums - tika samēroti ar vecumu, kopējo 
uzņemto enerǵijas daudzumu, izmantojot reziduālo metodi [Willet, 2013], tos transformējot (logaritmējot). Iegūtās vērtības transformētas atpakal un izmantotas tālākā analīzē. Tā kā alkohola lietošana nekorelē ar kopējo uzṇemto enerǵijas daudzumu, dati par to netika korig̣ēti attiecībā pret kopējo uzņemto kaloriju daudzumu. Uztura produktiem un vielām, laboratorisko izmeklējumu datiem aprēķinātas minimālās un maksimālās vērtības, vidējie lielumi un standartnovirze un/vai mediānie lielumi un starpkvartilu amplitūda (I kvartile un III kvartile). Datu sadalījuma raksturošanai izmantots asimetrijas koeficients un grafiskās metodes. Dati attēloti tabulās un grafikos.

Pētījuma datu salīizināšanai izmantotas neparametriskās metodes: starp grupām Manna-Vitneja (Mann-Whitney U), Vilkoksona (Wilcoxon) un hī kvadrāta (chi-square) testi un starp intervences posmiem Frīdmana (Friedman) un Vilkoksona (Wilcoxon) testi. Saistības starp metabolītiem, laboratoriskajiem izmeklējumiem un uztura produktiem novērtēšanai izmantota Spīrmena (Spearman) korelācija. P vērtība, mazāka par $\mathrm{p}<0,05$, pieņemta par statistiski ticamu. Datu statistiskā analīze veikta statistikas programmā SPSS (20.0 versija). 


\section{REZULTĀTI}

\subsection{Alkilrezorcīni un lignāni Latvijas maizē}

Lai varētu objektīvāk izvērtēt pilngraudu produktu, īpaši rudzu maizes, daudzumu uzturā un iespējamo protektîvo ietekmi, tika noteikts alkilrezorcīnu un atsevišķu to homologu daudzums 9 Latvijas maizes veidos (skat. 3.1. tab.).

3.1. tabula

Atsevišksu Latvijas maizes veidu raksturojums

\begin{tabular}{|c|c|c|c|c|c|}
\hline \multirow{2}{*}{$\begin{array}{l}\text { Maizes } \\
\text { paraugi }\end{array}$} & \multirow{2}{*}{ Maizes sastāvs } & \multicolumn{4}{|c|}{ Uzturvērtība, g/100 g } \\
\hline & & olb & tauki & ogh & kcal \\
\hline KM 1 & Kviešu milti, ūdens, cukurs, raugs, sāls, maizes uzlabotājs & 8,0 & 2,0 & 51,1 & 257,7 \\
\hline KM 2 & Kviešu milti, ūdens, cukurs, raugs, sāls, margarīns & 9,0 & 1,8 & 55,6 & 258,8 \\
\hline KSM 1 & $\begin{array}{l}\text { Kviešu milti, ūdens, saulespuķu sēklas, linsēklas, raugs, } \\
\text { margarīns, cukurs, sāls }\end{array}$ & 8,6 & 9,0 & 47,3 & 302,0 \\
\hline KSM2 & $\begin{array}{l}\text { Kviešu milti, ūdens, sezama sēklas, linsēklas, saulespuķu } \\
\text { sēklas, raugs, margarīns, cukurs, sāls }\end{array}$ & 9,8 & 11,3 & 43,7 & 314,0 \\
\hline SM 1 & $\begin{array}{l}\text { Kviešu milti, ūdens, rudzu milti, iesals, cukurs, sāls, } \\
\text { raugs, kviešu lipeklis, k̦imenes }\end{array}$ & 6,9 & 1,0 & 47,6 & 227,0 \\
\hline SM 2 & $\begin{array}{l}\text { Rudzu milti, kviešu milti, kviešu lipeklis, cukurs, raugs, } \\
\text { sāls, rudzu iesals, maizes uzlabotājs, ķimenes }\end{array}$ & 6,2 & 1,2 & 50,3 & 234,0 \\
\hline RM 1 & $\begin{array}{l}\text { Rudzu milti, ūdens, kviešu milti, cukura sīrups, rudzu } \\
\text { iesals, sāls, raugs, k̦imenes }\end{array}$ & 6,6 & 1,1 & 43,8 & 212,0 \\
\hline RM 2 & $\begin{array}{l}\text { Rudzu milti, kviešu milti, kviešu lipeklis, rudzu iesals, } \\
\text { raugs, ķimenes, maizes uzlabotājs, sāls, melase }\end{array}$ & 6,5 & 1,6 & 48,7 & 225,1 \\
\hline RM 3 & $\begin{array}{l}\text { Rudzu milti, ūdens, rudzu iesals, cukurs, sāls, raugs, } \\
\text { maizes uzlabotājs, emulgatori: E482, E472e, enzīmi }\end{array}$ & 6,5 & 1,2 & 47,7 & 231,0 \\
\hline
\end{tabular}

* dati no informācijas uz iepakojuma (2008. gadā)

KM - kviešu maize (no rafinētajiem miltiem); KSM - kviešu maize ar sēklām; SM - saldskābmaize (no jauktiem rudzu un kviešu miltiem); RM - rudzu maize; JM - jauktu miltu maize; olb - olbaltumvielas; ogh - oģ̣hidrāti

N̦emot vērā, ka Ziemel̦valstīs daudz pētîta tieši rudzu maizes protektīvā iedarbība slimību prevencijā un ārstěšanā, minētās vielas tika noteiktas arī 11 Somijas maizes veidos. AR un lignānu daudzums tika noteikts maizes veidos ar dažādu šķiedrvielu daudzumu - kviešu, rudzu, jauktu miltu maizē un kviešu miltu maizē ar pievienotām sēklām [Meija, 2013a]. 3.2. tabula atspoguḷo AR vērtîbas Latvijas un Somijas maizes veidos. Vislielākais AR daudzums bija rudzu maizē ( 560-840 $\mu \mathrm{g} / \mathrm{sausnā}$ ). Augsta AR koncentrācija bija arī tajos Somijas maizes veidos no jauktiem rudzu un kviešu miltiem ( $\sim 500-700 \mu \mathrm{g} /$ sausnā), kuros rudzu milti veido vairāk par 63\% 
no kopējā miltu sastāva un šķiedrvielu sastāvs ir augsts (10 g/100 g). Savukārt Latvijas saldskābmaizes paraugos (gatavotos no bīdelētiem rudzu un rafinētiem kviešu miltiem) AR daudzums bija ievērojami mazāks ( 200-300 $\mu \mathrm{g} /$ sausnā). Kā bija gaidāms, kviešu miltu maizē (baltmaize, gatavota no rafinētiem kviešu miltiem) bija viszemākais $A R$ daudzums ( 25-31 $\mu \mathrm{g} /$ sausnā). AR koncentrācija rudzu un kviešu maizes paraugos būtiski neatšķ̄īās Latvijas un Somijas maizes veidos. Ievērojama AR koncentrāciju atšķirība bija maizes veidos, kas gatavoti no jauktiem miltiem. To var skaidrot ar atšķirībām miltu sastāvā, ko izmanto maizes gatavošanā. Somijā izmanto pilngraudu rudzu miltus, bet Latvijā saldskābmaizes un citu jauktu miltu maizes ražošanā pārsvarā tiek izmantoti bīdelētie rudzu milti.

3.2. tabula

Alkilrezorcīnu daudzums Latvijas un Somijas maizes veidos [Meija, 2013a]

\begin{tabular}{|c|c|c|c|c|c|c|c|c|c|}
\hline \multirow[b]{2}{*}{$\begin{array}{l}\text { Maizes } \\
\text { paraugi }\end{array}$} & \multirow{2}{*}{$\begin{array}{c}\text { Šksiedrv. } \\
\text { g/100 g }\end{array}$} & \multicolumn{6}{|c|}{ AR homologi (\%) } & \multirow{2}{*}{$\begin{array}{c}\text { Kopējie AR } \\
\text { 15:0-25:0 } \\
\mu \text { g/g sausnā }\end{array}$} & \multirow{2}{*}{$\begin{array}{c}\text { AR } \\
\text { proporcija } \\
\text { 17:0 / 21:0 }\end{array}$} \\
\hline & & $15: 0$ & 17:0 & 19:0 & 21:0 & 23:0 & $25: 0$ & & \\
\hline \multicolumn{10}{|c|}{ Latvijas maize } \\
\hline KM1 & $*$ & $\mathrm{nn}$ & 7,3 & 30,6 & 42,2 & 16,3 & 3,6 & 24,7 & 0,2 \\
\hline KM 2 & $*$ & $\mathrm{nn}$ & 5,8 & 31,7 & 42,8 & 16,8 & 2,9 & 26,8 & 0,1 \\
\hline KSM 1 & 3,4 & $\mathrm{nn}$ & 5,7 & 26,1 & 42,1 & 18,6 & 7,4 & 27,7 & 0,1 \\
\hline KSM 2 & 3,9 & $\mathrm{nn}$ & 5,0 & 26,2 & 43,3 & 18,3 & 7,3 & 26,4 & 0,1 \\
\hline SM 1 & 5,2 & 0,9 & 22,5 & 28,0 & 23,9 & 14,4 & 10,3 & 217,4 & 0,9 \\
\hline SM 2 & $*$ & 0,9 & 23,9 & 25,5 & 22,4 & 16,0 & 11,4 & 298,6 & 1,1 \\
\hline RM 1 & 7,4 & 1,0 & 26,2 & 27,8 & 21,7 & 14,0 & 9,3 & 825,8 & 1,2 \\
\hline RM 2 & $*$ & 1,0 & 25,6 & 27,2 & 22,0 & 13,5 & 10,7 & 569,6 & 1,2 \\
\hline RM3 & $*$ & 1,0 & 24,9 & 26,0 & 21,8 & 15,4 & 11,0 & 651,7 & 1,1 \\
\hline \multicolumn{10}{|c|}{ Somijas maize } \\
\hline KM 1 & 3,1 & 0,2 & 5,1 & 27,8 & 44,3 & 15,4 & 7,1 & 30,8 & 0,1 \\
\hline KM 2 & 3,1 & 0,2 & 6,1 & 28,2 & 44,6 & 14,1 & 6,9 & 26,3 & 0,1 \\
\hline KM 3 & 6 & 0,1 & 5,2 & 28,1 & 45,3 & 14,0 & 7,2 & 24,9 & 0,1 \\
\hline JM 1 & 3,8 & 0,5 & 11,6 & 28,5 & 38,1 & 13,6 & 7,7 & 118,1 & 0,3 \\
\hline JM 2 & 10 & 1,2 & 26,9 & 28,6 & 20,9 & 11,6 & 10,9 & 707,0 & 1,3 \\
\hline JM 3 & 10 & 1,1 & 23,4 & 27,8 & 24,9 & 11,9 & 11,0 & 501,0 & 0,9 \\
\hline RM 1 & 13 & 1,2 & 25,8 & 27,6 & 21,0 & 12,5 & 11,9 & 831,3 & 1,2 \\
\hline RM 2 & 10 & 1,3 & 26,9 & 27,8 & 20,4 & 12,1 & 11,5 & 672,0 & 1,3 \\
\hline RM 3 & 12,2 & 1,2 & 26,0 & 27,2 & 20,7 & 12,7 & 12,3 & 840,7 & 1,3 \\
\hline RM 4 & 15 & 1,4 & 26,3 & 27,7 & 20,8 & 11,9 & 12,0 & 710,5 & 1,3 \\
\hline RM 5 & 12 & 1,3 & 27,5 & 28,7 & 20,9 & 11,1 & 10,5 & 758,7 & 1,3 \\
\hline
\end{tabular}

Šķiedrv. - šķiedrvielas (uz iepakojuma norādītais daudzums)

* škiedrvielu daudzums nav uzrādīts

KM - kviešu maize (no rafinētajiem miltiem); KSM - kviešu maize ar sēklām; SM - saldskābmaize (no jauktiem rudzu un kviešu miltiem); RM - rudzu maize; JM - jauktu miltu maize; nn - nav nosakāms 
Dažādos maizes veidos atškşīās AR homologu uzbūve. Rudzu maizē dominēja homologi C19:0; C17:0 un C21:0, savukārt kviešu maizē - C21:0 un C19:0 (3.2. tab.). AR attiecība C17:0/C21:0 bija līdzīga Latvijas un Somijas maizē: rudzu maizē 1,1-1,3, kviešu maizē $0,1-0,2$ un 0,3-1,3 maizē no jauktiem rudzu un kviešu miltiem.

Lignānu daudzums tika noteikts 9 Latvijas un 9 Somijas maizes veidos. Kā bija gaidāms, visaugstākais kopējais lignānu daudzums bija maizē ar sēklām ( 3800-10 000 $\mu \mathrm{g} / 100$ g). Rudzu maizē lignānu koncentrācija arī bija augsta $(\sim 800-1400 \mu \mathrm{g} / 100 \mathrm{~g})$. Jauktu rudzu un kviešu miltu maizē lignānu koncentrācija bija zemāka ( 500-900 $\mu \mathrm{g} / 100 \mathrm{~g}$ ), un viszemākā koncentrācija tika konstatēta rafinēto kviešu miltu maizē ( 80-100 $\mu \mathrm{g} / 100 \mathrm{~g})$. Analizējot atsevišķos lignānus, visaugstākā SECO koncentrācija bija sēklu maizē un SYR dominēja rudzu maizē (3.3. tab.).

3.3. tabula

Lignānu daudzums ( $\mu \mathrm{g} / 100 \mathrm{~g}$ mitrā svara) atsevišksos Latvijas un Somijas maizes veidos [Meija, 2013b]

\begin{tabular}{|c|c|c|c|c|c|c|c|}
\hline Lignāni & SECO & MAT & LAR & PIN & SYR & MED & Kopā \\
\hline \multicolumn{8}{|l|}{ Latvijas maize } \\
\hline Baltmaize 1 & 3,0 & $\mathrm{nn}$ & 8,4 & $\mathrm{nn}$ & 70,7 & 3,4 & 85,4 \\
\hline Baltmaize 2 & 11,4 & $\mathrm{nn}$ & 9,8 & $\mathrm{nn}$ & 80,5 & 4,0 & 105,8 \\
\hline Kviešu maize ar sēklām 1 & 7332,1 & 29,2 & 197,4 & 1230,6 & 109,7 & 27,3 & 8926,0 \\
\hline Kviešu maize ar sēklām 2 & 9442,4 & 12,8 & 196,8 & 291,2 & 95,2 & 5,9 & 10044,0 \\
\hline $\begin{array}{l}\text { Saldskābmaize (rudzu, kviešu } \\
\text { miltu) } 1\end{array}$ & 19,1 & 2,6 & 43,1 & 45,8 & 324,5 & 18,6 & 453,6 \\
\hline $\begin{array}{l}\text { Saldskābmaize (rudzu, kviešu } \\
\text { miltu) } 2\end{array}$ & 31,6 & 4,7 & 56,4 & 62,9 & 405,7 & 23,6 & 584,7 \\
\hline Rudzu maize 1 & 15,2 & 9,0 & 137,1 & 111,9 & 749,9 & 45,9 & 1069,0 \\
\hline Rudzu maize 2 & 10,3 & 6,1 & 101,4 & 80,7 & 588,6 & 33,0 & 820,1 \\
\hline Rudzu maize 3 & 13,9 & 8,1 & 141,1 & 117,8 & 682,2 & 45,7 & 1009,0 \\
\hline Vidējais CV\% $n=18$ & 10,8 & 6,6 & 2,7 & 6,0 & 3,7 & 4,5 & 34,3 \\
\hline \multicolumn{8}{|l|}{ Somijas maize } \\
\hline Baltmaize & 4,4 & 0,0 & 8,5 & 7,8 & 65,3 & 2,3 & 88,3 \\
\hline Jauktu miltu maize ar sēklām & 3565,7 & 1,7 & 39,4 & 129,5 & 95,4 & 6,6 & 3838,3 \\
\hline Jauktu miltu maize 1 & 23,4 & 8,7 & 98,0 & 140,7 & 612,9 & 22,3 & 906,1 \\
\hline Jauktu miltu maize 2 & 27,5 & 5,9 & 91,6 & 142,5 & 558,1 & 20,5 & 846,1 \\
\hline Rudzu maize 1 & 25,1 & 11,3 & 148,6 & 212,9 & 875,5 & 34,8 & 1308,2 \\
\hline Rudzu maize 2 & 24,6 & 6,9 & 80,8 & 132,9 & 601,0 & 23,7 & 869,9 \\
\hline Rudzu maize 3 & 39,2 & 13,8 & 159,2 & 246,7 & 888,9 & 34,9 & 1382,8 \\
\hline Rudzu maize 4 & 36,2 & 11,6 & 133,1 & 205,7 & 927,4 & 32,6 & 1346,4 \\
\hline Rudzu maize 5 & 23,2 & 7,7 & 103,0 & 174,4 & 645,7 & 29,6 & 983,6 \\
\hline Vidējais CV\% $\mathrm{n}=18$ & 7,3 & 4,9 & 3,8 & 6,9 & 3,4 & 6,5 & \\
\hline
\end{tabular}

MAT - matairezinols; SECO - sekoizolaricirezinols; LAR - laricirezinols; PIN - pinorezinols; SYR - siringarezinols; MED - mediorezinols; nn - nav nosakāms; CV - variācijas koeficients 
Noteiktās AR un lignānu vērtības dažādos Latvijas maizes veidos tika pievienotas BIOR pārtikas produktu datu bāzei.

\subsection{Pētījuma dalībnieku Kopējās grupas vispārīgs raksturojums}

3.4. tabula atspoguḷo Kopējās grupas dalībnieku demogrāfisko raksturojumu. No 154 pētījuma dalībniekiem 142 (92,2\%) dzīvoja Rīgā vai tās apkārtnē. Vidējais ĶMI bija 28,4 (SD 3,8) kg/m², palielināts svars vai aptaukošanās bija 81,2\% (n=125) vīriešu. Netika atrastas statistiski ticamas atšķirīibas kontroles un vēža grupā attiecībā uz tādiem parametriem kā smēķēšana, augums, onkoloǵisko slimību biežums, antibiotiku lietošana pēdējā gada laikā un seksuālā aktivitāte dzīves laikā.

Nav atrastas atšķirības fiziskajā aktivitātē. Mazaktīvi bija 9 (34,6\%) PV grupā un $60(46,9 \%)$ kontroles grupā $(p=0,118)$

3.4. tabula

Kopējās grupas vispārīgs raksturojums

\begin{tabular}{|c|c|c|c|}
\hline Pētījuma dalībnieku raksturojums & $\begin{array}{c}\text { Priekšdziedzera vēža } \\
\text { pacienti } \\
\mathbf{n}=\mathbf{2 6} \\
\mathrm{n}(\%) \\
\end{array}$ & $\begin{array}{c}\begin{array}{c}\text { Kontroles grupa } \\
\mathbf{n}=\mathbf{1 2 8} \\
\mathrm{n}(\%)\end{array} \\
\end{array}$ & $\mathbf{p}$ \\
\hline \multicolumn{4}{|l|}{ Vecums, gadi } \\
\hline $45-55$ & $3(11,5)$ & $59(46,1)$ & 0,001 \\
\hline $55-65$ & $9(34,6)$ & $43(33,6)$ & \\
\hline$>65$ & $14(53,8)$ & $26(20,3)$ & \\
\hline Vidējais (SD) & $64,9(7,8)$ & $58,3(8,5)$ & $<0,001$ \\
\hline Ķermeņa masas indekss, $\mathrm{kg} / \mathrm{m}^{2}$ & $28,4(3,1)$ & $28,4(4,0)$ & 0,821 \\
\hline$<25,0$ (normāls) & $4(15,4)$ & $25(19,5)$ & 0,616 \\
\hline 25,0-29,9 (palielināts svars) & $12(46,2)$ & $66(51,6)$ & \\
\hline$\geq 30,0$ (aptaukošanās) & $10(38,5)$ & $37(28,9)$ & \\
\hline Augums, m* & $1,77(0,07)$ & $1,77(0,06)$ & 0,877 \\
\hline \multicolumn{4}{|l|}{ Dzīvesvieta } \\
\hline Pilsēta & $25(96,2)$ & $117(92,1)$ & 0,691 \\
\hline Lauki & $1(3,8)$ & $10(7,9)$ & \\
\hline \multicolumn{4}{|l|}{ Izglītība } \\
\hline Pamatizglītība & $1(3,8)$ & $5(3,9)$ & 0,18 \\
\hline Vidējā & $3(11,5)$ & $41(32,3)$ & \\
\hline Koledžas & $11(42,3)$ & $52(40,9)$ & \\
\hline Augstākā & $11(42,3)$ & $29(22,8)$ & \\
\hline \multicolumn{4}{|l|}{ Smēķēěšana } \\
\hline Nesmēksē & $18(69,2)$ & $71(55,5)$ & 0,230 \\
\hline Bijušais smēḳētājs & $1(3,8)$ & $20(15,6)$ & \\
\hline Smēķē & $7(26,9)$ & $44(28,6)$ & \\
\hline
\end{tabular}


3.4. tabulas turpinājums

\begin{tabular}{|c|c|c|c|}
\hline Pētījuma dalībnieku raksturojums & $\begin{array}{c}\text { Priekšdziedzera } \\
\text { vēža pacienti } \\
\text { n= 26 }\end{array}$ & $\begin{array}{c}\text { Kontroles grupa } \\
\mathbf{n}=\mathbf{1 2 8}\end{array}$ & $\mathbf{p}$ \\
\hline \multicolumn{4}{|l|}{ Onkologiskās slimības ǵimenē } \\
\hline $\mathrm{Ne}$ & $14(56,0)$ & $87(68,5)$ & 0,226 \\
\hline $\mathrm{Ja}$ & $11(44,0)$ & $40(31,5)$ & \\
\hline \multicolumn{4}{|l|}{ 2. tipa cukura diabēts } \\
\hline Slimo & $1(3,8 \%)$ & $10(7,8)$ & 0,474 \\
\hline Neslimo & $25(96,2 \%)$ & $118(92,2)$ & \\
\hline \multicolumn{4}{|l|}{ Blakusslimības** } \\
\hline $\mathrm{Ne}$ & $9(34,6)$ & $62(48,4)$ & 0,197 \\
\hline $\mathrm{Ja}$ & $17(65,4)$ & $66(51,6)$ & \\
\hline \multicolumn{4}{|l|}{ Antibiotiku lietošana pēdējā gadā } \\
\hline $\mathrm{Ne}$ & $14(53,8)$ & $79(61,7)$ & 0,454 \\
\hline $\mathrm{Ja}$ & $12(46,2)$ & $49(38,3)$ & \\
\hline \multicolumn{4}{|l|}{ Seksuālā aktivitāte, reizes mēnesî̉ ${ }^{* * *}$} \\
\hline Līdz 30 gadu vecumam & $12,0(8,0 ; 16,0)$ & $12,0(8,0 ; 20,0)$ & 0,242 \\
\hline Lìdz 50 gadu vecumam & $12(7,0 ; 12,0)$ & $8,0(8,0 ; 12,0)$ & 0,826 \\
\hline Pēc 50 gadu vecuma & $6,5(3,0 ; 8,0)$ & $4,0(3,0 ; 8,0)$ & 0,790 \\
\hline Pašlaik & $1,0(0 ; 4,0)$ & $4,0(1,0 ; 8,0)$ & 0,001 \\
\hline \multicolumn{4}{|l|}{ Fiziskā aktivitāte } \\
\hline Neaktīvs & $9(34,6 \%)$ & $60(46,9 \%)$ & 0,118 \\
\hline Mēreni aktīvs & $13(50,0 \%)$ & $62(48,4 \%)$ & \\
\hline Aktīvs & $4(15,4 \%)$ & $6(4,7 \%)$ & \\
\hline
\end{tabular}

* Vidējais (SD - standartnovirze)

** Blakusslimības ietver arteriālo hipertensiju, hiperholesterinēmiju, koronāro sirds slimību, cerebrovaskulārās slimības, bronhiālo astmu,

*** Antibiotiku lietošana pēdējā gada laikā: PV grupā $\mathrm{n}=28$, kontroles $\mathrm{n}=98$

****Mediāna (starpkvartiḷu amplitūda)

\subsection{Uzṇemtais uzturs Kopējā grupā}

\subsubsection{Uztura vispārējais raksturojums}

Dati par uzņemto uzturvielu daudzumu Kopējā grupā, izmantojot uztura biežuma aptaujas anketu, atspoguļoti 3.5. tabulā.

Uzņemtais enerğijas daudzums ir statistiski ticami lielāks kontroles grupā $3304,1(2712,1 ; 3891,1) \mathrm{kcal} / \mathrm{d}$ nekā 2627,9 (2399,6; 3540,3) kcal/d PV grupā $(p=0,006)$, bet, samērojot pēc vecuma, statistiski ticamas atšķirības uzņemtajā enerǵijas daudzumā netika atrastas. Arī citu uzņemto uzturvielu daudzumā pēc samērošanas pēc vecuma netika atrastas statistiski nozīmīgas atšķirības kontroles un PV grupā $(p>0,05)$. 
3.5. tabula

Uzturvielu daudzums PV un kontroles grupas dalībnieku uzturā Kopējā grupā

\begin{tabular}{|c|c|c|c|}
\hline Uzṇemts ar uzturu & $\begin{array}{c}\text { Priekšdziedzera vēža } \\
\text { pacienti } n=26\end{array}$ & Kontroles grupa $\mathbf{n = 1 2 8}$ & $\mathbf{p}$ \\
\hline & $\begin{array}{l}\text { Mediāna (starpkvartiḷu } \\
\text { amplitūda) }\end{array}$ & $\begin{array}{l}\text { Mediāna (starpkvartiḷu } \\
\text { amplitūda) }\end{array}$ & \\
\hline $\begin{array}{l}\text { Enerğijas daudzums, } \mathrm{kcal} / \mathrm{d} \\
\mathrm{kJ} / \mathrm{d}\end{array}$ & $\begin{array}{c}2627,9(2399,6 ; 3540,3) \\
10967,2(10054,2 \\
14834,4)\end{array}$ & $\begin{array}{c}3304,1(2712,1 ; 3891,1) \\
13803,5(11329,8 ; 16304,2)\end{array}$ & 0,011 \\
\hline \multicolumn{4}{|l|}{ Uzturvielas } \\
\hline Olbaltumvielas, $\mathrm{g} / \mathrm{d}^{*}$ & $133,5(119,7 ; 159,5)$ & $138,6(123,4 ; 155,3)$ & 0,559 \\
\hline Tauki, g/d* & $127,3(109,2 ; 147,3)$ & $136,3(119,1 ; 152,4)$ & 0,194 \\
\hline Piesātinātie, g/d* & $47,1(41,0 ; 59,8)$ & $49,0(42,7 ; 57,0)$ & 0,503 \\
\hline Nepiesātinātie, g/d* & $44,6(39,4 ; 55,9)$ & $52,3(42,4 ; 57,0)$ & 0,075 \\
\hline Ogļhidrāti, g/d* & $336,9(289,0 ; 394,5)$ & $324,6(272,3 ; 359,1)$ & 0,116 \\
\hline Monosaharīdi, g/d* & $37,2(24,9 ; 48,6)$ & $39,6(27,2 ; 56,3)$ & 0,284 \\
\hline Disaharīdi, g/d* & $106,4(73,8 ; 125,3)$ & $86,4(74,1 ; 111,4)$ & 0,237 \\
\hline $\begin{array}{l}\text { Skiedrvielas, kopējās, } \\
\text { g/d* }\end{array}$ & $34,5(29,5 ; 40,1)$ & $32,8(27,3 ; 39,9)$ & 0,404 \\
\hline Nešķīstošās, $g / d^{*}$ & $22,3(18,7 ; 26,0)$ & $20,9(17,1 ; 25,3)$ & 0,449 \\
\hline Šķīstošās, g/d* & $12,8(9,4 ; 15,0)$ & $12,0(9,3 ; 14,6)$ & 0,503 \\
\hline Alkohols, g/d & $3,9(1,2 ; 7,2)$ & $4,1(1,1 ; 9,1)$ & 0,906 \\
\hline Kalcijs, g/d & $0,9(0,7 ; 1,3)$ & $1,0(0,8 ; 1,4)$ & 0,230 \\
\hline
\end{tabular}

*Samērots pēc enerǵijas

Uzṇemtā uztura dati novērtēti, izmantojot uztura biežuma aptaujas anketu

Ar olbaltumvielām abās grupās uzṇēma 18\%, ar og̣̣hidrātiem PV grupā 43\%, kontroles grupā 41\% un ar taukiem PV grupā 39\%, kontroles grupā 41\% (piesātinātie tauki abās grupās 15\%, mononepiesātinātie 14\%) no kopējā uzṇemtā energ̣ijas daudzuma. Uzņemtā enerǵija negatīvi korelē ar vecumu: $\mathrm{r}=-0,344, \mathrm{p}<0,001$ (skat. 3.1. att.). 


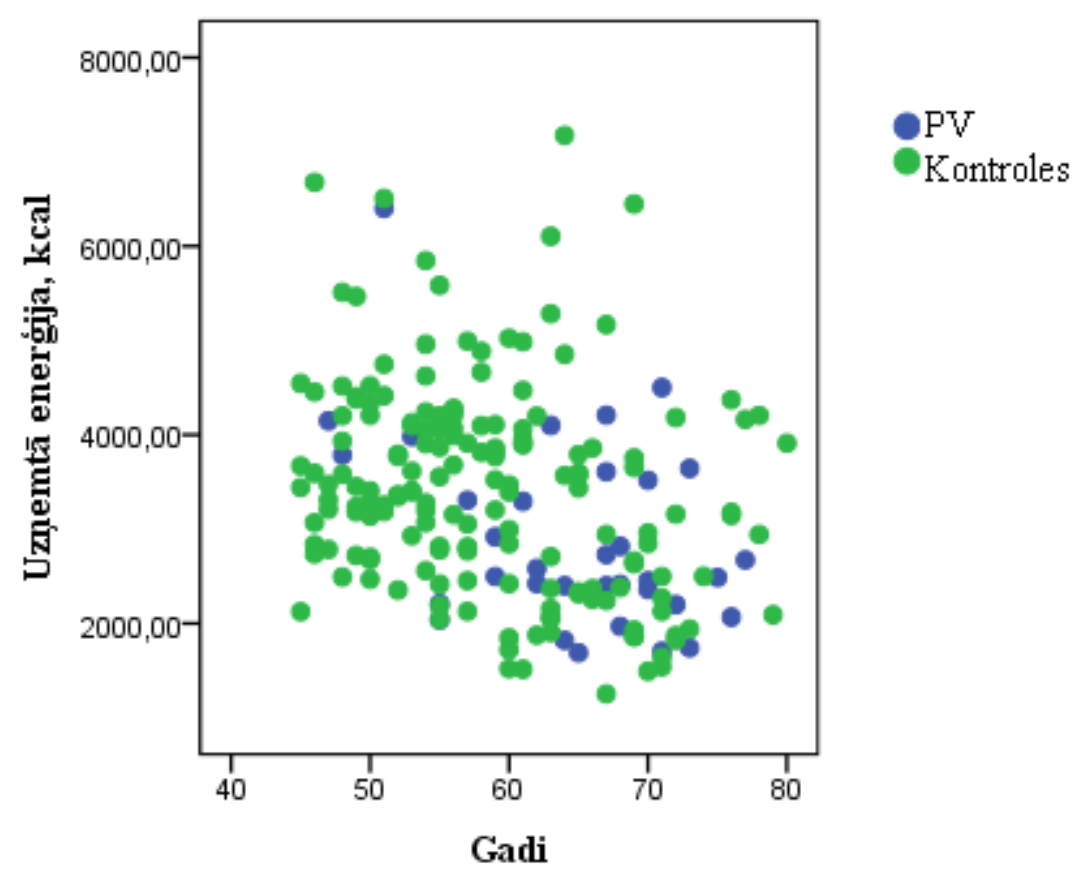

\section{1. att. Uzṇemtās enerğijas daudzums saistībā ar vecumu PV un kontroles grupā}

Netika konstatēta atšķirība šķiedrvielas/tauku attiecībā starp grupām ( $\mathrm{p}>0,05)$.

Uzturā nelietoja pienu 56\% (n=86), pākšaugus 25\% (n=39), zivis 10\% $(\mathrm{n}=16)$, tomātus 8\% (n=12), kāpostus 3\% (n=7), sēklas (linsēklas, ķirbju u.c.) 57\% (n=88) no respondentiem. Analizējot uzņemtos pārtika produktu daudzumus, netika atrastas statistiski ticamas atšķirības starp kontroles un PV grupām graudaugu produktu, zivju, piena produktu, tomātu un no tiem gatavotu produktu, augl̦u un ogu, riekstu, kafijas, tējas daudzumā uzturā. Kontroles grupas dalībnieki uzturā lieto vairāk ķiploku, kāpostu, sakņaugu un citu dārzeņu, vairāk gal̦as un saulespuķu elı̧as (skat. 3.6. tab.).

Uzņemtais uzturs tika analizēts atsevišķi divās grupās līdz un pēc 60 gadu vecuma (60 gadu vecumā mainās enerǵētiskās vajadzības [Willet, 2013]). Salīdzinot uzņemto produktu grupu un atsevišķu produktu daudzumu PV un kontroles grupā, nebija atšķirības vecuma grupās $l \bar{i} d z 60$ gadu vecumam un pēc 60 gadu vecuma $(\mathrm{p}>0,05)$. 
3.6. tabula

Atsevišķu pārtikas produktu daudzums PV pacientu un kontroles grupas dalībnieku uzturā Kopējā grupā

\begin{tabular}{|c|c|c|c|}
\hline Uzṇemts ar uzturu & $\begin{array}{c}\text { PV pacienti } \\
\mathbf{n}=26\end{array}$ & $\begin{array}{c}\text { Kontroles grupa } \\
n=128\end{array}$ & $\mathbf{p}$ \\
\hline Produktu grupas, produkti, g/d & $\begin{array}{l}\text { Mediāna (starpkvartiļu } \\
\text { amplitūda) }\end{array}$ & $\begin{array}{l}\text { Mediāna (starpkvartiļu } \\
\text { amplitūda) }\end{array}$ & \\
\hline Graudaugi & $412,5(330,9 ; 515,4)$ & $404,1(296,9 ; 550,8)$ & 0,780 \\
\hline Gaļa, gaļas produkti & $260,7(152,5 ; 356,2)$ & $304,6(238,4 ; 440,0)$ & 0,014 \\
\hline Zivis & $8,2(6,6 ; 19,2)$ & $11,8(7,4 ; 16,4)$ & 0,589 \\
\hline Piena produkti & $196,0(125,0 ; 326,7)$ & $279,1(132,5 ; 466,3)$ & 0,846 \\
\hline Saknes un citi dārzen̦i & $189,3(106,8 ; 255,9)$ & $235,0(142,2 ; 356,8)$ & 0,045 \\
\hline Tomātu produkti & $54,7(20,9 ; 69,8)$ & $41,9(19,8 ; 97,7)$ & 0,814 \\
\hline Sīpolu dzimtas augi & $22,01(13,2 ; 32,8)$ & $23,5(11,5 ; 35,0)$ & 0,601 \\
\hline Ķiploki & $2,1(0,7 ; 4,3)$ & $4,3(2,1 ; 6,4)$ & 0,010 \\
\hline Krustziežu dzimtas augi & $10,0(7,1 ; 28,5)$ & $21,6(14,2 ; 48,6)$ & 0,019 \\
\hline Kāposti & $8,2(7,1 ; 23,2)$ & $14,2(8,2 ; 35,6)$ & 0,045 \\
\hline Augl̦i un ogas & $171,7(118,3 ; 294,3)$ & $231,0(115,2 ; 454,3)$ & 0,163 \\
\hline Pākšaugi & $31,8(18,5 ; 45,2)$ & $29,3(12,2 ; 45,4)$ & 0,780 \\
\hline Rieksti & $7,7(6,4 ; 10,1)$ & $7,7(1,1 ; 8,2)$ & 0,171 \\
\hline Kafija & $250,0(200,0 ; 477,5)$ & $260,0(240,0 ; 600,0)$ & 0,243 \\
\hline Tēja & $290,7(220,1 ; 541,6)$ & $238,1(188,1 ; 500,0)$ & 0,218 \\
\hline Saulespuķu ellıa & $5,0(10,0 ; 10,0)$ & $9,8(4,3 ; 15,0)$ & 0,022 \\
\hline
\end{tabular}

Uzṇemtā uztura dati novērtēti, izmantojot gada uztura biežuma aptaujas anketu

Analizējot uzṇemto uzturu pēdējā gada laikā, tika konstatēts, ka visi pētījuma dalībnieki uzturā lietojuši maizi. Rudzu maizi PV grupā lietoja 96\% (n=25), kontroles grupā 86\% (n=111), attiecīgi baltmaizi abās grupās 92\% (n=25; n=118). Sēklu vai kliju maizi uzturā lietojuši mazāk - 65\% (n=17) PV grupā un 45\% (n=57) kontroles grupā. Nav atrastas statistiski ticamas atšķirības maizes veidā un daudzumā starp grupām (skat. 3.7. tab.). 
Maizes daudzums uzturā dienā pēdējā gada laikā PV un kontroles grupas dalībniekiem pētījuma Kopējā grupā

\begin{tabular}{|c|c|c|c|c|c|c|c|c|c|}
\hline Graudu produkts & Grupa & $\begin{array}{c}\text { Lietojuši } \\
\text { uzturā }\end{array}$ & $\begin{array}{c}\text { Nav } \\
\text { lietojuši }\end{array}$ & $\underset{\text { vērtība }}{\mathbf{p}}$ & $\begin{array}{l}\text { Mini- } \\
\text { mums, } \\
\text { g/d }\end{array}$ & $\begin{array}{c}\text { Maksi- } \\
\text { mums, } \\
\text { g/d }\end{array}$ & Vidēji (SD), g/d & $\begin{array}{c}\text { Mediānais } \\
\text { (starpkvartiḷu } \\
\text { amplitūda), g/d }\end{array}$ & p vērtība \\
\hline \multirow[t]{2}{*}{ Maize, kopā } & PV & 26 & 0 & 1,000 & 88,8 & 688,6 & $262,9(131,5)$ & $231,2(166,3 ; 371,9)$ & 0,540 \\
\hline & Kontroles & 128 & 0 & & 34,8 & 892,5 & $286,5(164,1)$ & $256,9(164,2 ; 380,4)$ & \\
\hline \multirow[t]{2}{*}{ Rudzu maize } & PV & 25 & 1 & 0,172 & 8,6 & 600,0 & $158,8(131,7)$ & $140,0(77,5 ; 175,0)$ & 0,827 \\
\hline & Kontroles & 111 & 17 & & 0,5 & 625,0 & $169,4(136,7)$ & $120,0(60,0 ; 240,0)$ & \\
\hline \multirow[t]{2}{*}{ Saldskābā maize } & PV & 7 & 19 & 0,128 & 4,1 & 150,0 & $48,6(4,9)$ & $42,7(8,5 ; 60,0)$ & 0,867 \\
\hline & Kontroles & 55 & 73 & & 0,4 & 292,5 & $60,1(6,4)$ & $45,0(8,0 ; 90,0)$ & \\
\hline \multirow[t]{2}{*}{ Baltmaize } & PV & 24 & 2 & 0,983 & 0,4 & 250,0 & $77,8(58,1)$ & $60,0(45,0 ; 89,9)$ & 0,727 \\
\hline & Kontroles & 118 & 10 & & 0,3 & 330,0 & $87,1(70,3)$ & $67,6(34,8 ; 120,0)$ & \\
\hline \multirow[t]{2}{*}{ Sēklu/ kliju maize } & PV & 17 & 9 & 0,052 & 8,6 & 150,0 & $52,3(44,7)$ & $40,0(18,2 ; 72,7)$ & 0,382 \\
\hline & Kontroles & 57 & 71 & & 0,2 & 300,0 & $70,4(62,2)$ & $60,0(19,6 ; 110,0)$ & \\
\hline
\end{tabular}

Uzṇemtā uztura dati novērtēti, izmantojot gada uztura biežuma aptaujas anketu 
Galvenais šķiedrvielu uztura avots Kopējā grupā gan PV, gan kontroles grupā bija graudaugi: 41\% no kopējā uzņemtā šķiedrvielu daudzuma. Rudzu maize ien̦ēma visnozīmīgāko lomu, veidojot $28 \%$ no kopējā uzṇemtā šķiedrvielu daudzuma un 61\% no uzṇemtā graudaugu šķiedrvielu daudzuma. Citi būtiski şķiedrvielu avoti bija saknes un citi dārzeņi, aug̣̦i (no kuriem nozīmīgākie bija āboli 6\%) un pākšaugi (skat. 3.2. attēlu).

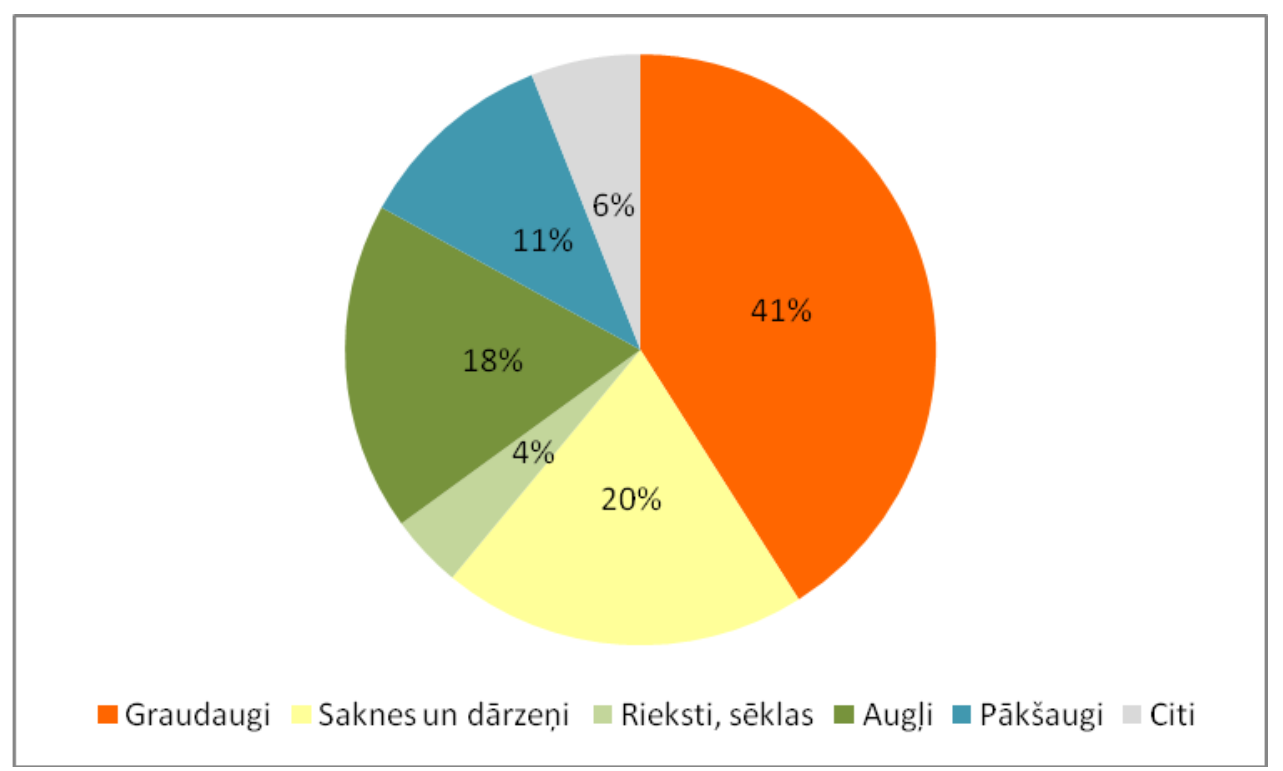

3.2. att. Šķiedrvielu avoti uzturā PV un kontroles grupas vīriešiem Kopējā grupā

Šķiedrvielu daudzums uzturā, analizējot gada uztura biežuma aptaujas anketas, negatīvi korelēja ar kopējo tauku daudzumu uzturā gan PV grupā ( $r=-0,642 ; p=0,001)$, gan kontroles grupā $(r=-0,575 ; \mathrm{p}<0,001)$. Tāpat šķiedrvielu daudzums uzturā negatīvi korelēja ar piesātināto tauku daudzumu uzturā abās pêtījuma grupās (PV grupā $\mathrm{r}=-0,605 ; \mathrm{p}=0,001$; kontroles grupā $\mathrm{r}=-0,62 ; \mathrm{p}<0,001$ ).

\subsubsection{Alkilrezorcīni uzturā Kopējā grupā}

Vidējais AR daudzums uzturā Kopējā grupā bija 72,1 (SD 62,2) mg/d; PV grupā 72,8 (SD 59,0) mg/d un kontroles grupā 71,9 $(63,1)$ mg/d. Starp PV un kontroles grupu nebija statistiski nozīmīgas atšķirības ne kopējā uzņemtā AR, ne atsevišķu AR homologu daudzumā $(p>0,05)$. 3.8. tabula atspogulso AR un atsevišķu homologu daudzumu uzturā abās pētījuma grupās. 
Alkilrezorcīnu daudzums uzturā Kopējā grupā

\begin{tabular}{c|c|c|c|c}
\hline Metabolīts & $\begin{array}{c}\text { Minimums, } \\
\text { mg/d }\end{array}$ & $\begin{array}{c}\text { Maksimums, } \\
\mathbf{m g} / \mathbf{d}\end{array}$ & $\begin{array}{c}\text { Vidēji (SD), } \\
\mathbf{m g} / \mathbf{d}\end{array}$ & $\begin{array}{c}\text { Mediāna } \\
\text { (starpkvartịlu } \\
\text { amplitūda), mg/d }\end{array}$ \\
\hline Alkilrezorcīni, kopā & 0,7 & 285,9 & $72,1(62,2)$ & $55,8(25,3 ; 98,2)$ \\
Alkilrezorcīni 15:0 & 0,0 & 2,9 & $0,7(0,6)$ & $0,6(0,2 ; 1,0)$ \\
Alkilrezorcīni 17:0 & 0,1 & 74,9 & $18,5(16,4)$ & $14,4(6,2 ; 25,3)$ \\
Alkilrezorcīni 19:0 & 0,2 & 79,4 & $20,0(17,3)$ & $15,5(7,0 ; 27,3)$ \\
Alkilrezorcīni 21:0 & 0,3 & 62,2 & $16,0(13,5)$ & $12,6(5,8 ; 21,8)$ \\
Alkilrezorcīni 23:0 & 0,1 & 39,9 & $10,1(8,7)$ & $7,9(3,6 ; 13,8)$ \\
Alkilrezorcīni 25:0 & 0,0 & 26,7 & $6,7(5,2)$ & $5,2(2,3 ; 9,1)$ \\
\hline
\end{tabular}

Uzṇemtā uztura dati novērtēti, izmantojot gada uztura biežuma aptaujas anketu

AR daudzums uzturā, analizējot uztura biežuma aptaujas anketas, abās pētījuma grupās AR daudzums uzturā korelēja ar kopējo šķiedrvielu daudzumu uzturā (PV grupā $\mathrm{r}=0,852 ; \mathrm{p}<0,001$; kontroles grupā $\mathrm{r}=0,716 ; \mathrm{p}<0,001)$, nešķīstošo šķiedrvielu daudzumu (PV grupā $r=0,814 ; p<0,001$; kontroles grupā $r=0,639 ; p<0,001$ ) un šķīstošo šksiedrvielu daudzumu daudzumu (PV grupā r=0,598; $p=0,002$; kontroles grupā $r=0,498 ; p<0,001$ ). Tāpat AR daudzums uzturā pēdējā gada laikā abās grupās korelēja ar maizes daudzumu uzturā (PV grupā $r=0,826 ; p<0,001$; kontroles grupā $r=0,773 ; p<0,001$ ) un arī atsevišķi ar rudzu maizes daudzumu uzturā (PV grupā $\mathrm{r}=0,998 ; \mathrm{p}<0,001$; kontroles grupā $r=0,986 ; p<0,001)$.

\subsubsection{Lignāni uzturā Kopējā grupā}

Analizējot uztura biežuma gada anketas Kopējā grupā, starp PV un kontroles grupām nebija statistiski nozīmīgas atšķirības ne kopējā lignānu, ne arī atsevišķo lignānu daudzumā uzturā. Mediānais lignānu daudzums uzturā abām grupām 2782 (1266-6815) $\mu \mathrm{g} / \mathrm{d}$, vidējais daudzums 5151 (SD 6364) $\mu \mathrm{g} / \mathrm{d}$. Atsevišķo lignānu daudzums uzturā atspoguḷots 3.9. tabulā. 
Lignāni PV un kontroles grupas dalībnieku uzturā

Kopējā grupā ( $\mu \mathrm{g} / \mathrm{d})$ [Meija, 2013b]

\begin{tabular}{l|c|c|c}
\hline \multicolumn{1}{c|}{ Lignāni } & \% & Vidējais (SD) & $\begin{array}{c}\text { Mediāna } \\
\text { (Starpkvartị̣u amplitūda) }\end{array}$ \\
\hline MAT & 1 & $27,8(23,0)$ & $22,6(12,6 ; 35,5)$ \\
SECO & 56 & $2885,2(5359,0)$ & $146,7(77,1 ; 3815,6)$ \\
LAR & 6 & $311,8(213,0)$ & $268,8(150,0 ; 436,3)$ \\
PIN & 13 & $652,2(833,4)$ & $351,6(174,7 ; 817,5)$ \\
SYR* & 23 & $1195,1(950,8)$ & $994,4(471,4 ; 1644,7)$ \\
MED* & 2 & $79,2(59,7)$ & $55,4(32,4 ; 111,5)$ \\
\hline
\end{tabular}

MAT - matairezinols; SECO - sekoizolaricirezinols; LAR - laricirezinols; PIN - pinorezinols;

SYR - siringarezinols; MED - mediorezinols

* analizēti tikai maizes veidos

SD standartnovirze

Abās pētījuma grupās galvenais lignānu avots uzturā bija sēklu maize un rudzu maize (kopā 86\%), linsēklas veidoja 7\%, tomēr linsēklas lietoja tikai 2\% vīriešu, bet maizi 99\% vīriešu. Pārējie lignānu uztura avoti bija nenozīmīgi (skat. 3.10. tab.).

Analizējot atsevišksu lignānu daudzumu uzturā, visvairāk tika uzņemts SECO, kura galvenie uztura avoti bija sēklu maize un linsēklas. PIN galvenie avoti uzturā bija sēklu maize, rudzu maize, sakṇaugi un citi dārzeņi, starp kuriem dominēja ķiploki. LAR un MAT uztura avoti bija rudzu un sēklu maize, savukārt SYR un MED - rudzu maize. Lignānu blīvums uzturā ( $\mu \mathrm{g} / \mathrm{kcal})$ neatšķīrās atkarībā no ĶMI, vecuma un izglītîbas līmeņa. Nesmēķētāju uzturā lignānu daudzums statistiski nozīmīgi bija lielāks nekā smēķētāju uzturā $(\mathrm{p}=0,041)$. 
Lignānu avoti uzturā vīriešiem [Meija, 2013b]

3.10. tabula

\begin{tabular}{|c|c|c|c|c|c|c|c|c|c|c|c|}
\hline & $\%$ & $\begin{array}{l}\text { MAT } \\
\mu \mathrm{g} / \mathrm{d} \text { * }\end{array}$ & $\% * *$ & $\begin{array}{c}\text { SECO } \\
\mu \mathrm{g} / \mathrm{d}\end{array}$ & $\%$ & $\begin{array}{c}\text { LAR } \\
\mu \mathrm{g} / \mathrm{d}\end{array}$ & $\%$ & $\begin{array}{l}\text { PIN } \\
\mu \mathrm{g} / \mathrm{d}\end{array}$ & $\%$ & $\begin{array}{c}\text { Kopā } \\
\mu \mathrm{g} / \mathbf{d}\end{array}$ & $\%$ \\
\hline Kopā & & $27,9(23,0)$ & & $2885,2(5359,0)$ & & $311,8(213,0)$ & & $652,2(833,4)$ & & $5151,3(6363,7)$ & \\
\hline Graudaugi & 100,0 & $22,8(21,2)$ & 82,1 & $2465,2(4691,2)$ & 85,4 & $271,6(206,9)$ & 87,1 & $575,8(790,0)$ & 88,3 & $4609,5(5765,3)$ & 89,5 \\
\hline Rudzu maize & 86,0 & $12,4(11,6)$ & 44,6 & $21,0(19,6)$ & 0,7 & $189,0(176,9)$ & 60,6 & $154,2(144,4)$ & 23,6 & $1473,5(1379,1)$ & 28,6 \\
\hline Sēklu maize & 45,3 & $9,7(18,7)$ & 34,9 & $2437,4(4692,5)$ & 84,5 & $65,6(126,3)$ & 21,0 & $409,1(787,6)$ & 62,7 & $2967,3(5712,6)$ & 57,6 \\
\hline Rieksti, sēklas & 71,5 & $0,3(1,4)$ & 1,1 & $365,2(2858,7)$ & 12,7 & $9,73(27,94)$ & 3,1 & $6,8(45,5)$ & 1,0 & $382,7(2886,3)$ & 7,4 \\
\hline Linsēklas & 2,3 & $0,2(1,2)$ & 0,5 & $358,8(2858,4)$ & 12,4 & $2,68(21,38)$ & 0,9 & $0,70(5,56)$ & 0,1 & $362,3(2886,5)$ & 7,0 \\
\hline Saulespuķu sēklas & 30,8 & $0,0(0,1)$ & 0,1 & $1,0(3,1)$ & $<0,1$ & $5,73(17,54)$ & 1,8 & $1,30(3,97)$ & 0,2 & $8,06(24,64)$ & 0,2 \\
\hline Sezama sēklas & 2,3 & $0,1(0,8)$ & 0,3 & $0,0(0,1)$ & $<0,1$ & $0,10(0,99)$ & $<0,1$ & $4,60(45,06)$ & 0,7 & $5,40(52,88)$ & 0,1 \\
\hline Dzērieni & 96,5 & $0,6(0,5)$ & 2,2 & $36,39(29,88)$ & 1,3 & $4,42(3,51)$ & 1,4 & $9,04(9,22)$ & 1,4 & $50,51(37,64)$ & 1,0 \\
\hline Kafija & 84,3 & $0,3(0,3)$ & 1,2 & $15,42(13,50)$ & 0,5 & $2,95(2,59)$ & 0,9 & $0,66(0,57)$ & 0,1 & $19,35(16,95)$ & 0,4 \\
\hline Tēja & 78,5 & $0,3(0,3)$ & 1,0 & $16,22(22,94)$ & 0,6 & $0,44(0,48)$ & 0,1 & $8,21(9,20)$ & 1,3 & $25,13(29,67)$ & 0,5 \\
\hline Alus & 25,6 & $0,0(0,0)$ & 0,0 & $0,08(0,24)$ & $<0,1$ & $0,23(0,71)$ & 0,1 & $0,12(0,36)$ & $<0,1$ & $0,43(1,31)$ & $<0,1$ \\
\hline Dārzeņi & 100,0 & $2,7(3,0)$ & 9,8 & $11,33(9,89)$ & 0,4 & $18,01(13,75)$ & 5,8 & $40,99(38,53)$ & 6,3 & $73,07(60,46)$ & 1,4 \\
\hline Kāposti & 93,0 & $0,0(0,0)$ & 0,1 & $0,69(0,76)$ & $<0,1$ & $8,54(9,46)$ & 2,7 & $11,68(12,94)$ & 1,8 & $20,91(23,16)$ & 0,4 \\
\hline Ķiploki & 95,9 & $0,3(0,3)$ & 1,0 & $2,41(2,96)$ & 0,1 & $3,13(3,83)$ & 1,0 & $27,70(33,96)$ & 4,2 & $33,52(41,09)$ & 0,7 \\
\hline Sīpoli & 99,4 & $2,3(2,7)$ & 8,2 & $5,52(6,56)$ & 0,2 & $0,08(0,09)$ & $<0,1$ & $0,20(0,24)$ & $<0,1$ & $8,09(9,61)$ & 0,2 \\
\hline Auglı un ogas & 99,4 & $1,2(1,1)$ & 4,4 & $6,40(6,68)$ & 0,2 & $7,44(6,47)$ & 2,4 & $4,88(6,08)$ & 0,7 & $19,88(17,60)$ & 0,4 \\
\hline Ogas & 91,9 & $0,0(0,0)$ & 0,1 & $2,65(4,73)$ & 0,1 & $0,92(1,64)$ & 0,3 & $0,02(0,04)$ & $<0,1$ & $3,60(6,44)$ & 0,1 \\
\hline Augli & 99,4 & $1,2(1,1)$ & 4,3 & $3,75(3,84)$ & 0,1 & $6,53(5,99)$ & 2,1 & $4,86(6,08)$ & 0,7 & $16,28(15,06)$ & 0,3 \\
\hline Olīveļ़a & 58,7 & $0,0(0,1)$ & 0,1 & $0,10(0,20)$ & $<0,1$ & $0,18(0,33)$ & 0,1 & $14,51(27,36)$ & 2,2 & $14,81(27,93)$ & 0,3 \\
\hline
\end{tabular}

Uzrādītas vidējās vērtības (SD); SD - standartnovirze; $n=172$ vīrieši

MAT - matairezinols; SECO - sekoizolaricirezinols; LAR - laricirezinols; PIN - pinorezinols

\%: norādīts, cik procentu no visiem vīriešiem lieto uzturā attiecīgo produktu

* Vidēji dienā uzñemtais daudzums $\mu \mathrm{g} / \mathrm{d}$

**Lignānu procentuālais daudzums aprēķināts, ņemot vērā lignānu daudzumu atsevišķā produktā un visos produktos kopā 
Kontroles grupā lignānu daudzums uzturā (analizējot uztura biežuma aptaujas anketas) negatīvi korelēja ar tauku daudzumu uzturā $(\mathrm{r}=-0,406 ; \mathrm{p}<0,001)$. PV grupā šāda saistība netika atrasta $(\mathrm{p}=0,171)$.

\subsection{Laboratoriskie izmeklējumi}

Mediānais PSA līmenis asins plazmā PV grupā 9,1 $(6,3 ; 14,0) \mu \mathrm{g} / \mathrm{L}$ un kontroles grupā $1,3(0,5 ; 4,6) \mu \mathrm{g} / \mathrm{L}$ bija statistiski ticami atšksirīgs $(\mathrm{p}<0,001)$. Asins plazmā dzimumhormoni, kreatinīns, AlAT starp grupām statistiski ticami neatšķīrās $(p>0,05)$. Minēto bioķīmisko izmeklējumu rezultāti atspoguḷoti 3.11. tabulā.

3.11. tabula

Laboratorisko izmeklējumu rezultāti PV un kontroles grupā

\begin{tabular}{|c|c|c|c|c|c|}
\hline Izmeklējumi & $\begin{array}{l}\text { Mini- } \\
\text { mums }\end{array}$ & $\begin{array}{l}\text { Maksi- } \\
\text { mums }\end{array}$ & $\begin{array}{l}\text { Vidējais } \\
\text { (SD) }\end{array}$ & $\begin{array}{c}\text { Mediāna } \\
\text { (I; III kvartile) }\end{array}$ & $\begin{array}{c}\text { Asimet- } \\
\text { rija }\end{array}$ \\
\hline \multicolumn{6}{|c|}{ Priekšdziedzera vēža grupa } \\
\hline PSA, $\mu \mathrm{g} / \mathrm{L}$ & 2,8 & 20,8 & $10,3(5,0)$ & $9,1(6,3 ; 14,0)$ & 0,686 \\
\hline Glīsona skaitlis & 4,0 & 8,0 & $5,6(1,2)$ & $6,0(5,0 ; 6,8)$ & 0,113 \\
\hline Kreatinīns plazmā, $\mu \mathrm{mol} / \mathrm{L}$ & 70,0 & 121,0 & $89,2(13,2)$ & $89,0(81,0 ; 97,5)$ & 0,510 \\
\hline AlAT, U/L & 12,0 & 41,0 & $24,0(9,6)$ & $21,0(16,0 ; 32,0)$ & 0,724 \\
\hline Testosterons, ng/ml & 1,4 & 8,6 & $4,7(1,6)$ & $4,6(3,3 ; 5,6)$ & 0,522 \\
\hline LH, SV/L & 2,0 & 7,2 & $3,9(1,3)$ & $3,7(2,8 ; 4,5)$ & 1,058 \\
\hline FSH, SV/L & 2,7 & 36,3 & $8,0(6,9)$ & $6,7(4,1 ; 9,0)$ & 3,253 \\
\hline $\mathrm{SHBG}, \mathrm{nmol} / \mathrm{L}$ & 15,6 & 83,0 & $41,5(16,9)$ & $38,7(28,9 ; 50,3)$ & 0,925 \\
\hline \multicolumn{6}{|c|}{ Kontroles grupa } \\
\hline PSA, $\mu \mathrm{g} / \mathrm{L}$ & 0,2 & 19,0 & $2,9(3,9)$ & $1,3(0,5 ; 4,6)$ & 2,190 \\
\hline Glīsona skaitlis & - & - & - & - & - \\
\hline Kreatinīns plazmā, $\mu \mathrm{mol} / \mathrm{L}$ & 62,0 & 110,0 & $86,1(11,2)$ & $86,5(76,5 ; 94,0)$ & 0,111 \\
\hline AlAT, U/L & 7,0 & 146,0 & $31,8(22,5)$ & $27,0(17,8 ; 35,3)$ & 2,621 \\
\hline Testosterons, ng/ml & 1,3 & 13,9 & $5,3(2,5)$ & $4,7(3,4 ; 6,6)$ & 1,498 \\
\hline LH, SV/L & 0,6 & 12,5 & $3,7(2,2)$ & $3,1(2,3 ; 4,3)$ & 1,884 \\
\hline FSH, SV/L & 1,3 & 29,5 & $6,8(4,8)$ & $5,3(3,9 ; 8,3)$ & 2,180 \\
\hline $\mathrm{SHBG}, \mathrm{nmol} / \mathrm{L}$ & 9,9 & 143,0 & $39,4(23,8)$ & $33,0(24,6 ; 45,3)$ & 2,031 \\
\hline
\end{tabular}

PSA - priekšdziedzera specifiskais antigēns

AlAT - alanīnaminotransferāze

LH - luteinizējošais hormons

FSH - folikulus stimulējošais hormons

SHBG - dzimumhormonu saistošais globulīns

SV - starptautiskās vienības 
Testosteronam abās pētījuma grupās bija negatīva korelācija ar ĶMI (PV grupā $\mathrm{r}=-0,446 ; \mathrm{p}=0,029$ un kontroles grupā attiecīgi $\mathrm{r}=-0,336 ; \mathrm{p}=0,003)$. Analizējot laboratorisko izmeklējumu datus saistībā ar gada uztura datiem, konstatējām, ka testosterona koncentrācija negatīvi korelēja ar šķīstošo šķiedrvielu daudzumu uzturā kontroles grupā $(r=-0,207 ; p=0,609)$. PV grupā šādas korelācijas nebija $(p=0,590)$. Nevienā grupā netika atrasta korelācija starp testosterona koncentrāciju un tauku, kā arī lignānu daudzumu uzturā, analizējot uztura biežuma gada anketas $(\mathrm{p}>0,05)$.

Netika atrastas arī korelācijas nevienā grupā starp SHBG koncentrāciju un olbaltumu, ogļhidrātu, tauku, piesātināto tauku un şķiedrvielu daudzumu uzturā pēdējā gada laikā $(\mathrm{p}>0,05)$.

PSA nevienā grupā nekorelēja ar lignānu daudzumu uzturā, kā arī ar kopējo, šķ̄istošo un nešķīstošo šķiedrvielu daudzumu uzturā pēdējā gada laikā $(p>0,05)$.

\subsection{Korelācija starp uztura parametriem un alkilrezorcīnu un lignānu metabolītu koncentrāciju asins plazmā un urīnā Izmeklējumu grupā}

\section{Alkilrezorcīnu metabolìti}

Uztura parametru saistība ar plazmas un urīna izmeklējumiem, kā arī AR metabolisms bioloǵiskajos şķidrumos tika analizēta 31 PV pacientam un 91 kontroles grupas dalībniekam. Šìs pētījuma daļas pacientu raksturojums atspoguḷots 3.12. tabulā.

Analizējot 3 dienu uztura dienasgrāmatas datus (vidējās vērtības no 3 dienām), netika konstatētas statistiski nozīmīgas atšksirības PV un kontroles grupā ne uzņemto pamatuzturvielu, ne arī atsevišksu maizes veidu daudzumā uzturā. Arī AR daudzumā uzturā starp abām grupām nebija statistiski nozīmīgu atšķirību (3.12. tabula).

3.12. tabula

Izmeklējumu grupas raksturojums

\begin{tabular}{|c|c|c|c|}
\hline Parametrs & $\begin{array}{c}\text { PV grupa } \\
(\mathbf{n}=31)\end{array}$ & $\begin{array}{l}\text { Kontroles grupa } \\
\qquad(\mathbf{n}=\mathbf{9 1})\end{array}$ & $\mathbf{p}$ \\
\hline & \multicolumn{2}{|c|}{ vidējais (SD) } & \\
\hline Vecums, $g$ & $65,7(7,1)$ & $62,1(8,4)$ & 0,026 \\
\hline KMI, kg/m² & $27,6(2,9)$ & $27,9(4,0)$ & 0,837 \\
\hline \multicolumn{4}{|l|}{ Uzņemts ar uzturu } \\
\hline Enerğija, kcal/d & $2174,8(699,4)$ & $2174,4(653,8)$ & 0,979 \\
\hline Olbaltumvielas, g/d* & $96,5(28,4)$ & $101,0(25,8)$ & 0,421 \\
\hline
\end{tabular}


3.12. tabulas turpinājums

\begin{tabular}{l|c|c|c}
\hline \multicolumn{1}{c|}{ Parametrs } & $\begin{array}{c}\text { PV grupa } \\
(\mathbf{n = 3 1 )}\end{array}$ & $\begin{array}{c}\text { Kontroles grupa } \\
(\mathbf{n = 9 1 )}\end{array}$ & p \\
\hline Ogļhidrāti, g/d* & $239,3(63,6)$ & $236,3(64,4)$ & 0,933 \\
Tauki, g/d* & $81,2(16,3)$ & $82,1(19,1)$ & 0,897 \\
Šķiedrvielas, g/d* & $22,0(6,4)$ & $23,3(7,7)$ & 0,385 \\
Maize, g/d* & $168,7(78,8)$ & $153,9(76,0)$ & 0,303 \\
Rudzu maize, g/d* & $125,6(79,4)$ & $104,6(65,1)$ & 0,263 \\
Rafinēta miltu kviešu maize & $51,4(36,7)$ & $63,8(50,8)$ & 0,304 \\
Sēklu-kliju maize & $72,7(59,6)$ & $51,8(45,9)$ & 0,648 \\
Lietoja rudzu maizi uzturā, \% & $25(80,6 \%)$ & $67(73,6 \%)$ & 0,433 \\
Lietoja baltmaizi uzturā, \% & $22(71,0 \%)$ & $72(79,1 \%)$ & 0,351 \\
Lietoja sēklu-kliju maizi uzturā, \% & $6(19,4 \%)$ & $20(22,0 \%)$ & 0,758 \\
Lignāni, $\mu$ g/d* & $2133,2(2359,7)$ & $1954,7(2440,2)$ & 0,383 \\
AR, mg/d & $51,1(41,3)$ & $41,5(44,2)$ & 0,134 \\
\hline
\end{tabular}

Uztura dati ir 3 dienu uztura dienasgrāmatas vidējie dati

Vidējās vērtības attiecas uz tiem, kas lietoja maizi (kontroles grupā 4 vīrieši nelietoja maizi)

* samērots pēc enerğijas

DHPPA, DHBA koncentrācijas urīnā un DHPPA koncentrācijas plazmā amplitūda atspoguḷota 3.13. tabulā.

3.13. tabula

DHPPA, DHBA koncentrācijas urīnā un DHPPA plazmas koncentrācijas amplitūda PV un kontroles grupas dalībniekiem Izmeklējumu grupā

\begin{tabular}{l|c|c}
\hline \multicolumn{1}{c|}{ Izmeklējums } & $\begin{array}{c}\text { Priekšdziedzera vēža pacienti } \\
(\mathbf{n = 3 1 )}\end{array}$ & $\begin{array}{c}\text { Kontroles grupa } \\
(\mathbf{n}=\mathbf{9 1})\end{array}$ \\
\hline DHPPA $\mu \mathrm{mol} / 24 \mathrm{~h}$ urīnā & min.-maks. & min.-maks. \\
DHPPA $\mu \mathrm{mol} / 12 \mathrm{~h}$ dienas urīnā & $5,36-90,35$ & $3,20-73,98$ \\
DHPPA $\mu \mathrm{mol} / 12$ h nakts urīnā & $2,58-43,90$ & $1,10-41,05$ \\
DHBA $\mu \mathrm{mol} / 24 \mathrm{~h}$ urīnā & $2,78-46,45$ & $1,36-32,93$ \\
DHBA $\mu \mathrm{mol} / 12 \mathrm{~h}$ dienas urīnā & $2,76-59,62$ & $0,75-44,06$ \\
DHBA $\mu \mathrm{mol} / 12 \mathrm{~h}$ nakts urīnā & $0,99-28,45$ & $0,57-27,95$ \\
DHPPA plazmā nmol/L & $1,09-31,17$ & $0,53-21,34$ \\
\hline
\end{tabular}

DHPPA - 3-(3,5-dihidroksifenil)propānskābe

DHBA - 3,5-dihidroksibenzoskābe

DHPPA un DHBA koncentrācijas 12 stundu dienas, 12 stundu nakts un diennakts urīnā neatšķīrās PV pacientiem un kontroles grupas vīriešiem. Savukārt DHPPA koncentrācija plazmā statistiski ticami augstāka bija PV grupā $(p=0,005)$ (3.14. tabula). 
3.14. tabula

DHPPA, DHBA mediānā koncentrācija urīnā un DHPPA koncentrācija plazmā PV un kontroles grupas dalībniekiem Izmeklējumu grupā

\begin{tabular}{|c|c|c|c|}
\hline Parametrs & PV pacienti $(n=31)$ & Kontroles grupa $(n=91)$ & p \\
\hline DHPPA plazmā nmol/L & $82,54(55,53 ; 122,66)$ & $62,93(35,45 ; 85,47)$ & 0,005 \\
\hline DHPPA $\mu \mathrm{mol} / 24$ h urīnā & $20,08(13,2 ; 25,87)$ & $19,03(11,82 ; 27,86)$ & 0,535 \\
\hline DHPPA $\mu \mathrm{mol} / 12 \mathrm{~h}$ dienas urīnā & $8,45(5,37 ; 12,46)$ & $8,46(5,10 ; 13,01)$ & 0,704 \\
\hline DHPPA $\mu \mathrm{mol} / 12$ h nakts urīnā & $11,2(6,64 ; 14,65)$ & $9,49(5,51 ; 13,74)$ & 0,270 \\
\hline DHBA $\mu \mathrm{mol} / 24$ h urīnā & $11,74(5,42 ; 17,91)$ & $9,56(5,26 ; 17,49)$ & 0,475 \\
\hline DHBA $\mu$ mol/12 h dienas urīnā & $5,51(2,05 ; 8,37)$ & $4,62(2,60 ; 8,61)$ & 0,800 \\
\hline DHBA $\mu$ mol/12 h nakts urīnā & $5,77(3,37 ; 11,49)$ & $5,72(3,15 ; 8,86)$ & 0,374 \\
\hline $24 \mathrm{~h}$ urīns, $\mathrm{ml}$ & $1570(1140 ; 2130)$ & $1648(1360 ; 2420)$ & 0,209 \\
\hline $12 \mathrm{~h}$ dienas urīns, $\mathrm{ml}$ & $760(600 ; 1114)$ & $900(664 ; 1230)$ & 0,155 \\
\hline $12 \mathrm{~h}$ nakts urīns, $\mathrm{ml}$ & $800(520 ; 1050)$ & $800(580 ; 1264)$ & 0,493 \\
\hline
\end{tabular}

Iekavās norādīta starpkvartiļu amplitūda.

DHPPA - 3-(3,5-dihidroksifenil) propānskābe; DHBA - 3,5-dihidroksibenzoskābe

PV grupā DHBA un DHPPA mediānā koncentrācija 12 h nakts urīnā statistiski ticami atšķīrās no $12 \mathrm{~h}$ dienas urīna (attiecīgi $\mathrm{p}=0,010$ un $\mathrm{p}=0,007$ ), savukārt kontroles grupā netika konstatēta atšksirība ne starp DHBA $(p=0,511)$, ne starp DHPPA $(p=0,417)$ dienas un nakts koncentrāciju (3.3. attēls).

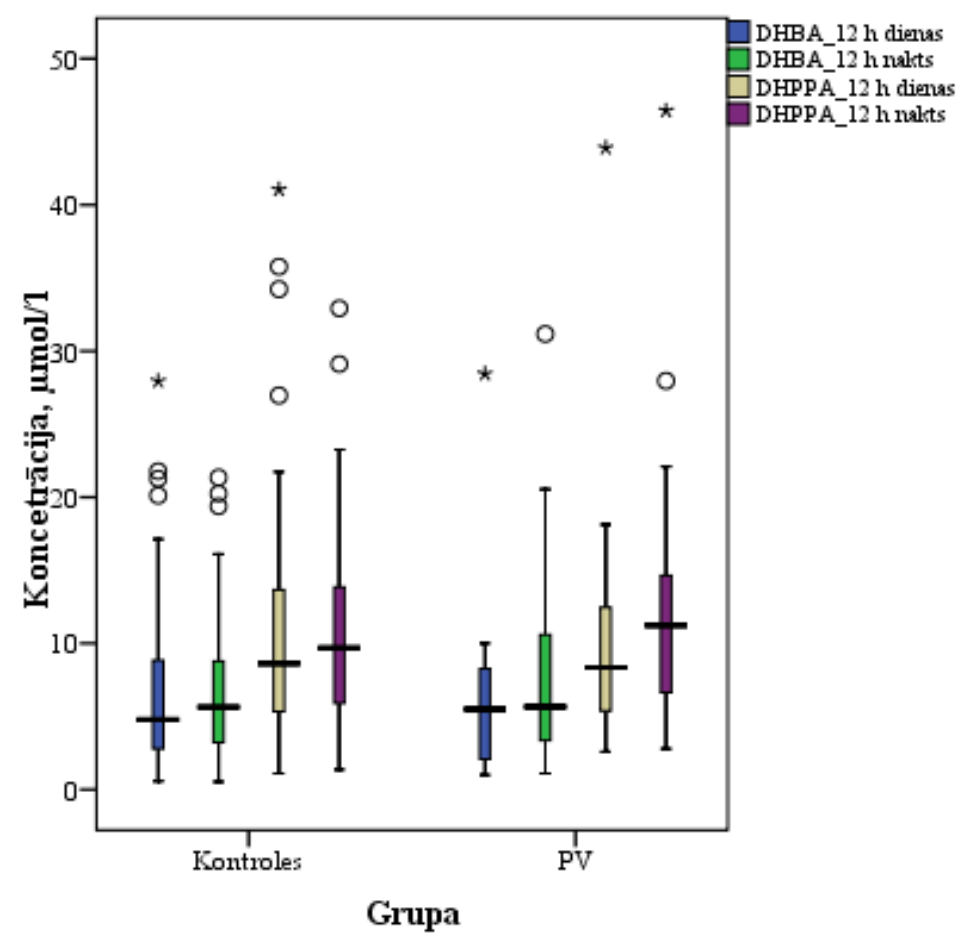

\section{3. att. DHBA un DHPPA ekskrēcija 12 stundu dienas un 12 stundu nakts urīnā PV un kontroles grupas dalībniekiem Izmeklējumu grupā}

DHPPA - 3-(3,5-dihidroksifenil) propānskābe;

DHBA - 3,5-dihidroksibenzoskābe, $\mathrm{d}$ - 12 h dienas urīns, $\mathrm{n}$ - 12 h nakts urīns 
Abās grupās DHPPA un DHBA koncentrācija $12 \mathrm{~h}$ dienas urīnā korelēja ar DHPPA un DHBA koncentrāciju 12 h nakts un 24 h urīnā (3.4. attēls).
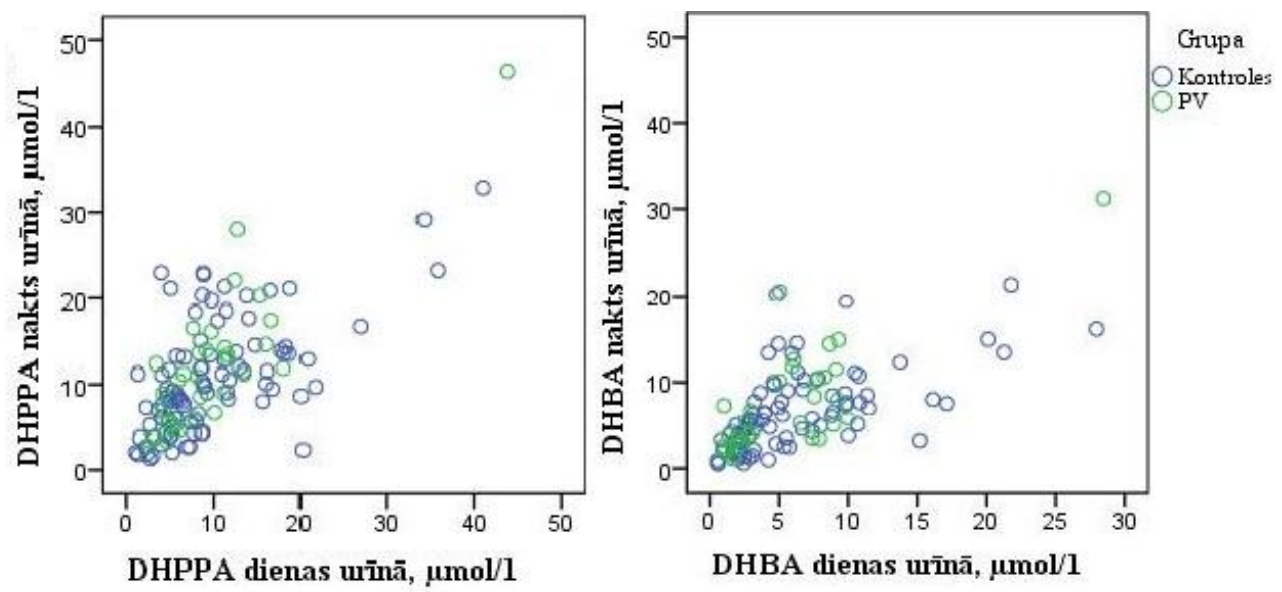

3.4. att. Korelācija starp DHPPA un DHBA koncentrāciju 12 h dienas urīnā un 12 h nakts urīnā PV pacientiem un kontroles grupas dalībniekiem Izmeklējumu grupā DHPPA - 3-(3,5-dihidroksifenil) propānskābe; DHBA - 3,5-dihidroksibenzoskābe 24 h urīnā; PV - priekšdziedzera vēža pacientu grupa

Arī DHPPA koncentrācija plazmā korelēja ar DHPPA koncentrāciju 12 h dienas, 12 h nakts un 24 h urīnā (3.5. attēls).

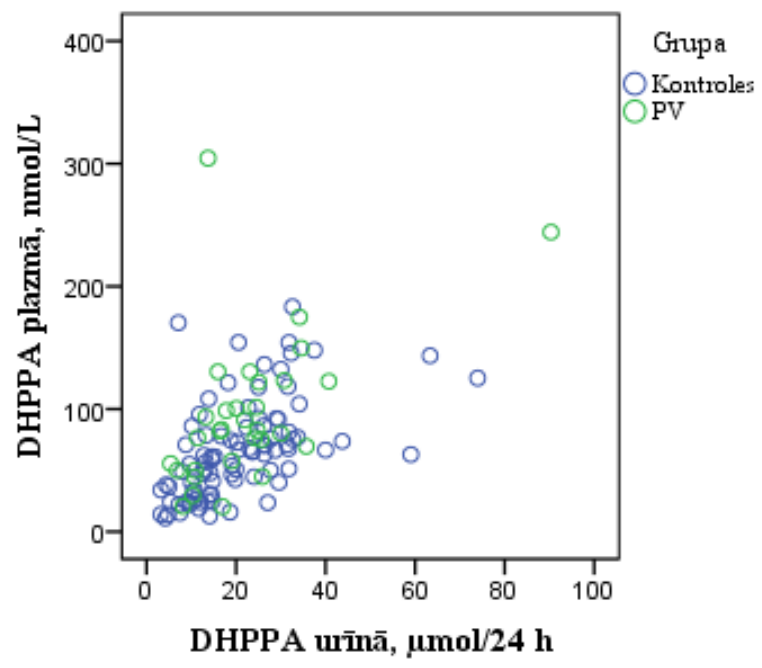

3.5. att. Korelācija starp DHPPA koncentrāciju plazmā un 24 h urīnā PV pacientiem un kontroles grupas dalībniekiem Izmeklējumu grupā DHPPA - 3-(3,5-dihidroksifenil) propānskābe 24 h urīnā; PV - priekšdziedzera vēža pacientu grupa

Korelācijas koeficienti starp DHPPA un DHBA koncentrāciju 12 h dienas urīnā un DHPPA un DHBA koncentrāciju 12 h nakts un 24 h urīnā, kā arī nozīmīguma līmenis atspoguḷots 3.15. un 3.16. tabulā. 
3.15. tabula

AR metabolītu koncentrācijas plazmā un urīnā korelācijas koeficienti PV pacientiem Izmeklējumu grupā

\begin{tabular}{l|c|c|c|c|c|c}
\hline \multicolumn{1}{c|}{ Metabolīts } & DHPPA plazmā & DHBA d & DHBA n & DHBA 24 h & DHPPA d & DHPPA n \\
\hline DHPPA plazmā & 1 & & & & & \\
DHBA d & $0,422^{*}$ & 1 & & & & \\
DHBA n & $0,446^{*}$ & $0,661^{* *}$ & 1 & & & \\
DHBA 24 h & $0,456^{* *}$ & $0,830^{* *}$ & $0,930^{* *}$ & 1 & & \\
DHPPA d & $0,458^{* *}$ & $0,859^{* *}$ & $0,633^{* *}$ & $0,771^{* *}$ & 1 & \\
DHPPA n & $0,546^{* *}$ & $0,624^{* *}$ & $0,882^{* *}$ & $0,856^{* *}$ & $0,730^{* *}$ & 1 \\
DHPPA 24 h & $0,508^{* *}$ & $0,779^{* *}$ & $0,817^{* *}$ & $0,879^{* *}$ & $0,916^{* *}$ & $0,933^{* *}$ \\
\hline
\end{tabular}

* 0. Korelācija nozīmīga līmenī 0,05

** 0 . Korelācija nozīmīga līmenī 0,01

DHPPA - 3-(3,5-dihidroksifenil)propānskābe; DHBA - 3,5-dihidroksibenzoskābe; - 12 h dienas urīns; $\mathrm{n}-12 \mathrm{~h}$ nakts urīns; $24 \mathrm{~h}-24 \mathrm{~h}$ urīns

3.16. tabula

AR metabolītu koncentrācijas plazmā un urīnā korelācijas koeficienti kontroles grupas dalībniekiem Izmeklējumu grupā

\begin{tabular}{l|c|c|c|c|c|c}
\hline \multicolumn{1}{c|}{ Metabolīts } & DHPPA plazmā & DHBA d & DHBA n & DHBA 24 h & DHPPA d & DHPPA n \\
\hline DHPPA plazmā & 1 & & & & & \\
DHBA d & $0,420^{* *}$ & 1 & & & & \\
DHBA n & $0,542^{* *}$ & $0,686^{* *}$ & 1 & & & \\
DHBA 24 h & $0,490^{* *}$ & $0,892^{* *}$ & $0,902^{* *}$ & 1 & & \\
DHPPA d & $0,520^{* *}$ & $0,826^{* *}$ & $0,590^{* *}$ & $0,767 * *$ & 1 & \\
DHPPA n & $0,582^{* *}$ & $0,517^{* *}$ & $0,832^{* *}$ & $0,684^{* *}$ & $0,605^{* *}$ & 1 \\
DHPPA 24 h & $0,618^{* *}$ & $0,733^{* *}$ & $0,779^{* *}$ & $0,812^{* *}$ & $0,863^{* *}$ & $0,903 * *$ \\
\hline
\end{tabular}

*0. Korelācija nozīmīga līmenī 0,05

***. Korelācija nozīmīga līmenī 0,01

DHPPA - 3-(3,5-dihidroksifenil)propānskābe; DHBA - 3,5-dihidroksibenzoskābe; d - 12 h dienas urīns; $\mathrm{n}-12 \mathrm{~h}$ nakts urīns; $24 \mathrm{~h}-24 \mathrm{~h}$ urīns

Uztura dati tika analizēti atsevišķi divos veidos: vidējie dati no 3 dienu uztura dienasgrāmatas un atsevišķi uztura dienasgrāmatas trešās dienas dati.

Vidējie 3 dienu uztura dienasgrāmatas dati

PV grupā tika atrastas statistiski nozīmīgas korelācijas starp DHBA koncentrāciju $12 \mathrm{~h}$ dienas, $12 \mathrm{~h}$ nakts un $24 \mathrm{~h}$ urīnā, kā arī starp DHPPA $12 \mathrm{~h}$ nakts un $24 \mathrm{~h}$ urīnā un maizes šķiedrvielu, rudzu maizes, rudzu maizes šķiedrvielu un AR daudzumu uzturā. PV grupā netika konstatēta korelācija starp DHPPA koncentrāciju $12 \mathrm{~h}$ dienas urīnā un maizes, maizes šķiedrvielu, rudzu maizes, rudzu maizes šķiedrvielu un AR daudzumu uzturā (korelācijas koeficientus un nozīmīguma līmeni skat. 3.17. tab.; DHPPA $12 \mathrm{~h}$ dienas un nakts urīna koncentrācijas korelācija ar maizes šksiedrvielu daudzumu uzturā atspoguḷota 3.6. attēlā. 

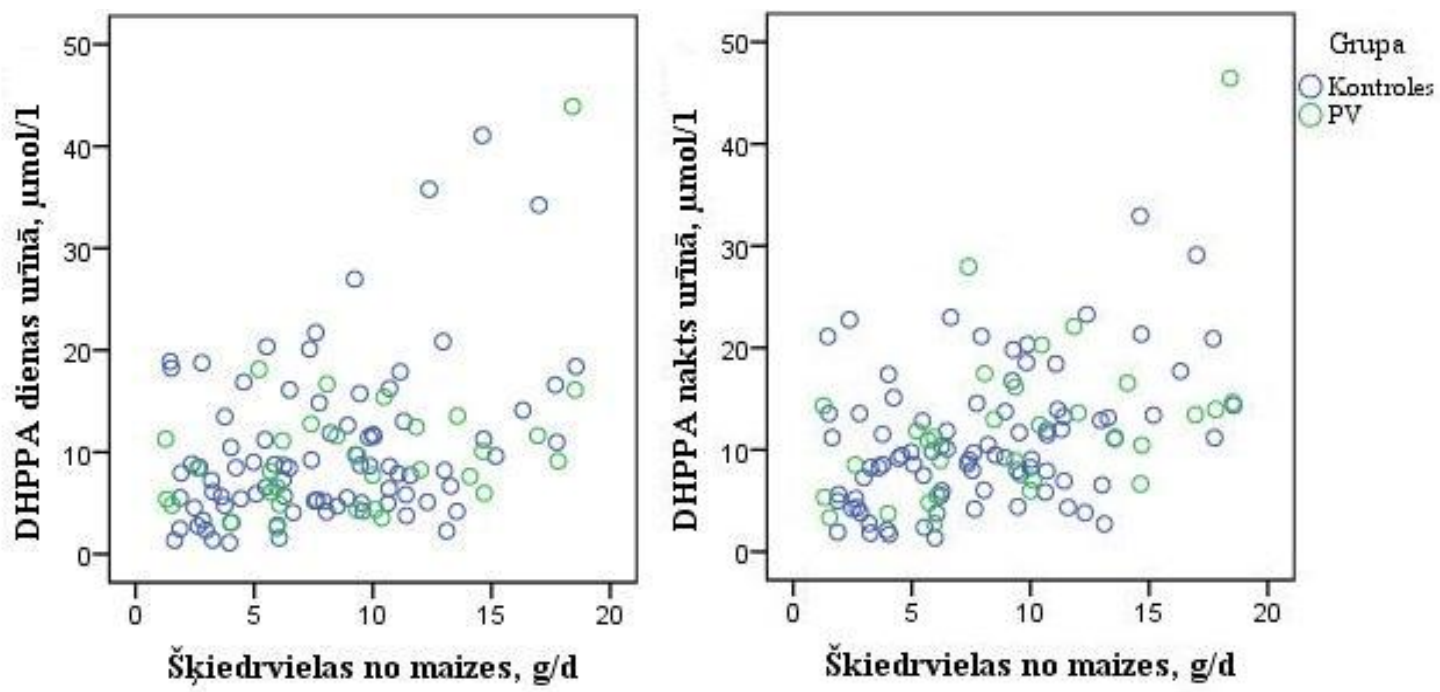

3.6. att. Korelācija starp DHPPA koncentrāciju 12 h dienas un 12 h nakts urīnā un maizes šķiedrvielu daudzumu uzturā PV pacientiem un kontroles grupas dalībniekiem

\section{Izmeklējumu grupā}

DHPPA - 3-(3,5-dihidroksifenil) propānskābe; DHPPA - 3-(3,5-dihidroksifenil)propānskābe; $\mathrm{PV}$ - priekšdziedzera vēža pacientu grupa

Kontroles grupā tika konstatētas statistiski ticamas korelācijas starp DHBA un DHPPA koncentrāciju $12 \mathrm{~h}$ dienas, $12 \mathrm{~h}$ nakts un $24 \mathrm{~h}$ urīnā un maizes, maizes šķiedrvielu un AR daudzumu uzturā. Tāpat kontroles grupā rudzu maizes un rudzu šḳiedrvielu daudzums uzturā statistiski nozīmīgi korelēja ar DHPPA koncentrāciju 12 h dienas, 12 h nakts un 24 h urīnā, kā arī ar DHBA koncentrāciju 24 h urīnā (korelācijas koeficientus un nozīmīguma līmeni skat. 3.18. tab.).

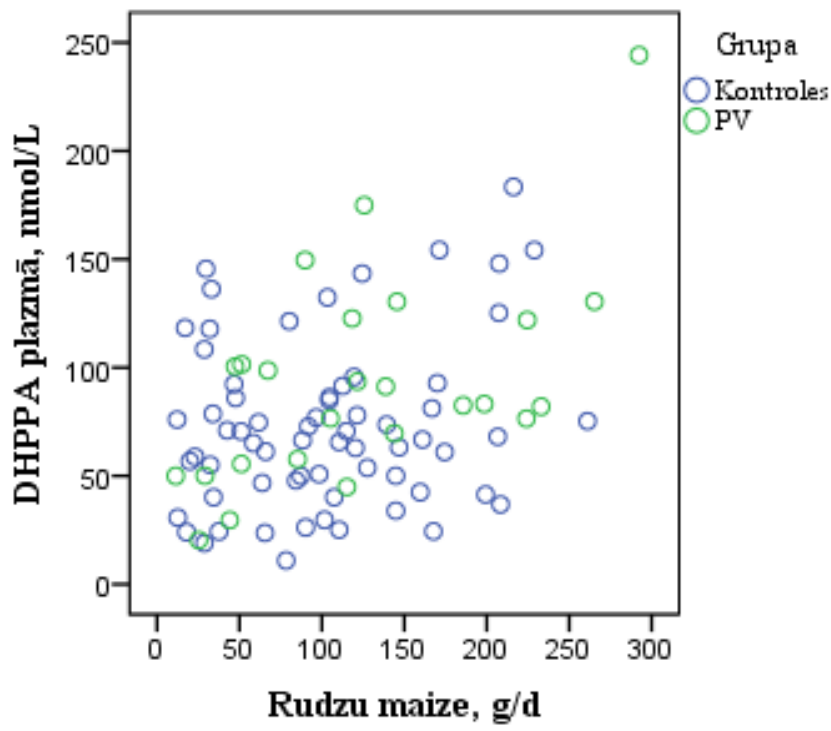

3.7. att. DHPPA plazmas koncentrācijas korelācija ar rudzu maizes daudzumu uzturā PV pacientiem un kontroles grupas dalībniekiem Izmeklējumu grupā

DHPPA - 3-(3,5-dihidroksifenil) propānskābe; PV - priekšdziedzera vēža pacientu grupa 
DHPPA plazmas koncentrācija PV grupā korelēja ar maizes, maizes šķiedrvielu, rudzu maizes un rudzu maizes šķiedrvielu daudzumu uzturā. Kontroles grupā šādas korelācijas netika atrastas (DHPPA koncentrācijas plazmā korelācija ar rudzu maizes daudzumu uzturā parādīta 3.7. attēlā). Abās grupās plazmas DHPPA korelēja ar AR daudzumu uzturā. Korelācijas koeficientus un nozīmīguma līmeni skat. 3.17 un 3.18. tab.).

3.17. tabula

AR metabolītu un uztura datu korelācijas koeficienti PV pacientiem Izmeklējumu grupā

\begin{tabular}{|c|c|c|c|c|c|c|c|}
\hline & \multicolumn{7}{|c|}{ Uztura dati: 3 dienu uztura dienasgrāmatas vidējie rādītāji } \\
\hline & $\begin{array}{l}\text { DHPPA } \\
\text { plazmā }\end{array}$ & $\begin{array}{c}\text { DHBA } \\
\mathbf{d}\end{array}$ & $\underset{\mathbf{n}}{\text { DHBA }}$ & $\begin{array}{c}\text { DHBA } \\
24 \mathrm{~h}\end{array}$ & $\begin{array}{c}\text { DHPPA } \\
\text { d }\end{array}$ & $\underset{\mathbf{n}}{\text { DHPPA }}$ & $\begin{array}{l}\text { DHPPA } \\
24 \mathrm{~h}\end{array}$ \\
\hline Maize $^{1}$ & $0,656^{*}$ & $0,426 *$ & 0,297 & 0,350 & 0,292 & $0,356^{*}$ & 0,317 \\
\hline Maizes šķiedrvielas ${ }^{1}$ & $0,607^{*}$ & $0,466^{*}$ & $0,403 *$ & $0,443 *$ & 0,336 & $0,490^{*}$ & $0,411^{*}$ \\
\hline $\begin{array}{l}\text { Rudzu maize } \\
\text { Rudzu maizes }\end{array}$ & $0,528^{*}$ & $0,417 *$ & $0,463 *$ & $0,474^{*}$ & 0,375 & $0,556^{*}$ & $0,476^{*}$ \\
\hline šķiedrvielas ${ }^{1}$ & $0,528 *$ & $0,417 *$ & $0,463 *$ & $0,474 *$ & 0,375 & $0,556^{*}$ & $0,476^{*}$ \\
\hline Alkilrezorcīni & $0,471 *$ & $0,375^{*}$ & $0,502 *$ & $0,494 *$ & 0,333 & $0,558^{*}$ & $0,450 *$ \\
\hline \multicolumn{8}{|c|}{ Uztura dati: uztura dienasgrāmatas 3.diena } \\
\hline Maize $^{1}$ & $0,468^{*}$ & 0,313 & 0,122 & 0,206 & 0,253 & 0,317 & 0,276 \\
\hline Maizes šķiedrvielas ${ }^{1}$ & 0,361 & 0,305 & 0,135 & 0,212 & 0,267 & 0,333 & 0,290 \\
\hline Rudzu maize ${ }^{1}$ & 0,334 & 0,221 & 0,152 & 0,135 & 0,335 & 0,293 & 0,260 \\
\hline $\begin{array}{l}\text { Rudzu maizes } \\
\text { šksiedrvielas }{ }^{1}\end{array}$ & 0,382 & 0,101 & 0,099 & 0,062 & 0,238 & 0,268 & 0,203 \\
\hline Alkilrezorcīni & 0,237 & 0,253 & 0,246 & 0,290 & 0,317 & $0,423^{*}$ & $0,376^{*}$ \\
\hline
\end{tabular}

*Korelācija nozīmīga līmenī 0,05

${ }^{1}$ Samērots pēc uzņemtās enerǵijas daudzuma

DHPPA - 3-(3,5-dihidroksifenil) propānskābe

DHBA - 3,5-dihidroksibenzoskābe

$\mathrm{d}-12 \mathrm{~h}$ dienas urīns

$\mathrm{n}-12 \mathrm{~h}$ nakts urīns

$24 \mathrm{~h}-24 \mathrm{~h}$ urīns 
3.18. tabula

AR metabolītu korelācijas koeficienti ar uztura datiem kontroles grupas dalībniekiem Izmeklējumu grupā

\begin{tabular}{|c|c|c|c|c|c|c|c|}
\hline & 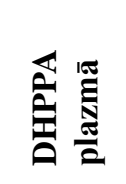 & 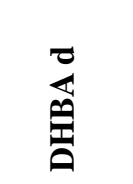 & 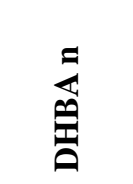 & 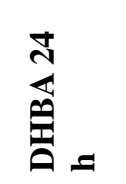 & 袅 & 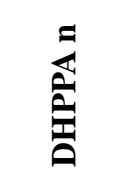 & $\frac{\sqrt{3}}{a}$ \\
\hline \multicolumn{8}{|c|}{ Uztura dati: 3 dienu uztura dienasgrāmatas vidējie rādītāji } \\
\hline Maize $^{1}$ & 0,115 & $0,283 *$ & $0,253^{*}$ & $0,287 *$ & $0,278 *$ & $0,323 *$ & $0,336^{*}$ \\
\hline Maizes šķiedrvielas ${ }^{1}$ & 0,199 & $0,350 *$ & $0,336 *$ & $0,374 *$ & $0,302 *$ & $0,350 *$ & $0,360 *$ \\
\hline Rudzu maize ${ }^{1}$ & 0,151 & 0,231 & 0,224 & $0,282 *$ & $0,247 *$ & $0,270^{*}$ & $0,285^{*}$ \\
\hline Rudzu maizes šķiedrvielas ${ }^{1}$ & 0,153 & 0,230 & 0,225 & $0,282 *$ & $0,247 *$ & $0,271 *$ & $0,285^{*}$ \\
\hline Alkilrezorcīni & $0,397 *$ & $0,458 *$ & $0,534 *$ & $0,552 *$ & $0,424^{*}$ & $0,506^{*}$ & $0,526^{*}$ \\
\hline \multicolumn{8}{|c|}{ Uztura dati: uztura dienasgrāmatas 3. diena } \\
\hline Maize $^{1}$ & 0,087 & 0,187 & $0,246^{*}$ & 0,209 & 0,18 & $0,266^{*}$ & $0,253 *$ \\
\hline Maizes šķiedrvielas ${ }^{1}$ & 0,170 & $0,330 *$ & $0,430 *$ & $0,385^{*}$ & 0,207 & $0,343^{*}$ & $0,312 *$ \\
\hline Rudzu maize ${ }^{1}$ & 0,000 & 0,260 & 0,187 & 0,236 & 0,213 & 0,203 & 0,241 \\
\hline Rudzu maizes šķiedrvielas ${ }^{1}$ & 0,031 & 0,246 & 0,199 & 0,234 & 0,158 & 0,183 & 0,199 \\
\hline Alkilrezorcīni & $0,304^{*}$ & $0,391 *$ & $0,519 *$ & $0,483 *$ & $0,368^{*}$ & $0,460 *$ & $0,471 *$ \\
\hline
\end{tabular}

* Korelācija nozīmīga līmenī 0,05

${ }^{1}$ Samērots pēc uzņemtās enerǵijas daudzuma

DHPPA - 3-(3,5-dihidroksifenil) propānskābe; DHBA - 3,5-dihidroksibenzoskābe;

$\mathrm{d}-12 \mathrm{~h}$ dienas urīns; $\mathrm{n}-12 \mathrm{~h}$ nakts urīns; $24 \mathrm{~h}-24 \mathrm{~h}$ urīns

\section{Dati no uztura dienasgrāmatas rakstǐšanas trešās dienas}

PV grupā netika atrasta korelācija starp maizes, maizes šķiedrvielu, rudzu maizes un rudzu maizes šķiedrvielu daudzumu uzturā un DHBA un DHPPA koncentrāciju $12 \mathrm{~h}$ dienas, $12 \mathrm{~h}$ nakts un $24 \mathrm{~h}$ urīnā. AR daudzums uzturā PV grupā korelēja ar DHPPA koncentrāciju 12 h nakts un 24 h urīnā (3.17. tab.).

Kontroles grupā maizes šķiedrvielu daudzums uzturā korelēja ar DHBA koncentrāciju 12 h dienas, 12 h nakts un 24 h urīnā, kā arī ar DHPPA koncentrāciju nakts un 24 h urīnā. Maizes daudzums uzturā korelēja ar DHBA un DHPPA koncentrāciju 12 h nakts un 24 h urīnā (3.18. tab.). AR daudzums uzturā 3. uztura dienasgrāmatas rakstī̌sanas dienā kontroles grupā korelēja ar DHBA un DHPPA koncentrāciju $12 \mathrm{~h}$ dienas, $12 \mathrm{~h}$ nakts un 24 h urīnā (3.18. tab.).

Analizējot DHPPA koncentrāciju plazmā saistībā ar 3. dienas uztura datiem, PV grupā tika konstatēta saistība starp DHPPA koncentrāciju plazmā un maizes daudzumu uzturā $(\mathrm{r}=468 ; \mathrm{p}<0,05)$. Savukārt kontroles grupā netika konstatēta saistība starp 
DHPPA koncentrāciju plazmā un maizes, maizes šksiedrvielu, rudzu maizes un rudzu maizes šķiedrvielu daudzumu uzturā (p>0,05) (3.17., 3.18. tab.).

Nevienā grupā, ņemot vērā 3 dienu uztura dienasgrāmatas datus, nebija korelācijas starp DHPPA koncentrāciju plazmā, kā arī DHPPA un DHBA koncentrāciju $12 \mathrm{~h}$ dienas un $12 \mathrm{~h}$ nakts urīnā un tauku daudzumu uzturā ( $\mathrm{p}>0,05)$. Savukārt, ņemot vērā tikai 3. dienas datus, kontroles grupā DHBA koncentrācija 12 h dienas urīnā korelēja ar tauku daudzumu uzturā $(r=-0,259 ; \mathrm{p}<0,05)$, kā arī DHBA koncentrācija $24 \mathrm{~h}$ urīnā korelēja ar tauku daudzumu uzturā $(\mathrm{r}=-0,253 ; \mathrm{p}<0,05)$. Analizējot trīs dienu vidējos uztura datus, DHBA koncentrācija $12 \mathrm{~h}$ dienas, nakts un $24 \mathrm{~h}$ urīnā abās pētījuma grupās korelēja ar uzņemtā alkohola daudzumu (attiecīgi PV grupā $r=-0,544$; $\mathrm{p}<0,01 ; \mathrm{r}=-0,458 ; \mathrm{p}<0,05$ un $\mathrm{r}=-0,470 ; \mathrm{p}<0,05$ un kontroles grupā $\mathrm{r}=-0,261 ; \mathrm{p}<0,05$; $\mathrm{r}=-0,278 ; \mathrm{p}<0,05$ un $\mathrm{r}=-0,236 ; \mathrm{p}<0,05)$, bet, analizējot tikai trešās dienas datus, šāda korelācija netika konstatēta $(\mathrm{p}>0,05)$.

Gan PV, gan kontroles grupā dominēja rudzu maizes lietotāji (vīrieši, kas lietojuši rudzu maizi trešajā uztura dienasgrāmatas rakstīšanas dienā). PV grupā netika konstatēta statistiski ticama atšķirība starp DHPPA koncentrāciju plazmā tiem, kas uzturā bija lietojuši rudzu maizi, un starp tiem, kuri nebija $(p=0,680)$, turpretī kontroles grupā atšķirīibas bija statistiski nozīmīgas (p<0,001) (3.8. att.).

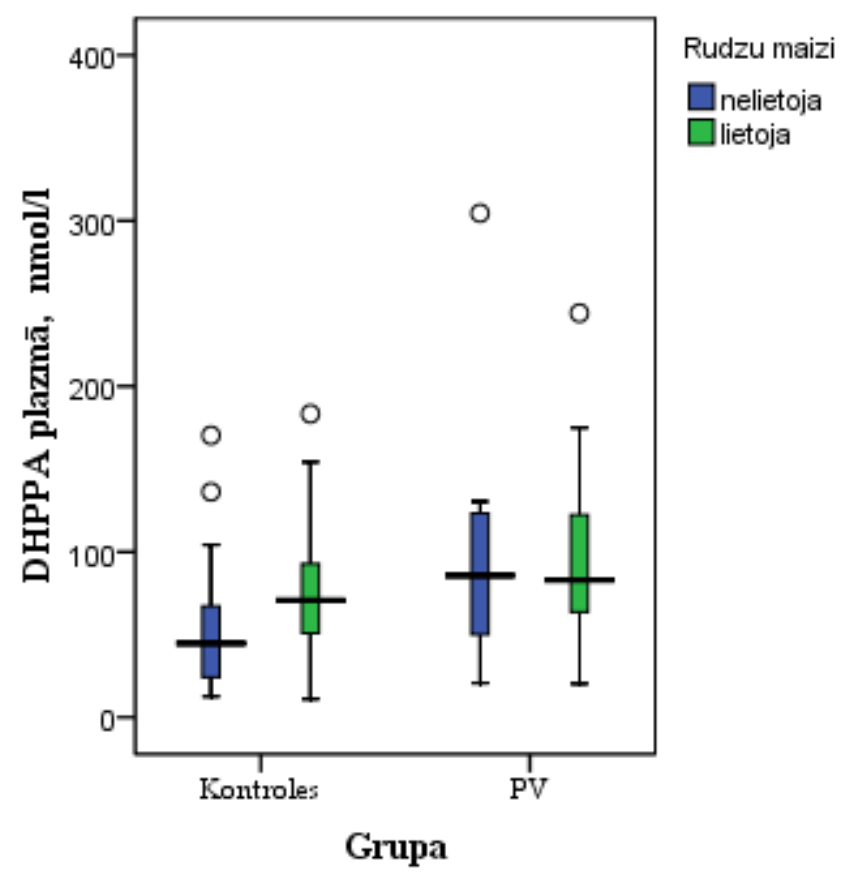

3.8. att. DHPPA koncentrācija plazmā rudzu maizes lietotājiem un nelietotājiem PV pacientu un kontroles grupā pētījuma Izmeklējumu grupā

DHPPA - 3-(3,5-dihidroksifenil) propānskābe; PV - priekšdziedzera vēža pacientu grupa 
Līdzīgi arī DHBA un DHPPA koncentrācija $12 \mathrm{~h}$ dienas, $12 \mathrm{~h}$ nakts un $24 \mathrm{~h}$ urīnā PV grupā neatšksīīās starp tiem, kas bija lietojuši rudzu maizi, un tiem, kuri nebija $(\mathrm{p}>0,05)$, bet kontroles grupā atšķirības bija statistiski nozīmīgas. Starp rādītājiem grupām, kas lietojuši un kas nebija lietojuši rudzu maizi uzturā, DHPPA un DHBA koncentrāciju 12 h nakts 24 h urīnā - atšķirības nozīmīguma līmenis p bija $<0,001$; starp rādītājiem - DHBA koncentrācija 12 h dienas urīnā $p=0,002$ un DHPPA koncentrācija $12 \mathrm{~h}$ dienas urīnā $-\mathrm{p}=0,001$ (3.9. att.).
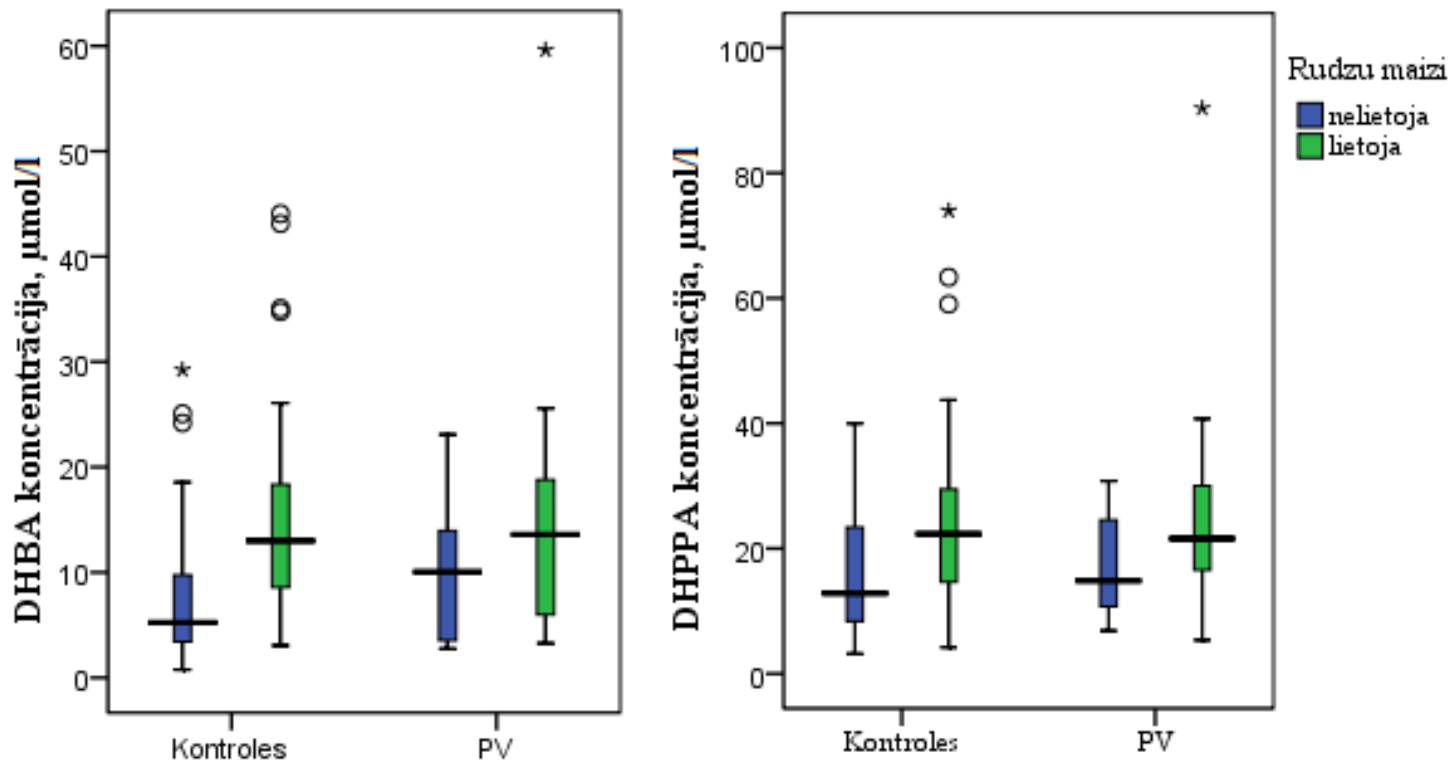

Grupa

3.9. att. DHPPA un DHBA koncentrācija 24 stundu urīnā rudzu maizes lietotājiem un nelietotājiem PV pacientu un kontroles grupā pētījuma Izmeklējumu grupā

DHPPA - 3-(3,5-dihidroksifenil) propānskābe 24 h urīnā; DHBA -3,5-dihidroksibenzoskābe 24 h urīnā; PV - priekšdziedzera vēža pacientu grupa

Netika konstatēta saistība starp glomerulārās filtrācijas ātrumu (GFĀ) un DHPPA koncentrāciju plazmā, kā arī DHPPA un DHBA koncentrāciju 12 h dienas, 12 h nakts un 24 h urīnā.

\section{Enterolaktons}

ENL koncentrācija $12 \mathrm{~h}$ dienas, $12 \mathrm{~h}$ nakts urīnā, $24 \mathrm{~h}$ urīnā un plazmā tika noteikta 31 pacientam PV grupā un 91 kontroles grupas dalībniekam. Šīs pētījuma grupas raksturojums atspoguḷots 3.12. tabulā. Starp abām grupām netika konstatēta statistiski nozīmīga atšķirība ne uzṇemtās sēklu, ne rudzu maizes, ne arī lignānu 
daudzuma ziņā (skat. 3.12. tab.). Lignānu mediānais daudzums uzturā bija 2133,6 (587,0-2441,7) $\mu \mathrm{g} / \mathrm{d}$ PV grupā un 1213,5 (393,4-21422) $\mu \mathrm{g} / \mathrm{d}$ kontroles grupā.

ENL koncentrācijas amplitūda $12 \mathrm{~h}$ dienas, $12 \mathrm{~h}$ nakts, $24 \mathrm{~h}$ urīnā un plazmā atspoguḷota 3.19. tabulā.

3.19. tabula

Enterolaktona koncentrācijas amplitūda urīnā un plazmā PV pacientu un kontroles grupā pētījuma Izmeklējumu grupā

\begin{tabular}{l|c|c}
\hline \multicolumn{1}{c|}{ Metabolīts } & $\begin{array}{c}\text { Priekšdziedzera vēža } \\
\text { pacienti }(\mathbf{n = 3 1})\end{array}$ & Kontroles grupa $(\mathbf{n = 9 1 )}$ \\
\hline ENL $\mu \mathrm{mol} / 12 \mathrm{~h}$ dienas urīnā & $0,29-11,42$ & $0,08-19,26$ \\
ENL $\mu \mathrm{mol} / 12 \mathrm{~h}$ nakts urīnā & $0,17-8,10$ & $0,00-33,05$ \\
ENL $\mu \mathrm{mol} / 24 \mathrm{~h}$ urīnā & $0,17-19,53$ & $0,00-52,31$ \\
ENL plazmā, nmol/L & $1,77-214,10$ & $0,45-134,62$ \\
\hline
\end{tabular}

ENL - enterolaktons

Izvērtējot ENL koncentrācijas 12 h dienas, 12 h nakts, 24 h urīnā un plazmā, starp abām pētījuma grupām netika konstatētas statistiski nozīmīgas atšķirības (3.20. tab.).

3.20. tabula

Enterolaktona mediānā koncentrācija urīnā un plazmā PV un kontroles grupas dalībniekiem Izmeklējumu grupā

\begin{tabular}{l|c|c|c}
\hline \multicolumn{1}{c|}{ Metabolīts } & PV pacienti $(\mathbf{n = 3 1})$ & Kontroles grupa $(\mathbf{n = 9 1})$ & p \\
\hline ENL $\mu \mathrm{mol} / 12$ h dienas urīnā & $1,84(1,17 ; 2,89)$ & $1,39(0,83 ; 2,82)$ & 0,381 \\
ENL $\mu \mathrm{mol} / 12$ h nakts urīnā & $1,59(1,06 ; 2,90)$ & $1,49(0,55 ; 3,16)$ & 0,424 \\
ENL $\mu \mathrm{mol} / 24 \mathrm{~h}$ urīnā & $3,49(2,02 ; 5,51)$ & $2,79(1,40 ; 5,73)$ & 0,417 \\
ENL plazmā, nmol/L & $29,17(14,33 ; 48,49)$ & $26,41(14,87 ; 43,97)$ & 0,646 \\
\hline
\end{tabular}

ENL - enterolaktons

Iekavās norādīta starpkvartiḷu amplitūda

Abās pētījuma grupās visi ENL koncentrācijas rādītāji (ENL 12 h dienas, 12 h nakts, 24 h urīnā un plazmā) korelēja viens ar otru (korelāciju koeficientu un nozīmīguma līmeni skat. 3.21. un 3.22. tab.). 
3.21. tabula

Enterolignāna koncentrācijas plazmā un urīnā korelācijas koeficienti kontroles grupas dalībniekiem Izmeklējumu grupā

\begin{tabular}{l|c|c|c}
\hline \multicolumn{1}{c|}{ Metabolīts } & $\begin{array}{c}\text { ENL } \boldsymbol{\mu m o l} / \mathbf{1 2} \mathbf{h} \\
\text { dienas urīnā }\end{array}$ & $\begin{array}{c}\text { ENL } \boldsymbol{\mu m o l} / \mathbf{1 2} \mathbf{h} \\
\text { nakts urīnā }\end{array}$ & $\begin{array}{c}\text { ENL } \boldsymbol{\mu m o l} / \mathbf{2 4} \mathbf{h} \\
\text { urīnā }\end{array}$ \\
\hline ENL $\mu \mathrm{mol} / 12 \mathrm{~h}$ dienas urīnā & 1 & & \\
ENL $\mu \mathrm{mol} / 12 \mathrm{~h}$ nakts urīnā & $0,797 * *$ & 1 & \\
ENL $\mu \mathrm{mol} / 24 \mathrm{~h}$ urīnā & $0,932^{* *}$ & $0,953^{* *}$ & 1 \\
ENL plazmā $(\mathrm{nmol} / \mathrm{L})$ & $0,615^{* *}$ & $0,797 * *$ & $0,953^{* *}$ \\
\hline
\end{tabular}

ENL - enterolaktons; **0. Korelācija nozīmīgā līmenī 0,001

3.22. tabula

Enterolignāna koncentrācijas plazmā un urīnā korelācijas koeficienti PV grupā Izmeklējumu grupā

\begin{tabular}{l|c|c|c}
\hline \multicolumn{1}{c|}{ Metabolīts } & $\begin{array}{c}\text { ENL } \boldsymbol{\mu m o l} / \mathbf{1 2} \text { h } \\
\text { dienas urīnā }\end{array}$ & $\begin{array}{c}\text { ENL } \boldsymbol{\mu m o l} / \mathbf{1 2} \\
\text { h nakts urīnā }\end{array}$ & $\begin{array}{c}\text { ENL } \boldsymbol{\mu m o l} / \mathbf{2 4} \text { h } \\
\text { urīnā }\end{array}$ \\
\hline ENL $\mu \mathrm{mol} / 12 \mathrm{~h}$ dienas urīnā & 1 & & \\
ENL $\mu \mathrm{mol} / 12 \mathrm{~h}$ nakts urīnā & $0,767 * *$ & 1 & \\
ENL $\mu \mathrm{mol} / 24 \mathrm{~h}$ urīnā & $0,931^{* *}$ & $0,944 * *$ & 1 \\
ENL plazmā $(\mathrm{nmol} / \mathrm{L})$ & $0,579 * *$ & $0,681^{* *}$ & $0,688^{* *}$ \\
\hline
\end{tabular}

ENL - enterolaktons; **Korelācija nozīmīga līmenī 0,001

3.10. attēlā atspogulota ENL koncentrācijas korelācija starp 12 stundu dienas un 12 stundu nakts urīnu.

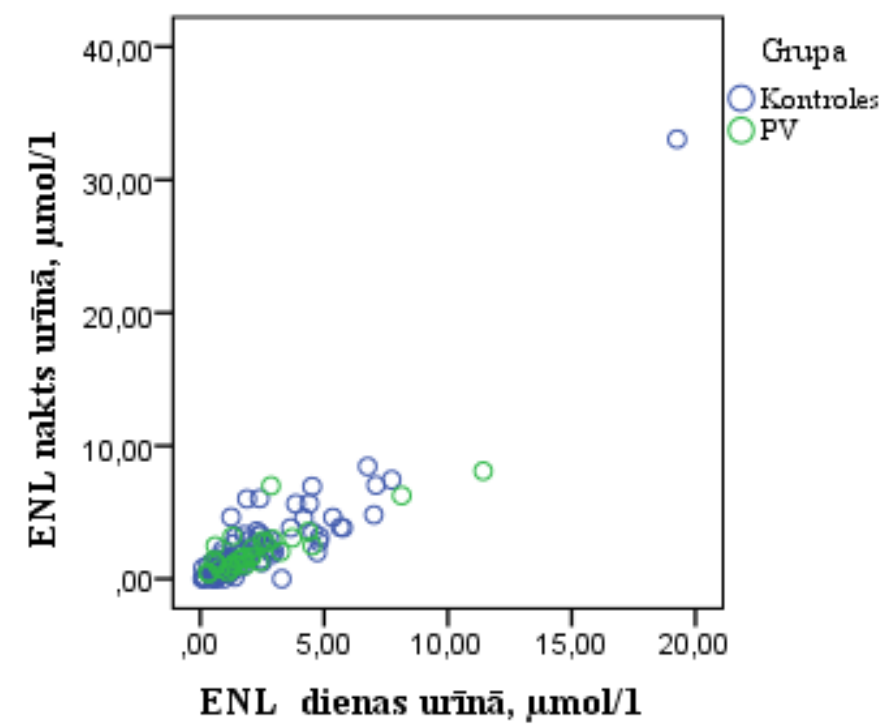

3.10. att. Korelācija Izmeklējumu grupā starp ENL koncentrāciju 12 h dienas urīnā un 12 h nakts urīnā PV un kontroles grupas dalībniekiem

ENL - enterolaktons ; PV - priekšdziedzera vēža pacientu grupa 
Netika atrasta statistiski nozīmīga atšķirība starp ENL koncentrāciju dienas un nakts urīnā ne PV grupā ( $p=0,131)$, ne kontroles grupā $(p=0,773)$.

Neviens no ENL izmeklējumiem (ENL 12 h dienas, 12 h nakts, 24 h urīnā un plazmā) nevienā grupā nekorelēja ar Glīsona skalas rādītājiem ( $>>0,05)$ PV grupā. PV grupā netika atrasta arī šo rādītāju korelācija ar PSA $(\mathrm{p}>0,05)$. Kontroles grupā tika konstatēta pozitīva korelācija starp PSA un ENL 12 h dienas urīnā $(r=0,301 ; p=0,005)$, ENL 12 h nakts urīnā $(r=0,406 ; p<0,001)$, ENL 24 h urīnā $(r=0,376 ; p<0,001)$ un ENL koncentrāciju plazmā $(r=0,255 ; p=0,015)$. Nevienā grupā netika atrasta korelācijas starp ENL koncentrāciju 12 h dienas, 12 h nakts, 24 h urīnā un plazmā un SHBG, LH, FSH, testosterona, 25(OH)D koncentrāciju, kā arī ar tauku, alkohola daudzumu uzturā un smēķěšanu (visur $\mathrm{p}>0,05$ ).

Abas pētījuma grupas tika sadalītas apakšgrupās - viena apaǩ̆grupa, kas lietojuši antibiotikas pēdējā gada laikā, un otra apakšgrupa, kas nebija lietojuši antibiotikas pēdējā gada laikā.

PV grupā 39,1\% (n=9) bija lietojuši un 60,9\% (n=14) nebija lietojuši antibiotikas pēdējā gada laikā. Kontroles grupā 25,3\% (n=21) bija un 74,7\% (n=62) nebija lietojuši antibiotikas pēdējā gada laikā. Atškirīibas starp pētījuma grupām antibiotiku lietošanas biežuma ziṇā nebija statistiski nozīmīgas $(p=0,202)$.

PV grupā nebija statistiski nozīmīgas atšķirības starp abām grupām, izvērtējot ENL koncentrāciju 12 h dienas, 12 h nakts, 24 h urīnā un plazmā (3.23. tab.).

3.23. tabula

Enterolaktona mediānā koncentrācija urīnā un plazmā PV pacientiem Izmeklējumu grupā atkarībā no antibiotiku lietošanas pēdējā gada laikā

\begin{tabular}{l|c|c|c}
\hline \multicolumn{1}{c|}{ Metabolīts } & $\begin{array}{c}\text { Ir lietojuši antibiotikas } \\
\text { pēdējā gada laikā }(\mathbf{n = 8 )}\end{array}$ & $\begin{array}{c}\text { Nav lietojuši antibiotikas } \\
\text { pēdējā gada laikā (n=14) }\end{array}$ & p \\
\hline ENL $\mu \mathrm{mol} / 12$ h dienas urīnā & $1,41(0,76 ; 7,23)$ & $1,94(1,50 ; 2,53)$ & 0,733 \\
ENL $\mu \mathrm{mol} / 12$ h nakts urīnā & $1,43(0,83 ; 4,37)$ & $1,59(1,06 ; 3,00)$ & 0,950 \\
ENL $\mu \mathrm{mol} / 24 \mathrm{~h}$ urīnā & $3,00(2,00 ; 10,70)$ & $3,65(2,84 ; 4,85)$ & 0,614 \\
ENL plazmā $(\mathrm{nmol} / \mathrm{L})$ & $29,23(9,53 ; 56,47)$ & $34,10(14,26 ; 50,80)$ & 0,705 \\
\hline
\end{tabular}

ENL - enterolaktons ; iekavās norādīta starpkvartiḷu amplitūda

Savukārt kontroles grupā ENL koncentrācija 12 h dienas, 12 h nakts, 24 h urīnā un plazmā bija statistiski ticami zemāka tiem, kas bija, nekā tiem, kuri nebija lietojuši antibiotikas pēdējā gada laikā (3.24. tab.). 
Enterolaktona koncentrācija urīnā un plazmā kontroles grupas dalībniekiem Izmeklējumu grupā atkarībā no antibiotiku lietošanas pēdējā gada laikā

\begin{tabular}{l|c|c|c}
\hline \multicolumn{1}{c|}{ Metabolīts } & $\begin{array}{c}\text { Ir lietojuši antibiotikas } \\
\text { pēdējā gada laikā } \\
(\mathbf{n = 2 1})\end{array}$ & $\begin{array}{c}\text { Nav lietojuši antibiotikas } \\
\text { pēdējā gada laikā (n=61) }\end{array}$ & p \\
\hline ENL $\mu \mathrm{mol} / 12$ h dienas urīnā & $0,95(0,56 ; 1,49)$ & $1,83(0,97 ; 3,38)$ & 0,020 \\
ENL $\mu \mathrm{mol} / 12$ h nakts urīnā & $0,90(0,39 ; 1,50)$ & $1,76(0,79 ; 3,45)$ & 0,032 \\
ENL $\mu \mathrm{mol} / 24 \mathrm{~h}$ urīnā & $2,11(0,86 ; 2,65)$ & $3,74(1,52 ; 7,10)$ & 0,023 \\
ENL plazmā $(\mathrm{nmol} / \mathrm{L})$ & $18,59(9,33 ; 26,41)$ & $29,29(16,25 ; 49,17)$ & 0,032 \\
\hline
\end{tabular}

ENL - enterolaktons ; iekavās norādīta starpkvartil̦u amplitūda

Uztura datu saistība ar ENL izmeklējumu rezultātiem arī šajā gadījumā tika analizēta divos veidos: atsevišksi tika analizēti 3 dienu vidējie dati un atsevišķi trešās uztura dienasgrāmatas rakstīšanas dienas dati.

Kontroles grupa: vidējie 3 dienu uztura dienasgrāmatas dati

Kontroles grupā netika atrastas korelācija starp ENL koncentrāciju 12 h dienas, $12 \mathrm{~h}$ nakts, $24 \mathrm{~h}$ urīnā un plazmā un maizes, rudzu maizes, maizes šksiedrvielu daudzumu uzturā $(\mathrm{p}>0,05)$. ENL koncentrācija $12 \mathrm{~h}$ dienas urīnā korelēja ar kopējo lignānu daudzumu uzturā $(r=0,215, \mathrm{p}=0,046)$ un maizes lignānu daudzumu $(\mathrm{r}=0,238$, $\mathrm{p}=0,027)$. ENL $24 \mathrm{~h}$ urīnā korelēja ar maizes lignānu daudzumu $(\mathrm{r}=0,226, \mathrm{p}=0,034)$. Sēklu maizes daudzums uzturā negatīvi korelēja ar ENL koncentrāciju plazmā (r=0,575, $\mathrm{p}=0,008)$, ENL koncentrāciju nakts urīnā $(\mathrm{r}=-0,499, \mathrm{p}=0,025)$ un ENL koncentrāciju 24 h urīnā $(r=-0,474, p=0,035)$.

$\underline{\text { Kontroles grupa: dati no trešās uztura dienasgrāmatas dienas }}$

Korelācija netika atrasta starp ENL koncentrāciju 12 h nakts, dienas, 24 h urīnā un plazmā ar maizes, rudzu maizes, sēklu maizes, šķiedrvielu, maizes šķiedrvielu un lignānu daudzumu uzturā ( $\mathrm{p}>0,05)$.

\section{PV grupa: vidējie 3 dienu uztura dienasgrāmatas dati}

PV grupā maizes daudzums uzturā korelēja ar ENL koncentrāciju plazmā $(\mathrm{r}=0,445 ; \mathrm{p}=0,0212), 12 \mathrm{~h}$ dienas urīnā $(\mathrm{r}=0,521, \mathrm{p}=0,003), 12$ h nakts urīnā $(\mathrm{r}=0,487$, $\mathrm{p}=0,005)$ un $24 \mathrm{~h}$ urīnā $(\mathrm{r}=0,550, \mathrm{p}=0,001)$. Sēklu maize uzturā korelēja ar ENL koncentrāciju 12 h nakts urīnā $(r=0,886, p=0,019)$ un 24 h urīnā $(r=0,886, p=0,019)$. Ar 
maizes šķiedrvielām korelēja ENL 12 h dienas ( $\mathrm{r}=0,419 ; \mathrm{p}=0,021)$, ENL 12 h nakts $(\mathrm{r}=0,424 ; \mathrm{p}=0,017)$ urīnā un ENL plazmā $(\mathrm{r}=0,348 ; \mathrm{p}=0,055)$. Netika atrasta statistiski ticama korelācija ENL plazmā ar ūdenī šķīstošām šķiedrvielām $(r=0,300 ; p=0,101)$, bet ar ūden̄̄ nešķīstošām šķiedrvielām korelācija bija statistiski ticama $(r=0,400 ; p=0,026)$. ENL koncentrācija plazmā, $12 \mathrm{~h}$ dienas, nakts un 24 h urīnā nekorelēja ar rudzu maizes, maizes lignānu un kopējo lignānu daudzumu uzturā.

PV grupa: dati no trešās uztura dienasgrāmatas dienas

Korelācijas atrastas PV apakšgrupā, kas nebija lietojuši antibiotikas pēdējā gada laikā: starp ENL koncentrāciju dienas urīnā un maizes $(\mathrm{r}=0,587, \mathrm{p}=0,027)$, rudzu maizes $(\mathrm{r}=0,736, \mathrm{p}=0,0100)$, maizes šķiedrvielu $(\mathrm{r}=0,538, \mathrm{p}=0,047)$, rudzu maizes šķiedrvielu $(\mathrm{r}=0,700, \mathrm{p}=0,016)$, kopējo lignānu $(\mathrm{r}=0,622, \mathrm{p}=0,018)$ un maizes lignānu daudzumu uzturā $(r=0,613, p=0,020)$. ENL koncentrācija plazmā korelēja ar rudzu maizes daudzumu uzturā $(\mathrm{r}=0,673, \mathrm{p}=0,023)$.

\subsection{Intervences pētījums ,Pilngraudu rudzu maizes ietekme uz priekšdziedzera vēža progresēšanu"}

Tika analizēti 37 PV pacientu dati. Pêtījuma dalībnieku vecums bija no 46 līdz 79 gadiem. Lielākā daḷa no pētījuma dalībniekiem dz̄ivoja Rīgā $(73,3 \%)$ vai Pierīgā (26,7\%). Pētījuma dalībnieku demogrāfiskais raksturojums atspoguḷots 3.25. tabulā.

3.25. tabula

Pētījuma dalībnieku demogrāfiskais raksturojums

\begin{tabular}{l|c|c|c|c}
\hline \multicolumn{1}{c|}{ Rādītājs } & Minimālais & Maksimālais & Vidējais & Standartnovirze \\
\hline Vecums, gadi & 46,0 & 79,0 & 64,5 & 7,9 \\
Augums, m & 1,54 & 1,87 & 1,7 & 0,1 \\
Ķ̧ermeņa masa, kg & 58,0 & 145,0 & 83,7 & 15,2 \\
Ķermeņa masas indekss $\left(\mathrm{kg} / \mathrm{m}^{2}\right)$ & 23,2 & 46,8 & 27,9 & 4,2 \\
\hline
\end{tabular}

Uzņemto uzturvielu daudzums ar maizi pirms analīžu veikšanas (1. posma 3. diena) atspoguḷots 3.26. tabulā. 
Uzturvielas PV pacientu uzturā no maizes 1. posmā 3. dienā (dati iegūti no uztura dienasgrāmatas)

\begin{tabular}{l|r|r|r|r|r|r|r}
\hline \multicolumn{1}{c|}{ Viela } & $\begin{array}{c}\text { Mini- } \\
\text { mums }\end{array}$ & $\begin{array}{c}\text { Maksi- } \\
\text { mums }\end{array}$ & $\begin{array}{c}\text { Vidē- } \\
\text { jais }\end{array}$ & $\begin{array}{c}\text { Stan- } \\
\text { dart- } \\
\text { novirze }\end{array}$ & $\begin{array}{c}\text { Medi- } \\
\text { ana }\end{array}$ & $\begin{array}{c}\text { I kvar- } \\
\text { tile }\end{array}$ & $\begin{array}{c}\text { III } \\
\text { kvartile }\end{array}$ \\
\hline Enerǵija, kcal & 48,0 & 1036,8 & 384,7 & 247,7 & 338,8 & 189,7 & 613,5 \\
Tauki, g/d & 0,3 & 4,7 & 2,0 & 1,3 & 1,6 & 1,0 & 3,4 \\
Olbaltumvielas, g/d & 1,5 & 28,7 & 11,3 & 7,2 & 9,6 & 5,5 & 18,0 \\
Ogḷhidrāti, g/d & 9,7 & 216,5 & 79,0 & 51,1 & 70,2 & 39,2 & 125,6 \\
Šķiedrvielas, g/d & 0,6 & 30,8 & 8,0 & 6,4 & 6,4 & 4,1 & 11,2 \\
Alkilrezorcīni, mg/d & 0,3 & 219,6 & 38,5 & 47,3 & 22,9 & 3,8 & 55,1 \\
Alkilrezorcīni 15:0 & 0,0 & 2,2 & 0,4 & 0,5 & 0,2 & 0,0 & 0,6 \\
Alkilrezorcīni 17:0 & 0,0 & 57,51 & 9,84 & 12,45 & 5,38 & 0,28 & 14,40 \\
Alkilrezorcīni 19:0 & 0,1 & 60,9 & 10,7 & 13,1 & 6,4 & 1,2 & 15,3 \\
Alkilrezorcīni 21:0 & 0,1 & 47,7 & 8,6 & 10,2 & 5,4 & 1,6 & 12,0 \\
Alkilrezorcīni 23:0 & 0,1 & 30,7 & 5,4 & 6,6 & 3,3 & 0,6 & 7,7 \\
Alkilrezorcīni 25:0 & 0,0 & 20,5 & 3,6 & 4,4 & 2,2 & 0,1 & 5,1 \\
Lignāni, $\mu$ g/d & 17,1 & 12582,0 & 1854,8 & 2820,3 & 839,4 & 237,1 & 1978,3 \\
Laricirezinols & 1,7 & 658,1 & 137,5 & 153,4 & 83,4 & 27,7 & 182,0 \\
Matairezinols & 0,0 & 50,8 & 10,4 & 12,8 & 5,4 & 1,4 & 14,4 \\
Mediorezinols & 0,7 & 220,3 & 42,9 & 47,8 & 28,9 & 9,5 & 55,6 \\
Sekoizolaricirezinols & 0,6 & 8825,1 & 768,6 & 2118,9 & 18,2 & 5,0 & 40,8 \\
Siringarezinols & 14,1 & 3599,5 & 675,7 & 766,5 & 459,8 & 144,3 & 910,5 \\
Pinorezinols & 0,0 & 1672,5 & 219,9 & 377,7 & 77,9 & 16,8 & 212,0 \\
\hline
\end{tabular}

3.27. tabulā atspoguḷots saņemto uzturvielu daudzums no maizes 3. posma 3. dienā (pēc 6 nedēḷas ilgas rudzu maizes lietošanas). Salīdzinot ar situāciju pirms rudzu maizes iekḷaušanas uzturā, ar rudzu maizi tiek uzņemts vairāk enerğijas, kā arī lielāks šķiedrvielu (mediānās vērtības pirms rudzu maizes iekḷaušanas uzturā: 6,4 g, pēc rudzu maizes lietošanas: 26 g) un uzṇemto AR un lignānu daudzums. 
3.27. tabula

Ar rudzu maizi uzṇemtās uzturvielas pētījuma 3. posma 3. dienā (no uztura dienasgrāmatām)

\begin{tabular}{l|r|r|r|r|r|r|r}
\hline \multicolumn{1}{c|}{ Viela } & $\begin{array}{c}\text { Mini- } \\
\text { mums }\end{array}$ & $\begin{array}{c}\text { Maksi- } \\
\text { mums }\end{array}$ & Vidējais & $\begin{array}{c}\text { Stan- } \\
\text { dart- } \\
\text { novirze }\end{array}$ & $\begin{array}{c}\text { Medi- } \\
\text { āna }\end{array}$ & $\begin{array}{c}\text { I kvar- } \\
\text { tile }\end{array}$ & $\begin{array}{c}\text { III } \\
\text { kvartile }\end{array}$ \\
\hline Enerǵija, kcal & 213,0 & 958,5 & 609,2 & 175,1 & 585,8 & 511,2 & 750,8 \\
Tauki, g/d & 1,3 & 5,7 & 3,6 & 1,0 & 3,5 & 3,0 & 4,5 \\
Olbaltumvielas, g/d & 7,0 & 31,3 & 19,9 & 5,7 & 19,1 & 16,7 & 24,5 \\
Oglhidrāti, g/d & 42,8 & 192,5 & 122,4 & 35,2 & 117,6 & 102,7 & 150,8 \\
Şkiedrvielas, g/d & 9,3 & 42,0 & 26,7 & 7,7 & 25,7 & 22,4 & 32,9 \\
Alkilrezorcīni, mg/d & 45,7 & 205,8 & 130,8 & 37,6 & 125,8 & 109,8 & 161,2 \\
Alkilrezorcīni 15:0 & 0,5 & 2,1 & 1,3 & 0,4 & 1,3 & 1,1 & 1,6 \\
Alkilrezorcīni 17:0 & 12 & 53,9 & 34,3 & 9,8 & 33 & 28,8 & 42,2 \\
Alkilrezorcīni19:0 & 12,7 & 57,1 & 36,3 & 10,4 & 34,9 & 30,5 & 44,8 \\
Alkilrezorcīni 21:0 & 9,9 & 44,7 & 28,4 & 8,2 & 27,3 & 23,9 & 35,1 \\
Alkilrezorcīni 23:0 & 6,4 & 28,7 & 18,3 & 5,2 & 17,6 & 15,3 & 22,5 \\
Alkilrezorcīni 25:0 & 4,3 & 19,2 & 12,2 & 3,5 & 11,7 & 10,2 & 15 \\
Lignāni, $\mu$ g/d & 1069,0 & 4811,0 & 3057,0 & 879,0 & 2940,0 & 2566,0 & 3768,0 \\
Laricirezinols & 137,0 & 617,0 & 392,0 & 113,0 & 377,0 & 329,0 & 483,0 \\
Matairezinols & 9,0 & 41,0 & 26,0 & 7,0 & 25,0 & 22,0 & 32,0 \\
Mediorezinols & 46,0 & 207,0 & 131,0 & 38,0 & 126,0 & 110,0 & 162,0 \\
Sekoizolaricirezinols & 15,0 & 68,0 & 43,0 & 12,0 & 42,0 & 36,0 & 54,0 \\
Siringarezinols & 750,0 & 3375,0 & 2145,0 & 616,0 & 2062,0 & 1800,0 & 2643,0 \\
Pinorezinols & 112,0 & 504,0 & 320,0 & 92,0 & 308,0 & 269,0 & 394,0 \\
\hline
\end{tabular}




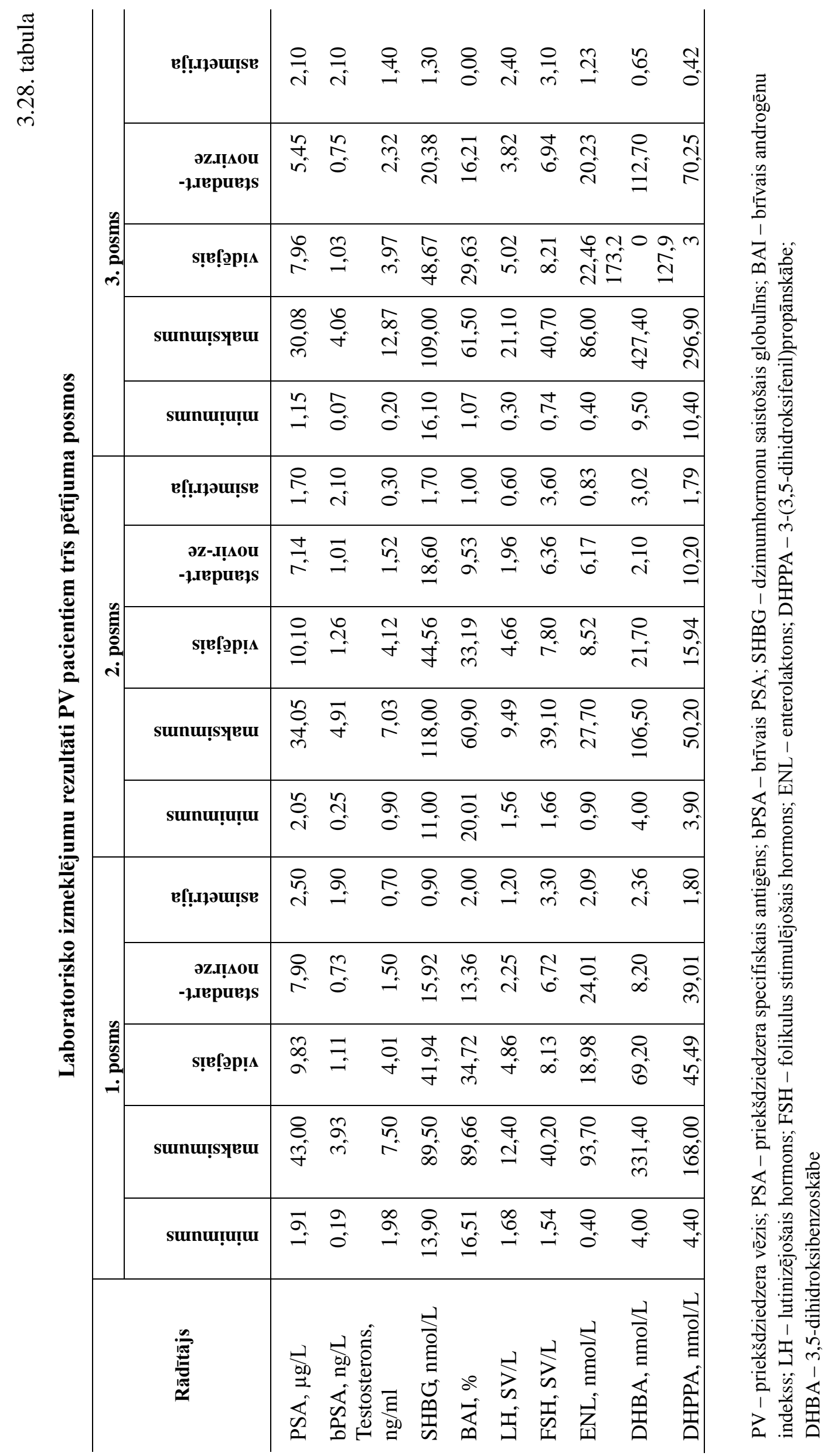


Pirmajā posmā AR metabolītu koncentrācija plazmā statistiski ticami neatšķīrās starp tiem, kas bija, un tiem, kas nebija lietojuši rudzu maizi uzturā iepriekšējā dienā pirms analīžu veikšanas $(\mathrm{p}=0,353 \div 0,775)$.

3.11. attēls rāda PSA izmaiņas trijos pētījuma posmos. PSA ir statistiski ticami zemāka koncentrācija 3. pētījuma posmā salīizinājumā ar 2. pētījuma posmu, mediānā vērtība attiecīgi $6,84(4,49 ; 9,80)$ un $8,05(5,21 ; 12,15) \mu \mathrm{g} / \mathrm{L}(\mathrm{p}=0,016)$. Novērojams arī PSA koncentrācijas amplitūdas (starpības starp lielāko un mazāko vērtību) samazinājums (3.11. attēls).

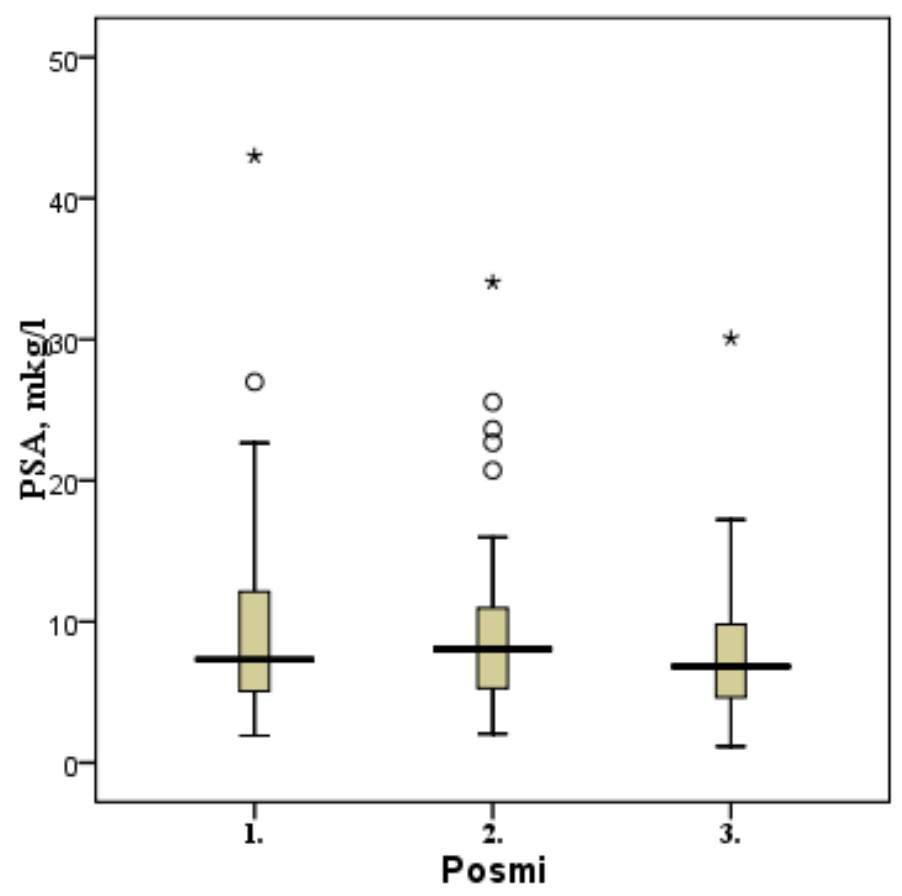

3.11. att. PSA izmaiṇas PV pacientiem trīs pētījuma posmos

Analizējot bPSA, testosterona, BAI, LH, FSH izmaiņas dažādos pētījuma posmos, netika konstatētas statistiski nozīmīgas izmaiņas starp pētījuma posmiem $(\mathrm{p}>0,05)$.

Izvērtējot SHBG izmaiņas pētījuma posmos, novēro mediānās vērtîbas palielināšanos 3. posmā attiecībā pret 2. posmu no 39,5 līdz 44,9 nmol/L ( $p=0,001)$ (3.12. attēls). 


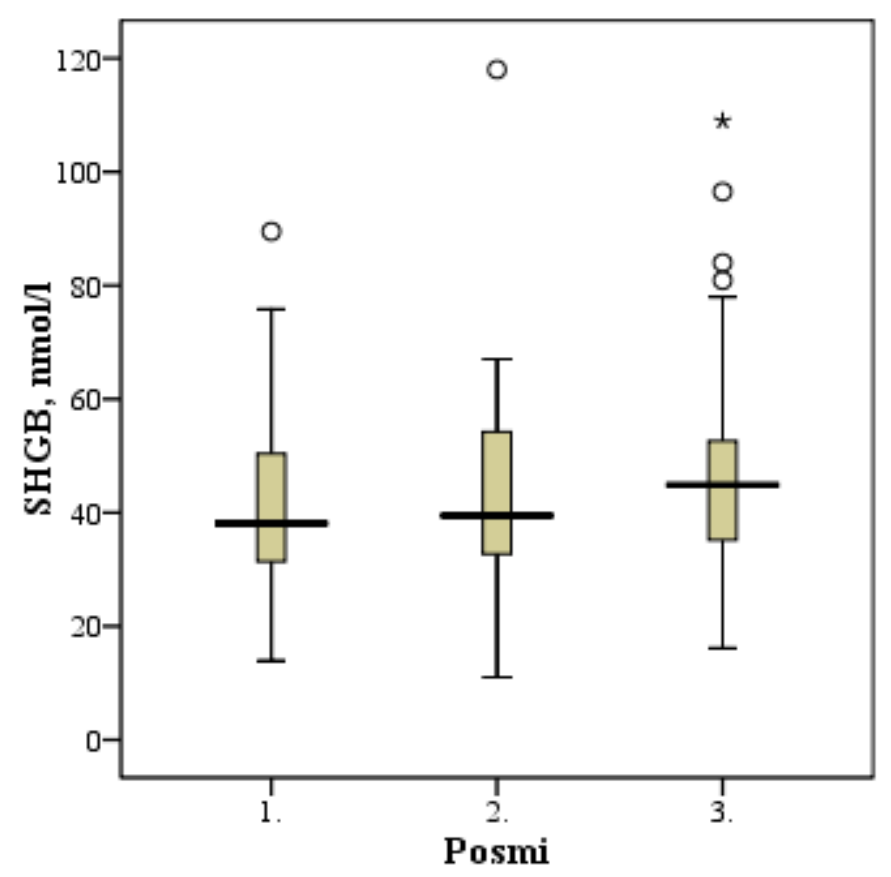

\subsection{2. att. SHBG izmaiṇas priekšdziedzera vēža pacientiem trīs pētījuma posmos}

Vērojama statistiski ticama mediānās enterolaktona koncentrācijas asins plazmā samazināšanās no $9,99(5,12 ; 28,08)$ nmol/L līdz 7,78 $(3,50 ; 13,91)$ nmol/L 2. posmā $(\mathrm{p}=0,002)$ un pieaugums 3. posmā līdz 16,92 $(5,26 ; 16,92) \mathrm{nmol} / \mathrm{L}(\mathrm{p}<0,001$, skat. 3.13 . att., vidējās vērtības skat. 3.28. tab.).

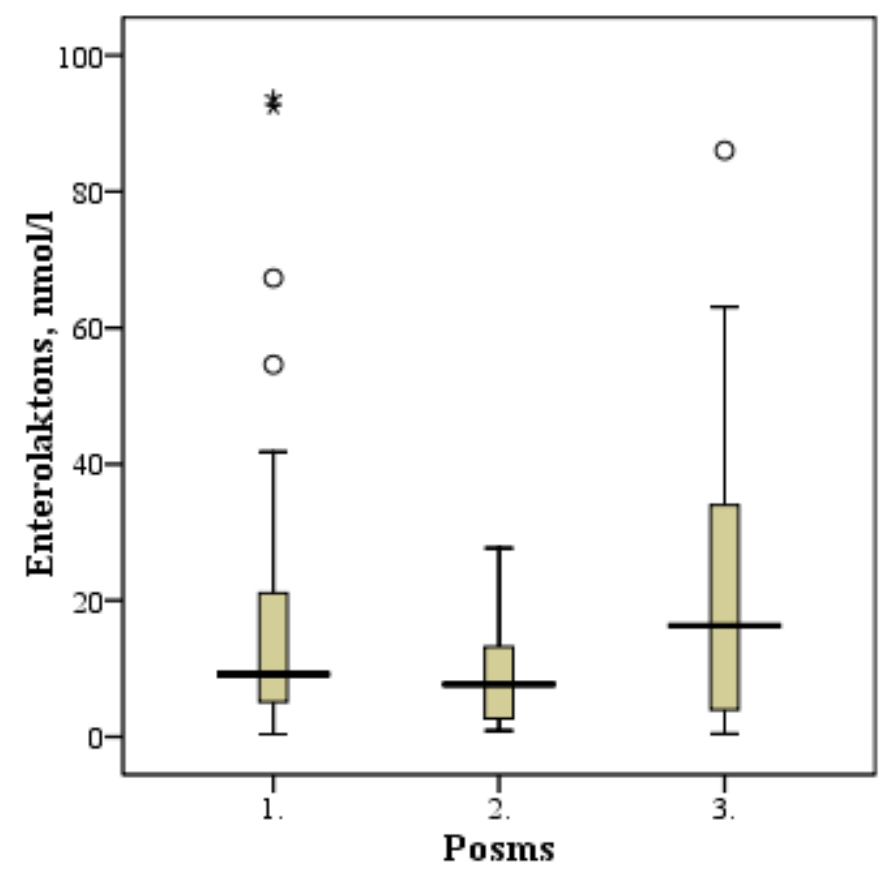

3.13. att. Enterolaktona izmaiņas priekšdziedzera vēža pacientiem trīs pētījuma posmos 
Atrasta statistiski ticama atšķirība DHBA koncentrācijai starp 1. un 2., starp 1. un 3. posmu, kā arī starp 2. un 3. posmu ( $<<0,001$, skat. 3.14. attēlu). DHBA mediānā koncentrācija: 1. posmā 36,50 (20,10; 85,63) nmol/L; 2. posmā 16,75 $(11,13 ; 22,55)$ nmol/L un 3. posmā 160,80 (83,70; 259,85) nmol/L (vidējās vērtības skat. 3.28. tabulā).

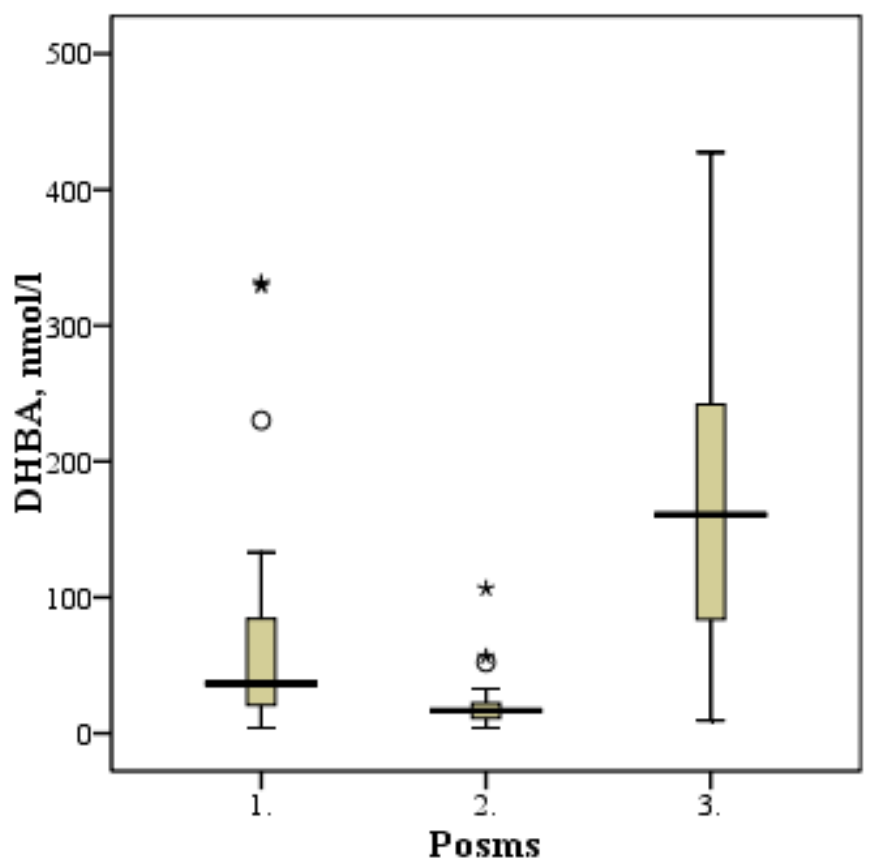

\subsection{4. att. DHBA koncentrācijas plazmā izmaiņas priekšdziedzera} vēža pacientiem trīs pētījuma posmos

Statistiski ticami atšķiras DHPPA koncentrācija starp 1. un 2., 3. posmu, kā arī starp 2. un 3. posmu ( $\mathrm{p}<0,001$, skat. 3.15. attēlu). DHBA mediānā koncentrācija: 1. posmā 33,25 $(21,78 ; 48,70)$ nmol/L; 2. posmā $13,40(9,50 ; 18,60)$ un 3. posmā 110,90 $(70,25 ; 184,10) \mathrm{nmol} / \mathrm{L}$ (vidējās vērtības skat. 3.28. tabulā). 


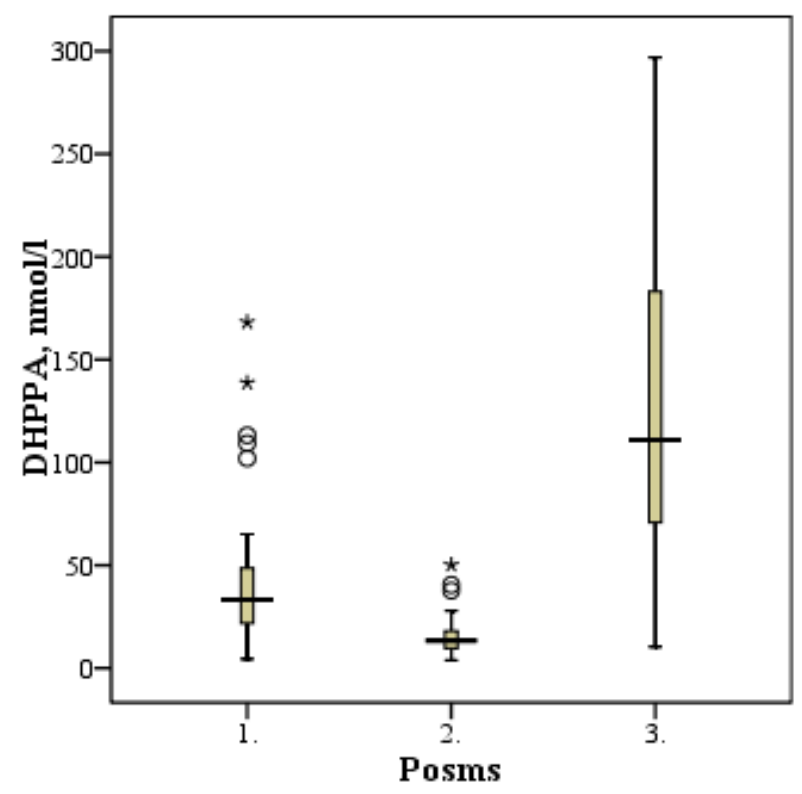

\subsection{5. att. DHPPA koncentrācijas plazmā izmaiṇas priekšdziedzera vēža pacientiem trīs pētījuma posmos}

Apoptozes aktivitāte tika analizēta 11 pacientu biopsijas un operācijas materiālos. Apoptozes aktivitāte operācijas materiālā 10 gadījumos bija lielāka nekā biopsiju materiālā, vienā gadījumā apoptozes aktivitātes skaiţ̦i (vidējais procentuālais pozitīvo šūnu daudzums) bija vienādi ar biopsijas materiālu. Apoptozes aktivitātes skaitḷi audzēja šūnās uzrādīja lielu izkliedi - 1-35\% un arī viena audzēja dažādos reǵionos apoptoze bija izteikta dažādās pakāpēs. Apoptozes skaitlıus skat. 3.29. tabulā.

3.29. tabula

Apoptozes aktivitāte priekšdziedzera biopsijas un operācijas materiālā

\begin{tabular}{c|c|c|c|c|c}
\hline $\begin{array}{c}\text { PV } \\
\text { pacients }\end{array}$ & $\begin{array}{c}\text { Glīsona skaitlis } \\
\text { priekšdziedzera } \\
\text { biopsijā }\end{array}$ & $\begin{array}{c}\text { Glīsona } \\
\text { skaitlis } \\
\text { operācijas } \\
\text { materiālā }\end{array}$ & $\begin{array}{c}\text { Audzēja tilpums } \\
\text { operācijas } \\
\text { materiālā (\% no } \\
\text { priekšdziedzera } \\
\text { tilpuma) }\end{array}$ & $\begin{array}{c}\text { Apoptozes } \\
\text { skaitlis } \\
\text { biopsijas } \\
\text { materiālā } \\
\text { (no- līdz) }\end{array}$ & $\begin{array}{c}\text { Apoptozes } \\
\text { skaitlis } \\
\text { operācijas } \\
\text { materiālā } \\
\text { (no- līdz) }\end{array}$ \\
\hline 1 & $3+4$ & $3+4$ & $5-10$ & $15-20$ & $20-25$ \\
2 & $3+4$ & $3+4$ & $16-20$ & $5-10$ & $10-15$ \\
3 & $3+3$ & $3+3$ & $8-10$ & $4-8$ & $8-12$ \\
4 & $2+2$ & $3+3$ & $15-17$ & $1-2$ & $6-10$ \\
5 & $3+4$ & $3+3$ & 15 & $20-25$ & $20-25$ \\
6 & $3+3$ & $4+4$ & $12-15$ & 20 & 30 \\
7 & $3+3$ & $3+3$ & $10-12$ & $5-10$ & $10-15$ \\
8 & $3+3$ & $2+2$ & $1-2$ & $1-2$ & $5-10$ \\
9 & $3+3$ & $3+4$ & $20-25$ & 10 & $30-35$ \\
10 & $3+2$ & $3+4$ & $60-70$ & $5-10$ & $30-35$ \\
11 & $3+3$ & $3+4$ & $5-8$ & $10-15$ & 30 \\
\hline
\end{tabular}


Izvērtēt apoptozes izmaiņu saistību ar diētas pārmaiņām apgrūtina fakts, ka apoptozes aktivitāti ietekmē audzēja diferenciācijas pakāpe - jo audzējs ir ar augstāku Glīsona skaitli, jo augstāka apoptozes aktivitāte. Piemēram, Glīsona 4. komponents uzrādīja maksimāli 35\%, bet Glīsona 2. komponents uzrādīja 1-2\%. Arī vienādas diferenciācijas audos tika konstatēta visai liela rādītāju izkliede (Glīsona 4. komp. divos gadījumos bija ar 12 un 35\%). Glīsona skaitlis 6 gadījumos bija atšķirīgs no konstatētā operācijas materiālā: 5 gadījumos operācijas materiālos Glīsona skaitlis bija augstāks par biopsijās konstatēto, vienā gadījumā bija zemāks, šajā gadījumā apoptozes aktivitāte arī bija augstāka, lai gan audzējs bija labāk diferencēts. Lai gan lielās izkliedes un mazā pētījuma dalībnieku skaita dēḷ nevarēja iegūt statistiski ticamus rezultātus, tomēr var secināt, ka rudzu maizei, iespējams, ir PV progresēšanu kavējoša iedarbība. Par to liecina apoptozes palielināšanās 10 no 11 operācijas materiāliem, tātad rudzu maizes lietošanas rezultātā tika konstatēta tendence pieaugt apoptozes aktivitātei.

\subsection{D vitamīns}

D vitamīna koncentrācija serumā tika noteikta 33 PV pacientiem un 153 kontroles grupas vīriešiem gadījumu kontroles pētījumā. Pētījumā dalībnieku vidējais vecums bija 59,6 (SD 8,6) gadi. Vidējais ĶMI bija 28,1 (SD 3,8) kg/m². Palielināts svars vai aptaukošanās bija 77\% (n=143) pētījuma dalībnieku. Netika atrastas statistiski ticamas atšķirības kontroles un vēža grupā attiecībā uz tādiem parametriem kā ĶMI, smēķēšana, augums un dzīvesvieta (3.30. tabula).

3.30. tabula

Priekšdziedzera vēža un kontroles grupas raksturojums D vitamīna pētījumā

\begin{tabular}{|c|c|c|c|}
\hline Pētījuma dalībnieku raksturojums & $\begin{array}{c}\text { Kontroles grupa } \\
n=153\end{array}$ & $\underset{n=33}{P V}$ & $\mathbf{p}$ \\
\hline \multicolumn{4}{|l|}{ Vecums, gadi, n (\%) } \\
\hline $45-55$ & $59(38,6 \%)$ & $3(9,1 \%)$ & \\
\hline $55-65$ & $59(38,6 \%)$ & $11(33,3 \%)$ & $<0,001$ \\
\hline$>65$ & $35(22,8 \%)$ & $19(57,6 \%)$ & \\
\hline Vidējais & $58,1(8,4)$ & $65,0(7,3)$ & $<0,001$ \\
\hline \multicolumn{4}{|l|}{ Ķermena masas indekss, $\mathrm{kg} / \mathrm{m}^{2}, \mathrm{n}(\%)$} \\
\hline$<25,0$ (normāls) & $36(23,5 \%)$ & $7(21,2 \%)$ & 0,777 \\
\hline$\geq 25,0$ (palielināts svars) & $117(76,5 \%)$ & $26(78,8 \%)$ & \\
\hline Augums, m (SD) & $1,77(0,06)$ & $1,77(0,07)$ & 0,877 \\
\hline
\end{tabular}


3.30. tabulas turpinājums

\begin{tabular}{|c|c|c|c|}
\hline Pētījuma dalībnieku raksturojums & Kontroles grupa & PV grupa & $\mathbf{p}$ \\
\hline \multicolumn{3}{|l|}{ Dzīvesvieta } & \multirow{3}{*}{1,000} \\
\hline Pilsēta & $145(94,8 \%)$ & $31(93,9 \%)$ & \\
\hline Lauki & $8(5,2 \%)$ & $2(6,1 \%)$ & \\
\hline \multicolumn{3}{|l|}{ Izglītība } & \multirow{5}{*}{0,030} \\
\hline Pamatizglītība & $7(4,6 \%)$ & $3(9,0 \%)$ & \\
\hline Vidējā & $53(34,6 \%)$ & $5(15,2 \%)$ & \\
\hline Koledžas & $60(39,2 \%)$ & $11(33,3 \%)$ & \\
\hline Augstākā & $33(21,6 \%)$ & $14(42,5 \%)$ & \\
\hline \multicolumn{3}{|l|}{ Smēḳēšana } & \multirow{4}{*}{0,542} \\
\hline Nesmēksē & $86(56,2 \%)$ & $22(66,7 \%)$ & \\
\hline Bijušais smēḳētājs & $19(12,4 \%)$ & $3(9,1 \%)$ & \\
\hline Smēksē & $48(31,4 \%)$ & $8(24,2 \%)$ & \\
\hline \multicolumn{3}{|l|}{ Pastaigas vai riteņbraukšana } & \multirow{3}{*}{0,007} \\
\hline$<1$ h dienā & $122(79,7 \%)$ & $19(57,6 \%)$ & \\
\hline$\geq 1 \mathrm{~h}$ dienā & $31(20,3 \%)$ & $14(42.4 \%)$ & \\
\hline
\end{tabular}

D vitamīna daudzums uzturā tika analizēts 22 PV un 128 kontroles grupas dalībniekiem. Ar uzturu uzņemtais D vitamīna daudzums PV grupā vidēji bija 286 (SD 347) SV no 27 līdz 1846 SV, kontroles grupā 244 (SD 171) SV no 31 līdz 935 SV. D vitamīna daudzums uzturā abās grupās neatšķīīās $(\mathrm{p}=0,096)$. Tikai 5\% $(\mathrm{n}=8)$ no 150 pētījuma dalībniekiem ar uzturu uzņēma nepieciešamo $\mathrm{D}$ vitamīna daudzumu. Galvenais D vitamīna uztura avots abās pētījuma grupās bija zivis (82\% PV grupā un 77\% kontroles grupā). Citi D vitamīna uztura avoti bija piena produkti (7\% PV grupā un $8 \%$ kontroles grupā), olas (6\% PV grupā un 8\% kontroles grupā) un aknas (2\% PV grupā un 3\% kontroles grupā). Zivju, piena produktu un olu daudzums uzturā starp abām grupām neatšksīrās $(0,578<\mathrm{p}>0,141)$. D vitamīna daudzums uzturā nekorelēja ne ar kopējo, ne ar piesātināto tauku daudzumu $(\mathrm{p}>0,05)$.

D vitamīna deficīts bija 55\% (n=18) PV grupā un 70\% (n=107) kontroles grupā. D vitamīna nepietiekamība bija 30\% $(n=10)$ PV grupā un 23\% $(n=35)$ kontroles grupā. Normāls D vitamīna līmenis bija 15\% $(n=5)$ PV grupā un 7\% $(n=11)$ kontroles grupā. PV grupā mediānā seruma 25(OH)D koncentrācija $18,3(13,5 ; 25,5) \mathrm{ng} / \mathrm{mL}$ bija statistiski ticami lielāka nekā 15,2 $(15,2 ; 21,8) \mathrm{ng} / \mathrm{mL}$ kontroles grupas vīriešiem ( $p=0,017$; skat. 3.16. attēlu). 


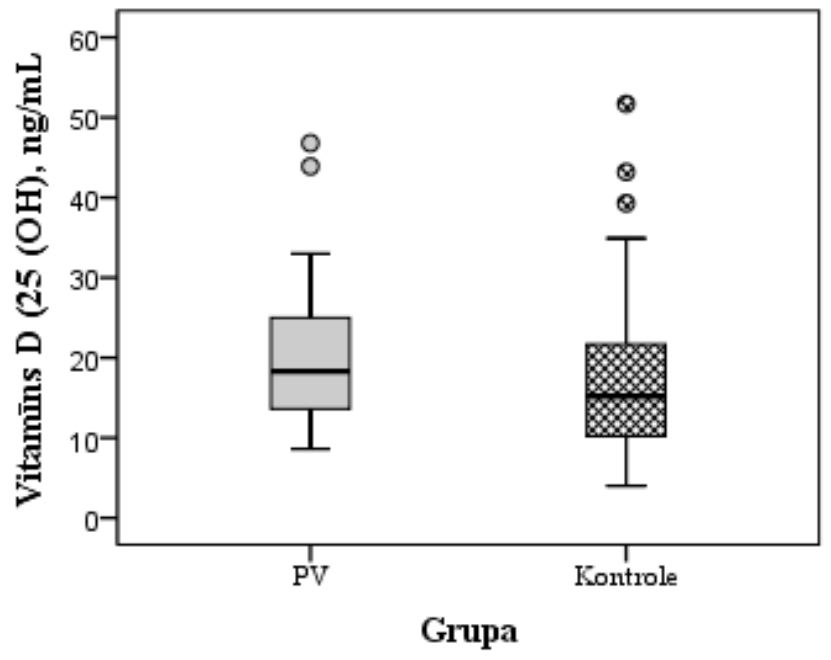

\subsection{6. att. Mediānā D vitamīna koncentrācija PV un kontroles grupas vīriešiem}

Tika konstatēta tendence, ka D vitamīna koncentrācija serumā PV grupā bija augstāka vasarā un ruden̄̄ nekā ziemā un pavasarī, savukārt kontroles grupā D vitamīna koncentrācija serumā zemāka bija tikai pavasarī. Tomēr minētās D vitamīna seruma koncentrācijas sezonālās atšķirības abās grupās nebija statistiski ticamas (skat. 3.17. attēlu).

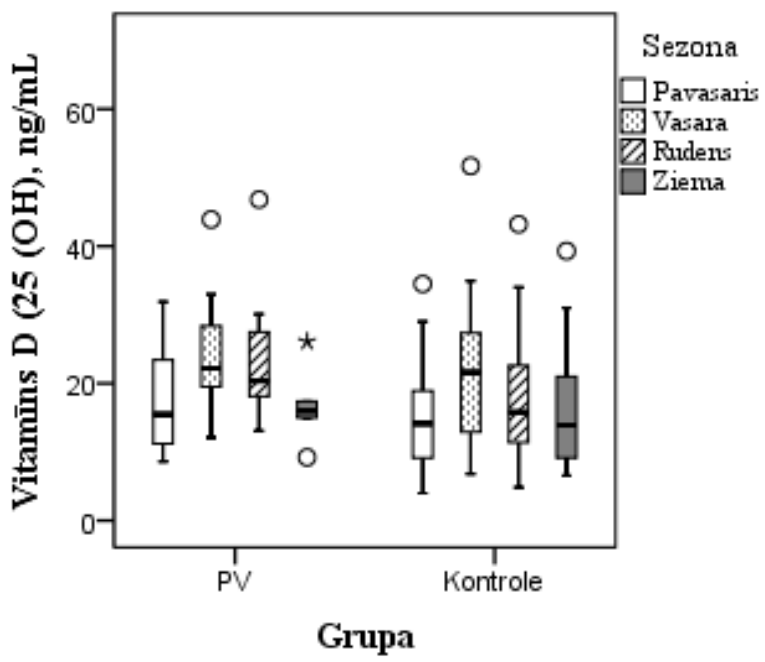

\subsection{7. att. Mediānā D vitamīna koncentrācija serumā dažādās sezonās PV un kontroles grupas vīriešiem}

PV grupas pacienti vairāk laika pavadīja pastaigās vai braucot ar riteni (3.30. tabula), un vērojama pieaugoša tendence mediānā D vitamīna koncentrācijai asinīs $(18,1(13,3 ; 22,3) \mathrm{ng} / \mathrm{mL}$ un $24,4(14,1 ; 28,1) \mathrm{ng} / \mathrm{mL})$ saistībā ar fiziskām aktivitātēm, kontroles grupā to neatrod (3.18. attēls). 


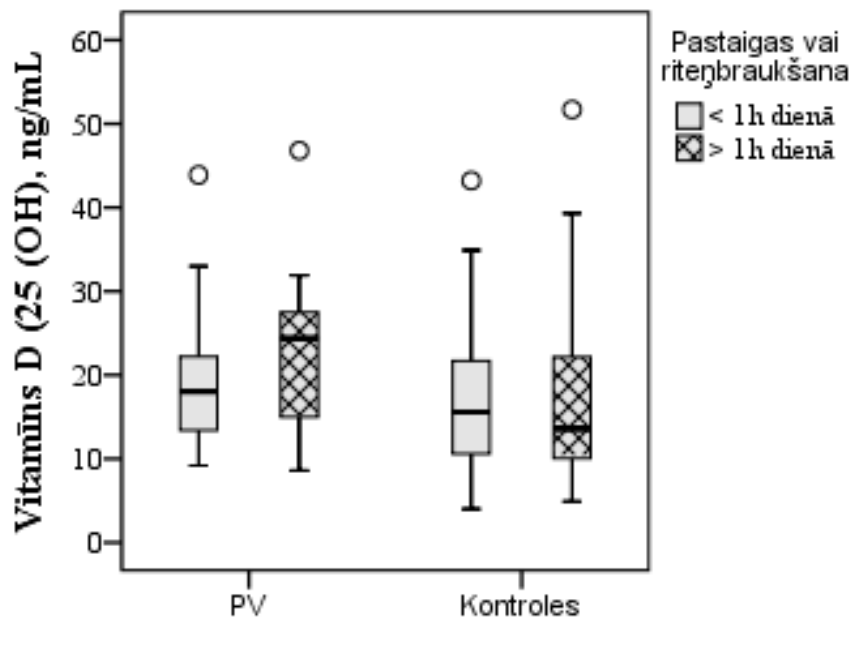

Grupa

\subsection{8. att. Mediānā D vitamīna koncentrācija saistībā ar fizisko aktivitāti PV un kontroles grupas vīriešiem}

Starp D vitamīna koncentrāciju serumā un D vitamīna daudzumu uzturā atrasta pozitīva korelācija kontroles grupā $(\mathrm{r}=0,363$; $\mathrm{p}<0,001)$, bet nav atrasta PV grupā ( $\mathrm{r}=-$ 0,103; $\mathrm{p}=0,630)$. Arī korelācija starp $\mathrm{D}$ vitamīna seruma koncentrāciju un vecumu tika konstatēta kontroles grupā $(r=0,209 ; p=0,023)$, bet ne PV grupā $(r=0,176 ; p=0,411)$, skat. 3.19. attēlu.

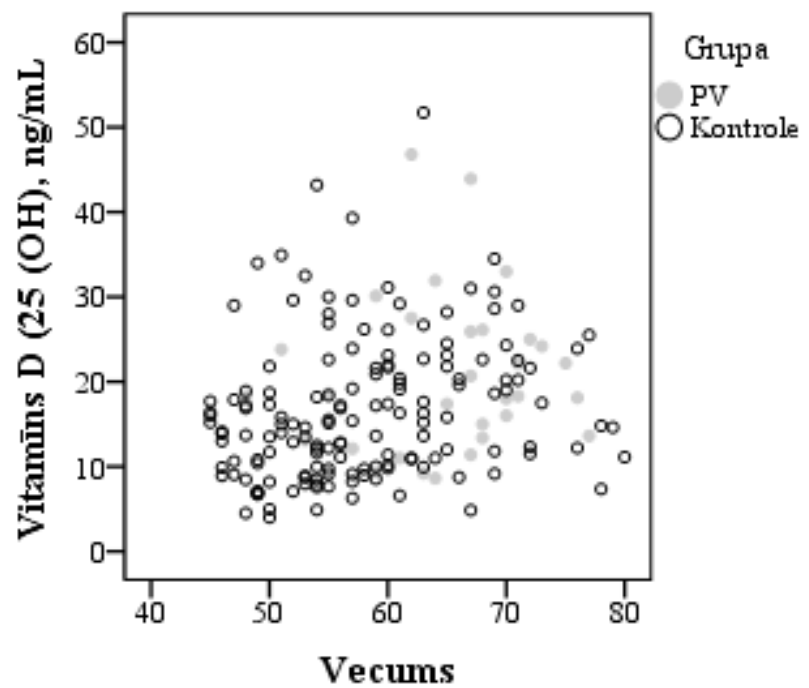

\subsection{9. att. D vitamīna koncentrācija un vecuma korelācija PV un kontroles grupas vīriešiem}

Nevienā grupā netika atrasta statistiski nozīmīga korelācija starp D vitamīna līmeni serumā un ĶMI (kontroles grupā r=0,042; $p=0,650$; PV grupā r=-0,288; $p=0,173$ ) un PV grupā - ar Glīsona skaitli (r=-0,092; p=0,677). D vitamīna koncentrācija serumā 
korelēja ar PSA kontroles grupā $(r=0,363 ; \mathrm{p}<0,001)$, bet ne PV grupā $(r=-0,103$; $\mathrm{p}=0,630)$. PV grupā tika konstatēta korelācija starp D vitamīna koncentrāciju serumā un SHBG $(r=0,430 ; p=0,041)$, bet netika konstatēta kontroles grupā $(r=0,037 ; p=0,761)$. Nevienā grupā netika atrasta statistiski nozīmīga korelācija starp D vitamīna līmeni serumā un testosteronu (kontroles grupā $r=0,106 ; p=0,381 ; P V$ grupā $r=0,081 ; p=0,713$ ), kā arī ar kalcija daudzumu uzturā (kontroles grupā $\mathrm{r}=-0,092 ; \mathrm{p}=0,320 ; \mathrm{PV}$ grupā $\mathrm{r}=-0,058 ; \mathrm{p}=0,787)$. 


\section{DISKUSIJA}

\subsection{Alkilrezorcīni un lignāni Latvijas maizē}

N̦emot vērā maizes lielo nozīmi Latvijas iedzīvotāju uzturā, svarīgi zināt biolog̣iski aktīvo vielu daudzumu dažādos Latvijas maizes veidos. Zinot AR daudzumu Latvijas maizes veidos, var daudz labāk spriest par pilngraudu produktu daudzumu uzturā, ko precīzi izvērtēt ir grūti gan maizes patērētājam, gan zinātniekiem.

Vislielākais AR daudzums bija konstatēts rudzu maizē $(\sim 560-840 \mu \mathrm{g} / \mathrm{sausnā})$, mazāks - saldskābmaizē (jauktu rudzu un kviešu miltu maizē) ( 200-330 $\mu \mathrm{g} / \mathrm{sausnā})$, un viszemākais AR daudzums bija rafinēto kviešu miltu maizē ( 25-31 $\mu \mathrm{g} / \mathrm{sausnā})$. Tā kā AR lokalizēti grauda ārējā apvalkā un tos uzskata par pilngraudu marķieriem [Chen, 2004; Ross, 2004], uztura vadlīnijās visā pasaulē, ieskaitot Latvijas Veselības ministriju [Veselības ministrija 2008], Somijas Uztura rekomendācijas [Finnish Nutrition Recommendations, National Nutrition Council 2005], ASV Lauksaimniecības departamentu [United States Department of Agriculture, 2010] un Lielbritānijas Uztura aǵentūru [UK Food Standards Agency, 2007], iesaka lietot pilngraudu produktus. Šajās rekomendācijās norādīts, ka vismaz pusei no visiem graudaugu produktiem jābūt pilngraudu produktiem un dienā jāuzṇem vismaz trīs porcijas pilngraudu produktu, jo graudaugu protektīvā iedarbība saistīta tieši ar pilngraudu produktu daudzumu uzturā un protektīvās vielas pilngraudos, tostarp lignāni, citi fenola savienojumi, augu stanoli un stiroli, E vitamīns, folāti un minerālvielas, atrodas grauda apvalka dạ̧āa [Slavin, 2004].

Tomēr pilngraudu produktu daudzums uzturā ir nepietiekams, īpaši ASV un Lielbritānijā [Lang 2003; Slavin, 2004]. Skandināvu uzturā ir vairāk pilngraudu produktu, īpaši Somijā, tas saistīts ar rudzu maizes lietošanu uzturā [Lang, 2003]. Latvijā, iespējams, rudzu maizi lieto vēl vairāk [Nordic Council of Ministers 2003, FAOSTAT 2007], bet salīdzināšanu apgrūtina atšķirīgu metožu (piem., uztura biežuma aptaujas anketas, uztura dienasgrāmatas, produktu patēriņa dati) lietošana dažādās valstīs.

Rafinēšanas process miltu ražošanas laikā ievērojami samazina šo biologiiski aktīvo vielu daudzumu. Saskaņā ar ASV Pārtikas un zāḷu pārvaldes (FDA - Food and Drug Administration) definīciju pilngraudu miltiem jāsatur visas grauda daḷas (dīglis, endosperma un apvalks jeb klija) tādās pašās proporcijās kā graudā un pilngraudu maizei jāsatur vismaz 51\% pilngraudu miltu [U.S. Food and Drug Administration 
2006]. Reprezentatīva Eiropas graudaugu biologiski aktīvo vielu protektīvās iedarbības pētījuma projekta ekspertu grupa 2010. gadā definēja, ka pilngraudiem jāsatur visas grauda daḷas tādās pašās proporcijās kā graudā, kā arī apraksta pieḷaujamās tehnologiskās darbības, piemēram, kliju pievienošanu rafinētu miltu produktiem [Healthgrain Consortium, 2010]. Tomēr Eiropas valstīs nav vienotas nostājas, cik daudz pilngraudu jāsatur produktam, lai to varētu saukt par pilngraudu produktu. Latvijā rūpnieciski ražotā maize, tātad maize, ko lieto lielākā populācijas daļa, nesatur pilngraudu miltus. Maizes milti Latvijā nesatur grauda dīgḷa daḷu, un kliju daḷa kviešu maizei tiek pievienota atsevišķi. Tikai daži mazie ražotāji Latvijā lieto pilngraudu rudzu un kviešu miltus. Lielie maizes ražotāji izvairās lietot pilngraudu miltus maizes ražošanā, jo tiem ir īsāks derīguma termiņš, un tas palielina maizes cenu. Ražotāji uzskata, ka sekmīgu pilngraudu maizes pārdošanu var ierobežot arī tas, ka pilngraudu maizes struktūra nav tik mīksta, un patērētājs, kas nav pieradis lietot šādu maizi, to varētu nepirkt. No komerciāli ražotiem pilngraudu maizes veidiem plaši pieejamas ir vien̄̄gi importētās sausmaizītes (crisp bread). Tikai 2013. gada otrajā pusē, kad pētījums jau bija pabeigts, Latvijas veikalos kḷuva pieejama komerciāli ražota maize, kas satur arī pilngraudu miltus. Tajā pašā laikā maize no pilngraudu miltiem ir plaši pieejama lielākajā daļā Eiropas valstu, ieskaitot Somiju, Zviedriju, Dāniju, Vāciju. Kaut arī Latvijas maizes veidus nevar uzskatīt par pilngraudu maizi, tomēr AR daudzums Latvijas rudzu maizē [Meija, 2013a] ir līdzīgs kā Somijas [Mattila, 2005], Zviedrijas [Ross, 2003a] un Polijas [Kulawinek, 2008] pilngraudu rudzu maizē. Tas liecina par to, ka rudzu graudu ražošanas procesā visās valstīs tiek noṇemta līdzīgi maza grauda apvalka daḷa. Savukārt atšķirīga situācija ir ar saldskābmaizi. AR daudzums saldskābmaizē (jauktu rudzu un kviešu miltu maizē) bija ievērojami mazāks. Tas ir izskaidrojams ar to, ka rudzu milti, ko izmanto saldskābmaizes ražošanā, ir bīdelēti, bieži tiek lietoti arī bīdelēti kviešu milti. Kopumā jāuzsver, ka jauktu miltu (kviešu un rudzu miltu) maizē, analizējot Latvijas un Somijas maizi, AR daudzums variē plašās robežās $(200-707 \mu \mathrm{g} / \mathrm{g})$, turklāt Latvijas maizē tas ir zemāks. Lielākā daļa Latvijas rudzu maizes veidu satur arī nelielus daudzumus pievienoto kviešu miltu.

Liela daļa Latvijas maizes veidu tiek nosauktas par graudu vai sēklu maizi, un patērētājam rodas priekšstats, ka tā ir pilngraudu maize, kaut patiesībā tā ir rafinēto kviešu miltu maize, kam nedaudz pievienotas sēklas vai klijas un tumšo krāsu piešķir iesala ekstrakts. Šāda veida maizi nevar uzskatīt par pilngraudu maizi. N̦emot vērā to, ka Latvijā maizes ražošanā izmanto tikai rafinētos kviešu miltus, tad kviešu maizē AR 
daudzums ir atkarīgs no pievienoto kliju daudzuma. Daļa pētījumu rāda, ka kviešu klijas satur mazāk AR nekā rudzu klijas [Chen, 2004; Mattila 2005; Kamal-Eldin, 2009], citi pētījumi sniedz pretējus rezultātus [Kulawinek 2008; Andersson, 2010]. Tas skaidrojams ar tehnoloǵiskām atšķirībām kliju ražošanā. Latvijas maizē norādīts zemāks šķiedrvielu daudzums nekā Somijas maizē. Skaidrojums varētu būt tāds, ka Latvijā šķiedrvielas maizē netiek noteiktas, to daudzumu izrēķina atkarībā no miltu un pievienoto produktu sastāva.

Baltmaizē AR daudzums, kā jau gaidāms, bija vismazākais, jo tās ražošanā izmantoti rafinētie kviešu milti, kas gandrīz nemaz nesatur grauda klijas dalıu.

N̦emot vērā to, ka pilngraudu milti maizes ražošanā Latvijā gandrīz netiek lietoti, AR var uzskatīt par kliju vai maizes šķiedrvielu marķieri, nevis pilngraudu marķieri.

Mūsu rezultāti, vērtējot AR homologu attiecību Latvijas maizē, saskanēja ar iepriekšējiem rezultātiem [Mattila, 2005; Kulawinek, 2008]. C17:0/C21:0 rudzu maizē bija $0,3-1,3$, saldskābmaizē (jauktu miltu maizē) $0,1-0,2$ un baltmaizē (rafinēto kviešu miltu maizē) $1,1-1,3$.

Lai AR varētu izmantot par marķieri kliju daudzuma saturam maizēe, ir svarīgi noteikt AR daudzumu dažādos rudzu un kviešu produktos dažādās valstīs, jo to daudzums ir atkarīgs gan no augu bioloğiskās daudzveidības, gan no pārtikas ražošanas tehnologijas īpatnībām [Chen, 2004]. Valstīs, kur izmanto pilngraudu miltus, AR raksturo pilngraudu miltu daudzumu maizē vai citos produktos, savukārt Latvijas maizes veidos AR pārsvarā atspoguḷo kliju daudzumu maizē, kas līdz ar to norāda uz maizes šķiedrvielu daudzumu, nevis pilngraudu miltu daudzumu.

Kopsavilkumā - AR daudzums dažādās valstīs ir līdzīgs rudzu un kviešu maizē, bet lielas atšķirīibas ir jaukto kviešu un rudzu miltu maizē. Nav obligātas prasības norādīt katra miltu veida procentuālo saturu, tāpēc patērētājam ir problemātiski izvērtēt, cik daudz graudu kliju daļu satur attiecīgā maize. AR daudzumu maizē var izmantot kā kliju vai šķiedrvielu daudzuma marķieri, bet ne pilngraudu satura marķieri, jo ne visas valstis maizes cepšanā lieto pilngraudu miltus. Augstāka AR koncentrācija maizē norāda uz lielāku protektīvās iedarbības potenciālu.

Analizējot lignānu daudzumu, tas visaugstākais bija kviešu maizē ar sēklām ( 9000-10 $000 \mu \mathrm{g} / 100 \mathrm{~g})$. Augsto lignānu koncentrāciju noteica pievienoto sēklu, visvairāk - linsēklu, daudzums. Somijas sēklu maizē salīdzinoši bija zemāks lignānu daudzums $(\sim 3800 \mu \mathrm{g} / 100 \mathrm{~g})$. Arī rudzu maizē bija augsts lignānu saturs (800-1100 
$\mu \mathrm{g} / 100 \mathrm{~g})$. Somijas rudzu maizē lignānu daudzums bija lielāks (1000-1400 $\mu \mathrm{g} / 100 \mathrm{~g}$ ), jo Somijas rudzu maizes ražošanā izmantoti pilngraudu rudzu milti, kuros ir augstāks lignānu saturs. Viszemākais lignānu daudzums bija baltmaizē $(90-100 \mu \mathrm{g} / 100 \mathrm{~g})$. Rezultāti rāda, ka lignānu daudzums Latvijas sēklu un rudzu maizē ir līdzvērtīgs vai pat augstāks nekā Somijas maizē [Meija, 2013b], līdz ar to maize var būt nozīmīgs lignānu avots uzturā.

\subsection{Pētījuma dalībnieku uzṇemtā uztura raksturojums}

Pētījuma grupas. PV un kontroles grupas dalībniekiem neatšķīās tādi parametri kā vidējais ĶMI, smēķēěsana, fiziskā aktivitāte, onkoloǵiskās slimības anamnēzē, antibiotiku lietošana pēdējā gada laikā, seksuālā aktivitāte dzīves laikā. Abām grupām atšķīās vidējais vecums (PV pacientu vecums bija lielāks nekā kontroles grupas dalībnieku vecums). Uzṇemtās energijas daudzums negatīvi korelēja ar vecumu. Pēc samērošanas pēc uzņemtās energijijas daudzuma tika statistiski novērsta vecuma atšksirība starp grupām. Analizējot uzņemto uzturu, pētîjuma dalībnieki arī tika sadalīti divās vecuma grupās: līdz un pēc 60 gadiem, jo 60 gadi ir robeža, kad mainās enerğētiskās vajadzības [Willet, 2013]. N̦emot vērā minētās datu analīzes metodes, abās pētījuma grupās (arī sadalot pēc vecuma grupām) nebija atšķirību ne uzņemto uzturvielu daudzuma ziṇā (olbaltumvielas, tauki, og̣̦hidrāti, šķīstošās, nešķīstošās, kopējās šķiedrvielas), ne arī produktu grupu (graudaugi, gal̦a, gaļas produkti, piena produkti, dārzeņi, augḷi un ogas), ne arī atsevišķku produktu (tomāti, kāposti, ķiploki, rieksti, kafija, tēja) daudzumā uzturā. Mūsu pētījuma rezultāti nav pretrunā ar iepriekš veiktajiem, jo, kaut arī daļa pētījumu norāda uz atsevišķরu produktu vai uzturvielu iespējamo protektīvo lomu, citi to neapstiprina [Kristal, 2010; Schmid, 2011].

Abu pētījuma grupu uzturā neatšķīrās arī maizes daudzums un veids. Arī lielā Dānijas kohortas pētījumā, kas ilga 12 gadus, neatrada saistību starp pilngraudu produktu lietošanu un PV risku [Egeberg, 2011]. Savukārt pētījums Islandē rāda, ka tieši rudzu maizes lietošana pusaudžu vecumā (14-19 gadu vecumā) saistīta ar mazāku PV risku, šo efektu saistot ar lignānu un šķiedrvielu darbību, jo auzām un pilngraudu kviešu maizei nebija ietekmes uz PV risku [Torfadottir, 2012]. Mēs ievācām datus par maizes lietošanu tikai pēdējā gada laikā, tāpēc nevaram analizēt uztura ietekmi uz PV attīstības risku agrīnos dzīves posmos. 
N̦emot vērā pieaugošo interesi par pilngraudu protektīvo iedarbību, kur galvenā loma ir šksiedrvielu kompleksam [Slavin, 2004], ir svarīgi noskaidrot galvenos šķiedrvielu avotus. Mūsu pētījumā galvenais šķiedrvielu avots abās pētījuma grupās bija graudaugi (41\%), kam sekoja dārzeņi (20\%) un aug̣̣i (18\%). Arī lielākajā daḷā Eiropas valstu vīriešiem pēc 50 gadu vecuma galvenais šķiedrvielu avots uzturā bija graudaugi (40\%), dārzeņi un aug̣̦i veidoja katrs 15\% no visu uzņemto šķiedrvielu daudzuma. Eiropas dienviddaḷā sakṇaugu, citu dārzeņu un augl̦u proporcija bija augstāka [Suzuki, 2009]. EPIC pêtījumā visvairāk šķiedrvielu uzturā bija vīriešiem Dānijā un Spānijā (Somija nebija iekḷauta šajā pētījumā), vismazāk - Zviedrijā. Mūsu pētījumā no graudaugiem rudzu maize ieņēma visnozīmīgāko vietu un bija galvenais šķiedrvielu avots. Arī Somijā galvenais šķiedrvielu avots ir maize [Lang, 2003, Nordic Council of Ministers 2002]. Šksiedrvielu daudzumu uzturā var zināmā mērā uzskatīt par vienu no „veselīga uztura indikatoriem”, jo tas negatīvi korelēja ar kopējo un piesātināto tauku daudzumu uzturā abās grupās. Šķiedrvielu daudzums uzturā abās grupās neatšķīrās. Arī EPIC pētījumā netika atrasta saistība starp kopējo šķiedrvielu un atsevišķi graudaugu šksiedrvielu daudzumu uzturā un PV risku [Suzuki, 2009], kaut iepriekš Itālijas gadījumu kontroles pētījumā bija aprakstīta negatīva saistība starp PV risku un šķiedrvielu daudzumu uzturā [Pelucchi, 2004].

Mēs nekonstatējām saistību šķiedrvielu daudzumam uzturā ne ar SHBG, ne ar PSA nevienā no pētījuma grupām, kaut arī aprakstīts, ka produkti, kuros ir daudz šķiedrvielu un vienlaikus arī lignāni, mazina PV risku, paaugstinot SHBG un samazinot PSA līmeni [Adlercreutz, 2002].

\subsection{Alkilrezorcīni un lignāni uzturā}

AR mediānais daudzums uzturā pēdējā gada laikā bija 55,8 mg/d, un atšķkirības starp grupām netika konstatētas. Šis daudzums ir līdzīgs tam, kas konstatēts Somijā, Dānijā, savukārt Lielbritānijā tas ir ievērojami zemāks (11,9 mg/d). Savukārt atsevišķi indivīdi uzṇem līdz pat $100 \mathrm{mg} / \mathrm{d}$ [Ross, 2005]. Apmēram puse Lielbritānijas iedzīvotāju un ap 3\% Zviedrijas iedzīvotāju uzturā vispār neuzṇēma pārtikas produktus, kas satur AR. Visi mūsu pētîjuma dalībnieki uzturā regulāri lietoja maizi, tātad uzñēma arī AR. Tāpat kā citos pētījumos, AR daudzums uzturā korelēja ar maizes, rudzu maizes un šķiedrvielu daudzumu uzturā [Ross, 2012a,b]. 
Novērtējot AR daudzumu uzturā, pētîjuma stiprā puse bija tā, ka pētījuma gaitā tika noskaidrota AR koncentrācija dažādos Latvijas maizes veidos [Meija, 2013a]. Savukārt pētījumā iegūto datu precizitāti ierobežoja tas, ka ne vienmēr pētījuma dalībnieki spēja precīzi definēt maizes veidu, ko lietojuši, īpaši attiecībā uz sēklu un kliju maizi. Ar̄̄ dažādi rudzu maizes veidi visbiežāk satur kviešu miltus dažādās proporcijās, kam patērētājs bieži nepievērš uzmanību.

Lignānu mediānais daudzums uzturā pēdējā gada laikā bija $2782 \mu \mathrm{g} / \mathrm{d}$, un starp abām pētījuma grupām nebija atšķirību kopējā uzņemtā lignānu daudzumā un atseviškşu lignānu daudzumā. Mēs analizējām četru (SECO, MAT, LAR, PIN) lignānu veidu daudzumu uzturā, papildus novērtējām arī SYR un MED, tomēr šo divu lignānu veidu daudzumu novērtējām tikai maizē. Pašlaik nav daudz datu par SYR un MED daudzumu maizē, bet ir zināms, ka SYR lielos daudzumos ir rudzos [Adlercreutz, 2010], tāpēc to svarīgi novērtēt populācijās, kur daudz lieto rudzu maizi, kādi ir Latvijas iedzīvotāji. Daudzos iepriekšējos pētījumos aprakstīts tikai SECO un MAT daudzums uzturā. Salīdzināsim lignānu daudzumu tikai ar tiem pētījumiem, kur novērtēts vismaz četru lignānu veidu daudzums. Tomēr jāpiezīmēe, ka salīdzinājumus veikt nav viegli, jo dažādos pētījumos tikušas izmantotas atšksirīgas metodes, lai novērtētu uzņemtā uztura daudzumu. Daļā pêtījumu izmantotas uztura dienasgrāmatas [Milder, 2005a; Nurmi 2010; Pellegreni, 2010], citos pētījumos izmantotas uztura biežuma aptaujas anketas [Hedelin, 2006, Touilland, 2007; Suzuki, 2008], un tikai vienā pētījumā izmantota 24 h atcerēšanās anketa [Zamora-Ros, 2012]. Vidējais lignānu daudzums uzturā Latvijas pētījumā bija lielāks nekā lignānu daudzums uzturā vīriešiem un sievietēm Nīderlandē un Itālijā [Milder, 2005a; Pellegrini, 2010], sievietēm Francijā un Kanādā [Touillaud, 2007; Cotterchio, 2008] un vīriešiem Somijā [Nurmi, 2010]. Mediānais lignānu daudzums uzturā bija arī lielāks nekā mediānais lignānu daudzums uzturā Eiropas iedzīvotājiem nesen publicētajā EPIC pētījumā, kas ietvēra 10 Eiropas valstu kohortu [Zamora-Ros, 2012]. Ja salīdzina lignānu daudzumu uzturā ar citiem pētījumiem, kur tika analizēts sešu lignānu veidu daudzums, mediānais daudzums Latvijas vīriešiem bija mazāks nekā Somijas vīriešiem [Hedelin, 2006]. Novērtējot atsevišķu lignānu daudzumu uzturā, mūsu pētījumā dominēja SECO, kas saskanēja ar Kanādas un Itālijas datiem [Cotterchio, 2008; Pellegrini, 2010], savukārt citos pētījumos dominēja LAR un PIN [Milder, 2005a; Touilland, 2007; Nurmi, 2010, Zamora-Ros, 2012]. Galvenais lignānu avots vīriešiem bija sēklu un rudzu maize (86\%), cits nozīmīgs lignānu avots bija linsēklas (7\%). Šie rezultāti saskan ar datiem par lignānu avotiem uzturā Zviedrijas 
un Somijas vīriešiem, lai gan Zviedrijā un Somijā visnozīmīgākais avots bija rudzu maize, turpretī Latvijā - sēklu maize [Hedelin, 2006; Nurmi, 2010]. Savukārt Nīderlandē galvenais lignānu avots bija tēja un kafija (30\%) [Milder, 2005a], Itālijā vīns [Pellegrini, 2010]. EPIC pētījuma dati norādīja, ka Vidusjūras reǵiona valstīs galvenie lignānu avoti bija aug̣̦i (31\%), dārzeņi (26\%) un vīns (8\%), kamēr pārējās valstīs dominēja dārzeņi (23\%) un graudaugu produkti (20\%) [Zamora-Ros, 2012]. Līdzịgi iepriekš ziņotajam [Milder, 2005a; Suzuki, 2008], arī mūsu pētījumā lignānu daudzums korelēja ar šksiedrvielu daudzumu uzturā, ko izskaidro fakts, ka galvenie lignānu avoti bija šķiedrvielām bagāta maize un linsēklas. Citos pētījumos norādīts, ka lignānu daudzums uzturā pozitīvi korelē ar daudziem veselīga dzīvesveida rādītājiem [Milder, 2005a; Zamora-Ros, 2012]. Mēs atradām tikai daḷēju saistību - statistiski nozīmīgi augstāks lignānu blīvums (g/1000 kcal) uzturā bija nesmēķētājiem, bet neatradām saistību ar ĶMI un izglītības līmeni.

Mūsu rezultāti norāda, ka vīrieši Latvijā 45-80 gadu vecumā salīdzinoši vairāk nekā citās valstīs ar uzturu uzṇem tādas protektīvas vielas kā lignānus un šķiedrvielas [Touillaud, 2007; Cotterchio, 2008; Nurmi, 2010; Pellegrini, 2010; Zamora-Ros R, 2012]. Tomēr hormonāli atkarīgo audzēju prevalence ir augsta [Slimību profilakses un kontroles centrs, 2012]. Skaidrojums varētu būt lielais tauku daudzums uzturā. Gan kopējais, gan piesātināto tauku daudzums uzturā ievērojami pārsniedz rekomendēto daudzumu. Tauki kavē ENL veidošanos zarnās [Adlercreutz, 2010]. Turklāt tauku/ graudaugu šķiedrvielu (g/g) attiecība bija 8,8 un olbaltumvielu/graudaugu šķiedrvielu attiecība (g/g) arī bija augsta - 9,3. Agrākos gados ir bijuši pētījumi, kas norāda, ka, jo augstākas ir šīs minētās attiecības, jo augstāks ir krūts vēža risks [Adlercreutz, 1989, a,b], par PV šādu pētījumu nav. Diemžēl iespējas salīdzināt mūsu pētījuma uztura datu rezultātus ar citiem pētījumiem par Latvijas iedzīvotāju uzturu ir ierobežotas. Latvijā regulāri no 2002. gada tiek veikts pētījums par veselību ietekmējošiem paradumiem, tostarp arī uztura paradumiem (Finbalt veselības monitorings) [Pudule, 2011], kurā iekḷauti iedzīvotāji 15-64 gadu vecumā. Ir bijis vēl viens liels pētījums „Latvijas iedzīvotāju visaptverošais pārtikas patēriņa pētījums", kas ietvēra iedzīvotājus 19-64 gadu vecumā [Nacionālais diagnostikas centrs, PVD Pārtikas centrs, Pārtikas un veterinārā dienesta Pārtikas centrs, 2009]. Šajā pêtījumā iegūtie rezultāti jāvērtē piesardzīgi, jo, lai gan vīriešu vidējais ĶMI bija $26,4 \mathrm{~kg} / \mathrm{m}^{2}$, vidējais uzṇemto kcal daudzums dienā bija $2200 \mathrm{kcal}$, kas ir neatbilstoši maz, līdz ar to jādomā, ka arī pārējo uzturvielu daudzums uzturā novērtēts par zemu (šksiedrvielas 20 g), turklāt nav arī 
atsevišķi apskatītas vecuma grupas. Zināms, ka vēsturiski Latvijā taukus lietojuši lielos daudzumos. Uztura laboratorijas iegūtie dati par Latvijas iedzīvotāju uzturu laika periodā no 1983. līdz 1991. gadam rādīja, ka cilvēks dienā apēdis 146-174 g tauku, tauki devuši 40-42\% no visas enerğijas un $87 \%$ bijuši dzīvnieku tauki [Zariņš, 2009]. Kaut vairākus gadu desmitus iepriekš iegūtie dati ir aptuveni, jo bija citas uztura datu ievākšanas metodes (piemēram, reǵistrēja, cik maisus kartupeḷu ǵimene izēd gada laikā), tomēr minētie rezultāti ir līdzīgi ar mūsu rezultātiem par tauku daudzumu un veidu vecāku vīriešu uzturā, kas, iespējams, norāda, ka vecākā paaudze uztura paradumus maina lēni.

Mūsu pētījuma ierobežojumi saistîti ar uztura biežuma aptaujas anketas lietošanu, kas neizbēgami saistīta ar kḷūdas iespēju. Mēs lietojām Kanādas lignānu datu bāzi [Thompson, 2006], jo tā bija visplašākā pieejamā datu bāze, kas satur četrus lignānu veidus. Saprotams, ka lignānu daudzums Latvijas produktos nav identisks ar lignānu daudzumu Kanādas augos, jo to ietekmē augu daudzveidība un geogrāfiskais stāvoklis [Milder, 2005b]. Arī izmantotā datu bāze nav piln̄̄ga, tā neietver piln̄̄gi visus Latvijas iedzīvotāju lignānu avotus. Lielākajai daļai produktu izmantotas četru lignānu veidu vērtības, tikai maizei - sešu lignānu veidu vērtības, tāpēc, iespējams, lignānu patiesais daudzums uzturā ir augstāks. Tomēr mūsu pêtījums ir pirmais, kur analizēts lignānu daudzums un avoti uzturā vecākiem vīriešiem Latvijā. Pētījuma stiprās puses ir tās, ka tika izvērtēts četru lignānu veidu un maizē - sešu lignānu veidu daudzums, kas nodrošina vērtīgākus rezultātus salīdzinājumā ar pētījumiem, kas novērtējuši tikai divu lignānu veidu daudzumu uzturā. Uztura biežuma aptaujas anketas izmantošana uztura datu novērtēšanai dod iespēju izvērtēt uztura ieradumus ilgākā laika periodā, kam ir lielāka nozīme, nekā novērtējot uztura ieradumus tikai dažas dienas, piemēram, lietojot uztura dienasgrāmatu. Turklāt mūsu pētījuma dizains tika speciāli izstrādāts, lai novērtētu lignānu un AR daudzumu uzturā, un to veica kvalificēti uztura speciālisti. Būtiski, ka tika noteiktas lignānu vērtības nozīmīgākajos lignānu uztura avotos Latvijā dažādos Latvijas maizes veidos. Saprotams, jāpiebilst, ka pētījuma dalībnieki uzturā lietoja daudzus dažādus maizes veidus, un ne visos gadījumos lignānu vērtība šajos maizes veidos atbilda tām vērtībām, kas tika noteiktas populārākajos Latvijas maizes veidos un izmantotas datu apstrādē.

Kopsavilkumā ir jāmin, ka lignānu daudzums uzturā vecākiem vīriešiem Latvijā ir augsts. No lignāniem visvairāk tika uzṇemts SECO. Starp PV un kontroles grupas vīriešiem nebija atšķirību uzņemto lignānu daudzuma ziņā. Lignānu galvenais avots 
uzturā ir maize. Potenciāli protektīvo lignānu iedarbību, iespējams, kavē lielais tauku daudzums uzturā. Lai precīzāk novērtētu lignānu daudzumu Latvijas iedzīvotāju uzturā, jāveic pētījumi ar lielāku dalībnieku skaitu, jāpaplašina lignānu datubāze un jānosaka lignānu daudzums plašākā vietējo produktu klāstā.

\subsection{Alkilrezorcīnu metabolīti}

DHPPA koncentrācija 12 h nakts urīnā un plazmā būtiski neatšks̄īās no citos pētījumos iegūtajiem rezultātiem [Guyman, 2008; Aubertin-Leheudre, 2010b]. Cik mums zināms, pašlaik dati par DHBA un DHPPA koncentrāciju 12 h dienas urīnā nekur pasaulē nav publicēti vispār.

Datus par AR metabolītu koncentrācijas plazmā un urīnā saistību ar uzturu mēs analizējām divos veidos - izmantojot trīs dienu vidējos datus un atsevišķi trešās dienas uztura datus. Mēs katru no abām pētîjuma grupām iedalījām vēl divās grupās - kas bija ēduši rudzu maizi trešajā uztura dienasgrāmatas rakstišanas dienā un kas nebija ēduši rudzu maizi. Šāds dalījums tika veikts, ņemot vērā datus, ka rudzu maize ir galvenais Šķiedrvielu un AR avots vecākiem vīriešiem Latvijā [Meija, 2012].

Abās pētījuma grupās tika konstatēta saistība starp visiem AR metabolīitiem urīnā (DHBA 12 h dienas, 12 h nakts un 24 h urīnā; DHPPA 12 h dienas, 12 h nakts un 24 h urīnā) un maizes şķiedrvielu, rudzu maizes un rudzu maizes šķiedrvielu daudzumu pēdējo 3 dienu uzturā. Izṇēmums: PV grupā netika konstatēta saistība starp DHPPA 12 h dienas urīnā un maizes, rudzu maizes, kā arī rudzu maizes šķiedrvielu daudzumu uzturā. Kontroles grupā atradām saistību starp AR metabolītiem un maizes şķiedrvielu daudzumu trešās dienas uzturā, kamēr PV grupā šādas saistības nebija. Apkopojot iegūtos datus, secinājām, ka DHPPA 12 h nakts urīnā ir vispiemērotākais AR metabolīts, ko var izmantot par biomarķieri maizes šķiedrvielu, rudzu maizes un rudzu maizes šķiedrvielu daudzumam uzturā. DHPPA 12 h nakts urīnā abās grupā korelē gan ar maizes daudzumu, gan maizes šksiedrvielu daudzumu, gan rudzu maizes daudzumu, rudzu maizes šķiedrvielu un AR daudzumu pēdējo 3 dienu uzturā. Konstatētās korelācijas (r) PV grupā bija ciešākas. Citu AR metabolītu saistība ar uztura datiem nebija tik cieša un būtiska. Mūsu dati sakrīt ar citu pētījumu datiem, kas atzīst DHPPA $12 \mathrm{~h}$ nakts urīnā par rādītāju, kas atspoguḷo pilngraudu kviešu un rudzu maizes daudzumu uzturā [Guyman, 2008]. Tiek piedāvāts lietot ne tikai AR metabolītus, bet arī AR kā uztura pilngraudu marķierus [Ross, 2012a], bet AR kā marķieri var izvērtēt tikai 
plazmā, jo to koncentrācija urīnā ir pārāk niecīga. Epidemiologiskajos pētījumos bieži priekšroka dodama neinvazīviem izmeklējumiem, tādiem kā urīna izmeklējumi, salīdzinājumā ar asins plazmas izmeklējumiem. Uztura aptauju datu ticamība vienmēr ir bijusi aktuāla problēma lielajos epidemiologiskajos pētījumos. Atbilstoša biomarķiera lietošana, novērtējot uzņemto pilngraudu kviešu vai rudzu daudzumu, nodrošinātu lielāku iegūto datu ticamību un iespēju iegūt informāciju situācijās, kad nav iespējams iegūt precīzus uztura datus. Tā kā AR ir atrodami vienīgi kviešu un rudzu graudu ārējā dal̦ā, tie atrodami tikai tādos pārtikas produktos, kur izmantotas kviešu vai rudzu klijas. Daudzās valstīs tiek izmantoti pilngraudu milti, un šajā gadījumā AR metabolīti ir uzskatāmi par marķieri pilngraudu kviešu vai rudzu maizes daudzumam uzturā. Tā kā Latvijā maizes ražošanā gandrīz netiek izmantoti pilngraudu kviešu milti, tad DHPPA 12 h nakts urīnā būtu jāuzskata par marķieri rudzu maizes, rudzu šķiedrvielu un kviešu kliju daudzumam uzturā pēdējo trīs dienu laikā.

Mēs konstatējām statistiski nozīmīgas atšķirības starp abām pētījuma grupām:

1) PV grupā DHPPA koncentrācija plazmā bija statistiski ticami augstāka nekā kontroles grupā;

2) PV grupā DHPPA plazmā korelēja ar kopējo maizes, maizes šķiedrvielu, rudzu maizes un rudzu maizes šķiedrvielu daudzumu 3 dienu vidējos uztura datos, kas netika konstatēts kontroles grupā;

3) PV grupā AR metabolītu koncentrācija urīnā (izṇemot DHPPA 12 h dienas urīnā) korelēja ar vidējiem trīs dienu uztura datiem, bet nekorelēja ar trešās dienas uztura datiem. Kontroles grupā minētās korelācijas bija gan ar 3 dienu vidējiem, gan atsevišķi ar trešās dienas uztura datiem;

4) PV grupā DHPPA 12 h dienas urīnā nekorelēja ar maizes šķiedrvielu, rudzu maizes daudzumu un rudzu maizes šķiedrvielu daudzumu 3 dienu uzturā, savukārt kontroles grupā šāda korelācija tika konstatēta;

5) PV grupā DHBA un DHPPA koncentrācija nakts urīnā bija būtiski augstāka nekā dienas urīnā. Kontroles grupā šādas atšķirības nebija;

6) PV grupā plazmā saglabājās augsta DHPPA koncentrācija neatkarīgi no tā, vai rudzu maize tika ēsta vai ne. Kontroles grupā savukārt bija statistiski ticama atšķirība DHPPA plazmas koncentrācijā starp tiem, kas bija, un tiem, kas nebija ēduši rudzu maizi.

Šie iegūtie dati liek domāt, ka PV pacientiem, iespējams, ir kavēts AR metabolisms, salīdzinot ar kontroles grupas vīriešiem. Mūsu datos nav norādījumu par 
nieru funkcijas traucējumiem. Iespējams, ka ir izmainīts AR metabolisms aknās, kur notiek AR sadalīšanās par DHBA un DHPPA. AR metabolisms aknās ir līdzīgs tokoferola metabolismam. To realizē citohromu sistēma P 450, kur pirmais solis ir funkcionālo grupu oksidēšanās un AR molekulas saškselšanās, kā rezultātā rodas ūden̄̄ šķīstoši savienojumi. Asinīs un urīnā var noteikt abu AR metabolītu (DHBA un DHPPA) gan brīvās, gan konjugētās formas (konjugētas ar glikuronskābi vai sērskābi).Veseliem jauniem cilvēkiem DHPPA koncentrācija vispirms sasniedz maksimumu urīnā un tikai pēc tam asinīs [Söderholm 2009, 2011]. To nosaka augstā DHPPA glikuronizācijas pakāpe (39\%), kas palielina DHPPA šķīdību ūdenī, un tāpēc tas ātrāk caur nierēm izfiltrējas urīnā (salīdzinoši ar DHBA, kura koncentrāciju plazmā mēs nepētījām). Iespējams, ka PV pacientiem aknās ir kavēta glikuronizēšanās, tāpēc asinīs saglabājas augstāka DHPPA koncentrācija. Pastāv arī cits iemesls - iespējams, ka PV pacientiem ir izmainīta enterohepatiskās cirkulācijas kinētika. Iepriekšējie pētījumi ar veseliem cilvēkiem norādīja, ka naktī ir iespējama palēnināta AR metabolītu ekskrēcija, jo nakts urīna DHPPA un DHBA ekskrēcijas pakāpe bija zemāka nekā urīnam, kas vākts dienas laikā. Mūsu pētījumā PV pacientiem DHPPA un DHBA koncentrācija nakts urīnā bija augstāka nekā dienas urīnā, kas ir vēl viena liecība tam, ka PV pacientiem ir kavēts AR metabolisms - tie ilgāk saglabājas asinīs un vēlāk nonāk urīnā. Tāpēc plazmā saglabājas augsta AR metabolīta DHPPA koncentrācija neatkarīgi no tā, vai iepriekšējā dienā viņi bija ēduši rudzu maizi vai ne. Būtiski, ka šie rezultāti sakrita ar intervences pētījuma rezultātiem (skat. nākamo diskusijas daļu „Rudzu maizes lietošana PV pacientu uzturā’”). Turklāt metabolīti urīnā neatspoguḷo iepriekšèjās dienas uzturu, kā tas konstatēts kontroles grupā, bet gan liecina par uzturu pirms vienas un divām dienām. Vēl cits varbūtējais skaidrojums ir šāds: iespējams, ka PV pacientiem pēc metabolisma procesiem aknās ir izmain̄its AR eliminācijas veids. Zināms, ka AR metabolizējas līdzīgi tokoferoliem un, pieaugot devai, eliminācija mainās no ekskrēcijas ar urīnu uz biliāro ekskrēciju [Landberg, 2009a]. Iespējams, ka šie procesi ir izmainīti PV pacientiem, jo no kontroles grupas neatšķiras AR daudzums uzturā, kā arī no kontroles grupas neatšķiras AR metabolītu daudzums urīnā. Tomēr ir konstatētas AR metabolītu koncentrācijas atšķirības plazmā. Līdz ar to kontroles grupā, pieaugot AR devai uzturā, pastāv iespēja, ka daļa AR metabolītu tiek izvadīta, izmantojot biliāro ekskrēciju, bet PV grupā biliārā ekskrēcija netiek izmantota un plazmā saglabājas augsta metabolītu koncentrācija. 
AR absorbcija un metabolisms nav pilnībā izpētīts. Tiek uzskatīts, ka DHPPA urīnā ir îsāks ekskrēcijas laika maksimums, bet garāks T¹/2 nekā DHBA [Söderholm, 2011]. Iespējams, ka atsevišksi AR metabolīti PV pacientiem un kontroles grupas pacientiem dažādā laikā sasniedz mērķa orgānus, kur iesaistās organisma bioloğiskajos procesos un tāpēc to koncentrācijas biologiskajos šķidrumos saistība ar uztura datiem ir atšksirīga abās grupās.

Iespējamais skaidrojums, kāpēc PV pacientiem ir augstāka potenciāli protektīvā AR metabolīta DHPPA koncentrācija plazmā, ir šāds - minētais metabolīts nesasniedz mērķa orgānus, un tā protektīvā darbība ir kavēta. Jādomā, ka, lai precīzāk izvērtētu AR metabolītu kinētiku bioloǵiskajos šķidrumos, tie jāanalizē saistībā ar iepriekšējo piecu dienu uztura dienasgrāmatas datiem, vienlaikus arī ņemot vērā precīzus maizes lietošanas pulksteņlaikus.

Pētījuma stiprās puses ir: iegūtā saistība laikā starp uztura datu vākšanu (uztura dienasgrāmatas aizpildīšanu) un urīna vākšanas laikiem un asins plazmas analīžu veikšanu, kā arī diennakts laika reǵistrēšana. Mēs atšķirībā no citiem pētîjumiem atsevišķi analizējām 3 dienu uztura datus un trešo dienu atsevišķi, kas ļauj detalizēti spriest par AR kinētiku biologiskajās sistēmās. Pētījuma ierobežojumi ir samērā nelielais dalībnieku skaits, kas reprezentē tikai dalı no relatīvi homogēnās populācijas, tāpēc iegūtos rezultātus pilnībā nevar attiecināt uz visu populāciju. Uztura dienasgrāmatas tika aizpildītas dažādās sezonās, līdz ar to uzṇemtais uzturs atšķ̄īās. Tomēr jāpiebilst, ka maizes lietošanas ieradumus sezonalitāte ietekmē nebūtiski.

Kopsavilkums: DHPPA $12 \mathrm{~h}$ nakts urīnā vislabāk korelē ar rudzu maizes daudzumu un rudzu maizes šķiedrvielu daudzumu uzturā, kas padara DHPPA par vispiemērotāko biomarķieri rudzu maizes un rudzu šķiedrvielu daudzuma izvērtēšanai uzturā. Iespējams, ka PV pacientiem ir kavēts AR metabolisms.

\subsection{Enterolaktons}

Abās pētījuma grupās ENL koncentrācija plazmā, salīdzinot ar EPIC pētījuma datiem (fitoestrogēnu koncentrācija plazmā Eiropas pieaugušajiem iedzīvotājiem [Peeters, 2007]), bija līdzīga kā iedzīvotājiem Dānijāa, savukārt Itālijas iedzīvotājiem ENL koncentrācija plazmā bija ievērojami zemāka. Somijas iedzīvotājiem ENL koncentrācija plazmā bija līdzīga Latvijas rādītājiem [Kilkkinen, 2003a]. ENL koncentrācija urīnā bija līdzīga tai, kas konstatēta Somijas vīriešiem [Nurmi, 2010]. 
Atšķirības ENL koncentrācijā starp pētījuma grupām netika atrastas nevienā ENL izmeklējumā, kas saskan ar iepriekš veiktajiem pētījumiem [Kilkkinen, 2003b; Stattin, 2004; Ward, 2008]. Skotijas pētījuma rezultāti uzrādīja atšķirības - kontroles grupā bija augstāka seruma ENL koncentrācija nekā PV grupā [Heald, 2007]. Savukārt viens Zviedrijas pētījums norādīja, ka ENL koncentrācijas serumā saistība ar PV risku nav lineāra un tieši vidējas ENL seruma koncentrācijas (15-24 nmol/L) saistītas ar samazinātu PV risku [Hedelin, 2006]. Salīdzinoši nelielā pētījuma dalībnieku skaita dēl mēs nevaram izvērtēt šādas saistības. Pašlaik mūsu rezultāti neapstiprina ENL protektīvo iedarbību un nav pretrunā ar iepriekš veikto pētījumu rezultātiem.

PV grupā netika atrasta ENL korelācija ar PSA, kas saskan ar citu pētījumu rezultātiem [Hedelin, 2006; Venkitaraman, 2008]. Lai gan kontroles grupā tika atrasta pozitīva korelācija, to nevar interpretēt kā ENL negatīvo efektu, jo PSA lielākajai daḷai dalībnieku bija normas robežās.

Nevienā grupā netika atrasta ENL koncentrācijas saistība ar dzimumhormonu koncentrāciju. Līdz šim šì saistība ir vairāk pētīta sievietēm postmenopauzes vecumā, un tie pārsvarā ir bijuši intervences pētījumi ar lielām lignānu devām, kas ietekmējis dzimumhormonu koncentrāciju, kā, piemēram, paaugstinājis SHBG līmeni [Wu, 2006]. Savukārt EPIC Norfolk pētījumā konstatēja, ka ENL ir pozitīva saistība ar androgēnu līmeni plazmā un šo saistību ietekmē genētiski cēloņi, bet saistība ar SHBG netika atrasta [Low, 2005]. Paaugstināts androgēnu līmeni ir hipotētiski saistīts ar paaugstinātu PV risku, tādā gadījumā lignānu iedarbību varētu uzskatīt par nelabvēlīgu. Tajā pašā laikā joprojām nav skaidras saistības starp cirkulējošo androgēnu koncentrāciju un PV risku, jo daudzos pētîjumos nav konstatēta saistība starp paaugstinātu androgēnu līmeni un palielinātu PV risku [Teede, 2004]. Cirkulējošie androgēni var tikt pārvērsti par estrogēniem, kas arī var palielināt PV risku. Saistības trūkums starp ENL koncentrāciju plazmā un urīnā un dzimumhormonu koncentrāciju nav pretrunā ar iepriekšējiem pētījumiem, jo kopumā pêtījumu rezultāti nav viendabīgi. Joprojām nav piln̄̄gas skaidrības par dažādu dzimumhormonu lomu PV attīstības procesā, un lielākā dą̧a pētnieku uzskata, ka saistībā ar PV risku fitoestrogēniem ir protektīva ietekme.

Mēs neatradām arī saistību starp ENL koncentrāciju plazmā vai urīnā un D vitamīna koncentrāciju plazmā. Kaut arī ir izvirzīta hipotēze par to, ka fitoestrogēni (genisteīns) kopā ar D vitamīnu var darboties sinerǵiski protektīvi, kavējot PV attīstību [Swami, 2007], tieši par lignānu mijiedarbību ar D vitamīnu datu nav. Mūsu rezultāti 
norādīja, ka lielākajai daḷai vīriešu gan PV, gan kontroles grupā bija D vitamīna deficīts un/vai nepietiekamība, tāpēc par potenciāli protektīvo iedarbību spriest nevar.

PV grupā netika konstatētas atšķirības starp ENL koncentrāciju 12 h dienas, 12 h nakts, 24 h urīnā un plazmā starp tiem, kas bija lietojuši antibiotikas pēdējā gada laikā, un tiem, kuri nebija tās lietojuši, turpretī kontroles grupā statistiski nozīmīga atšķirība tika konstatēta. Šie rezultāti norāda, ka PV grupā, iespējams, ir izmainīta zarnu mikroflora pēc antibiotiku lietošanas (iespējams, normālā mikroflora atjaunojas vēlāk nekā veseliem vīriešiem) vai arī PV slimniekiem jau sākotnēji ir atšķirīga mikroflora, mazāks enterolignānus producējošu baktēriju daudzums, tāpēc ENL veidošanās zarnās no uztura lignāniem ir traucēta.

Analizējot 3 dienu vidējos uztura datus, PV grupā ENL plazmā un urīnā pozitīvi korelēja ar maizes, maizes šķiedrvielu, sēklu maizes daudzumu, bet nekorelēja ar rudzu maizes, maizes lignānu un kopējo lignānu daudzumu uzturā. Atsevišşki analizējot trešās dienas datus, korelācijas tika atrastas tikai tajā PV grupā, kas nebija lietojuši antibiotikas pēdējā gada laikā. Šiem PV pacientiem ENL 12 h dienas urīnā korelēja ar maizes, rudzu maizes, maizes šķiedrvielu, rudzu maizes šķiedrvielu, maizes lignānu un kopējo lignānu daudzumu uzturā. ENL plazmā korelēja ar rudzu maizes daudzumu uzturā. ENL un uztura datu korelācijas mūsu pētîjumā PV grupā saskan ar pētījumu rezultātiem tajās valstīs, kur galvenais lignānu avots uzturā ir maize un rudzu maize, piemēram, Somija. Savukārt valstīs, kur galvenais lignānu avots uzturā ir dzērieni, tādi kā vīns, kafija, tēja (Nīderlandē), vai augḷi un dārzeņi (Francijāa), ENL nekorelē ne tikai ar pilngraudu un rudzu maizes daudzumu uzturā, bet arī ar šķiedrvielu daudzumu uzturā [Adlercreutz, 2010]. Jādomā, ka PV grupā, kas nebija lietojuši antibiotikas pēdējā gada laikā, bija ātrāka lignānu uzsūkšanās un metabolisms, jo tikai tiem tika atrastas korelācijas ar trešās dienas uztura datiem. Šis rezultāts varētu dot papildu norādījumu, ka tiem vīriešiem, kas saslimuši ar PV, antibiotiku lietošanas negatīvā ietekme saglabājās vēl ilgstošāk nekā kontroles grupas vīriešiem (zināms, ka antibiotikas maina zarnu mikrofloru līdz pat 12-14 mēnešiem [Adlercreutz, 2010]).

Kontroles grupā, analizējot 3 dienu vidējos uztura datus, korelācijas tika atrastas vien̄̄gi starp ENL koncentrāciju 12 h dienas urīnā un kopējo lignānu, kā arī maizes lignānu daudzumu uzturā. Sēklu maizes daudzums negatīvi korelēja ar ENL koncentrāciju plazmā un urīnā. Kontroles grupā trešās dienas uztura datiem ar ENL plazmā un urīnā saistības nebija. 
Iespējams, sēklas ar visu apvalka daḷu kavē lignānu uzsūkšanos, savukārt izmainītais ENL metabolisms PV pacientiem vēl vairāk kavē protektīvo vielu nonākšanu audos, kur metabolītu uzkrāšanās rada ilūziju par pozitīvu korelāciju starp maizes lignānu un ENL koncentrācijām. Jāpiez̄̄mē arī, ka ne vienmēr informācija par maizes veidu uzturā ir bijusi precīza, jo pētījuma dalībnieki norādīja, ka lietojuši ,sēklukliju maizi”, tāpēc iespējams, ka daḷā gadījumu tā bija tikai maize ar kliju piedevu, bet bez sēklām, kas ietekmēja rezultātus.

Mūsu rezultāti nav pretrunā ar citu pētījumu rezultātiem. Dati par ENL koncentrāciju plazmā vai urīnā saistību ar lignānu un atsevišķi rudzu maizes daudzumu uzturā ir pretrunīgi. Daḷā pētījumu tika konstatēta saistība starp ENL koncentrāciju serumā vai urīnā un lignānu daudzumu uzturā [Kilkkinen, 2003a; Milder, 2007]. Ir pētījumi, kur nav atrasta saistība ne PV, ne kontroles grupā [Hedelin, 2006].

Lignānu biologiiskā aktivitāte ir sarežğîta. Pēc absorbēšanās tie tiek konjugēti ar glikuronskābi vai sērskābi. Līdz galam nav noskaidrots, vai konjugētās lignānu formas tikpat efektīvi saistās ar estrogēnu receptoriem kā nekonjugētās formas. Turklāt lignānu uzsūkšanos ietekmē arī citi faktori. Tauki kavē lignānu uzsūkšanos, tāpēc lielais tauku daudzums uzturā var būt viens no cēloṇiem, kāpēc ENL saistība ar lignānu daudzumu uzturā bija tikai dal̄ēja. Tomēr galvenais faktors, kas nosaka ENL veidošanos, ir zarnu mikroflora, ko nebija iespējams novērtēt mūsu pētījumā.

\subsection{Rudzu maizes lietošana PV pacientu uzturā}

Mūsu intervences pētījumā rudzu maizes lietošana nozīmīgi pazemināja PSA salīdzinājumā ar baltmaizes (rafinētas kviešu maizes) lietošanu ( $\mathrm{p}=0,016)$, kā arī samazināja PSA koncentrācijas amplitūdu. Izmaiṇas bPSA (brīvais PSA) koncentrācijā netika atrastas. Iepriekš bijuši tikai divi nelieli pêtījumi ar cilvēkiem par pilngraudu rudzu maizes ar augstu šksiedrvielu daudzumu iedarbību uz PSA priekšdziedzera vēža pacientiem. Mūsu pētījuma rezultāti saskan ar Landberga datiem [Landberg, 2010], kas 6 mēnešus ilgā intervences pētījumā ar rudzu maizes produktiem atklāja PSA pazemināšanos par 14\% salīdzinoši ar kviešu maizes produktu lietošanu, bet nekonstatēja bPSA izmaiņas. Citā pêtījumā [Bylund, 2003] šāds rezultāts netika konstatēts. Citi pētījumi, kas norāda uz rudzu ietekmi uz PSA, tika veikti ar dzīvniekiem [Landström, 1998; Bylund, 2003]. Iespējams, ka rezultātu - PSA pazemināšanos pēc rudzu maizes lietošanas - ietekmē arī PSA paaugstināšanās pēc baltmaizes lietošanas (kaut gan PSA 
palielināšanās pēc baltmaizes lietošanas bija statistiski nenozīmīga). PSA izmaiņas dinamikā PV pacientiem, kam netiek piemērota operatīvā terapija, ir viens no būtiskākajiem faktoriem, kas norāda uz PV progresēšanu un nosaka terapijas izvēli [Arlen, 2008].

Izejas posmā (lietojot ikdienas diētu) DHBA un DHBA koncentrācija neatšş̄īās starp tiem, kas bija lietojuši rudzu maizi iepriekšējā dienā pirms analīžu veikšanas, un tiem, kuri nebija maizi lietojuši, kas saskan ar mūsu gadījuma kontroles pētījuma rezultātiem. Analizējot AR metabolītu izmaiņas dažādos pētījuma posmos, DHBA un DHPPA koncentrācija plazmā atšķīrās gan starp izejas posmu (rādītāji, lietojot ikdienas diētu) un pēc kviešu maizes lietošanas. Tāpat AR metabolītu koncentrācijas atšksirības tika konstatētas arī starp izejas posmu un pēc rudzu maizes lietošanas, gan starp posmiem pēc kviešu un rudzu maizes lietošanas. AR metabolītu izmaiņas PV pacientiem intervences pētījuma apstākḷlos pēc rudzu maizes iekḷaušanas uzturā nav līdz šim pētītas, bet ir pētītas AR koncentrācijas izmaiņas PV pacientiem pēc rudzu un kviešu maizes lietošanas nozīmēšanas un atrasta koncentrācijas palielināšanās pēc rudzu maizes lietošanas un koncentrācijas pazemināšanās pēc kviešu maizes lietošanas [Landberg, 2009b], kas saskan ar mūsu pētījuma rezultātiem.

Analizējot dzimumhormonu koncentrācijas izmaiņas pēc rudzu maizes lietošanas, konstatējām SHBG koncentrācijas palielināšanos pēc rudzu maizes lietošanas, salīdzinot ar situāciju pēc kviešu maizes lietošanas. Savukārt izmaiņas testosterona, BAI, LH un FSH koncentrācijā netika atrastas. Bīlundas pētījumā nebija ne SHBG, ne FSH, ne LH koncentrācijas izmaiņu [Bylund, 2003].

ENL koncentrācija mūsu pētījumā samazinājās pēc kviešu maizes lietošanas un pieauga pēc rudzu maizes lietošanas, kas saskan ar Landberga pētījuma datiem [Landberg, 2010].

Pētot rudzu maizes ietekmi uz šūnu apoptozi, nevarējām iegūt statistiski ticamus rezultātus mazā pētījuma dalībnieku skaita un lielās izkliedes dēḷ, tomēr apoptozes pieaugums bija konstatēts 8 no 11 operāciju materiālos. Mūsu rezultāti norāda, ka apoptozes aktivitātei ir tendence pieaugt, un tie saskan ar Bīlundas rezultātiem, kas norādīja, ka pēc rudzu maizes lietošanas nozīmīgi palielinājās apoptozes indekss, savukārt kontroles grupā, kas lietoja kviešu maizi, šādas izmaiņas netika konstatētas [Bylund, 2003]. Iepriekš veiktie pētījumi ar dzīvniekiem liecina par labu šiem rezultātiem [Bylund, 2000]. Iespējamais mehānisms apoptozes pieaugumam ir lignānu iedarbība. Lignāni var ietekmēt PV progresēšanu, iedarbojoties uz SHBG, gan tieši 
kavējot audzēja augšanu, gan arī netieši iedarbojoties uz IGF [Adlercreutz, 2002]. Par labu šai hipotēzei liecina mūsu pētījuma rezultāti, kur pēc rudzu maizes lietošanas pieauga gan lignānu metabolīta ENL koncentrācija, gan arī palielinājās SHBG koncentrācija. Ar lignānu ietekmi var arī skaidrot PSA izmaiņas [Adlercreutz, 2007].

Tomēr nav skaidrs, vai ENL ir vienīgā aktīvā viela, jo citu dzimumhormonu koncentrācija nemainījās, turklāt pieauga arī AR metabolītu DHBA un DHPPA koncentrācija. Tāpēc var piel̦aut, ka darbojas arī citi pilngraudu rudzu maizes bioloǵiskie mehānismi. Rudzu maizes šķiedrvielas nodrošina mazāku enerğijas utilizāciju, jo tievajās zarnās mazinās uzsūkšanās, kamēr palielināts svars, kā arī pārmērīgi liels kcal daudzums uzturā ir PV riska faktori [Hsieh, 2003; Ma, 2008]. Mūsu pētījuma dalībniekiem netika noteikta ķermeņa masa pēc rudzu maizes lietošanas intervences pētījumā, savukārt citos pētījumos vīrieši pēc rudzu maizes lietošanas saglabāja esošo ķermeṇa masu vai pat tā mazinājās, lai gan bija uzṇēmuši vairāk kcal nekā līdz pêtījumam [Landberg, 2010]. Cits iespējamais darbības mehānisms, kas ietekmē PSA līmeni un PV progresēšanu, ir fermentācijas procesi zarnās, ko nodrošina rudzu šķiedrvielas uzturā. Rudzu graudi satur vairāk šķīstošo šķiedrvielu nekā kviešu graudi, ātrāk veidojas īso ķēěu taukskābes, tādas kā acetāti, propionāti un butirāti. Îso ķē̌zu taukskābes, īpaši butirāts, aktivē aknu AMP-atkarīgo proteīnkināzi, kas savukārt regulē enerğijas homeostāzi organismā. AMP-atkarīgā proteīnkināze kavē glikoneoǵenēzi, rezultātā mazinās glikozes producēšana un insulīna sekrēcija [Hu, 2010]. Savukārt insulīns var veicināt PV progresēšanu [Hammarsten, 2005].

Pētījumam bija savas stiprās puses un ierobežojumi. Pētījuma stiprās puses bija intervences pētījumam samērā lielais piesaistīto dalībnieku skaits (n=37) un augstā līdzestība. Ierobežojumi: pētījums nebija akls un nebija salīdzinājuma ar kontroles grupu. Kaut arī mūsu pētījuma rezultāti sakrīt ar citu pētījumu rezultātiem, tomēr, lai interpretētu rezultātus, ir jāturpina pêtījumi ar lielāku dalībnieku skaitu, tie jāveic ilgākā laika periodā un jāizmanto rudzu maize ar vēl augstāku rudzu šķiedrvielu daudzumu (ar pievienotām rudzu šķiedrvielām).

Kopsavilkums. Pētījumā konstatētas liecības, ka rudzu maize, iespējams, kavē PV progresēšanu. Potenciālie darbības mehānismi: SHBG, ENL, DHBA un DHPPA koncentrācijas palielināšanās, kā rezultātā pazeminājās PSA un tika novērota apoptozes rādītāju pieauguma tendence.

Kopsavilkums no gadījuma kontroles un intervences pètījuma par AR un lignānu metabolītu lietošanu. DHPPA koncentrācija plazmā atbilstoši atspoguḷo rudzu maizes un 
rudzu maizes šķiedrvielu daudzumu uzturā intervences pētījuma apstākḷos, kad ilgstošā laika periodā tiek uzņemts konstants maizes daudzums. Savukārt apstākḷlos, kad cilvēks lieto savu ierasto uzturu un maizes daudzums uzturā variē, piemērotāks izmeklējums, kas atspoguḷo rudzu maizes un rudzu maizes šķiedrvielu uzturā, ir DHPPA koncentrācijas noteikšana $12 \mathrm{~h}$ nakts urīnā. Līdzīgi arī ENL intervences pētījuma apstākḷos atspoguḷo uzņemto lignānu, kā arī rudzu maizes daudzumu, savukārt, lietojot ierasto ikdienas uzturu, šāda saistība netiek konstatēta.

\subsection{D vitamīns}

Pētījuma rezultāti rāda, ka abās pētījuma grupās bija izplatīts D vitamīna deficīts un/vai nepietiekamība. Tikai nelielai daļai vīriešu bija rekomendējamais seruma D vitamīna līmenis. Mūsu pētījuma rezultāti tika izvērtēti saskan̄ā ar jaunākajām starptautiskajām un Latvijas Osteoporozes un kaulu metabolo slimību asociācijas vadlīnijām [Holick, 2011; Latvijas Osteoporozes un kaulu metabolo slimību asociācija, 2011], par vēlamo uzskatot D vitamīna seruma koncentrāciju, sākot no 30 ng/mL, kas, iespējams, ir nepietiekama, jo, pētot Latvijas sievietes, konstatēts, ka optimālā D vitamīna koncentrācija, kas nodrošina PTH supresiju, ir vismaz 38 ng/mL. Tādā gadījumā (uzskatot par nepiekamu D vitamīna seruma koncentrāciju, zemāku par 38 ng/mL) optimālā D vitamīna seruma koncentrācija būtu vēl mazākai daļai pētījuma dalībnieku. Mūsu pētījumā iegūtie rezultāti ir līdzīgi kā Latvijas sievietēm postmenopauzes vecumā ziemā, bet D vitamīna līmenis ir ievērojami zemāks par Latvijas sieviešu vidējo D vitamīna seruma koncentrāciju [Lejnieks, 2013]. Mūsu rezultāti atbilst arī citu valstu pētījumu rezultātiem un, iespējams, norāda uz to, ka Latvijā vīriešiem pēc 45 gadu vecuma $\mathrm{D}$ vitamīna deficìts un/vai nepietiekamība ir vēl izteiktāka nekā citos pasaules regiionos. 20-100\% vecāka gadagājuma cilvēku ASV, Kanādā un Eiropā ir D vitamīna deficīts un/vai nepietiekamība [Holick, 2011]. EPIC pētījumā Eiropas valstīs PV pacientiem un kontroles grupā D vitamīna deficīts bija 39\% [Travis, 2009b], savukārt somu populācijā - 50\% [Faupel-Badger, 2007].

Citos pētîjumos [Ahn, 2008; Trump 2009] konstatētas D vitamīna seruma koncentrācijas sezonālas atšķirības. Mūsu datos parādījās tikai D vitamīna seruma koncentrācijas sezonālo atšksirību (PV grupā ziemā un pavasarī bija zemāka D vitamīna koncentrācija, savukārt kontroles grupā zemāka koncentrācija bija tikai pavasarī) tendence bez statistiskas ticamības, ko var skaidrot ar nelielo dalībnieku skaitu katrā grupā.

PV grupā D vitamīna seruma koncentrācija bija augstāka nekā kontroles grupā.

Par D vitamīna iespējamo protektīvo iedarbību, ieskaitot ietekmi uz PSA un dzimumhormoniem, šajā situācijā nevar spriest, jo abās grupās tā koncentrācija ir zema, 
turklāt PV pacientu grupa bija skaitliski neliela. Iespējams, ka seruma D vitamīna līmenis neatspoguḷo D vitamīna koncentrāciju lokālajos audos [Travis, 2009b]. Nav arī pietiekamas informācijas par $\mathrm{D}$ vitamīnu regulējošo enzīmu, kā arī $\mathrm{D}$ vitamīna metabolītu un D vitamīna receptoru aktivitāti normālos priekšdziedzera audos un PV audos in vivo apstākļos. Domājams, ka šos procesus lokālajos audos ietekmē genētiski, epiǵenētiski un citi endogēni un apkārtējās vides faktori, kas pašreizējā posmā vēl nav izpētīti [Donkena, 2011].

D vitamīna daudzums uzturā bija nepietiekams abās grupās. Rekomendējamais D vitamīna daudzums uzturā 19-70 gadu vecumā ir vismaz 600 SV/d (starptautiskās vien̄̄bas dienā) un no 70 gadu vecuma -vismaz 800 SV/d [Holick, 2011]. Mūsu rezultāti saskan ar datiem par D vitamīna nepietiekamo daudzumu uzturā tādās valstīs kā Austrija, Vācija, Lielbritānija, Itālija, Nīderlande, Norvēǵija, İrija [European Food Safety Authority, 2006] un ar iepriekšējiem pētījumiem Latvijā [Nacionālais diagnostikas centrs, 2009]. Galvenais D vitamīna uztura avots abās pētījuma grupās bija zivis, ko abās pētījuma grupās lieto nepietiekami daudz. Tā kā abas pētāmās grupas svarīgākos produktus uzṇēma līdzīgi, var domāt par D vitamīna metabolisma īpatnībām PV pacientiem. Par labu šai hipotēzei liecina arī dati, ka D vitamīns uzturā kontroles grupā korelēja ar D vitamīna seruma koncentrāciju, bet nekorelēja PV grupā. Līdz ar to zemā D vitamīna koncentrācija serumā varētu būt skaidrojama gan ar nepietiekamo saules ekspozīciju, gan nepietiekamo D vitamīna daudzumu uzturā.

Daļa pētījumu rāda, ka lielāks vecums ir saistīts ar zemāku D vitamīna koncentrāciju [Trump, 2009]. Mūsu pētījumā kontroles grupas dalībniekiem, pieaugot vecumam, palielinājās D vitamīna seruma koncentrācija, kas, iespējams, saistīts ar to, ka kontroles grupas vīrieši vairāk uzturējušies ārpus telpām, kaut arī fiziskā aktivitāte tiem bijusi mazāka nekā PV pacientiem. Literatūrā ir norādījumi, ka, palielinoties ĶMI, D vitamīna koncentrācija pazeminās [Ahn, 2008], pētījumā ar Latvijas sievietēm šāda saistība tika konstatēta vasarā, bet ne ziemā [Lejnieks, 2013]. Mēs nekonstatējām saistību starp D vitamīna seruma koncentrāciju un ĶMI, ko var izskaidrot ar to, ka lielākajai daḷai mūsu pētījuma dalībnieku bija palielināts svars vai aptaukošanās 1. pakāpe.

Pētot D vitamīnu, mūsu pētījuma stiprās puses bija stingrie pacientu atlases kritēriji, homogēna pētījuma dalībnieku grupa, detalizēta informācija par uzņemto uzturu, dzīvesveida faktoriem un demogrāfiskajiem rādītājiem. Pētījuma ierobežojumi bija mazais PV pacientu skaits.

Kopsavilkumā: D vitamīna deficīts un/vai nepietiekamība ir plaši izplatīta PV grupas un kontroles grupas vīriešiem. Ar uzturu netiek nodrošināts nepieciešamais D vitamīna daudzums. Lai izvērtētu D vitamīna iespējamo protektīvo efektu PV prevencijā, ieteicams lietot $\mathrm{D}$ vitamīna neaktīvās formas preparātus, lai sasniegtu vēlamo D vitamīna seruma koncentrāciju un veiktu prospektīvus pētījumus. 


\section{SECINĀJUMI}

1. Lignānu koncentrācija sēklu un rudzu maizē Latvijas un Somijas maizē ir līdzvērtīga. Alkilrezorcīnu koncentrācija Latvijas rudzu maizē ir tikpat augsta kā Skandināvijas un Polijas rudzu maizē. Alkilrezorcīnu daudzumu maizē var izmantot par marķieri kliju un šķiedrvielu daudzumam maizē.

2. Izveidotā uztura aptaujas anketa kopā ar papildināto BIOR pārtikas produktu datu bāzi ir piemērota, lai veiktu pētījumus par pilngraudu produktiem uzturā.

3. Galvenie lignānu avoti uzturā abām grupām ir sēklu un rudzu maize. Netika konstatētas statistiski ticamas atšķirības priekšdziedzera vēža un kontroles grupā uzṇemto uzturvielu, tostarp alkilrezorcīnu un lignānu, daudzumā.

4. AR metabolīts DHPPA $12 \mathrm{~h}$ nakts urīnā ir piemērotākais biomarķieris rudzu maizes un rudzu šķiedrvielu daudzuma novērtēšanai uzturā.

5. Alkilrezorcīnu metabolītu plazmā un urīnā izmeklējumu rezultāti norāda uz kavētu AR metabolismu PV pacientiem.

6. ENL koncentrācija biologiskajos şķidrumos atspoguḷo lignānu daudzumu uzturā tikai intervences pētījuma apstākḷos. Antibiotiku iedarbība uz ENL koncentrāciju bioloǵiskajos šķidrumos ir atšķirīga PV un kontroles grupā, kas norāda uz potenciālām zarnu mikrofloras atšķirībām PV un kontroles grupās. Šis rezultāts prasa padziḷinātu izpēti.

7. Pilngraudu rudzu maize, iespējams, kavē PV progresēšanu.

8. D vitamīna deficīts un/vai nepietiekamība ir plaši izplatīta gan PV grupā, gan kontroles grupas vīriešiem pēc 45 gadu vecuma. Ar ikdienas uzturu D vitamīnu uzn,em nepietiekami. 


\section{PRAKTISKĀS REKOMENDĀCIJAS UN IEVIEŠANA}

1. DHPPA $12 \mathrm{~h}$ nakts urīnā ir izmantojams epidemiologiskajos pētījumos kā biomarķieris rudzu maizes un rudzu šķiedrvielu daudzumam uzturā.

2. Intervences pētîjumos, lai izvērtētu rudzu graudu ietekmi uz PV progresēšanu, izmantot rudzu maizi ar lielāku rudzu šķiedrvielu daudzumu - rudzu maizi ar pievienotām rudzu klijām.

3. Uzturā izvēlēties pilngraudu rudzu un sēklu-kliju maizi, jo tā satur daudz biologiski aktīvu vielu. Maizes cepšanai lielražošanā jāizmanto pilngraudu milti. Ir jāveicina patērētāju pieprasījums pēc pilngraudu maizes. Sabiedrības izglītošanā jāsadarbojas uzturzinātniekiem, uztura speciālistiem, pārtikas tehnologiem, graudu selekcionāriem, izglītības darbiniekiem un plašsaziņas līdzekḷiem.

4. Regulāri lietot D vitamīna neaktīvo formu preparātu veidā1000 SV, kā arī ikdienas uzturā vairāk lietot $\mathrm{D}$ vitamīnu saturošus produktus, no kuriem visnozīmīgākais ir zivis. 


\section{PATEICĪBAS}

Vēlos pateikties mana promocijas darba vadītājiem: asoc. prof. Vilnim Lietuvietim, kas ieinteresēja mani zinātniskajā darbā un aizrāva ar ideju, ka priekšdziedzera vēzi var ietekmēt ar uzturu, kā arī pētnieciskajā procesā iesaistīja Urologijas klīniku; un milzīgs paldies prof. Aivaram Lejniekam par atbalstu un vērtīgajiem, strukturētajiem un augsti profesionālajiem padomiem promocijas darba tapšanas laikā. Īpašs paldies emer. prof. Hermanim Adlerkreicam (Herman Adlercreutz), kas aizrāva ar idejām par pilngraudu un fitoestrogēnu protektīvo lomu un palīdzēja izveidot pētījuma dizainu, piedalījās publikāciju tapšanā, vienmēr bija atsaucīgs un nodrošināja izmeklējumu veikšanu Helsinku Universitātes Preventīvās medicīnas, uztura un vēža institūta Biomedicum laboratorijā, kur laipni piedalījās Anja Koskela (Anja Koskela) un Adile Samaletdina (Adile Samaletdin), kā arī Peivi Sēderholma (Päivi Söderholm), kas palīdzēja ar padomiem par uztura datu iegūšanu.

Pētījumu nevarētu realizēt, ja nebūtu atbalsta no atsaucīgiem cilvēkiem visapkārt. Paldies NMS laboratorijai ar Dainu Sinkēviču un Zeltīti Rūsu priekšgalā un RSU Bioķīmijas laboratorijai ar aizrautīgo vadītāju Andreju Šksesteri un ārkārtīgi atsaucīgajām un profesionālajām darbiniecēm Līgu Lārmani un Alisi Silovu. Paldies ǵimenes ārstēm Irēnai Salgus un Lailai Mikulei ar medicīnas māsām par atbalstu, pētījuma sākuma posmā iesaistot pētījuma dalībniekus, institūtam BIOR un personīgi Rafaelam Joffem un Inesei Siksnai par atsaucību, patologam Mārim Spergam par atbalstu risinot morfoloǵijas jautājumus un Dainai Erdmanei par milzīgo darbu, aptaujājot pacientus un nodrošinot analīžu veikšanu un nogādāšanu uz laboratoriju. Par uztura datu apstrādi paldies Andaram Ignacam un īpaša pateicība Vinitai Caucei, kura vieglprātīgi l̦āva sevi ievilkt uztura datu apstrādes okeānā, kas ievērojami atšḳiras no rutīnas biostatistikas, un ar kuru mēs joprojām kopā peldam.

Pateicos doc. Zigurdam Zariṇam par piesaistīšanu dietolog̣ijai, prof. Idai Jākobsonei par atbalstu visās situācijās un ticību uzturzinātnes nākotnei Latvijā. Neatsveramu profesionālo atbalstu publikāciju gatavošanā esmu saṇēmusi no prof. Indriķa Krama, kura personība iedvesmo zinātnei. Paldies maizes ekspertei Daigai Kunkulbergai un atsaucīgajiem Valsts Stendes graudaugu selekcijas institūta darbiniekiem, īpaši - Sanitai Zutei, par konsultācijām jebkurā laikā. Par palīdzību latviešu valodas uzlabošanā sirsnīgs paldies Ievai Miķelsonei un Kamenai Kaidakai. 
Par finansiālo atbalstu paldies Roche Akadēmijai, Latvijas Ārstu biedrībai un GlaxoSmithKline fondam „Medicīnas izglīitības un zinātnes atbalstam”.

Vismīịākais paldies visai manai ǵimenei par sapratni un ticību maniem spēkiem. Īpaša pateicība par izturību manam vīram, kurš darba izstrādāšanas periodā tika ļoti pietuvināts zinātnei un tās problēmām, manai mammai par mīlestību un sapratni un dēlam par palīdzību. Paldies draugiem par morālo atbalstu, pacietību un to, ka viņi joprojām palikuši mani draugi. 


\section{IZMANTOTĀ LITERATŪRA}

1. Adlercreutz H., Fotsis T., Hockerstedt K., Hamalainen E., et al. Diet and urinary estrogen profile in premenopausal omnivorous and vegetarian women and in premenopausal women with breast cancer // Journal of Steroid Biochemistry, 1989a; 34(1-6): 527-530.

2. Adlercreutz H., Hamalainen E., Gorbach S.L., Goldin B.R., et al. Diet and plasma androgens in postmenopausal vegetarian and omnivorous women and postmenopausal women with breast cancer // The American Journal of Clinical Nutrition, 1989b; 49(3): 433-442.

3. Adlercreutz H., Wang G.J., Lapcik O., et al. Time-resolved fluoroimmunoassay for plasma enterolactone // Analytical Biochemistry, 1998; 265(2): 208-215.

4. Adlercreutz H. Phyto-oestrogens and cancer // The Lancet Oncology, 2002; 6: 364-373.

5. Adlercreutz H. Lignans and human health // Critical Reviews in Clinical Laboratory Sciences, 2007; 5-6: 483-525.

6. Adlercreutz H. Can rye intake decrease risk of human breast cancer?// Food \& Nutrition Research, 2010, 10: 1-9.

7. Ahn J., Peters U., Albanes D., et al. Serum Vitamin D Concentration and Prostate Cancer Risk: A Nested Case-Control Study // Journal of the National Cancer Institute, 2008; 100: 796-804.

8. Ahonen M.H., Tenkanen L., Teppo L., Hakama M., et al. Prostate cancer risk and prediagnostic serum 25-hydroxyvitamin D levels (Finland) // Cancer Causes Control, 2000; 11(9): 847-852.

9. Alexander D.D., Mink P.J., Cushing C.A., Sceurman B. A review and meta-analysis of prospective studies of red and processed meat intake and prostate cancer // Journal of Nutrition, 2010; 2: 50.

10. American Cancer Society. What are the risk factors for prostate cancer? 2012. // http://www.cancer.org/cancer/prostatecancer/detailedguide/prostate-cancer-risk-factors.(sk. 05.09.2013).

11. Andersson A.A.M., Aman P., Wandel M., Frolich W. Alkylresorcinols in wheat and rye flour and bread // Journal of Food Composition and Analysis, 2010; 23(8): 794-801.

12. Anderson J.W., Baird P., Davis R.H. Jr., Ferreri S., et al. Health benefits of dietary fiber // Nutrition Reviews, 2009; 67(4): 188-205.

13. Arlen P.M., Bianco F., Dahut W.L., D’Amico A., et al. Prostate Specific Antigen Working Group guidelines on prostate specific antigen doubling time // Journal of Urology, 2008; 179(6): 21812185.

14. Astorg P. Dietary N-6 and N-3 polyunsaturated fatty acids and prostate cancer risk: a review of epidemiological and experimental evidence // Cancer Causes Control, 2004; 15(4): 367-386.

15. Aubertin-Leheudre M., Gorbach S., Woods M., et al. Fat/fiber intakes and sex hormones in healthy premenopausal women in USA // The Journal of Steroid Biochemistry and Molecular Biology, 2008a; 112(1-3): 32-39.

16. Aubertin-Leheudre M., Koskela A., Marjamaa A., Adlercreutz H. Plasma alkylresorcinols and urinary alkylresorcinol metabolites as biomarkers of cereal fiber intake in Finnish women // Cancer Epidemiology, Biomarkers \& Prevention, 2008b; 17(9): 2244-2248.

17. Aubertin-Leheudre M., Koskela A., Samaletdin A., Adlercreutz H. Plasma and urinary alkylresorcinol metabolites as potential biomarkers of breast cancer risk in Finnish women: a pilot study // Nutrition and Cancer, 2010a, 62(6): 759-764.

18. Aubertin-Leheudre M., Koskela A., Samaletdin A., Adlercreutz H. Plasma alkylresorcinol metabolites as potential biomarkers of whole-grain wheat and rye cereal fibre intakes in women // British Journal of Nutrition, 2010b; 103(3): 339-343.

19. Bacciottini L., Falchetti A., Pampaloni B., Bartolini E., et al. Phytoestrogens: food or drug? // Clinical Cases in Mineral and Bone Metabolism, 2007; 4(2):123-30. 
20. Barnett C.M., Nielson C.M., Shannon J., Chan J.M., et al. Serum 25-OH vitamin D levels and risk of developing prostate cancer in older men // Cancer Causes Control, 2010; 21(8): 1297-1303.

21. Beebe-Dimmer J.L., Faeber G.J., Morgenstern H., Werny D., et al. Body composition and serum prostate-specific antigen: review and findings from Flint Men's Health Study // Urology, 2008; 71(4): 554-560.

22. Bennets H.W., Underwod E.J,. Shier F.L. A specific breeding problem of sheep on subterranean clover pastures in Western Australia // Australian Veterinary Journal, 1946; 2-12.

23. Blackburn E.H. Highlighting the science of cancer prevention // Cancer Prevention Research (Phila), 2010; 3(4): 393.

24. Boker L.K., Van der Schouw Y.T., De Kleijn M.J., Jacques P.F., et al. Intake of dietary phytoestrogens by Dutch women // Journal of Nutrition, 2002; 132: 1319-1328.

25. Bosetti C., Bertuccio P., Chatenoud L., Negri E., et al. Trends in mortality from urologic cancers in Europe // European Urology, 2011; 60(1): 1-15.

26. Bosetti C., Filomeno M., Riso P., Polesel J., et al. Cruciferous vegetables and cancer risk in a network of case-control studies // Annals of Oncology, 2012; 23(8): 2198-2203.

27. Bostwick D.G., Burke H.B., Djakiew D., Euling S., et al. Human prostate cancer risk factors // Cancer, 2004; 101(10): 2371-2490.

28. Brouwer A., Longnecker M.P., Birnbaum L.S., Cogliano J., et al. Characterization of potential endocrine-related health effects at low-dose levels of exposure to PCBs // Environmental Health Perspectives, 1999; 107(4): 639-649.

29. Buschemeyer W.C. 3rd., Freeland S.J. Obesity and prostate cancer: epidemiology and clinical implications // European Urology, 2007; 52(2): 331-343.

30. Bylund A., Zhang J.X., Bergh A., Damber J.E., et al. Rye bran and soy protein delay growth and increase apoptosis of human LNCaP prostate adenocarcinoma in nude mice // Prostate, 2000; 42(4): 304-314.

31. Bylund A., Lundin E., Zhang J.X., Nordin A., et al. Randomised controlled short-term intervention pilot study on rye bran bread in prostate cancer // European Journal of Cancer Prevention, 2003; 12(5): 407-415.

32. Carmichael S.L., Gonzalez-Feliciano A.G., Ma C., Shaw G.M., et al. Estimated dietary phytoestrogen intake and major food sources among women during the year before pregnancy // Journal of Nutrition, 2011; 6:105.

33. Chan J.M., Gann P.H., Giovannucci E.L. Role of diet in prostate cancer development and progression // Journal of Clinical Oncology, 2005; 23(32): 8152-8160.

34. Chan R., Lok K., Woo J. Prostate cancer and vegetable consumption // Molecular Nutrition \& Food Research, 2009; 52(2): 201-216.

35. Cheetham P.J., Katz A.E. Diet and prostate cancer - a holistic approach to management // Archivos Españoles de Urología, 2011; 64(8): 720-734

36. Chen Y., Ross A.B., Aman P., Kamal-Eldin A. Alkylresorcinols as markers of whole grain wheat and rye in cereal products // Journal of Agricultural and Food Chemistry, 2004; 52(26): 8242-8246.

37. Clavel T., Dore J., Blaut M. Bioavailability of lignans in human subjects // Nutrition Research Reviews, 2006a; 19(2): 187-196.

38. Clavel T., Borrmann D., Braune A., Dore J., et al. Occurrence and activity of human intestinal bacteria involved in the conversion of dietary lignans // Anaerobe, 2006b; 3: 140-147.

39. Colli J.L., Grant W.B. Solar ultraviolet B radiation compared with prostate cancer incidence and mortality rates in United States // Urology, 2008; 71(3): 531-535.

40. Committee on Toxicity of Chemicals in Food, Consumer Products and the Environment. Phytoestrogens and Health // http://cot.food.gov.uk/pdfs/phytoreport0503 (sk. 15.05.2013).

41. Cornwell T., Cohick W., Raskin I. Dietary phytoestrogens and health // Phytochemistry; 2004; 65(8): 995-1016. 
42. Cotterchio M., Boucher B.A., Kreiger N., Mills C.A., et al. Dietary phytoestrogen intake--lignans and isoflavones--and breast cancer risk (Canada) // Cancer Causes Control, 2008; 3:259-272.

43. Cross H.S., Kallay E., Lechner D., Gerdenitsch W., et al. Phytoestrogens and vitamin D metabolism: a new concept for the prevention and therapy of colorectal, prostate, and mammary carcinomas // Journal of Nutrition, 2004; 134(5): 1207-1212.

44. Deep K.K., Trump D.L., Johnson C.S. Vitamin D signalling pathways in cancer: potential for anticancer therapeutics // Nature Reviews Cancer, 2007; 7(9): 684-700.

45. De Kleijn M.J., Van der Schouw Y.T., Wilson P.W., Adlercreutz H., et al. Intake of dietary phytoestrogens is low in postmenopausal women in the United States: the Framingham study(1-4) // Journal of Nutrition, 2001; 6:1826-1832.

46. Demark-Wahnefried W., Price D.T., Polascik T.J., Robertson C.N., et al. Pilot study of dietary fat restriction and flaxseed supplementation in men with prostate cancer before surgery: exploring the effects on hormonal levels, prostate-specific antigen, and histopathologic features // Urology, 2001; 58(1): 47-52.

47. De la Taille, A., Katz A., Vacherot F., Saint F., et al. Cancer of the prostate: influence of nutritional factors. General nutritional factors // La Presse Médicale, 2001; 30(11): 554-556.

48. Demark-Wahnefried W., Robertson C.N., Walther P.J., Polascik T.J.,et al. Pilot study to explore effects of low-fat, flaxseed-supplemented diet on proliferation of benign prostatic epithelium and prostate-specific antigen // Urology, 2004; 63(5): 900-904.

49. Demark-Wahnefried W., Polascik T.J., George S.L., Switzer B.R., et al. Flaxseed supplementation (not dietary fat restriction) reduces prostate cancer proliferation rates in men presurgery // Cancer Epidemiology, Biomarkers \& Prevention, 2008; 17(12): 3577-3587.

50. De Munter, J.S., Hu F.B., Spiegelman D., Franz M., et al. Whole grain, bran, and germ intake and risk of type 2 diabetes: a prospective cohort study and systematic review // PLOS Medicine, 2007; 4(8): 261

51. Donkena K.V., Young C.Y. Vitamin d, sunlight and prostate cancer risk // Advanced Preventive Medicine, 2011; 281863.

52. Egeberg R., Olsen A., Christensen J., Johnsen N.F., et al. Intake of whole-grain products and risk of prostate cancer among men in the Danish Diet, Cancer and Health cohort study // Cancer Causes Control, 2011; 22(8): 1133-1139.

53. European Food Safety Authority:Scientific Committee on Food. Scientific Panel on Dietetic Products, Nutrition and Allergies Tolerable upper intake levels for vitamins and minerals // http://www.efsa.europa.eu/en/ndatopics/docs/ndatolerableuil.pdf (sk. 08.01.2013.).

54. FAOSTAT. (2007). Food consumption quantity (kg/capita/yr) // http://faostat.fao.org/site/609/default.aspx\#ancor (sk. 29.04.2012.).

55. Farhan H., Wahala K., Adlercreutz H., Cross H.S. Isoflavonoids inhibit catabolism of vitamin D in prostate cancer cells // Journal of Chromatography B, 2002; 777(1-2): 261-268.

56. Faupel-Badger J.M., Diaw L., Albanes D., Virtamo J., et al. Lack of association between serum levels of 25-hydroxyvitamin D and the subsequent risk of prostate cancer in Finnish men, 2007; 16(12): 2784-2786

57. Flight I., Clifton P. Cereal grains and legumes in the prevention of coronary heart disease and stroke: a review of the literature // European Journal of Clinical Nutrition. 2006; 60: 1145-1159.

58. Gandini S., Boniol M., Haukka J., Byrnes G., et al. Meta-analysis of observational studies of serum 25-hydroxyvitamin D levels and colorectal, breast and prostate cancer and colorectal adenoma // International Journal of Cancer, 2011; 126(6): 1414-1424.

59. Gao X., LaValley M.P., Tucker K.L. Prospective studies of dairy product and calcium intakes and prostate cancer risk: a meta-analysis // Journal of the National Cancer Institute, 2005; 97(23): 17681777. 
60. Gilbert R., Metcalfe C., Oliver S.E., Whiteman D.C., et al. Life course sun exposure and risk of prostate cancer: population-based nested case-control study and meta-analysis // International Journal of Cancer, 2009; 125(6): 1414-1423.

61. Gilbert R., Martin R.M., Beynon R., Savovic J., et al. Associations of circulating and dietary vitamin D with prostate cancer risk: a systematic review and dose-response meta-analysis // Cancer Causes Control, 2011; 22(3): 319-340.

62. Gilbert R., Metcalfe C., Fraser W.D., Donovan J., et al. Associations of circulating 25hydroxyvitamin D with prostate cancer diagnosis, stage and grade // International Journal of Cancer, 2012; 131(5): 1187-1196.

63. Giovannucci E., Ascherio A., Rimm E.B., Stampfer M.J., et al. Intake of carotenoids and retinol in relation to risk of prostate cancer // Journal of the National Cancer Institute, 1995; 87(23): 17671776.

64. Giovannucci E., Rimm E.B., Liu Y., Stampfer M.J., et al. A prospective study of tomato products, lycopene, and prostate cancer risk // Journal of the National Cancer Institute, 2002; 94(5): 391-398.

65. Giovannucci E., Rimm E.B., Liu Y.., Stampfer M.J., et al. A prospective study of cruciferous vegetables and prostate cancer // Cancer Epidemiology, Biomarkers \& Prevention, 2003; 12(12): 1403-1409.

66. Giri, D., Ozen M., Ittmann M. Interleukin-6 is an autocrine growth factor in human prostate cancer // American Journal of Pathology, 2001; 159(6): 2159-2165.

67. Gonzalez C.A., Riboli E. Diet and cancer prevention: Contributions from the European Prospective Investigation into Cancer and Nutrition (EPIC) study // Diet and cancer prevention: Contributions from the European Prospective Investigation into Cancer and Nutrition (EPIC) study, 2010; 46(14): 2555-2562.

68. Grossmann M., Zajac J.D. Management of side effects of androgen deprivation therapy // Endocrinology and Metabolism Clinics of North America, 2011; 40(3): 655-671.

69. Grossmann M., Wittert G. Androgens, diabetes and prostate cancer // Endocrine-Related Cancer, 2012; 19: 47-62.

70. Grubb R.L. 3rd., Black A., Izmirlian G., Hickey T.P., et al. Serum prostate-specific antigen hemodilution among obese men undergoing screening in the Prostate, Lung, Colorectal, and Ovarian Cancer Screening Trial // Cancer Epidemiology, Biomarkers \& Prevention, 2009; 18(3): 748-751.

71. Guyman L.A., Adlercreutz H., Koskela A., Li L., Beresford S.A., et al. Urinary 3-(3,5dihydroxyphenyl)-1-propanoic acid, an alkylresorcinol metabolite, is a potential biomarker of whole-grain intake in a U.S. population // Journal of Nutrition, 2008; 138(10): 1957-1962.

72. Hammarsten J., Hogstedt B. Hyperinsulinaemia: a prospective risk factor for lethal clinical prostate cancer // European Journal of Cancer, 2005; 41(18): 2887-2895.

73. Heald C.L., Ritchie M.R., Bolton-Smith C., Morton M.S, et al. Phyto-oestrogens and risk of prostate cancer in Scottish men // British Journal of Nutrition, 2007; 98(2): 388-396.

74. Healthgrain Consortium. Whole grain definition, 2010 // http://www.healthgrain.org (sk. 05.16.2013.).

75. Hedelin M., Klint A., Chang E.T., Bellocco R., et al. Dietary phytoestrogen, serum enterolactone and risk of prostate cancer: the cancer prostate Sweden study (Sweden) // Cancer Causes Control, 2006; 17: 169-180.

76. Hedelin M., Lof M., Olsson M., Adlercreutz H., et al. Dietary phytoestrogens are not associated with risk of overall breast cancer but diets rich in coumestrol are inversely associated with risk of estrogen receptor and progesterone receptor negative breast tumors in Swedish women // Journal of Nutrition, 2008; 138(5): 938-945.

77. Heidenreich A., Bellmunt J., Bolla M., Joniau S., et al. EAU guidelines on prostate cancer. Part I: screening, diagnosis, and treatment of clinically localised disease // Actas Urologicas Espanola, 2011; 35(9): 501-514. 
78. Heinonen S., Nurmi T., Liukkonen K., Poutanen K., et al. In vitro metabolism of plant lignans: new precursors of mammalian lignans enterolactone and enterodiol // Journal of Agricultural and Food Chemistry, 2001; 7(49): 3178-3186.

79. Higdon J.V., Delage B., Williams D.E., Dashwood R.H. Cruciferous vegetables and human cancer risk: epidemiologic evidence and mechanistic basis // Pharmacological Research, 2007; 55(3): 224-236.

80. Ho C.K., Habib F.K. Estrogen and androgen signaling in the pathogenesis of BPH // Nature Reviews Urology, 2011; 8(1): 29-41.

81. Hoda, M.R., Mohammed N., Theil G., Fischer K., et al. Obesity and prostate cancer : Role of adipocytokines and clinical implications // Urologe A, 2012; 51(9): 1253-1260.

82. Holick M.F. Vitamin D deficiency // The New England Journal of Medicine, 2007; 357(3): 266-281.

83. Holick M.F., Binkley N.C., Bischoff-Ferrari H.A., Gordon C.M., et al. Evaluation, treatment, and prevention of vitamin D deficiency: an Endocrine Society clinical practice guideline // The Journal of Clinical Endocrinology \& Metabolism, 2011; 96(7): 1911-1930.

84. Horner N.K., Lampe J.W. Potential mechanisms of diet therapy for fibrocystic breast conditions show inadequate evidence of effectiveness // Journal of the American Dietetic Association, 2000; 100(11): 1368-1380.

85. Horn-Ross P.L., Barnes S., Lee M., Coward L., et al. Assessing phytoestrogen exposure in epidemiologic studies: development of a database (United States) // Cancer Causes \& Control, 2000a; 11: 289-298.

86. Horn-Ross P.L., Lee M., John E.M., Koo J., Sources of phytoestrogen exposure among non-Asian women in California, USA // Cancer Causes Control, 2000b; 4: 299-302.

87. Hsieh L.J., Carter H.B., Landis P.K., Tucker K.L., et al. Association of energy intake with prostate cancer in a long-term aging study: Baltimore Longitudinal Study of Aging (United States) // Urology, 2003; 61(2): 297-301.

88. Hu G.X., Chen G.R., Xu H., Ge R.S., et al. Activation of the AMP activated protein kinase by shortchain fatty acids is the main mechanism underlying the beneficial effect of a high fiber diet on the metabolic syndrome // Medical Hypotheses, 2010; 74(1): 123-126.

89. Huncharek M., Muscat J., Kupelnick B. Dairy products, dietary calcium and vitamin D intake as risk factors for prostate cancer: a meta-analysis of 26,769 cases from 45 observational studies // Nutrition and Cancer, 2008a; 60(4): 421-441.

90. Huncharek S., Linseisen J., Key T.J., Jensen M.K., et al. Alcohol consumption and the risk for prostate cancer in the European Prospective Investigation into Cancer and Nutrition // Cancer Epidemiology, Biomarkers \& Prevention, 2008b; 17(5): 1282-1287.

91. Huncharek M., Haddock K.S., Reid R., Kupelnick B. Smoking as a risk factor for prostate cancer: a meta-analysis of 24 prospective cohort studies // American Journal of Public Health, 2010; 100(4): 693-701.

92. International Agency for Research on Cancer. Prostate Cancer Incidence and Mortality Worldwide in 2008: Globocan 2008 // http://globocan.iarc.fr/factsheets/cancers/prostate.asp (sk. 10.06.2013.).

93. Jackson C.L., Dreaden T.M., Theobald L.K., Tran N.M., et al. Pectin induces apoptosis in human prostate cancer cells: correlation of apoptotic function with pectin structure // Glycobiology, 2007; 17(8): 805-819.

94. Jan K.C., Ho C.T., Hwang L.S. Elimination and metabolism of sesamol, a bioactive compound in sesame oil, in rats // Molecular Nutrition \& Food Research, 2009; 53(1): 36-43.

95. Jansen G.H., Arts I.C., Nielen M.W., Muller M., et al. Uptake and metabolism of enterolactone and enterodiol by human colon epithelial cells // Archives of Biochemistry and Biophysics, 2005; 435(1): 74-82.

96. Jansson E., Landberg R., Kamal-Eldin A., Wolk A., Vessby B., et al. Presence of alkylresorcinols, potential whole grain biomarkers, in human adipose tissue // British Journal of Nutrition, 2010; 104(5): 633-636. 
97. Jenab M., Slimani N., Bitctash M., Ferrari P., et al. Biomarkers in nutritional epidemiology: applications, needs and new horizonts // Human Genetics, 2009; 5-6: 507-525.

98. Jian L. Soy, isoflavones, and prostate cancer // Molecular Nutrition \& Food Research, 2009; 53(2): 217-226.

99. John E.M., Dreon D.M., Koo J., Schwartz G.G. Residential sunlight exposure is associated with a decreased risk of prostate cancer // The Journal of Steroid Biochemistry and Molecular Biology, 2004; 89-90(1-5): 549-552.

100. Kamal-Eldin A., Lærke H.N., Knudsen K.E., Lampi A.M., et al. Physical, microscopic and chemical characterisation of industrial rye and wheat brans from the Nordic countries // Food \& Nutrition Research, 2009; 53.

101. Karlsson S., Olausson J., Lundh D., Sogard P., et al. Vitamin D and prostate cancer: the role of membrane initiated signaling pathways in prostate cancer progression // The Journal of Steroid Biochemistry and Molecular Biology, 2010; 121(1-2): 413-416.

102. Kasper J.S., Giovannuci E. A meta-analysis of diabetes mellitus and the risk of prostate cancer // Cancer Epidemiology, Biomarkers \& Prevention, 2006; 15(11): 2056-2062.

103. Key T.J., Appleby P.N., Allen N.E., Travis R.C., et al. Plasma carotenoids, retinol, and tocopherols and the risk of prostate cancer in the European Prospective Investigation into Cancer and Nutrition study // The American Journal of Clinical Nutrition, 2007; 86(3): 672-681.

104. Khan N., Adhami V.M., Mukhtar H. Apoptosis by dietary agents for prevention and treatment of prostate cancer // Endocrine-Related Cancer, 2010; 17(1): 39-52.

105. Kilkkinen A., Stumpf K., Pietinen P., Valsta L.M., et al. Determinants of serum enterolactone concentration // The American Journal of Clinical Nutrition, 2001; 73(6): 1094-1100.

106. Kilkkinen A., Valsta L.M., Virtamo J., Stumpf K., et al. Intake of lignans is associated with serum enterolactone concentration in Finnish men and women // Journal of Nutrition, 2003a; 133: 18301833.

107. Kilkkinen A., Virtamo J., Virtanen M.J., Adlercreutz H., et al. Serum enterolactone concentration is not associated with prostate cancer risk in a nested case-control study // Cancer Epidemiology, Biomarkers \& Prevention, 2003b; 12(11): 1209-1212.

108. Kim H.S., Bowen P., Chen L., Duncan C., et al. Effects of tomato sauce consumption on apoptotic cell death in prostate benign hyperplasia and carcinoma // Nutrition and Cancer, 2003; 47(1): 4047.

109. Kiple K.F., Ornelas K.C. The Cambridge World History of Food. - Cambridge: Cambridge University Press, 2000. - Pp. 1086.-1097.

110. Kirsh V.A., Peters U., Mayne S.T., Subar A.F., et al. Prospective study of fruit and vegetable intake and risk of prostate cancer // Journal of the National Cancer Institute, 2007; 99(15): 1200-1209.

111. Knight D.C., Eden J.A. A review of the clinical effects of phytoestrogens // Obstetrics \& Gynecology, 1996; 87(5 Pt 2): 897-904.

112. Koskela A., Linko-Parvinen A.M., Hiisivuori P., Samaletdin A., et al. Quantification of alkylresorcinol metabolites in urine by HPLC with coulometric electrode array detection // Clinical Chemistry, 2007; 53(7): 1380-1383.

113. Koskela A., Samaletdin A., Aubertin-Leheudre M., Adlercreutz H. Quantification of alkylresorcinol metabolites in plasma by high-performance liquid chromatography with coulometric electrode array detection // Journal of Agricultural and Food Chemistry, 2008; 56: 7678-7681.

114. Kozubek A., Nienartowicz B. Cereal grain resorcinolic lipids inhibit $\mathrm{H} 2 \mathrm{O} 2$-induced peroxidation of biological membranes // Acta Biochimica Polonica, 1995; 42(3): 309-315.

115. Krishnan A.V., Feldman D. Molecular pathways mediating the anti-inflammatory effects of calcitriol: implications for prostate cancer chemoprevention and treatment // Endocrine-Related Cancer, 2010; 17(1): 19-38. 
116. Kristal A.R., Arnold K.B., Neuhouser M.L., Goodman P., et al. Diet, supplement use, and prostate cancer risk: results from the prostate cancer prevention trial // American Journal of Epidemiology, 2010; 172(5): 566-577.

117. Kuhnle G.G., Dell'Aquila C., Aspinall S.M., Runswick S.A., et al. Phytoestrogen content of foods of animal origin: dairy products, eggs, meat, fish, and seafood // Journal of Agricultural and Food Chemistry, 2008a; 56: 10099-10104.

118. Kuhnle G.G.C. Dietary and biomarker prospective study of phytoestrogens in breast and prostate cancer : final report // London: Food Standards Agency, 2008b.

119. Kuijsten A., Arts I.C., Vree T.B., Hollman P.C. Pharmacokinetics of enterolignans in healthy men and women consuming a single dose of secoisolariciresinol diglucoside // Journal of Nutrition, 2005a, 135(4): 795-801.

120. Kuisten A., Arts I.C., Van't Veer P., Hollman P.C. The relative bioavailability of enterolignans in humans is enhanced by milling and crushing of flaxseed // Journal of Nutrition, 2005b; 12: 2812-2816.

121. Kukulis I., Lietuvietis V., Vaganovs P., Jakubovskis M., u.c. Prostate cancer in Latvia. Population based study // European Urology Supplements, 2011; 9(6): 535.

122. Kulawinek M., Jaromin A., Kozubek A., Zarnowski R. Alkylresorcinols in selected Polish rye and wheat cereals and whole-grain cereal products // Journal of Agricultural and food Chemistry, 2008; 56(16): 7236-7242.

123. Laaksonen D.E., Laukanen J.A., Niskanen L., Nyyssonen K., et al. Serum linoleic and total polyunsaturated fatty acids in relation to prostate and other cancers: a population-based cohort study // International Journal of Cancer, 2004; 111(3): 444-450.

124. Lagunova D., Luscombe C.J., French M.E., Liu S., et al. Susceptibility to prostate cancer: studies on interactions between UVR exposure and skin type // Carcinogenesis, 2003; 24(4): 711-717.

125. Lagunova Z., Porojnicu A.C., Dahlback A., Berg J.P., et al. Prostate cancer survival is dependent on season of diagnosis // Prostate, 2007; 67(12): 1362-1370.

126. Lampe J. W. Isoflavonoid and lignan phytoestrogens as dietary biomarkers // Journal of Nutrition, 2003; 133(3): 956-964.

127. Lampe J.W., Dairy products and cancer // The Journal of the American College of Nutrition, 2011; 30: 464-470.

128. Landberg R., Kamal-Eldin A., Andersson R., Aman P. Alkylresorcinol content and homologue composition in durum wheat (Triticum durum) kernels and pasta products // Journal of Agricultural and Food Chemistry, 2006; 54(8): 3012-3014.

129. Landberg R., Kamal-Eldin A., Salmenkallio-Marttila M., Rouau X., et al. Localization of alkylresorcinols in wheat, rye and barley kernels // Journal of Cereal Science, 2008a; 48(2): 401-406.

130. Landberg R., Kamal-Eldin A., Andersson A., Vessby B., Aman P. Alkylresorcinols as biomarkers of whole-grain wheat and rye intake: plasma concentration and intake estimated from dietary records // The American Journal of Clinical Nutrition, 2008b; 87(4): 832-838.

131. Landberg R, Aman P., Friberg L.E., Vessby B., et al. Dose response of whole-grain biomarkers: alkylresorcinols in human plasma and their metabolites in urine in relation to intake // The American Journal of Clinical Nutrition, 2009a; 89(1): 290-296.

132. Landberg R., Kamal-Eldin A., Andersson S.O., Johansson J.E., et al. Reproducibility of plasma alkylresorcinols during a 6-week rye intervention study in men with prostate cancer // Journal of Nutrition, 2009b; 139(5): 975-980.

133. Landberg R., Amdersson S.O., Zhang J.X., Johansson J.E., et al. Rye whole grain and bran intake compared with refined wheat decreases urinary C-peptide, plasma insulin, and prostate specific antigen in men with prostate can // Journal of Nutrition, 2010; 140(12): 2180-2186. 
134. Landberg R., Kamal-Eldin A., Aman P., Christensen J., et al. Determinants of plasma alkylresorcinol concentration in Danish post-menopausal women // European Journal of Clinical Nutrition, 2011; 65(1): 94-101.

135. Landstrom M., Zhang J.X., Hallmans G., Aman P., et al. Inhibitory effects of soy and rye diets on the development of Dunning R3327 prostate adenocarcinoma in rats // Prostate, 1998; 36(3): 151 161.

136. Lang R., Jebb S.A. Who consumes whole grains, and how much // Proceedings Of The Nutrition Society, 2003; 62(1): 123-127.

137. Latvijas Osteoporozes un kaulu metabolo slimību asociācija Osteoporozes klīniskās vadlīnijas. Rīga Latvijas Osteoporozes un kaulu metabolo slimību asociācija, 2011. - 39. lpp.

138. Lee J., Demissie K., Lu S.E., Rhoads G.G. Cancer incidence among Korean-American immigrants in the United States and native Koreans in South Korea // Cancer Control, 2007; 14(1): 78-85.

139. Leitzmann M.F., Stampfer M.J., Michaud D.S., Augustsson K., et al. Dietary intake of n-3 and n-6 fatty acids and the risk of prostate cancer // The American Journal of Clinical Nutrition, 2004a; 80(1): 204-216.

140. Leitzmann M.F., Platz E.A., Stampfer M.J., Willett W.C., et al. Ejaculation frequency and subsequent risk of prostate cancer // JAMA, 2004b; 291(13): 1578-1586.

141. Leitzmann M.F., Ahn J., Albanes D., Hsing A.W., et al. Diabetes mellitus and prostate cancer risk in the Prostate, Lung, Colorectal, and Ovarian Cancer Screening Trial // Cancer Causes Control, 2008; 19(10): 1267-1276.

142. Leitzmann M.F., Rohrmann S. Risk factors for the onset of prostatic cancer: age, location, and behavioral correlates // Journal of Clinical Epidemiology, 2012; 4: 1-11.

143. Lejnieks A., Slaidina A., Zvaigzne A., Soboleva U., et al. Vitamin D Status and Its Seasonal Variations and Association With Parathyroid Hormone Concentration in Healthy Women in Riga.// Medicina (Kaunas), 2013; 49(7): 329-334.

144. Li H., Stampfer M.J., Hollis J.B., Mucci L.A., et al. A prospective study of plasma vitamin D metabolites, vitamin D receptor polymorphisms, and prostate cancer // PLOS Medicine, 2007; 4(3): 103.

145. Lichtenstein P., Holm N.V., Verkasalo P.K., Iliadou A., et al. Environmental and heritable factors in the causation of cancer--analyses of cohorts of twins from Sweden, Denmark, and Finland // New England Journal of Medicine, 2000; 2: 78-85.

146. Lietuvas Republikas Veselības Aizsardzības ministrija. Republikas Pārtikas centrs. Pārtikas produktu un ēdienu porciju fotoatēlu atlants. - Rīga: A/s Sabiedrības veselības aǵentūra, 2007

147. Lilleby W., Torlakovic G., Torlakovic E., et al. Prognostic significance of histologic grading in patients with prostate carcinoma who are assessed by the Gleason and World Health Organization grading systems in needle biopsies obtained prior to radiotherapy // Cancer, 2001; 92: 311-319.

148. Linko A.M., Parikka K., Wahala K., Adlercreutz H. Gas chromatographic-mass spectrometric method for the determination of alkylresorcinols in human plazma // Analytical Biochemistry, 2002; 308(2): 307-313.

149. Linko A.M., Adlercreutz H. Whole-grain rye and wheat alkylresorcinols are incorporated into human erythrocyte membranes // British Journal of Nutrition, 2005; 93(1): 11-13.

150. Linko-Parvinen A.M., Landberg R., Tikkanen M.J., Adlercreutz H., et al. Alkylresorcinols from whole-grain wheat and rye are transported in human plasma lipoproteins // Journal of Nutrition, 2007; 137(5): 1137-1142.

151. Liu Y., Hu F., Li D., et al. Does physical activity reduce the risk of prostate cancer? A systematic review and meta-analysis // European Urology, 2011; 60(5): 1029-1044.

152. Lou Y.R., Laaksi I., Syvala H., Blauer M., et al. 25-hydroxyvitamin D3 is an active hormone in human primary prostatic stromal cells // The FASEB Journal, 2004a; 18(2): 332-334.

153. Lou Y.R., Qiao S., Talenpoika R., Syvala H., et al. The role of Vitamin D3 metabolism in prostate cancer // The Journal of Steroid Biochemistry and Molecular Biology, 2004b; 92(4): 317-325. 
154. Low Y.L., Taylor J.I., Grace P.B., Dowsett M., et al. Polymorphisms in the CYP19 gene may affect the positive correlations between serum and urine phytoestrogen metabolites and plasma androgen concentrations in men // Journal of Nutrition, 2005; 135(11): 2680-2686.

155. Ma J., Giovannucci E., Mucci L., Qiu W., et al. Prediagnostic body-mass index, plasma C-peptide concentration, and prostate cancer-specific mortality in men with prostate cancer: a long-term survival analysis // The Lancet Oncology, 2008; 9(11): 1039-1047.

156. MacInnis R.J., English D.R. Body size and composition and prostate cancer risk: systematic review and meta-regression analysis // Cancer Causes Control, 2006; 17(8): 989-1003.

157. Malik V.S., Hu F.B. Dietary prevention of atherosclerosis: go with whole grains // The American Journal of Clinical Nutrition, 2007; 85(6): 1444-1445.

158. Mattila P., Pihlava J.M., Hellstrom J. Contents of phenolic acids, alkyl- and alkenylresorcinols, and avenanthramides in commercial grain products // Journal of Agricultural and Food Chemistry, 2005; 53(21): 290-295.

159. McCann S.E., Ambrosone C.B., Moysich K.B., Brasure J., et al. Intakes of selected nutrients, foods, and phytochemicals and prostate cancer risk in western New York // Nutrition and Cancer, 2005; 53(1): 33-41.

160. Meija L., Erdmane D., Ignace G., Siksna I., et al. Dietary fiber intake and food sources in aged man and women in Latvia // 5th International Dietary Fibre Conference 2012. 7-9 May 2012, Rome, Italy. Book of Abstarcts “5th International Dietary Fibre Conference 2012”, 2012; 65.

161. Meija L., Samaletdin A., Koskela A., Lejnieks A., et al. Alkylresorcinols in Latvian and Finnish breads // International Journal of Food Sciences and Nutrition, 2013a; 64(1): 117-121.

162. Meija L., Soderholm P., Samaletdin A., Ignace G., et al. Dietary intake and major sources of plant lignans in Latvian men and women // International Journal of Food Sciences and Nutrition, 2013b; 64(5): 535-543.

163. Milder I.E.J., Arts I.C.W., Venema D.P., Lasaroms J.J.P., et al. Optimization of a liquid chromatography-tandem mass spectrometry method for quantification of the plant lignans secoisolariciresinol, matairesinol, lariciresinol, and pinoresinol in foods // Journal of Agricultural and Food Chemistry, 2004; 52(15): 4643-4651.

164. Milder I.E., Feskens E.J., Arts I.C., Bueno de Mesquita H.B., et.al Intake of the plant lignans secoisolariciresinol, matairesinol, lariciresinol, and pinoresinol in Dutch men and women // Journal of Nutrition, 2005a; 135: 1202-1207.

165. Milder I.E., Arts I.C., Van de Putte B., Venema D.P., et al. Lignan contents of Dutch plant foods: a database including lariciresinol, pinoresinol, secoisolariciresinol and matairesinol // British Journal of Nutrition, 2005b; 93: 393-402.

166. Milder I.E., Kuijsten A., Feskens E.J., Kampman E., et al. Relation between plasma enterodiol and enterolactone and dietary intake of lignans in a Dutch endoscopy-based population // Journal of Nutrition, 2007; 137(5): 1266-1271.

167. Monroe K.R,. Murphy S.P., Henderson B.E., Kolonel L.N., et al. Dietary fiber intake and endogenous serum hormone levels in naturally postmenopausal Mexican American women: the Multiethnic Cohort Study // Nutrition and Cancer, 2007; 58(2): 127-135.

168. Moore C.K., Karikehalli S., Nazeer T., Fisher H.A., et al. Prognostic significance of high grade prostatic intraepithelial neoplasia and atypical small acinar proliferation in the contemporary era // Journal of Urology, 2005; 1: 70-72.

169. Moreno-Franco B., Garcia-Gonzalez A., Montero-Bravo A.M., Iglesias-Gutierrez E., et al. Dietary alkylresorcinols and lignans in the Spanish diet: development of the alignia database // Journal of Agricultural and Food Chemistry, 2011; 59: 9827-9834.

170. Moutsatsou P. spectrum of phytoestrogens in nature: our knowledge is expanding // Hormones (Athens), 2007; 6(3): 173-193.

171. Moyad M.A. Dietary fat reduction to reduce prostate cancer risk: controlled enthusiasm, learning a lesson from breast or other cancers, and the big Picture // Urology, 2002; 59(4): 51-62. 
172. Muller H., Raum E., Rothenbacher D., Stegmaier C., et al. Association of diabetes and body mass index with levels of prostate-specific antigen: implications for correction of prostate-specific antigen cutoff values? // Cancer Epidemiology, Biomarkers \& Prevention, 2009; 18: 1350.

173. Murtola T.J., Tammela T.L., Maattanen L., Huhtala H., et al. Prostate cancer and PSA among statin users in the Finnish prostate cancer screening trial // Journal of the National Cancer Institute, 2010; 127(7): 1650-1659.

174. Nacionālais diagnostikas centrs. Latvijas iedzīvotāju visaptverošais pārtikas patēriṇa pētījums 2007-2009. - Rīga: Nacionālais diagnostikas centrs, 2009.

175. National Cancer Institute. National Cancer Institute FactSheet // http://www.cancer.gov/cancertopics/factsheet/detection/staging (sk. 03.09.2013.)

176. National Nutrition Council. Finnish Nutrition recommendations // http://www.ravitsemusneuvottelukunta.fi/portal/en/nutrition_recommendations/ (sk, 15.03.2012.).

177. National Research Council \& Comitee on Diet, Nutrition and Cancer. Diet, Nutrition and Cancer Washington, D.C.: National Academy Press, 1982. - Pp. 478

178. Noel W.C., Claire A.H., Mick D.B. Molecular mechanisms of metastasis in prostate cancer // Asian Journal of Andrology, 2009; 11: 57-67.

179. Nordic Council of Ministers. (2003). The Norbagreen 2002 study. Consumption of vegetables, potatoes, fruit, bread and fish in the Nordic and Baltic countries // TemaNord, 2003; 556.

180. Nurmi T., Mursu J., Penalvo J.L., Poulsen H.E., et al. Dietary intake and urinary excretion of lignans in Finnish men // British Journal of Nutrition, 2010; 103: 677-685.

181. Onitilo A.A., Engel J.M., Glurich I., Stankowski R.V., et al. Diabetes and cancer I: risk, survival, and implications for screening // Cancer Causes Control, 2012; 23(6): 967-981.

182. Park S.Y., Murphy S.P., Wilkens L.R., Stram D.O., et al. Calcium, vitamin D, and dairy product intake and prostate cancer risk: the Multiethnic Cohort Study // American Journal of Epidemiology, 2007; 166(11): 1259-1269.

183. Park S.Y., Wikens L.R., Franke A.A., Le Marchand L., et al. Urinary phytoestrogen excretion and prostate cancer risk: a nested case-control study in the Multiethnic Cohort // British Journal of Nutrition, 2009; 101(1): 185191.

184. Peeters P.H., Slimani N., Van der Schouw Y.T., Grace P.B., et al. Variations in plasma phytoestrogen concentrations in European adults // Journal of Nutrition, 2007; 137(5): 1294-1300.

185. Pellegrini N., Valtuena S., Ardigo D., Brighenti F., et al. Intake of the plant lignans matairesinol, secoisolariciresinol, pinoresinol, and lariciresinol in relation to vascular inflammation and endothelial dysfunction in middle age-elderly men and post-menopausal women living in Northern Italy // Nutrition, Metabolism \& Cardiovascular Diseases, 2010; 20(1): 64-71.

186. Pelucchi C., Talamini R., Galeone C., Negri E., et al. Fibre intake and prostate cancer risk // Fibre intake and prostate cancer risk, 2004; 109(2): 278-280.

187. Penalvo J.L., Haajanen K.M., Botting N., Adlercreutz H. Quantification of lignans in food using isotope dilution gas chromatography/mass spectrometry // Journal of Agricultural and Food Chemistry, 2005a; 53(24): 9342-9347.

188. Penalvo J.L., Heinonen S.M., Aura A.M., Adlercreutz H. Dietary sesamin is converted to enterolactone in humans // Journal of Nutrition, 2005b; 5(135): 1056-1062.

189. Perez-Jimenez J., Hubert J., Hooper L., Cassidy A. Urinary metabolites as biomarkers of polyphenol intake in humans: a systematic review // The American Journal of Clinical Nutrition, 2010; 94(4): 801-809.

190. Peterson J., Dwyer J., Adlercreutz H., Scalbert A., et al. Dietary lignans: physiology and potential for cardiovascular disease risk reduction // Nutrition Reviews, 2010; 10: 571-603.

191. Pettersson A., Kasperzyk J.L., Kenfield S.A., Richman E.L., et al. Milk and dairy consumption among men with prostate cancer and risk of metastases and prostate cancer death // Cancer Epidemiology, Biomarkers \& Prevention, 2012; 21(3): 428-436. 
192. Platz E.A., Leitzmann M.F., Visvanathan K., Rimm E.B., et al. Statin drugs and risk of advanced prostate cancer // Journal of the National Cancer Institute, 2006; 98(24): 1819-1825.

193. Pludowski P., Karczmarewicz E., Bayer M., Carter G., et al. Practical guidelines for the supplementation of vitamin D and the treatment of deficits in Central Europe - recommended vitamin D intakes in the general population and groups at risk of vitamin D deficiency // Endokrynologia Polska, 2013; 64(4): 319-327.

194. Pudule I., Villeruša A., Grīnberga D., Velika B., M., Daiga Behmane, Dzērve V., Prättälä R.. Latvijas iedzīvotāju veselību ietekmējošo paradumu pētījums 2010. - Rīga: Veselības ekonomikas centrs, 2011.

195. Qin L.Q., Xu J.Y., Wang P.Y., Tong J., et al. Milk consumption is a risk factor for prostate cancer in Western countries: evidence from cohort studies // Asia Pacific Journal of Clinical Nutrition, 2007; 16(3): 467-476.

196. Rastogi T., Devesa S., Mangtani P., Mathew A., et al. Cancer incidence rates among South Asians in four geographic regions: India, Singapore, UK and US // International Journal of Epidemiology, 2008; 37(1): 147-160.

197. Roddam A.W., Allen N.E., Appleby P., Key T.J. Endogenous sex hormones and prostate cancer: a collaborative analysis of 18 prospective studies // Journal of the National Cancer Institute, 2008; 100(3): 170-183.

198. Rodriguez C., Freedland S.J., Deka A., Jacobs E.J., et al. Body mass index, weight change, and risk of prostate cancer in the Cancer Prevention Study II Nutrition Cohort // Cancer Epidemiology, Biomarkers \& Prevention, 2006; 16(1): 63-69.

199. Ross A.B., Kamal-Eldin A., Jung C., Shepherd M.J., et al. Gas chromatographic analysis of alkylresorcinols in rye (Secale cereale L) grains // Journal of the Science of Food and Agriculture, 2001; 81(14): 1405-1411.

200. Ross A.B., Shepherd M.J., Schupphaus M., Sinclair V., et al. Alkylresorcinols in cereals and cereal products // Agricultural and Food Chemistry, 2003a; 51(14): 4111-4118.

201. Ross A.B., Kamal-Eldin A., Lundin E.A., Zhang J.X., et al. Cereal alkylresorcinols are absorbed by humans // Journal of Nutrition, 2003b; 133(7): 2222-2224.

202. Ross A.B., Kamal-Eldin A., Aman P. Dietary alkylresorcinols: absorption, bioactivities, and possible use as biomarkers of whole-grain wheat- and rye-rich foods // Nutrition Reviews, 2004; 62(3): 81-95.

203. Ross A.B., Becker W., Chen Y., Kamal-Eldin A., et al. Intake of alkylresorcinols from wheat and rye in the United Kingdom and Sweden // British Journal of Nutrition, 2005; 94(4): 496-499.

204. Ross A.B. Present status and perspectives on the use of alkylresorcinols as biomarkers of wholegrain wheat and rye intake // Journal of Nutrition and Metabolism, 2012a; 2012: 1-12.

205. Ross A.B., Bourgeois A., Macharia H.N., Kochhar, S., et al. Plasma alkylresorcinols as a biomarker of whole-grain food consumption in a large population: results from the WHOLEheart Intervention Study // The American Journal of Clinical Nutrition, 2012b; 95(1): 204-211.

206. Saarinen N.M., Tuominen J., Pylkkanenm Santti R. Assessment of information to substantiate a health claim on the prevention of prostate cancer by lignans // Nutritients, 2010; 2(2): 99-115.

207. Saleem M., Kim H.J., Ali M.S., LeeY.S. An update on bioactive plant lignans // Natural Product Reports, 2005; 6: 696-716.

208. Schmid H.P., Fischer C., Engeler D.S., Bendhack M.L., et al. Nutritional aspects of primary prostate cancer prevention // Recent Results in Cancer Research, 2011; 188:101-107.

209. Schuurman A.G., Van der Brandt P.A., Dorant E., Brants H.A., et al. Association of energy and fat intake with prostate carcinoma risk: results from The Netherlands Cohort Study // Cancer, 1999; 86(6): 1019-1027.

210. Schwartz G.G., Hanchette C.L. UV, latitude, and spatial trends in prostate cancer mortality: all sunlight is not the same (United States) // Cancer Causes Control, 2006; 17(8): 1091-1101. 
211. Schwartz G.G. Vitamin D and intervention trials in prostate cancer: from theory to therapy // Annals of Epidemiology, 2009; 19(2): 96-102.

212. Seal C.J., Jones A.R., Whitney A.D. Whole grains uncovered // Nutrition Bulletin, 2006; 31(2): 129-137.

213. Setchell K.D., Lawson A.M., Mitchell F.L., Adlercreutz H., et al. Lignans in man and in animal species // Nature, 1980; 287(5784): 740-742.

214. Shirai T., Asamoto M., Takahashi S., Imaida K. Diet and prostate cancer // Toxicology, 2002; 181 182: 89-94.

215. Sjodin A., Hagmar :L., Klasson-Wehler E., Bjork J., et al. Influence of the consumption of fatty Baltic Sea fish on plasma levels of halogenated environmental contaminants in Latvian and Swedish men // Environmental Health Perspectives, 2000; 108(11): 1035-1041.

216. Slavin J., Why whole grains are protective: biological mechanisms // Proceedings of the Nutrition Society, 2003; 62(1): 129-134.

217. Slavin J., Whole grains and human health // Nutrition Research Reviews, 2004; 1: 99-110.

218. Slimību profilakses un kontroles centrs. Statistikas dati par 2011. gadu // www.spkc.gov.lv/file_download/903/ONKO_2011_v3.docx (sk. 05.08.2012.).

219. Soderholm P.P., Koskela A.H., Lundin J.E., Tikkanen M.J. et al. Plasma pharmacokinetics of alkylresorcinol metabolites: new candidate biomarkers for whole-grain rye and wheat intake // The American Journal of Clinical Nutrition, 2009; 90(5): 1167-1171.

220. Soderholm, P.P., Lundin J.E., Koskela A.H., Tikkanen M.J., et al. Pharmacokinetics of alkylresorcinol metabolites in human urine // British Journal of Nutrition, 2011; 106(7): 10401044.

221. Stasiuk M., Kozubek A. Biological activity of phenolic lipids // Nutrition Reviews, 2010; 67(6): 841-860.

222. Stattin P., Bylund A., Biessy C., Kaaks R., et al. Prospective study of plasma enterolactone and prostate cancer risk (Sweden) // Cancer Causes Control, 2004; 15(10): 1095-1102.

223. Strandas C., Kamal-Eldin A., Andersson R., Aman P. Phenolic glucosides in bread containing flaxseed // Food Chemistry, 2008; 4(110): 997-999.

224. Strom S.S., Yamamura Y., Duphorne C.M., Spitz M.R., et al. Phytoestrogen intake and prostate cancer: a case-control study using a new database // Nutrition and Cancer, 1999; 33(1): 20-25.

225. Stumpf K., Uehara M., Nurmi T., Adlercreutz H. Changes in the time-resolved fluoroimmunoassay of plasma enterolactone // Analytical Biochemistry, 2000; 284: 153-157.

226. Su L.J., Arab L., Steck S.E., Fontham E.T., et al. Obesity and prostate cancer aggressiveness among African and Caucasian Americans in a population-based study // Cancer Epidemiology, Biomarkers \& Prevention, 2011; 20(5): 844-853.

227. Suzuki R., Rylander-Rudqvist T., Saji S., Bergkvist L., et al. Dietary lignans and postmenopausal breast cancer risk by oestrogen receptor status: a prospective cohort study of Swedish women // British Journal of Cancer, 2008; 98(3): 636-640.

228. Suzuki R., Allen N.E., Key T.J., Appleby P.N., et al. A prospective analysis of the association between dietary fiber intake and prostate cancer risk in EPIC // International Journal of Cancer, 2009; 124(1): 245-249.

229. Swami S., Krishnan A.V., Peehl D.M., Feldman D. Genistein potentiates the growth inhibitory effects of 1,25-dihydroxyvitamin D3 in DU145 human prostate cancer cells: role of the direct inhibition of CYP24 enzyme activity // Molecular and Cellular Endocrinology, 2005; 241(1-2): 4961.

230. Swami S., Krishnan A.V., Moreno J., Bhattacharyya R.B., et al. Calcitriol and genistein actions to inhibit the prostaglandin pathway: potential combination therapy to treat prostate cancer // Journal of Nutrition, 2007; 137(1): 205-210. 
231. Syed D.N., Khan N., Afag F., Mukhtar H. Chemoprevention of prostate cancer through dietary agents: progress and promies // Cancer Epidemiology, Biomarkers \& Prevention, 2007; 16(11): 2193-2203.

232. Szymanski K.M., Wheeler D.C., Mucci L.A. Fish consumption and prostate cancer risk: a review and meta-analysis // The American Journal of Clinical Nutrition, 2010; 92(5): 1223-1233.

233. Tannenbaum, A. The Genesis and growth of tumors: II Effects of caloric restriction per se // Cancer Research , 1942a; 2: 460-467.

234. Tannenbaum, A. The Genesis and growth of tumors: III Effects Effect of a high fat diet // Cancer Research, 1942b; 2: 468 -474.

235. Teede H.J., Dalais F.S., McGrath B.P. Dietary soy containing phytoestrogens does not have detectable estrogenic effects on hepatic protein synthesis in postmenopausal women // The American Journal of Clinical Nutrition, 2004; 79: 396-401.

236. Tewari R., Rajender S., Natu S.M., Dalela D., et al. Diet, Obesity, and Prostate Health: Are We Missing the Link? // Journal of Andrology, 2012; 33(5): 763-776.

237. Thompson L.U., Boucher B.A., Liu Z,. Cotterchio M., et al. . Phytoestrogen content of foods consumed in Canada, including isoflavones, lignans, and coumestan // Nutrition and Cancer, 2006; 2: 184-201.

238. Tirzītis G., Šķeters A., Skābekḷa atvasinājumu un brīvo radikāḷu bioḳ̄imiskie aspekti bioloǵijā. Rīga: LU Akadēmiskais apgāds, 2007. - 26.-27.;97. lpp.

239. Torfadottir J.E., Valdimarsdottir U.A., Mucci L., Stampfer M., et al. Rye bread consumption in early life and reduced risk of advanced prostate cancer // Cancer Causes Control, 2012; 23(6): 941-950.

240. Touillaud M.S., Thiebaut A.C., Fournier A., Niravong M., et al. Dietary lignan intake and postmenopausal breast cancer risk by estrogen and progesterone receptor status // Journal of the National Cancer Institute, 2007; 99(6): 475-486.

241. Travis R.C., Spencer E.A., Allen N.E., Appleby P.N., et al. Plasma phyto-oestrogens and prostate cancer in the European Prospective Investigation into Cancer and Nutrition // Plasma phytooestrogens and prostate cancer in the European Prospective Investigation into Cancer and Nutrition, 2009a; 100(11): 1817-1823.

242. Travis R.C., Crowe F.L., Allen N.E., Appleby P.N., et al. Serum vitamin D and risk of prostate cancer in a case-control analysis nested within the European Prospective Investigation into Cancer and Nutrition (EPIC) // American Journal of Epidemiology. 2009b; 169(10): 1223-1232.

243. Tretli S., Hernes E., Berg J.P., Hestvik U.E., et al. Association between serum 25(OH)D and death from prostate cancer // British Journal of Cancer, 2009; 100(3): 450-454.

244. Trump D. L., Chadna M. K., Sunga A. Y., et al. Vitamin D deficiency and insufficiency among patients with prostate cancer // BJU International, 2009; 104: 909-914.

245. Tsuji M., Tamai Y., Wada K., Nakamura K. et al. Associations of intakes of fat, dietary fiber, soy isoflavones, and alcohol with levels of sex hormones and prolactin in premenopausal Japanese women // Cancer Causes Control, 2012; 23(5):683-689.

246. Tuohima P., Tenkanen L., Ahonen M., Lumme S., et al. Both high and low levels of blood vitamin $\mathrm{D}$ are associated with a higher prostate cancer risk: a longitudinal, nested case-control study in the Nordic countries // International Journal of Cancer, 2004; 108(1): 104-108.

247. UK Food Standards Agency. (2007). The eatwell plate // http://www.nhs.uk/Livewell/Goodfood/Pages/eatwell-plate.aspx (sk. 5.01.2012.).

248. United States Department of Agriculture. (2010). Dietary Guidelines for Americans // www.cnpp.usda.gov/DGAs2010-PolicyDocument.htm (sk. 6.02.2012.).

249. University of Cambridge. EPIC-Norfolk: nutritional methods. Food frequency questionnaire // http://www.srl.cam.ac.uk/epic/images/ffq.pdf (sk.25.10.2008a.).

250. University of Cambridge. EPIC-Norfolk: nutritional methods. Seven-day diary // http://www.srl.cam.ac.uk/epic/nutmethod/7dd.shtml (sk.25.10.2008b.). 
251. U.S. Food and Drug Administration. (2006). FDA Provides Guidance on 'Whole Grain' for Manufacturers //

http://www.fda.gov/NewsEvents/Newsroom/PressAnnouncements/2006/ucm108598.htm (sk. 5.02.2012.).

252. Valsta L.M., Kilkkinen A., Mazur W., Nurmi T., et al. Phyto-oestrogen database of foods and average intake in Finland // British Journal of Nutrition, 2003; 89(1): 31-38.

253. Van der Kamp, J.W. Paving the way of innovation in enhancing the intake of whole grain // Trends in Food Science \& Technology, 2012; 25(2): 101-107.

254. Van der Rhee H., Coebergh J.W., De Vries E. Sunlight, vitamin D and the prevention of cancer: a systematic review of epidemiological studies // European Journal of Cancer Prevention, 2009; 18(6): 458-475.

255. Venkitaraman R., Thomas K., Grace P., Dearnaley D., et al. Baseline urinary phytoestrogen levels and the natural history of untreated, localised prostate cancer in a British population // The International Journal of Biological Markers, 2008; 23(3): 192-197.

256. Veselības Ministrija. (2008). Veselīga uztura ieteikumi pieaugušajiem 2008.gada rīkojums Nr.201., 2008.

257. Vieth R., Choo R., Deboer L., Danjoux C., et al. Rise in prostate-specific antigen in men with untreated low-grade prostate cancer is slower during spring-summer // American Journal of Therapeutics, 2006; 13(5): 394-399.

258. Virk-Baker M.K., Nagy T.R., Barnes S. Role of phytoestrogens in cancer therapy // Planta Medica, 2010; 11:1132-1142.

259. Walker M., Aronson K.J., King W., Wilson J.W., et al. Dietary patterns and risk of prostate cancer in Ontario, Canada // International Journal of Cancer, 2005; 116(4): 592-598.

260. Wallstrom P., Bjartell A., Gullberg B., Olsson H., et al. A prospective study on dietary fat and incidence of prostate cancer (Malmö, Sweden) // Cancer Causes Control, 2007; 18(10): 1107-1121.

261. Waltz P., Chodick G. Assessment of ecological regression in the study of colon, breast, ovary, nonHodgkin's lymphoma, or prostate cancer and residential UV // European Journal of Cancer Prevention, 2008;17(3): 279-286.

262. Wang C., Catlin D.H., Starcevic B.,Heber D., et al. -fat high-fiber diet decreased serum and urine androgens in men // The Journal of Clinical Endocrinology \& Metabolism. 2005; 90(6): 35503559.

263. Ward B. The Story of Medicine. - New York: Rosen Publishing Group Inc., 2012. - Pp.12.-13.

264. Ward H., Chapelais G., Kuhnle G.G., Luben R., et al. Lack of prospective associations between plasma and urinary phytoestrogens and risk of prostate or colorectal cancer in the European Prospective into Cancer-Norfolk study // Cancer Epidemiology, Biomarkers \& Prevention, 2008; 17(10): 2891-2894.

265. Watters K.M., Henderson B.E., Stram D.O., Wan P., et al. Association of diabetes with prostate cancer risk in the multiethnic cohort // American Journal of Epidemiology, 2009; 169(8): 937-945.

266. Watters J.L., Park Y., Hollenbeck A., Schatzkin A., et al. Alcoholic beverages and prostate cancer in a prospective US cohort study // American Journal of Epidemiology, 2010; 172(7): 773-780.

267. Wei M.Y., Giovannucci E.L. Lycopene, Tomato Products, and Prostate Cancer Incidence: A Review and Reassessment in the PSA Screening Era // Journal of Oncology, 2012; 271063: 1-7.

268. Whitlatch L.W., Young M.V., Schwartz G.G., Flanagan J.N., et al. 25-Hydroxyvitamin D-1alphahydroxylase activity is diminished in human prostate cancer cells and is enhanced by gene transfer // The Journal of Steroid Biochemistry and Molecular Biology, 2002; 82(2): 130-140.

269. Wild C.P., Andersson C., O’Brien N.M., Wilson L., et al. A critical evaluation of the application of biomarkers in epidemiological studies on diet and health // British Journal of Nutrition, 2001; 86(1): 37-53.

270. Willet W. Nutritional Epidemiology. - Oxford: Oxford University Press, 2013. - 260.;283.; 287.; 303. 1pp. 
271. Wilson K.M., Kasperzyk J.L., Rider J.R., Kenfield S., et al. Coffee consumption and prostate cancer risk and progression in the Health Professionals Follow-up Study // Journal of the National Cancer Institute, 2011; 103(11): 876-884.

272. Woo T.C., Choo R., Jamieson M., Chander S., et al. Pilot study: potential role of vitamin D (Cholecalciferol) in patients with PSA relapse after definitive therapy // Nutrition and Cancer, 2005; 51(1): 32-36.

273. World Cancer Research Fund / American Institute for Cancer Research. Food, Nutrition, Physical Activity, and the Prevention of Cancer: a Global Perspective // http://eprints.ucl.ac.uk/4841/1/4841.pdf (sk. 07.07.2013.).

274. Wu W.H., Kang Y.P., Jou H.J., Wang T.A. Sesame ingestion affects sex hormones, antioxidant status, and blood lipids in postmenopausal women // Journal of Nutrition, 2006; 136(5): 12701275.

275. Wynder E.L., Peters J.A., Vivona S. Nutrition in the causation of cancer // Cancer Research, 1975; 35: 3231-3235.

276. Yin L., Raum E., Haug U., Arndt V., et al. Meta-analysis of longitudinal studies: Serum vitamin D and prostate cancer risk // Cancer Epidemiology, 2009; 33(6): 435-445.

277. Zamora-Ros R., Knaze V., Lujan-Barosso L., Kuhnle G.G., et al. Dietary intakes and food sources of phytoestrogens in the European Prospective Investigation into Cancer and Nutrition (EPIC) 24hour dietary recall cohort // European Journal of Clinical Nutrition, 2012; 66: 932-941.

278. Zariņš Z., Neimane L. Uztura mācība. - Rīga: LU Akadēmiskais apgāds, 2009. - 183.-184.; 329. 1pp.

279. Zheng J., Yang B., Huang T., Yu Y., Yang J., et al. Cancer chemoprevention with garlic and its constituents // Cancer Letters, 2007; 247(2): 167-181.

280. Zheng J., Yang B., Huang T., Yu Y., et al. Green tea and black tea consumption and prostate cancer risk: an exploratory meta-analysis of observational studies // Nutrition and Cancer, 2011; 63(5): 663-672.

281. Zhu Y., Conklin D.R., Chen H., Wang L., et al. 5-alk(en)ylresorcinols as the major active components in wheat bran inhibit human colon cancer cell growth // Bioorganic \& Medicinal Chemistry, 2011; 19(13): 3973-3982. 


\section{PUBLIKĀCIJAS PAR PROMOCIJAS DARBA TĒMU}

\section{Raksti starptautiski recenzējamos izdevumos}

1. Meija L., Samaletdin A., Koskela A., Lejnieks A., Lietuvietis V, Adlercreutz H. Alkylresorcinols in Latvian and Finnish breads // International Journal of Food Sciences and Nutrition, 2013a; 64(1): 117-121.

2. Meija L., Soderholm P., Samaletdin A., Ignace G., Siksna I, Joffe R, Lejnieks A, Lietuvietis V, Krams I, Adlercreutz H. Dietary intake and major sources of plant lignans in Latvian men and women // International Journal of Food Sciences and Nutrition, 2013b; 64(5): 535-543.

3. Meija L., Ignace G., Cauce V., Siksna I., Joffe, N. Bobere, V. Lietuvietis, A. Lejnieks, P. Söderholm, H. Adlercreutz. Consumption of the Whole-Grain Rye Bread and Progression of Prostate Cancer // Proceedings of the Latvian Academy of Sciences. Section B. Natural, Exact, and Applied Sciences, 2013; 0(0): 20-23.

4. Bobere N., Podjava A., Meija L., Jakobsone I. Determination of alkylresorcinols by HPLC-UV in cereals breed in Latvia // Proceedings of the Latvian Academy of Sciences, Section B Natural, Exact, and Applied Sciences, 2013; in press.

\section{Raksti Latvijas zinātniskos izdevumos}

1. Meija L., Šitova A., Rūsa Z., Erdmane D., Joffe R., Teibe U., Lietuvietis V., Lejnieks A. Vitamīna D ietekme uz prostatas specifiskā antigēna līmeni serumā vīriešiem vecumā ar palielinātu priekšdziedzera vēža attīstības risku // RSU Zinātniskie raksti 2010. gada medicīnas nozares pētnieciskā darba publikācijas, 2010; 2: 209-215.

2. Meija L., Ignace G., Joffe R., Siksna I., Lietuvietis L., Lejnieks A. Lignāni iespējamais vēža preventīvais faktors - Latvijas iedzīvotāju uzturā // RSU Zinātniskie raksti 2011. gada medicīnas nozares pētnieciskā darba publikācijas, 2011; $1: 263-269$.

3. Meija L., Cauce V., Ignace G., Siksna I., Lietuvietis L.,Lejnieks A. D vitamīns uzturā un serumā priekšdziedzera vēža pacientiem un kontroles grupas vīriešiem // RSU Zinātnisko rakstu 2013. gada medicīnas nozares pētnieciskā darba publikāciju 1.sējumums, pieņemts publicēšanai. 


\section{Starptautisko konferenču un kongresu tēzes}

1. Meija L., Joffe R., Šitova A., Teibe U., Belicka I., Lietuvietis V., Lejnieks A. Cereal fiber intake in men at the risk age of prostate cancer. Konference "Enhancing health benefits of cereal foods - results, perspectives and challenges", May 2010, Lund, Sweden. Abstract book, 2010;146

2. Meija L., Šitova A., Doncovs A., Teibe U., Lietuvietis V., Lejnieks A. Vitamin D deficiency in aged men with risk of prostate cancer. Baltijas Onkologijas kongress 2010.gada maijā // Acta Chirurgica Latviensis, Supplement 2010 (10/1) Abstracts 5th Baltic Congress of Oncology; 63

3. Meija L., Šitova A., Rūsa Z., Erdmane D., Joffe R., Teibe U., Lietuvietis V., Lejnieks A. Vitamin D intake and deficiency in men at risk of prostate cancer. „EAU (European Association of Urology) 4 North Eastern European Meeting (NEEM)" // Eur Urol Suppl 2010;9(6):536.

4. Meija L, Kalnins I, Lietuvietis V, Lejnieks A. Body mass index, vitamin D and PSA level in aged man // Scope summer school 2011. Abstract book, 2011; 47.

5. L. Meija, G. Ignace, V. Cauce, I. Siksna, R. Joffe, V. Lietuvietis, A. Lejnieks, P. Söderholm, H. Adlercreutz. Major dietary factors and prostate cancer risk: a case control study // International conference "Nutrition and health" Riga, Latvia, September 4-6, 2012. Book of Abstracts; 57.

6. L. Meija, G. Ignace, Z. Rūsa, R. Joffe, V. Lietuvietis, A. Lejnieks. Vitamin D status in prostate cancer patients and aged man // Abstracts of the 34th ESPEN Congress Barcelona, Spain, 8-11 September 2012. Clin Nutr. 2012; 7 (1); 243. Piešķirts novērtējums: „Outstanding abstract”

\section{Latvijas zinātnisko konferenču tēzes}

1. Meija L., Šitova A., Teibe U., Lietuvietis V., Lejnieks A. Tauki uzturā iespējamais priekšdziedzera vēža attīstību veicinošais faktors // RSU 2010. gada Zinātniskā konference. Tēzes, 2010; 275. 


\section{Mutiski ziṇojumi starptautiskos kongresos un konferencēs}

1. Meija L., Ignace G., Siksna I., Joffe R., Lietuvietis V., Lejnieks A.. Cereal fiber intake in aged men and women // V Latvian Gastroenterology Congress with International participation ABSTRACT BOOK. Rīga Stradinšs University 10th Scientific Conferences Abstract Book Supplement I; 23.

2. Laila Meija. Prostate cancer and dietary factors - situation in Latvia. ScanBalt Academy meeting. Szczecin, Poland.September 20-21, 2011.

3. Meija L., Erdmane D., Ignace G., Siksna I., Joffe R., Lietuvietis V., Lejnieks A. Dietary fiber intake and food sources in aged man and women in Latvia // 5th International Dietary Fibre Conference 2012. 7-9 May 2012, Rome, Italy. Book of Abstracts "5th International Dietary Fibre Conference 2012", 2012; 65.

\section{Mutiski ziṇojumi Latvijas zinātniskajās konferencēs}

1. Meija L., Šitova A., Erdmane D., Joffe R., Kalniņš I., Lietuvietis V., Lejnieks A. Vitamīns D - iespējamais priekšdziedzera vēža attīstību kavējošais faktors // RSU 2011.gada Zinātniskā konference. Tēzes, 2011; 321.

2. Meija L., Ignace G., Joffe R., Siksna I., Lietuvietis V., Lejnieks A.. Lignāni uzturā iespējamais priekšdziedzera vēža attīstību kavējošais faktors // RSU 2012. gada Zinātniskā konference. Tēzes, 2012; 292.

3. Meija L., Cauce V., Ignace G., Joffe R., Siksna I., Lietuvietis V., Lejnieks A. Lignānu metabolisms priekšdziedzera vēža pacientiem un kontroles grupā // RSU 2013. gada Zinātniskā konference. Tēzes, 2013; 243. 


\section{PIELIKUMI}

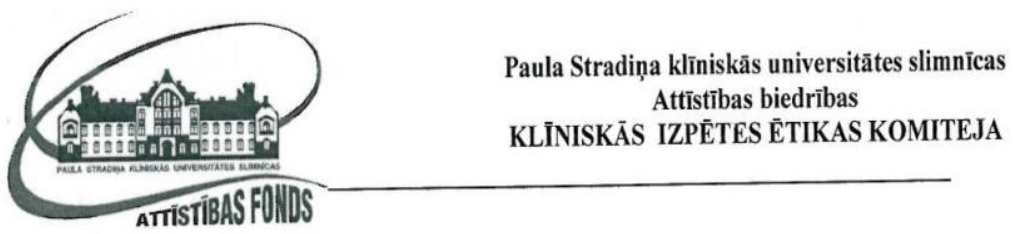

\section{Darbojas saskaṇā ar SHK LKP noteikumiem ATZINUMS Nr.251108-7L}

1. Protokola nosaukums: „Graudaugu balastvielu uzṇemšanas un priekšdziedzera vēža riska saistîbas pētijumus ar uzņemtā uztura un biomarķieru novērtējumu"

2. Protokola Nr.: nav

3. Pētnieka vārds, uzvārds RSU doktorante, Dr. Laila Meija

4. Apstiprinātie dokumenti:

Pētijuma apraksts

Informētā piekrišana par dalību pētijumā latviešu un krievu valodā

Dzīves stila, fiziskās aktivitătes un uztura aptaujas anketa

Pētnieka Curriculum Vitae

5. Ẽtikas komitejas atzinums: pozitīvs

6. Ẽtikas komitejas locekḷi, kuri piedalijjās balsošanā:

\begin{tabular}{|c|c|}
\hline Pēteris Stradiņš - kardioḳirurgs & Santa Purvina - farmakologs \\
\hline Ilze Aizsilniece - gimenes ārste & Daina Biseniece - k̦īmiķe \\
\hline Dainis Krieviņš - asinsvadu ķirurgs & Biruta Kupča - psihiatrs \\
\hline Juris Pokrotnieks - internists & Pēteris Ersts - jurists \\
\hline
\end{tabular}

Êtikas komitejas sêdes datums: 2008.gada 25.novembris.

Ẽtikas komitejas priekšsēdētājs:

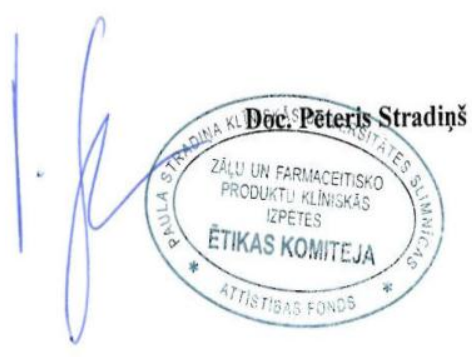

Paula Stradina klīniskās universitātes slimnīcas Attīstỉbas biedrība

Pilsoṇu 13, Rīga, LV- 1002, Tel. +371 7611353; Fax. +371 7069946, E - pasts: etikaskomiteja@stradini.lv 
KONFIDENCIĀLI

Informētā piekrišana par dalību pētījumā

Pētījuma nosaukums:

Graudaugu balastvielu uzṇemšanas un priekšdziedzera vēža riska saistības pētījums

ar uzņemtā uztura un biomarķieru novērtējumu.

\begin{tabular}{|l|}
\hline Pētījuma atbildīgā persona: \\
\hline Pacienta vārds, uzvārds: \\
\hline Personas kods: \\
\hline Pacienta pārstāvis gadījumā, ja pacients pats nav spējīgs parakstīit \\
piekrišanu:
\end{tabular}

- Ārsts mani ir informējis par pētījuma mērķi, nepieciešamajiem papildu izmeklējumiem. Esmu saņēmis/-usi citu mani interesējošo papildu informāciju.

- Esmu sañēmis/-usi visu iespējamo papildu informāciju un atbildes uz uzdotajiem papildu jautājumiem, kas saistīti ar pētījuma norisi.

- Man ir bijis pietiekami laika, lai izlemtu par savu dalību pētījumā.

- Es piekrītu tam, ka pētîjuma laikā iegūtos datus var izmantot tālākajā datu analīzē, saglabājot stingru personas konfidencialitāti.

- Es piekrītu, ka pētījumā iegūtie dati ir pieejami neatkarīgiem ekspertiem, lai veiktu neatkarīgas datu pārbaudes, ievērojot stingru konfidencialitāti.

- Es šajā pētījumā piedalos brīvprātīgi. Savu dalību es varu pārtraukt jebkurā laikā, papildus nepaskaidrojot iemeslus. Mans lēmums nekādi nevar ietekmēt tālāko ārstēšanās norisi.

\begin{tabular}{|l|l|}
\hline Datums: & Pacienta paraksts: \\
\hline Datums: & Pētnieka paraksts: \\
\hline Datums: & Pacienta pārstāvja paraksts: \\
\hline
\end{tabular}




\section{КОНФИДЕНЦИАЛЬНО}

Письменное согласие информированного пациента на участие в исследовании

Название исследования:

Исследование связи между рисом заболевания раком предстательной железы и приёмом пищи с с содержанием клетчатки в зерновых продуктах.

Исследование производится на основании анкет и биомаркеров.

\begin{tabular}{|c|}
\hline Фамилия и имя исследователя: \\
\hline Фамилия и имя пациента: \\
\hline Персональний код пациента: \\
\hline Полномочный представитель (опекун) пациента (если пациент слишком \\
стар или находится под опекой, или является юридически недееспособным): \\
\hline
\end{tabular}

- Врач устно проинформировал меня о целях наблюдения и процедурах. Также я получил/а и всю другую меня интересующую информацию .

- Я получил/а всю необходимую информацию, в связи с моим участием в клиническом наблюдении,

- Мне было достаточно времени для принятия решения о моём участии в клиническом наблюдении.

- Я согласен/a, что мои данные можно использовать для дальнейшего анализа, сохраняя строгую конфиденциальность.

- Я согласен/а, что полученные в ходе исследования мои медицинские данные доступны независимым экпертам для независимой экспертной проверки соблюдая строгую конфиденциальность.

- Я участвую в этом исследовании добровольно. Я могу прекратить своё участие в исследованиив любое время и без дополнительных объяснений. Моё решение не может повлиять на моё дальнеишее лечение.

\begin{tabular}{|l|l|}
\hline Дата: & Подпись пациента: \\
\hline Дата: & Подпись клинического исследователя: \\
\hline Дата: & Подпись полномоченогопредставителя (опекуна): \\
\hline
\end{tabular}


3. pielikums

\section{TNM klasifikācija}

TNM klasifikācija ir visplašāk lietotā vēža stadiju raksturojošā sistēma [National Cancer Institute, 2013]. TNM sistēmas nosaukums radies no pirmajiem burtiem: Tumor - primārs audzējs, Node - metastāzes reǵionālajos limfmezglos, Metastases - attālas metastāzes.

Pirmais faktors T audzēju klasifikācijā apraksta primāra audzēja apjomu.

$\mathrm{T}$ - primārais audzējs:

TX - primāru audzēju nevar novērtēt.

T0 - nav primāra audzēja.

Tis - karcinoma in situ (vēzis gḷotādas robežās).

T1-T4 - primārā audzēja izmēra un/vai lokālās izplatības palielināšanās.

Limfmezglu iesaistī̌sanās (N) klasifikācija:

$\mathrm{N}$ - reǵionālie limfmezgli:

$\mathrm{NX}$ - regiionālos limfmezglus nevar novērtēt.

N0 - nav metastāžu reǵionālajos limfmezglos.

N1-N3 - metastāzes reǵionālajos limfmezglos.

Identificējamu metastāžu esamība vai neesamība:

M - attālās metastāzes

Mx - attālas metastāzes nevar novērtēt.

M0 - nav attālu metastāžu.

M1 - pierādītas attālas metastāzes. 


\section{DZĪVESVEIDA ANKETA}

1. Personas identifikācijas numurs

2. Datums

3. Dzimšanas datums

4. Augums $\mathrm{cm}$

5. Kermeña masa $\mathrm{kg}$

6. Dzīvesvieta:

6.1. Rīga, cita pilsēta

6.2. Ciems, mazpilsēta

6.3. Lauki

7. Ģimenes stāvoklis:

7.1 . Neprecējies

7.2 . Precējies gadus

7.3 . Šķīies gadus

7.4 . Atraitnis gadus

7.5 . Dzīvo kopā ar partneri gadus Komentāri

8. Seksuālā aktivitāte, pēc pacienta vārdiem:

8.1. Līdz 30 g. vecumam:

8.1.1. Dzimumsakaru skaits nedēḷā

8.1.2. Dzimumsakaru skaits mēnesi

8.1.3. Nav dzimumsakaru

8.2. Līdz 50 g. vecumam:

8.2.1. Dzimumsakaru skaits nedēḷā

8.2.2. Dzimumsakaru skaits mēnesi

8.2.3. Nav dzimumsakaru

8.3. Pēc 50 g. vecuma:

8.3.1. Dzimumsakaru skaits nedēḷā

8.3.2. Dzimumsakaru skaits mēnesi

8.3.3. Nav dzimumsakaru

8.4. Dzimumdzīves aktivitāte pašreizējā periodā:

8.4.1. Dzimumsakaru skaits nedēḷā

8.4.2. Dzimumsakaru skaits mēnesi

8.4.3. Nav dzimumsakaru

9. Izglītība:

9.1. Pamatskola (9 klases)

9.2. Vidējā (10-12 klases)

9.3. Koledža ( $\geq 12$ gadiem)

9.4. Augstākā ( $\geq 15$ gadiem)

10. Pašreizējā nodarbošanās:

10.1. Pilnas slodzes darbs

10.2. Pusslodzes darbs

10.3. Strādā mājās

10.4. Pensijā/bez darba

11. Bērnu skaits:

11.1. Nav

11.2. Ir _ meitas

11.3. Ir _ dēli 
12. Onkologíiskā saslimstība gimenē:

12.1. Nav

12.2. Ir

12.2.1. Vēzis tēvam, konkretizēt lokalizāciju

12.2.2. Vēzis mātei, konkretizēt lokalizāciju

12.2.3 Vēzis brālim vai māsai, konkretizēt lokalizāciju

12.2.4. Vēzis bērniem, konkretizēt lokalizāciju

12.3. Nezina

13. Vai esat smēķējis pēdējo 10 gadu laikā?

13.1. Nē

13.2. Jā___ cigaretes dienā

13.3. Atmetis smēķēěsanu gadus (mēnešus)

14. Vai esat slimojis ar kādu no minētajām slimībām?

14.1. Nē

14.2. Jā. Norādiet gadu, kad pirmo reizi uzstādīta diagnoze.

14.2.1. Paaugstināts asinsspiediens ___ gadus

14.2.2. Paaugstināts holesterīns ___ gadus

14.2.3. Koronārā sirds slimība ___ gadus

14.2.4. Cerebrovaskulārā slimība ___ gadus

14.2.5. Bronhiālā astma ___ gadus

14.2.6. 2. tipa cukura diabēts___ gadus

15. Vai regulāri (vismaz 1 tabl./ned.) lietojat kādu medikamentu?

15.1. $\mathrm{Ne}$

15.2. Jā. Konkretizēt medikamenta nosaukumu un devu (iesk. paracetamolu, kortizona tabl., inhalatorus)

15.2.1. tabl. dienā/nedēḷā

15.2.2. gadus

16. Kad pēdējo reizi pirms aptaujas lietotas antibiotikas?

16.1. Norādiet, kad

16.2. Cik ilgi

16.3. Norādiet, kuras tieši antibiotikas

17. Vai regulāri (vismaz $1 \mathrm{tabl} / \mathrm{ned}$ ) lietojat vitamīnus, minerālvielas vai citus uztura bagātinātājus?

$17.1 \mathrm{Nē}$

17.2. Jā.

17.2.1. Regulāri gadus

17.2.2. Gandrīz katru dienu

17.2.3. (cik) mēnešus gadā

17.2.4. Dažreiz

18. Ja lietojat uztura bagātinātājus, norādiet, kurus tieši:

18.1. Vitamīnus, konkretizēt

18.2. Minerālvielas, konkretizēt

18.3. Citus, konkretizēt

18.4. Deva: tabl., kaps., pulveri dienā/nedēḷā 


\begin{tabular}{|c|c|c|c|c|}
\hline & $\begin{array}{c}\text { A } \\
15 \text { gadu } \\
\text { vecumā }\end{array}$ & $\begin{array}{c}\text { B } \\
30 \text { gadu } \\
\text { vecumā }\end{array}$ & $\begin{array}{c}\text { C } \\
50 \text { gadu } \\
\text { vecumā }\end{array}$ & $\begin{array}{c}\text { D } \\
\text { Šgogad } \\
\end{array}$ \\
\hline \multicolumn{5}{|l|}{ 19.1. Mājas un piemājas darbi } \\
\hline \multicolumn{5}{|l|}{ 19.1.1. Mazāk par 1 st. dienā } \\
\hline \multicolumn{5}{|l|}{ 19.1.2. 1-2 stundas dienā } \\
\hline \multicolumn{5}{|l|}{ 19.1.3. 3-4 stundas dienā } \\
\hline \multicolumn{5}{|l|}{ 19.1.4. 5-6 stundas diena } \\
\hline \multicolumn{5}{|l|}{ 19.1.5. $7-8$ stundas dienā } \\
\hline \multicolumn{5}{|l|}{ 19.1.6. Vairāk par 8 stundām dienā } \\
\hline \multicolumn{5}{|l|}{ 19.2. Staigāšana/ riteņbraukšana } \\
\hline \multicolumn{5}{|l|}{ 19.2.1. Loti reti } \\
\hline \multicolumn{5}{|l|}{ 19.2.2. Mazāk par 20 min dienā } \\
\hline \multicolumn{5}{|l|}{ 19.2.3. $\quad 20-40$ min dienā } \\
\hline \multicolumn{5}{|l|}{ 19.2.4. $40-60$ min dienā } \\
\hline \multicolumn{5}{|l|}{ 19.2.5. $1-1,5$ st. dienā } \\
\hline \multicolumn{5}{|l|}{ 19.2.6. Vairāk par 1,5 st. dienā } \\
\hline \multicolumn{5}{|l|}{ 19.3. Darbs } \\
\hline \multicolumn{5}{|l|}{ 19.3.1. Pārsvarā sēdošs } \\
\hline \multicolumn{5}{|l|}{ 19.3.2. Sēdošs pusi no darba laika } \\
\hline \multicolumn{5}{|l|}{ 19.3.3. Pārsvarā stāvošs } \\
\hline \multicolumn{5}{|l|}{$\begin{array}{l}\text { 19.3.4. Pārsvarā staigājošs, nesot } \\
\text { nelielus smagumus }\end{array}$} \\
\hline \multicolumn{5}{|l|}{$\begin{array}{l}\text { 19.3.5. Pārsvarā staigājošs, nesot } \\
\text { smagumus }\end{array}$} \\
\hline \multicolumn{5}{|l|}{ 19.3.6. Smags fizisks darbs } \\
\hline \multicolumn{5}{|l|}{ 19.4. Brīvais laiks } \\
\hline \multicolumn{5}{|l|}{ 19.4.1. Lasīšana/ TV skatīšanās } \\
\hline \multicolumn{5}{|l|}{ 19.4.1.1. Mazāk par 1 st. dienā } \\
\hline \multicolumn{5}{|l|}{ 19.4.1.2. 1-2 stundas dienā } \\
\hline \multicolumn{5}{|l|}{ 19.4.1.3. 3-4 stundas dienā } \\
\hline \multicolumn{5}{|l|}{ 19.4.1.4. 5-6 stundas dienā } \\
\hline \multicolumn{5}{|l|}{ 19.4.1.5. Vairāk par 6 st. dienā } \\
\hline \multicolumn{5}{|l|}{$\begin{array}{l}\text { 19.4.2. Vingrinājumi, fiziskā } \\
\text { aktivitāte, kas rada svīšanu vai } \\
\text { sirdsdarbības paātrināšanos }\end{array}$} \\
\hline 19.4.2.1. Mazāk par 1 st. nedēḷā & & & & \\
\hline 19.4.2.2. 1 st. nedēḷā & & & & \\
\hline 19.4.2.3. 2-3 stundas dienā & & & & \\
\hline 19.4.2.4. 4-5 stundas dienā & & & & \\
\hline 19.4.2.5. Vairāk par 5 st. nedēlāa & & & & \\
\hline
\end{tabular}


20. Diētas veids:

20.1. Omnivors

20.2. Laktoveǵetārietis (neēd gal̦u, zivis, olas)

20.3. Pārsvarā laktoveǵetārietis, dažreiz ēd zivi, olas

20.4 Vegāns

20.5. Cits veids, konkretizēt

$$
\text { Komentāri }
$$

21. Tauku veids uz sviestmaizēm:

21.1. Sviests $(80 \%$ tauku)

21.2. Sviests $50 \%+$ margarīns $50 \%$ (produkta nosaukums)

21.3. Margarīns $80 \%$ tauku (produkta nosaukums)

24.4. Vieglais margarīns $40 \%$ tauku (produkta nosaukums)

25.5. Nelietoju taukus uz sviestmaizēm

22. Tauku daudzums (sviests/margarīns) uz sviestmaizēm. Atzīmējiet, ņemot vērā ēdiena bukleta datus:

22.1. Bieza kārta

22.3. Plāna kārta

22.3. L Loti plāna kārta

22.4. Vispār nelieto taukus

23. Tauku veids, ko izmantojat ēdiena gatavošanai mājās (cepšanai). Atzīmējiet daudzumu, ņemot vērā ēdiena bukleta datus:

23.1. Sviests $(80 \%$ tauku)

23.2. Sviests $50 \%+$ margarīns $50 \%$ (produkta nosaukums)

23.3. Margarīns $80 \%$ tauku (produkta nosaukums)

23.4. Vieglais margarīns $40 \%$ tauku (produkta nosaukums)

23.5. Olivella

23.6. Rapšu elı̧a

23.7. Citas ellas (kukurūzas, saulespuku)

23.8. Nezinu. Produkta nosaukums

24. Tauku veids, ko izmantojat salātos. Atzīmējiet daudzumu, ņemot vērā ēdiena bukleta datus.

24.1. Olīvellia

24.2. Rapšu ellıa

24.3. Eḷla cepšanai (kukurūzas, saulespuķu, sojas)

24.4. El़la un etiķis

24.5. Bez taukiem

24.6. Sinepes

24.7. Krējums

24.8. Majonēze

24.8.1. Parastā

24.8.2. Ar samazinātu tauku saturu

24.9. Nezinu

25. Tauku veids, ko izmantojat pie gaḷas, zivīm. Atzīmējiet daudzumu, ņemot vērā ēdiena bukleta datus:

25.1. Krējuma mērce

25.2. Krējums

25.3. Majonēze

25.3.1. Parastā

25.3.2. Ar samazinātu tauku saturu

25.4. Sinepes

25.5. Mārrutki

25.6. Kečups 
25.7. Tomātu mērces

25.8. Nezina

26. Cik stipri apceptu galıu parasti lietojat?

26.1. Līdz galam neapcepta

26.2. Vidēji apcepta

26.3. Stipri apcepta/pārcepta

27. Vai eddat vistu vai tītaru?

27.1. $\mathrm{Ne}$

27.2. Jā.

Kad ēdat vistu vai tītaru, cik bieži êdat ādu?

27.2.1. Gandrīz vienmēr

27.2.2. Bieži

27.2.3. Dažreiz

27.2.4. Reti

27.2.5. Nekad

28. Vai ēdat cūkgaļu, liellopa gaļu vai jēru?

28.1. Nē

28.2. Jā

Kad ēdat cūkgaļu, liellopa gaļu vai jēru, cik treknu gạıu lietojat?

28.2.1. Liesu

28.2.2. Ar tauku piedevu, cauraugušu

28.2.3. Treknu

29. Kad ēdat cūkgaļu, kādā veidā tā tiek lietota?

29.1. Sautēta

29.2. Cepta

29.3. Panēta (latviešu karbonāde)

30. Vai lietojat pienu ar putrām u.c. graudaugiem (brokastu pārslām)?

30.1. Nē

30.2. Jā

Kad lietojat pienu ar putrām u.c. graudaugiem (brokastu pārslām),

kāds piens tas parasti ir?

Atzīmējiet vienu vai divus.

30.2.1. $\leq 0,5 \%$ tauku

30.2.2. $0,6-2,5 \%$ tauku

30.2.3. $>2,6 \%$ tauku

31. Kad lietojat skābpiena produktus (paniņas, kefìru, rjaženku), kādu veidu parasti izvēlaties?

31.1. $\leq 0,5 \%$ tauku

31.2. $0,6-2,5 \%$ tauku

31.3. $>2,6 \%$ tauku

32. Kad ēdat biezpienu, kādu tauku \% parasti izvēlaties?

32.1. $\leq 0,5 \%$ tauku

32.2. $5 \%$ tauku

32.3. $9 \%$ tauku

33. Kad ēdat sieru vai kausēto sieru, kādu tauku \% parasti izvēlaties?

33.1. $\leq 30 \%$ tauku

33.2. $40-50 \%$ tauku 
5.pielikums

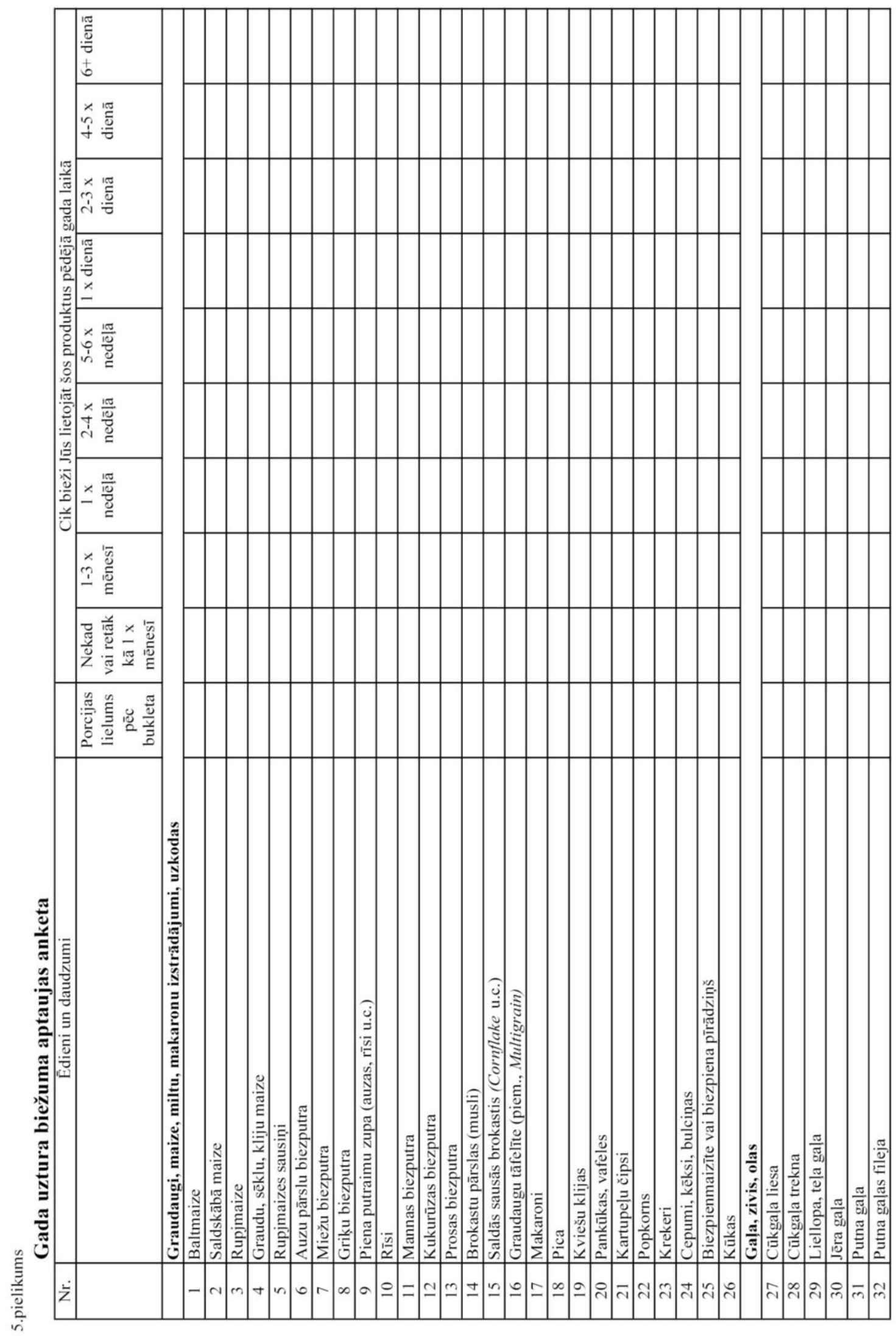




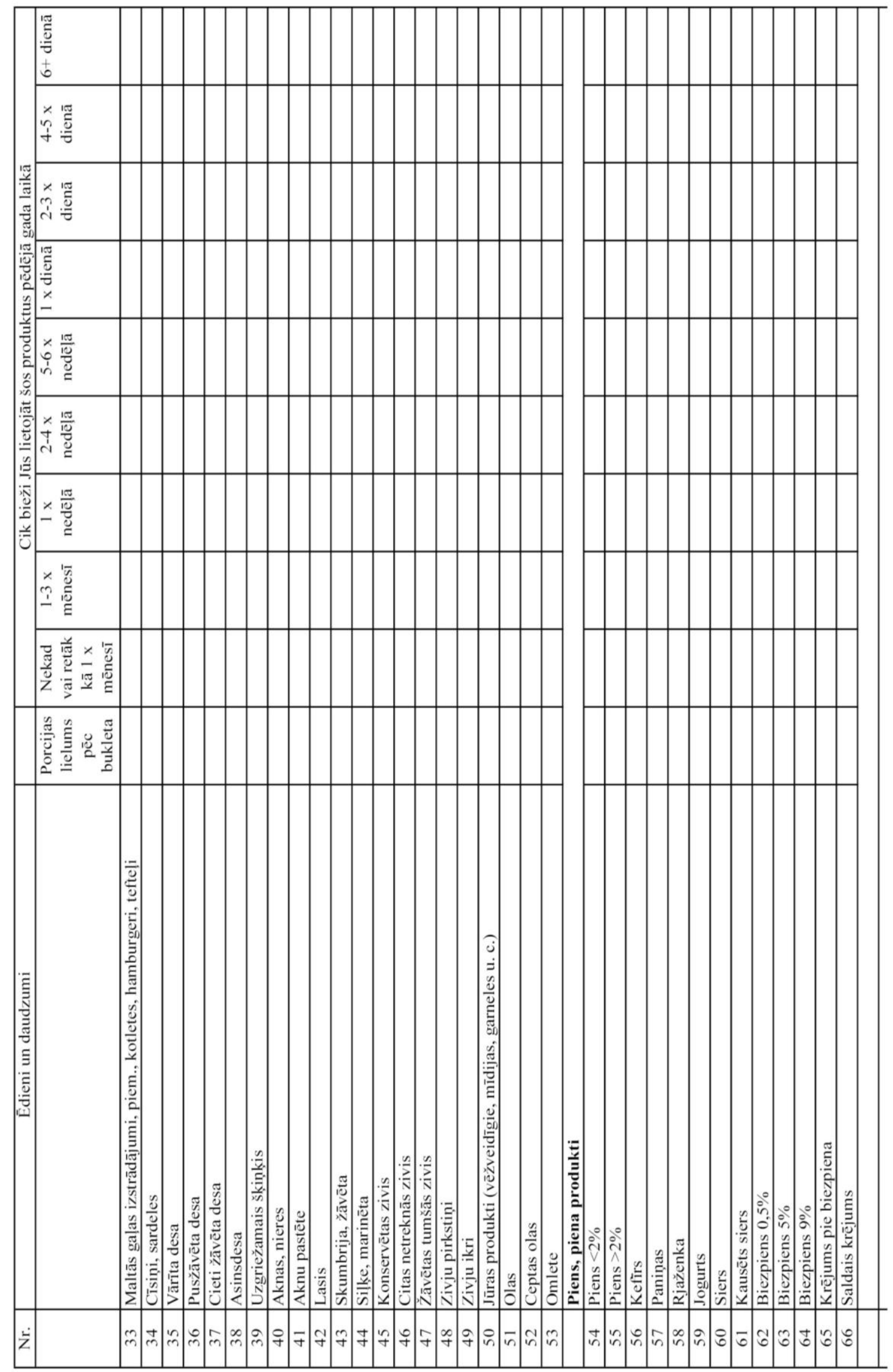




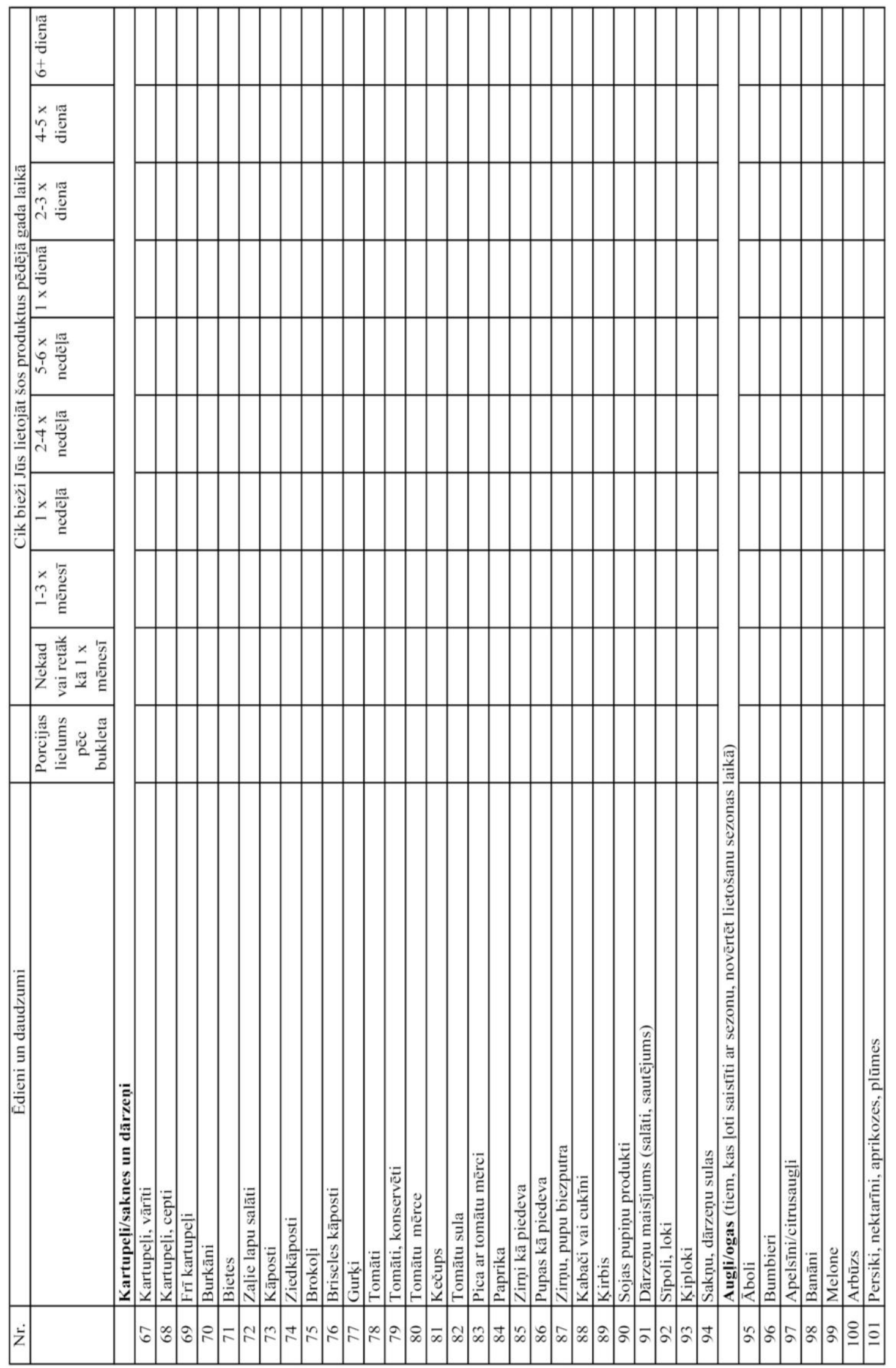




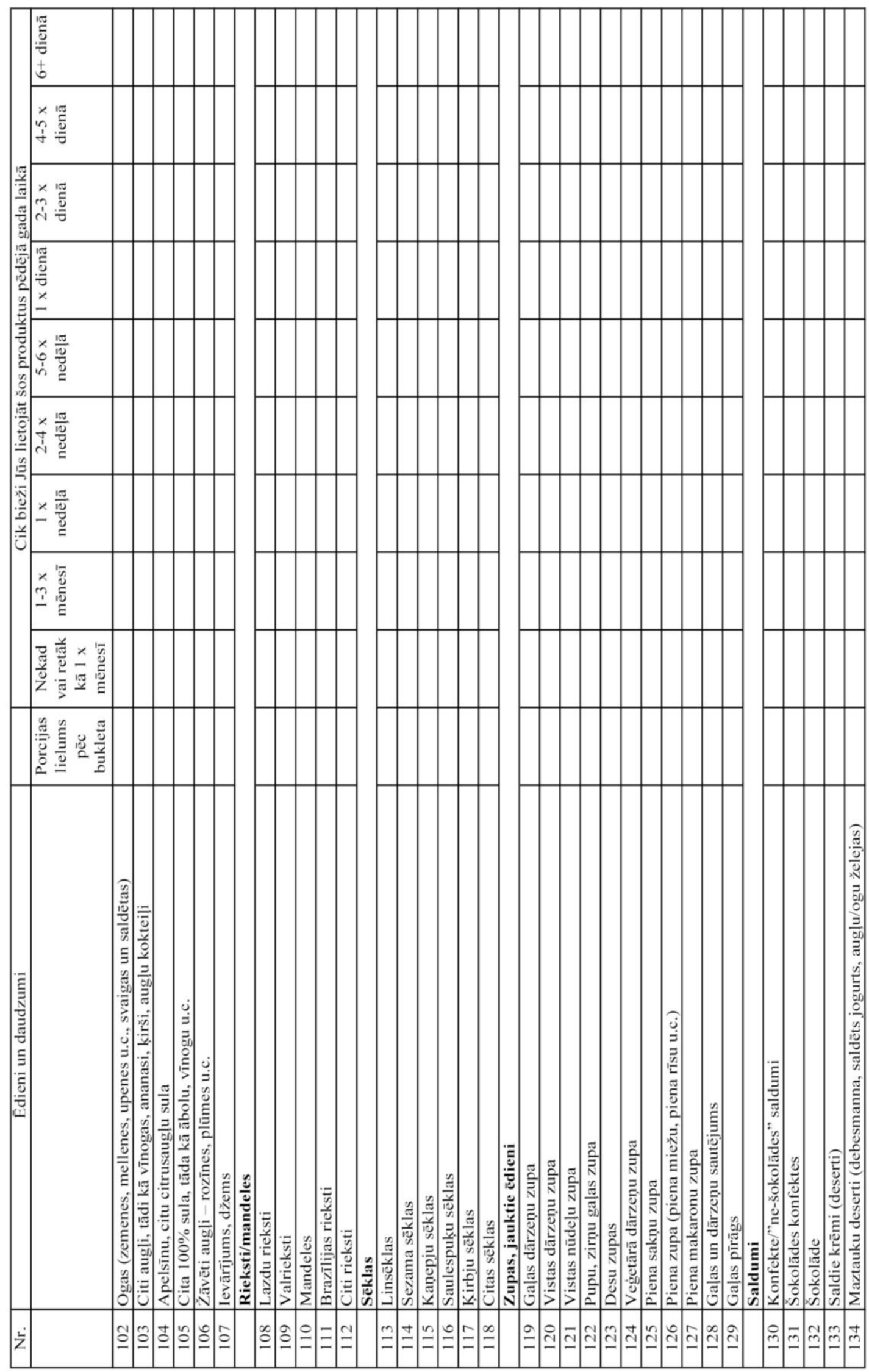




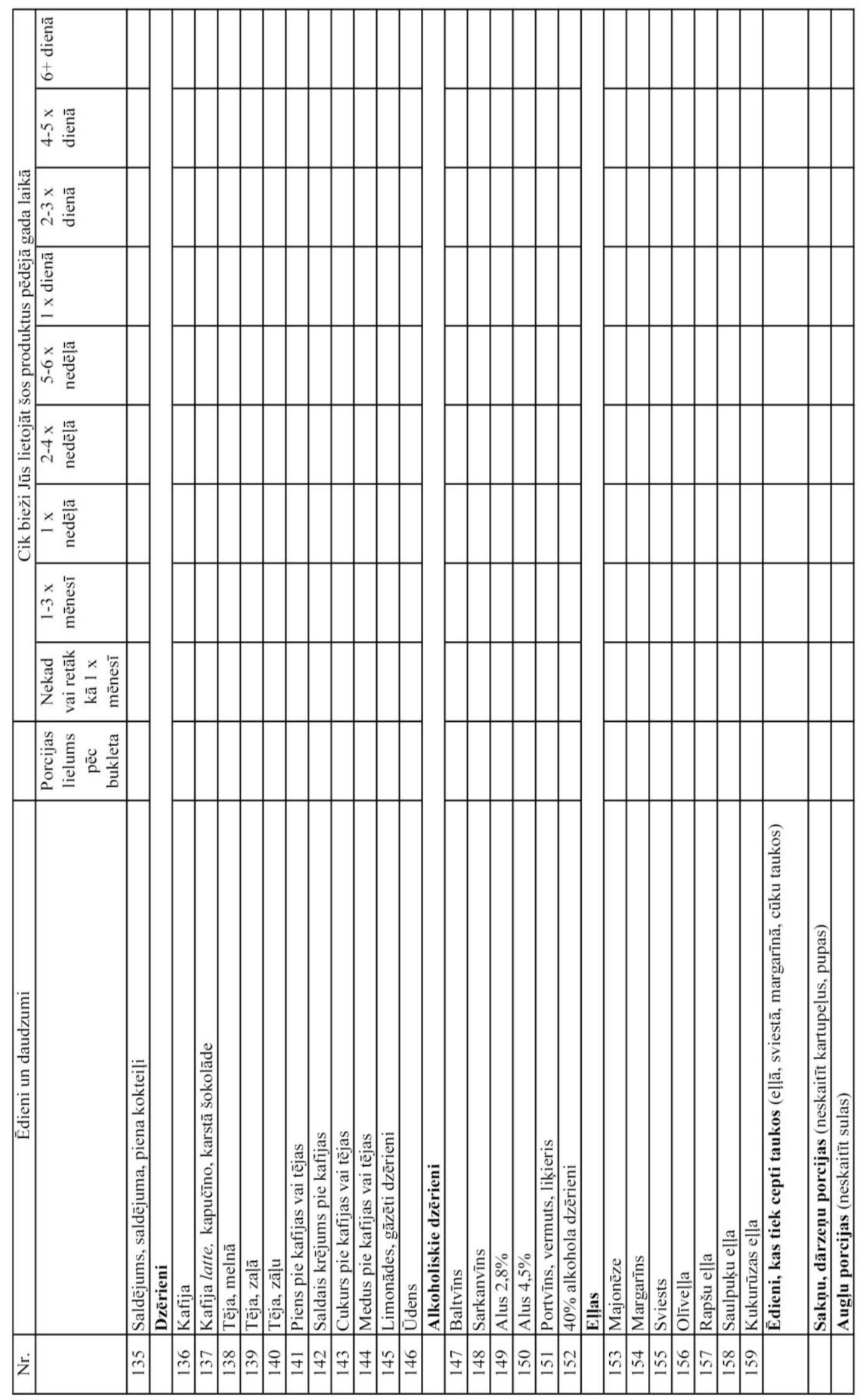


Uztura dienasgrāmata. 1 . diena. Datums:

\begin{tabular}{|c|c|}
\hline $\begin{array}{l}\text { Laiks (plkst.). Vieta (mājās, darbā, ciemos, } \\
\text { kafejnīcā u.c.) } \\
\text { Produktu/ēdienu/dzērienu saraksts. } \\
\text { Kā gatavots (cepts, vārīts, sautēts), piedevas }\end{array}$ & $\begin{array}{l}\text { Apēstais daudzums } \\
\text { (karotes, glāzes, ml, g) } \\
\text { vai svars pēc bukleta }\end{array}$ \\
\hline Brokastis. & \\
\hline Uzkodas & \\
\hline Pusdienas: & \\
\hline Launags & \\
\hline Vakariņas: & \\
\hline Uzkodas: & \\
\hline
\end{tabular}

Medikamenti, kas lietoti. Nosaukums, deva.

Pašsajūta (veselība)

Komentāri 


\section{Дневник питания}

1 день. Дата :

\begin{tabular}{|l|l|}
\hline $\begin{array}{l}\text { Время (часы). Место(дома, на работе, в гостях, в } \\
\text { кафе и др.) } \\
\text { Список еды/продуктов/напитков. } \\
\begin{array}{l}\text { Способ приготовления(жареное, } \\
\text { варёное,тушёное), гарнир }\end{array}\end{array}$ & $\begin{array}{l}\text { Объём съеденного( в } \\
\text { ложках, стаканах и т.д.) } \\
\text { Или по весу в } \\
\text { соответствии с буклетом }\end{array}$ \\
\hline Завтрак. & \\
\hline Закуски: & \\
\hline Обед: & \\
\hline Послеобеденный чай: & \\
\hline Ужин: & \\
\hline Закуски: & \\
\hline
\end{tabular}

Употребляемые медикаменты. Название, доза

Самочувствие (здоровье)

Комментарии 


\section{Cienījamais pētījuma dalībniek!}

Paldies, ka esat piekritis piedalīties pētìjumā par pilngraudu labvēlīgo ietekmi uz priekšdziedzera audzēju. Pilngraudi ir graudi, kuriem pārstrādes procesā nav atdalīts grauda apvalks. Tajā atrodas cilvēku hormoniem līdzīgas vielas - fitoestrogēni, kā arī citas vērtīgas bioloǵiski aktīvas vielas. Šìs vielas iedarbojas uz vēža šūnām, iespējams, nomācot to augšanu un attīstību.

Pārliecinošos zinātniskos pētîjumos ir pierādīts, ka Āzijas valstīs, kur uzturā iedzīvotāji lieto daudz vairāk fitoestrogēnu, vīriešiem ir daudz mazāka mirstība no priekšdziedzera vēža. Tāpēc priekšdziedzera vēža gadījumā ir l̦oti svarīgi lietot piemērotu uzturu.

Latvijas Valsts Stendes graudaugu selekcijas institūts ir radījis jaunas, īpaši vērtīgas graudu šķirnes. Lai izpētītu šo graudu iespējami labvēlīgo ietekmi uz cilvēka veselību, tika organizēts šis pētījums. Tas sastāv no diviem etapiem:

1) divas nedēḷas jāēd tikai baltmaize (visu pārējo Jūs varat ēst, kā esat paradis);

2) sešas nedēḷas jāēd tikai Stendes selekcionēto graudu maize (visu pārējo Jūs varat ēst kā parasti).

Pirms un pēc maizes lietošanas Jums tiks paņemtas asins analīzes, pēc kuru rezultātiem varēs novērtēt Stendes graudu ietekmi uz priekšdziedzera audzēju.

\section{! Uzman̄̄bu! Pētījuma laikā nedrīkst lietot antibiotikas. \\ Tas varētu negatīvi ietekmēt pētījuma rezultātus.}

Maizi (gan baltmaizi, gan Stendes pilngraudu maizi) Jums izdalīs gan analīžu noņemšanas laikā, gan turpmāk reizi nedēḷā norunātajā vietā netālu no Jūsu mājām, kur Jūs to varēsiet saṇemt.

Jebkuru neskaidrību gadījumā, lūdzu, zvaniet pa tālruni 26169142 Dainai Erdmanei.

\section{Pateicamies par piedalǐšanos!}




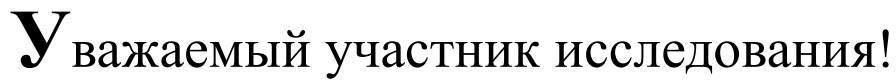

Спасибо, что вы согласились участвовать в исследовании по влияниюупотребления цельнозерновых продуктов на опухоль предстательной железы. Цельнозерновые продукты -это зёрна, у которых в процессе обработки не отделена оболочка зерна. В ней находятся вещества, схожие с гормонами человека фитоэстрогены, а также другие биологически активные вещества. Эти вещества воздействуют на клетки опухоли, скорее всего подавляя их рост и развитие.

В достоверных научных исследованиях доказано, что в странах Азии, где жители в рацион питания употребляют гораздо больше фитоэстрогенов, смертность у мужчин от рака предстательной железы намного меньше. Поэтому, в случае заболевания раком предстательной железы очень важно употреблять подходящую пищу.

Латвийский Государственный Стэндский Институт селекции зерновых создал новые, особо ценные зерновые сорта. Это исследование организовано для того, чтобы исследовать скорее всего благоприятное воздействие употребления в питании этих зёрен на здоровье человека. Исследование состоит из двух этапов:

1) В течение двух недель надо употреблять только белый хлеб (все остальные продукты Вы можете кушать как обычно);

2) В течение шести недель надо кушать только Стэндский зерновой хлеб (все остальные продукты Вы можете кушать как обычно).

Перед и после употребления хлеба, у Вас возьмут анализы крови, по результатам которых можно будет судить о влиянии употребления Стэндских зёрен на опухоль предстательной железы.

\section{!Внимание! Во время исследования нельзя употреблять антибиотики!}

Это может негативно повлиять на результаты исследования.

Хлеб (как белый, так и Стэндский зерновой) Вы получите во время сдачи анализов, после этого один раз в неделю, по договорённости, в месте недалеко от Вашего места жительства.

Если у вас возникли какие-либо вопросы, прошу звонить по телефону 26169142 , Дайна Ердмане.

Благодарим за участие! 


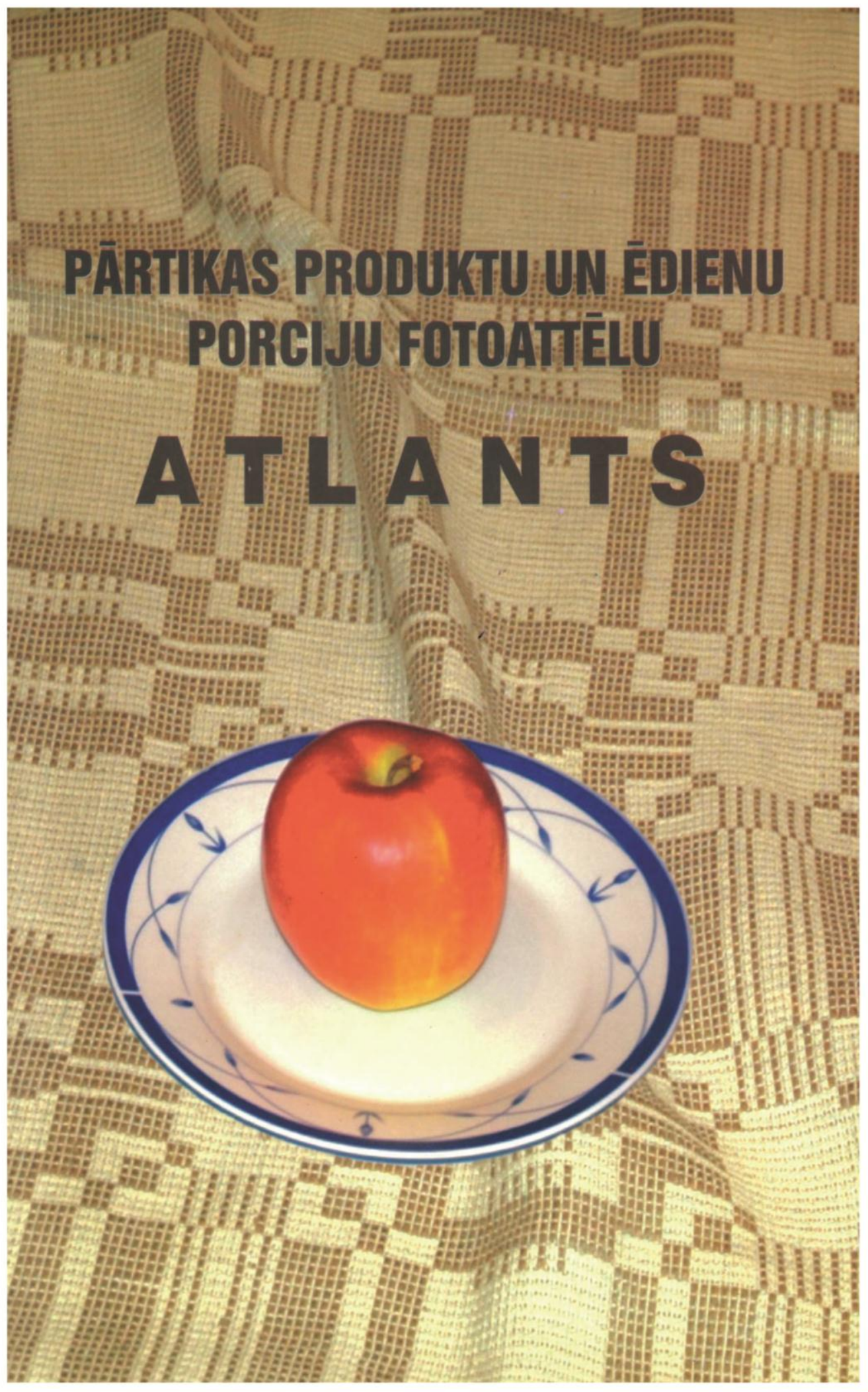




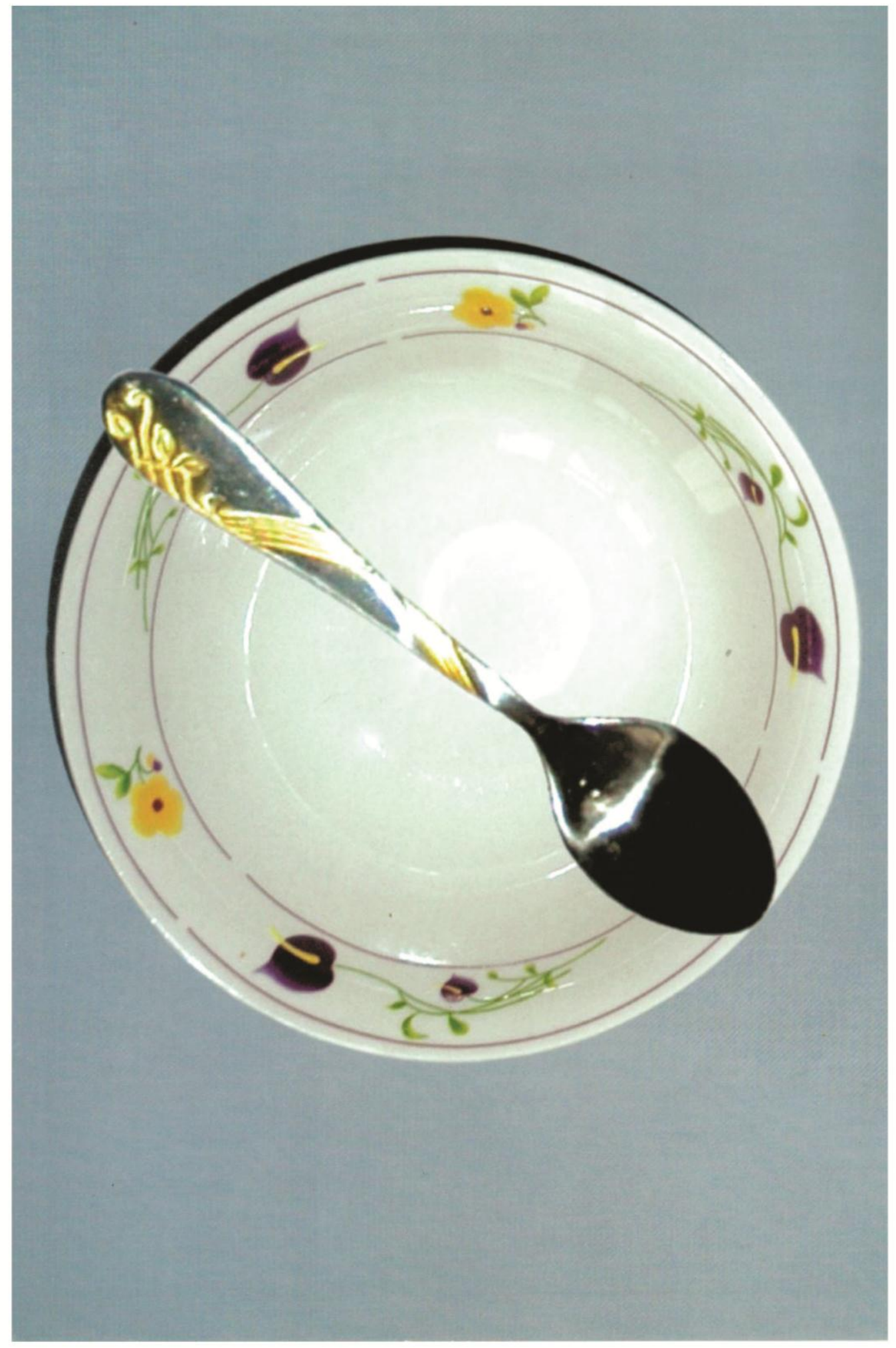



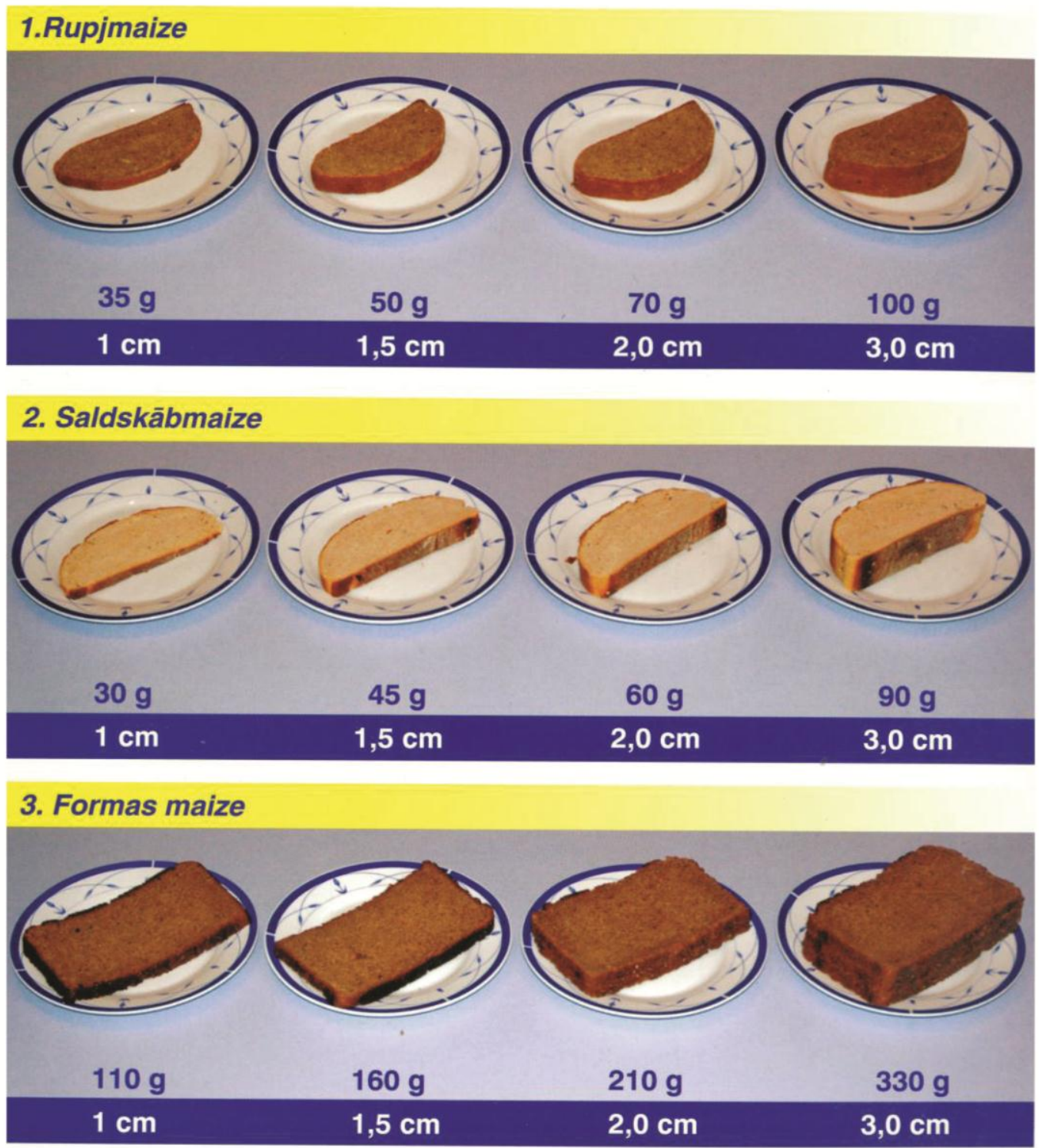

\section{Rupjmaize ar graudiem}

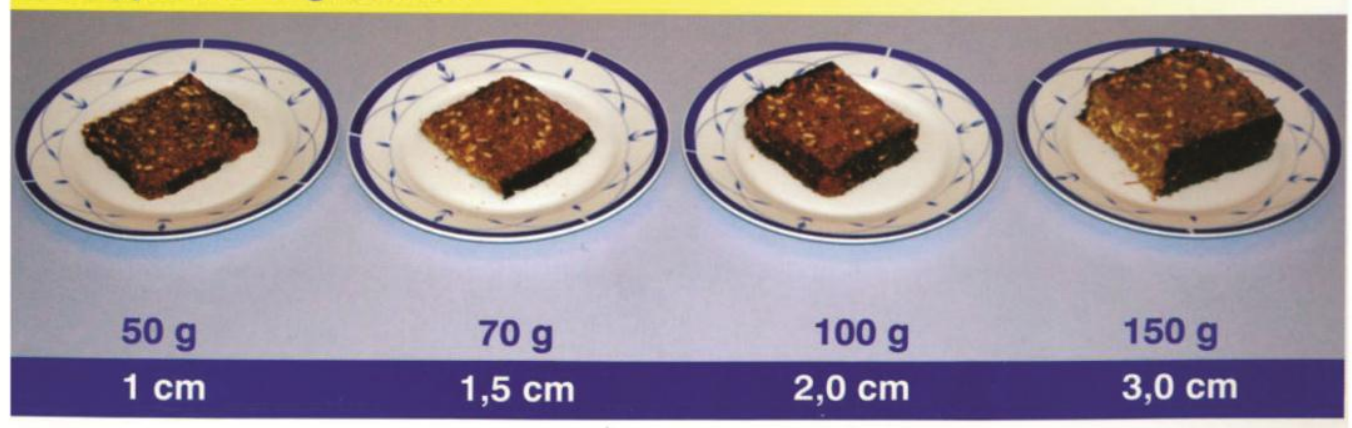


9. pielikums

\section{Informācija pacientam, aizpildot uztura dienasgrāmatu}

Paldies, ka piekritāt piedalīties pētījumā un aizpildīt sava uztura dienasgrāmatu. Vēlams šajās 3 dienās un īpaši 3. dienā, kad tiek vākts urīns, nelietot nekādus uztura bagātinātājus, vitamīnus, minerālvielas.

Ēšanas ieradumi nav jāmaina, ēdiet kā parasti - ierastos laikos un ierastos ēdienus. Noteikti pierakstiet pilnīgi visu, ko apēdat un izdzerat, pēc iespējas precīzi.

Ēdienu daudzumu novērtējiet, izmantojot „Pārtikas porciju un ēdienu porciju fotoattēlu atlantu" (turpmāk ēdienu atlants), vai norādiet produkta daudzumu karotēs (tējkarote, deserta karote, ēdamkarote), krūzēs. Ja precīzi zināms ēdiena daudzums gramos (piem., $100 \mathrm{~g}$ biezpiena), mililitros, litros (0,5 1 kvasa), tad atlants nav jāizmanto.

Pēc iespējas precīzi norādiet pārtikas produkta veidu, piem., rupjmaize, kliju maize, cieti žāvēta desa.

İpaši precīzi aprakstiet graudaugus - kāda veida maize, vēlams, norādot nosaukumu, vai pievienotas sēklas, klijas, graudi; kāda veida biezputras (ātri vārāmās vai pilngraudu), kādas brokastu pārslas lietotas.

Neaizmirstiet minēt riekstus, žāvētus aug̣̦lus, pupas, zirṇus.

Piena produktiem norādiet tauku saturu \%, piem., 2,5\% piens, 25\% krējums, sieram norādiet arī nosaukumu, piem., Holandes, Mālpils.

Aprakstot zupas, jānorāda, kāda gaļa izmantota un pamata sastāvdaļas, piem., pupiṇu zupa ar cūkgal̦as ribiṇām un kartupel̦iem, jānorāda arī, vai un cik daudz tiek pievienots krējums.

Aprakstot gaļas vai zivju ēdienus, jānorāda gaļas vai zivs veids, maltās gaļas izstrādājuma veids un taukvielas, kurās ēdiens tiek gatavots (piem., cūkas karbonāde,

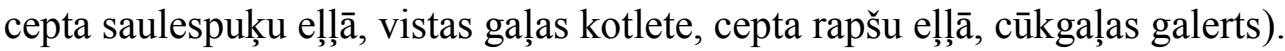

Biezputrām jānorāda, vai gatavotas pienā vai ūden̄̄, vai tiek pievienots sviests, cukurs, ievārījums.

Makaronu ēdieniem jānorāda, vai tiek pievienotas taukvielas.

Miltu, biezpiena ēdieniem, ja iespējams, norādiet sastāvdaḷas (piem., plānās pankūkas - kviešu milti, piens, olas, norādiet, piem., biezpiena sacepuma sastāvdal̦as). krējumu).

Salātiem norādiet sastāvdaḷas un izmantoto tauku veidu (piem., tomātu salāti ar

Norādiet arī visus dzērienus, vai tējai, kafijai pievienots cukurs, piens, saldais krējums un cik daudz pievienots. Norādiet arī izdzertā alkohola veidu un daudzumu. 


\section{2. Информация для пациента,}

\section{заполняющего дневник питания}

Спасибо, что согласились принять участие в исследовании и заполнить свой дневник питания. Желательно, в эти 3 дня, и,особенно, 3 дня пока будет браться моча, не употреблять никаких пищевых добавок, витаминов и минеральных веществ.Менять привычки питания не надо, питайтесь как обычно - в привычное время и привычные продукты.

Обязательно записывайте всё, что едите и пьёте и как можно точнее.

Количество съеденного оценивайте при помощи „Атласа фотоизображений порций продуктов и порций блюд” (в дальнейшем, атлас порций) или укажите количество продукта, измеренного ложкой (чайной, десертной, столовой) или кружкой. Если точно известно количество порции в граммах (например, 100 г. Творога), миллиграммах или литрах (0,5 л. кваса), то атлас использовать не надо.

По возможности точно укажите группу продукта, например, ржаной хлеб, отруби, копчёная колбаса.

Особо точно опишите зерновые продукты - из какого зерна сделан хлеб, желательно название, добавлены ли семечки, отруби, зерна; вид каш (быстрого приготовления или цельно-зерновые), какие хлопья, предназначенные для завтрака, вы употребляете.

Не забудьте упомянуть про орехи, сухофрукты, бобы и горох.

У молочных продуктов укажите содержание жира в \%, например 2,5\% молоко, 25\% сметана, а у сыра - название, например, Голландский, Малпилский.

Описывая супы, нужно указать, какое мясо было использовано и основной состав, например: фасолевый суп со свиными рёбрышками и картошкой, а также нужно указать, сколько добавили сметаны.

Описывая мясные и рыбные блюда нужно указать вид мяса и рыбы, вид продукта, приготовленного из фарша; и жиры на которых готовите (например: свиная отбивная, приготовленная на подсолнечном масле, куриные котлеты, приготовленные на рапсовом масле, свиной галет).

Для каш нужно указывать готовили на молоке или на воде, добавляли масло, сахар, варенье или нет.

Для макаронных блюд надо указать добавляли жиры или нет.

Для мучных, творожных блюд, если возможно, укажите состав (например, тонкие блины - пшеничная мука, молоко, яйца; и укажите, например, состав творожной массы).

Для салатов укажите состав и используемые жиры (например, помидорный салат со сметаной).

А также укажите все напитки; добавляете ли сахар, молоко, сливки в чай и кофе и сколько. Укажите вид и количество употребляемого алкоголя. 
10. pielikums

\section{Informācija pacientam, aizpildot uztura dienasgrāmatu}

Paldies, ka piekritāt piedalīties pētījumā un aizpildīt sava 3 dienu uztura dienasgrāmatu. Éšanas ieradumi nav jāmaina, ēdiet kā parasti - ierastos laikos un ierastos èdienus. Aizpildot uztura dienasgrāmatu (3 dienas pirms pētījuma beigām), lūdzu, ierakstiet arī apēstās pētījuma maizes daudzumu.

\section{Lūdzu, ņemiet vērā, ka pētījuma laikā jāizslēdz cita veida maizes vai pilngraudaugu produktu lietošana! \\ Noteikti pierakstiet pilnīgi visu, ko apēdat un izdzerat, pēc iespējas precīzi.}

Ēdienu daudzumu novērtējiet, izmantojot „Pārtikas porciju un ēdienu porciju fotoattēlu atlantu" (turpmāk ēdienu atlants), vai norādiet produkta daudzumu karotēs (tējkarote, deserta karote, ēdamkarote), krūzēs. Ja precīzi zināms ēdiena daudzums gramos (piem., $100 \mathrm{~g}$ biezpiena), mililitros, litros (0,5 $1 \mathrm{kvasa})$, tad atlants nav jāizmanto.

Pēc iespējas precīzi norādiet pārtikas produkta veidu, piem., rupjmaize, kliju maize, cieti žāvēta desa.

İpaši precīzi aprakstiet, kāda veida biezputras, kādas brokastu pārslas lietotas.

Neaizmirstiet minēt riekstus, žāvētus augḷus, pupas, zirṇus.

Piena produktiem norādiet tauku saturu \%, piem., 2,5\% piens, 25\% krējums, sieram norādiet arī nosaukumu, piem., Holandes, Mālpils.

Aprakstot zupas, jānorāda, kāda gal̦a izmantota, un pamata sastāvdaļas, piem., pupiṇu zupa ar cūkgal̦as ribiṇām un kartupeḷiem, jānorāda arī, vai un cik daudz tiek pievienots krējums.

Aprakstot gaļas vai zivju èdienus, jānorāda gaḷas vai zivs veids, maltās gaļas izstrādājuma veids un taukvielas, kurās ēdiens tiek gatavots (piem., cūkas karbonāde, cepta saulespuķu eḷıā, vistas gaḷas kotlete, cepta rapšu eḷıāa cūkgaļas galerts).

Biezputrām jānorāda, vai gatavotas pienā vai ūden̄̄, vai tiek pievienots sviests, cukurs, ievārījums.

Makaronu ēdieniem jānorāda, vai tiek pievienotas taukvielas.

Miltu, biezpiena ēdieniem, ja iespējams, norādiet sastāvdaḷas (piem., plānās pankūkas - kviešu milti, piens, olas, norādiet, piem., biezpiena sacepuma sastāvdaļas).

Salātiem norādiet sastāvdaḷas un izmantoto tauku veidu (piem., tomātu salāti ar krējumu).

Norādiet arī visus dzērienus, vai tējai, kafijai pievienots cukurs, piens, saldais krējums un cik daudz pievienots. Norādiet arī izdzertā alkohola veidu un daudzumu. 


\section{2. Информация для пациента, заполняющего дневник питания.}

Спасибо, что согласились принять участие в исследовании и заполнить свой дневник питания.

Менять привычки питания не надо, питайтесь, как обычно - в привычное время и привычные продукты.

Обязательно записывайте всё, что едите и пьёте, и как можно точнее.

Количество съеденного оценивайте при помощи „Атласа фотоизображений порций продуктов и порций блюд” (а в дальнейшем, атлас) или укажите количество продукта, измеренного ложкой (чайной, десертной, столовой) или кружкой. Если точно известно количество порции в граммах (например, 100 г. творога), миллиграммах или литрах (0,5 л. кваса), то атлас использовать не надо.

По возможности точно укажите группу продукта, например: ржаной хлеб, отруби, копчёная колбаса.

Особо точно опишите вид употребляемых Вами каш и хлопьев, которые Вы кушаете на завтрак.

Пожалуйста, обратите внимание на то, что во время исследования Вы должны исключить из рациона питания другие виды хлеба или цельнозерновые продукты!

Не забудьте упомянуть также цельнозерновой хлеб, который Вы получаете еженедельно!

Не забудьте упомянуть про орехи, сухофрукты, бобы и горох.

У молочных продуктов укажите содержание жира в \%, например 2,5\% молоко, 25\% сметана, а у сыра - название, например, Голландский, Малпилский и т.д.

Описывая супы, нужно указать, какое мясо было использовано и основной состав, например фасолевый суп со свиными рёбрышками и картошкой, а также нужно указать, сколько добавили сметаны.

Описывая мясные и рыбные блюда нужно указать вид мяса и рыбы, вид продукта, изготовленного из фарша, и жиры на которых готовите (например, свиная отбивная, приготовленная на подсолнечном масле; куриные котлеты, приготовленные на рапсовом масле; свиной галет).

Для каш нужно указывать готовили их на молоке или на воде, добавляли ли масло, сахар, варенье или нет.

Для макаронных блюд надо указать добавляли жиры или нет.

Для мучных, творожных блюд, если возможно, укажите состав (например: тонкие блины - пшеничная мука, молоко, яйца; и укажите, например, состав творожной массы).

Для салатов укажите состав и используемые жиры (например, помидорный салат со сметаной).

А также укажите все напитки; добавляете ли сахар, молоко, сливки в чай и кофе и в каком количестве. Укажите вид и количество употребляемого алкоголя. 
11. pielikums

\section{Instrukcijas pētniekiem un laboratorijas darbiniekiem \\ 24 stundu urīna savākšanas uzraudzības un glabāšanas instrukcija}

\section{Urīna konteineru sagatavošana laboratorijāa}

- Nomarķēe konteinerus urīnam, D - diena, N - nakts.

- Iesver $1 \mathrm{~g}$ askorbīnskābes katrā konteinerā (dienas un nakts urīna konteinerā).

\section{Uzdevumi pētniekam:}

- Vienam pētījuma dalībniekam iedod divus 21 traukus (dienas un nakts urīnam).

- Pētījuma dalībniekam iedod 24 stundu urīna savākšanas instrukciju. Jāpārliecinās, vai pētījuma dalībnieks ir pilnībā izpratis viṇam iedoto instrukciju. Ja nav, jāpaskaidro viņam saprotamā veidā.

- Kad dalībnieks nodod abus urīna traukus, tie jāglabā ledusskapī $\left(4{ }^{\circ} \mathrm{C}\right.$ temperatūrā).

\section{Laboratorijā}

- Nomarķē kriostobriņus, divus dienas urīnam, divus - nakts. Nakts urīna kriostobriņiem liek sarkanu vāciņu.

- No katra urīna konteinera ielej 4,5 ml urīna kriostobriņos (attiecīgi dienas un nakts).

- Kriostobriņus ievieto saldētavā $-20{ }^{\circ} \mathrm{C}$

- Nomēra urīna tilpumu atsevišķi dienas un nakts urīnam, lietojot mērcilindru un neaizmirstot pieskaitît 2 x 4,5 ml, kas jau ielieti kriostobrinos.

- Nodotajam urīnam jāatzīmē urīna savākšanas sākuma un beigu laiks un dienas un nakts urīna tilpums speciālā veidlapā.

\section{Asins paraugu savākšanas un glabāšanas instrukcija}

- Marķē 2 vakutainerus $10 \mathrm{ml}$.

- Pacientam jābūt tukšā dūšā. $10 \mathrm{ml}$ asinu tiek savākts 2 vakuuma heparīna stobriņos (10 ml katrā stobriņā), mēǵgenes tiek glabātas istabas temperatūrā līdz transportēšanai uz laboratoriju.

- Nogādā laboratorijā 2 stundu laikā no paņemšanas brīža.

- Nomarksēe divus kriostobriņus un iesver askorbīnskābi 4,5 mg katrā kriostobrin̄ā (1 mg/1 ml).

- Vakutainerus centrifugē 10 min 3000 apgriezieni/min $4 \mathrm{C}$ temperatūrā, atsūc plazmu (pa 4,5 ml) un salej kriostobriņos.

- Mēgenenes ievieto saldētavā $-20{ }^{\circ} \mathrm{C}$. 


\section{2 stundu dienas un 12 stundu nakts urīna savākšanas un glabāšanas instrukcija}

Jāsavāc pilnīgi viss diennakts urīns.

Urīna savākšana notiek 2 dạ̦ās:

Tiek izsniegtas divas 21 trauki.

Savāktais urīns jāglabā ledusskapja temperatūrā (līdz plus $\left.4{ }^{\circ} \mathrm{C}\right)$.

\section{Pirmais posms. Dienas urīns - 12 stundas}

Dienas sākumā tūlīt pēc pamošanās jāiztukšo urīnpūslis.

Urīnu sāk vākt no nākamās urinēšanas reizes. Jāatzīmē laiks (piem., plkst. 7.00; plkst. 8.00 vai plkst. 10.00)

Pirmā savāktā urīna porcija plkst.

Turpmāk pilnīgi viss urīns jâsavāc speciālajā šim nolūkam paredzētajā traukāa (jāurinē tikai speciālajā traukā). Katru reizi pēc urinēšanas traukā tas viegli jāsakrata.

Jābeidz pēc 12 stundām (piemēram, ja esat sācis plkst. 7.00 no rīta, tad pirmajā traukā jābeidz urinēt plkst. 19.00).

Jāpieraksta šis laiks

\section{Otrais posms. Nakts urīns -- 12 stundas}

Nākamās 12 stundas jāurinē otrā traukā.

Pieraksta pirmās nakts urīna porcijas laiku. Plkst.

Atkal pilnīgi viss urīns jāsavāc speciālajā šim nolūkam paredzētajā traukā (jāurinē tikai speciālajā traukā). Katru reizi pēc urinēšanas traukā tas viegli jāsakrata.

$\underline{\text { Pēdējā urīna porcija nākamajā rītā pēc pamošanās pirms brokastīm. }}$

Jāpieraksta šis laiks (pulkstenis) 


\section{Инструкция по 12 часовому дневному сбору мочи и 12 часовому ночному сбору мочи}

Необходимо собрать абсолютно всю суточную мочу.

Сбор мочи происходит в два этапа:

Выдаётся 2 литровых ёмкости.

Собранная моча должна храниться в холодильнике (при темрературе $+4^{\circ} \mathrm{C}$ ).

\section{Первый этап. 12 часовой дневной сбор мочи}

Утром, сразу после пробуждения опоржнить мочевой пузырь.

Мочу начинать собирать со следующего раза мочеиспускания. Надо отметить время (напр., 7.00; 8.00 или 10.00)

Первая порция мочи собрана в

В последующем полностью всю мочу необходимо собирать в отведённую ёмкость (необходимо мочиться только в специальную ёмкость). Каждый раз, после мочеиспускакния, посуду необходимо легко взболтать.

Закончить надо спустя 12 часов(например, если Вы начали в 7.00 утра, то Вы прекращаете собирать мочу в первую ёмкость в 19.00).

Необходимо записать это время

\section{Второй этап. 12 часовой ночной сбор мочи}

Последующие 12 часов необходимо мочиться во вторую ёмкость.

Запишите время первой порции мочеиспускания. Время

Опять в последующем полностью всю мочу необходимо собирать в отведённую ёмкость (необходимо мочиться только в специальную ёмкость). Каждый раз после мочеиспускакния, посуду необходимо легко взболтать.

Последняя порция мочи - это утром после пробуждения - перед завтраком.

Запишите это время (часы) 